\title{
A revision of the genus Leptospermum (Myrtaceae)
}

\author{
Joy Thompson
}

\begin{abstract}
Thompson, Joy (National Herbarium of New South Wales, Royal Botanic Gardens, Sydney, Australia 2000) 1988. A revision of the genus Leptospermum (Myrtaceae). Telopea 3(3): 301-449. The genus Leptospermum is revised and a new generic description provided. Generic attributes are discussed in relation to new observations and previous, often incorrect, descriptions in published work. A key to the 79 species accompanies a formal treatment of these taxa of which 27 are new, and 15 renamed or very much altered as to circumscription. Eight new subspecies are recognised. Seven putative natural groups are discussed; each in relation to its species-members, anomalies, the possibility of reticulation and its likely history. The evidence suggests that Leptospermum originated before the onset of Miocene aridity, and was dispersed relatively recently from eastern Australia to New Zealand, New Guinea, the Kimberley region of Western Australia and South East Asia.
\end{abstract}

Table of Contents

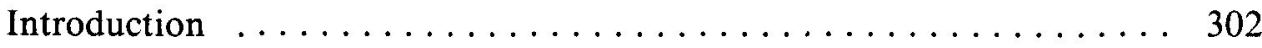

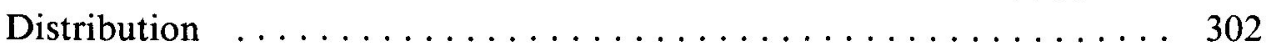

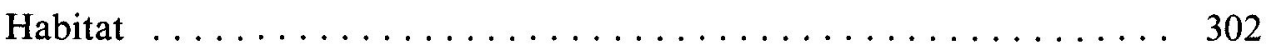

Diagnostic characters . . . . . . . . . . . . . . . . . . . . 304

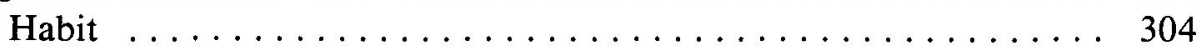

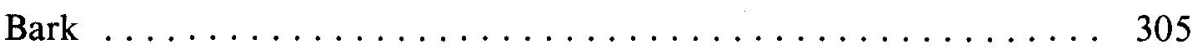

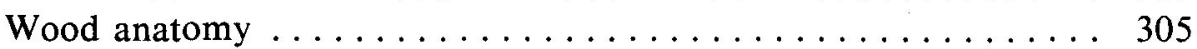

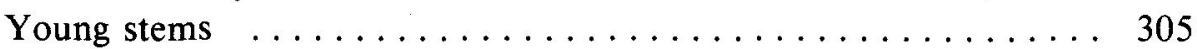

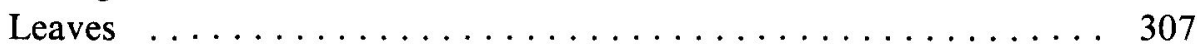

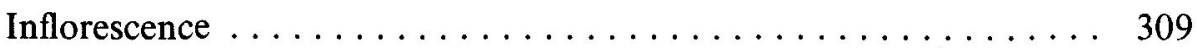

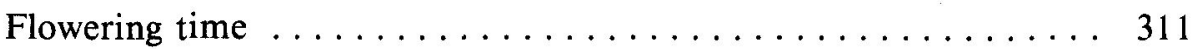

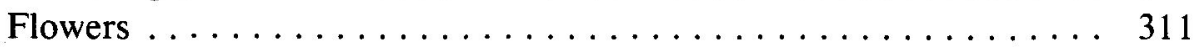

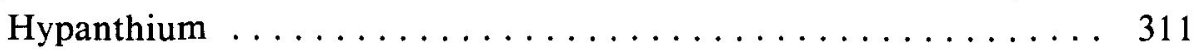

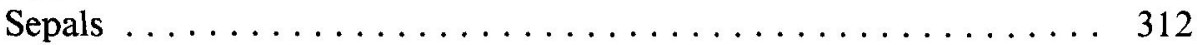

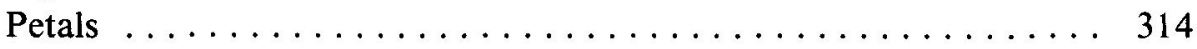

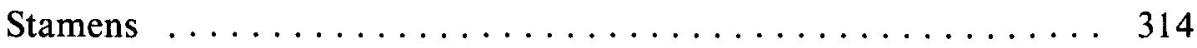

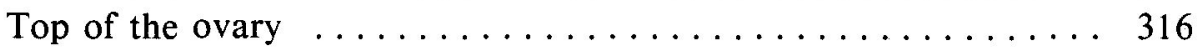

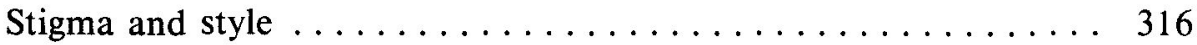

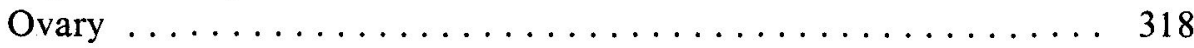

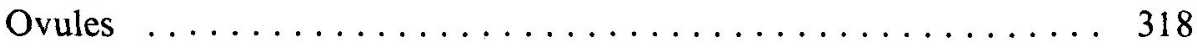

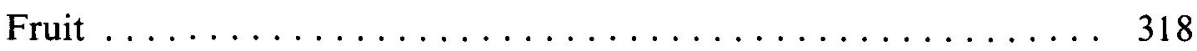

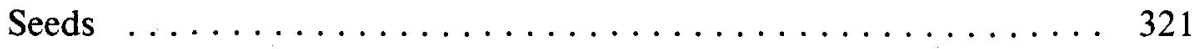

Chromosomes ........................ 323

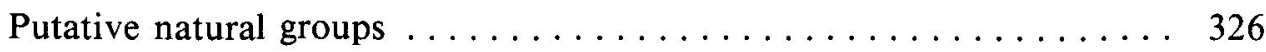

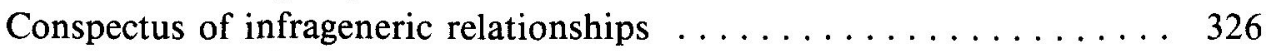

Evolution and dispersal $\ldots \ldots \ldots \ldots \ldots \ldots \ldots \ldots \ldots \ldots \ldots$ 
Generic description ........................... 339

Key to species .......................... 340

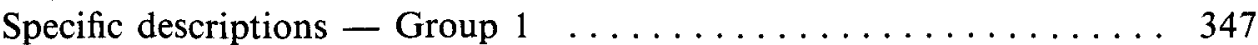

Specific descriptions - Group $2 \ldots \ldots \ldots \ldots \ldots \ldots \ldots \ldots \ldots \ldots$

Acknowledgements ........................ 443

References .............................. 444

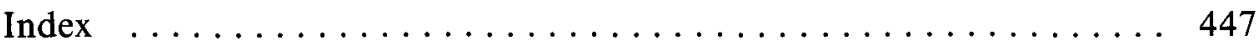

\section{Introduction}

The genus Leptospermum is a natural, but somewhat bipartite, taxon that has never been represented accurately as a whole in literature. Bentham (1867) included other genera in his concept. He also did not appreciate infrageneric relationships. As a result of this, and his failure to sustain genera and species distinguished by his predecessors, taxonomy in this area of the Myrtaceae has continued since Bentham's day in a state of chaos. The generic limits of Leptospermum have now been defined (Thompson 1983), and species of Kunzea, Homalospermum, Pericalymma and Neofabricia, formerly included, shown to be misplaced there. This redefinition has removed many of the anomalies that had brought confusion to the treatments of Leptospermum in most published work.

\section{Distribution}

Leptospermum is widely distributed across southern Australia. In eastern Australia Leptospermum is found from southern Tasmania to Cape York, while one species extends westward in the tropics to the Northern Territory and northwestern Australia and also across Torres Strait to New Guinea. One species common in Tasmania is widespread in New Zealand. Two species are found in South East Asia, one endemic on Mt Kinabalu in Borneo and the other, predominantly on mountains, from southern Burma, Thailand and the Philippines, to Flores and the Moluccas (see Map 1). The genus is not in the Caroline Islands, that record being based on L. benningsenianum, a species of Myrtella (Scott 1978), and is not in New Caledonia, though recorded by Curtis and Morris (1975) for that island. It has been recorded also for the mountains of New Guinea by Mueller (1890) and Diels (1922), but the descriptions given are obviously based on misidentified specimens.

\section{Habitat}

Though found in a variety of habitats, members of this genus are usually where the substrate is wet or periodically damp, and is acid with a low nutrient content. Mycorrhizae, both ectotrophic and endotrophic, have been found associated with the roots of a number of species (Lamont 1979). Habitats include damp sandy heath, areas of high water-table in dry sclerophyll forest, the base of granite boulders in arid Western Australia, crevices of granite boulders, coastal and inland dunes and sandstone escarpments, while soils range from the skeletal of rock outcrops to deep river sands. Some species occupy particular habitats; such as L. laevigatum, usually found on beach sand (Burrell 1981), L. riparium on river margins in Tasmanian rainforest (Jarman \& Brown 1983), and some local endemics (such as $L$. grandiflorum and $L$. 

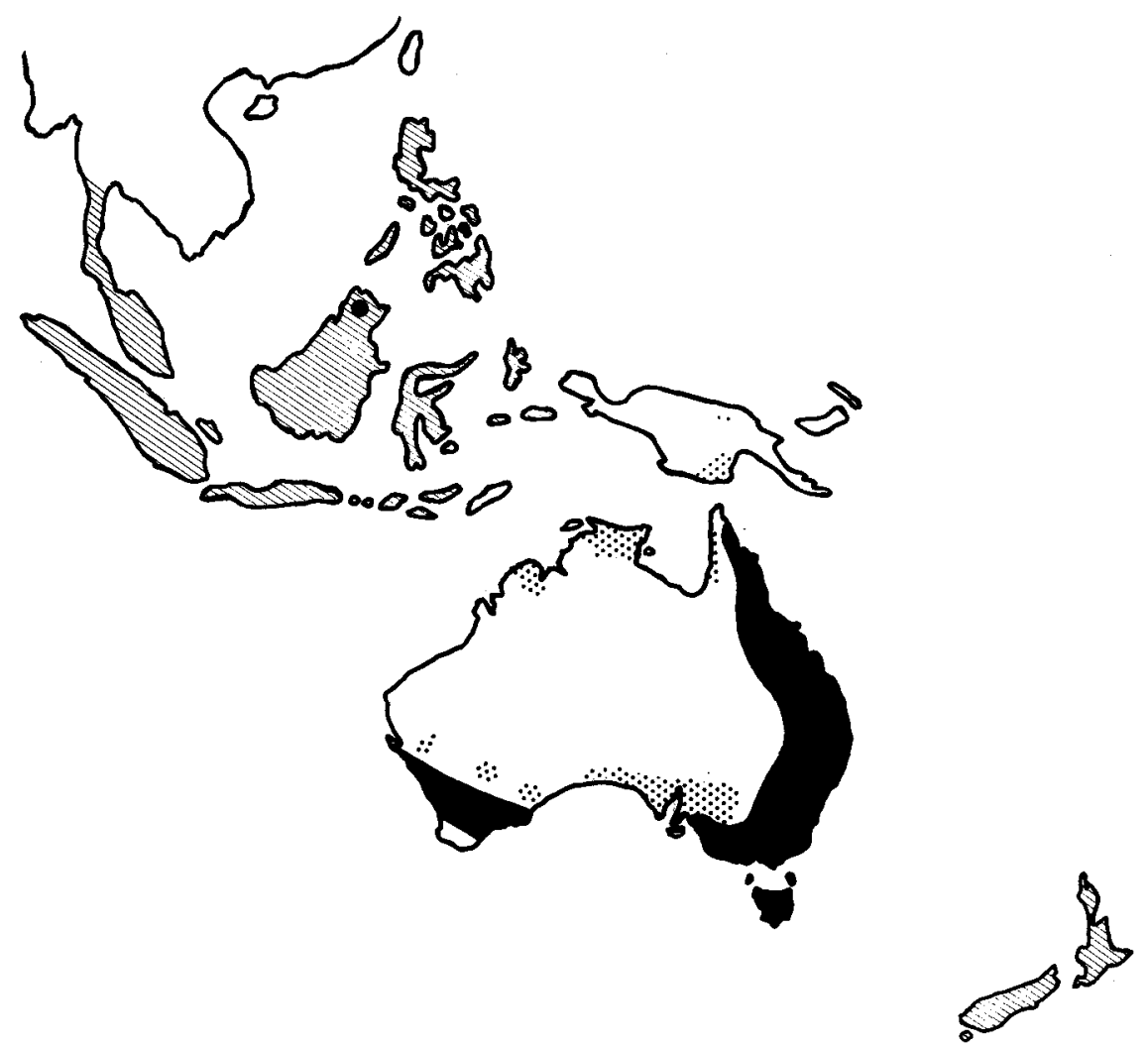

more than one species

one species (of Group 1)

one species (of Group 2) 
petraeum) on rocky sites. However, most species grow near and often intermingled with other species, making estimation of their particular habitatrequirements difficult. Morrison and Myerscough (1982) have distinguished the habitats of L. polygalifolium and L. morrisonii on the basis of soil-nutrients, but more work of this nature is needed to explain the distributions associated with soil-type that separate other closely related species such as L. trinervium and $L$. subglabratum, and members of the $L$. roei group in Western Australia. A number of species inhabit apparently similar environments, as with $L$. liversidgei, L. polygalifolium, L. speciosum, L. trinervium, $L$. whitei and $L$. semibaccatum on the coastal sands of northern New South Wales and southern Queensland, and L. polygalifolium, L. trinervium, L. myrtifolium, $L$. continentale and $L$. obovatum on infertile tableland soils of central eastern New South Wales. None of these species is a relict occupying a species-rich environment as suggested by Smith (1981); on the contrary, they are all wide-ranging and rather vigorous species. Many of the species show great altitudinal range. L. obovatum reaches almost to the treeline of subalpine Kosciusko but also occurs near the coast in East Gippsland and western Victoria. The two Tasmanian endemic species $L$. nitidum and $L$. glaucescens are similarly found in both high-mountain and coastal regions. The variation associated with broad altitudinal range has been studied by Lee and Lowry (1980) for $L$. javanicum and $L$. recurvum in Borneo, Burrell (1965) for L. scoparium in New Zealand and Morrison (1984) for L. polygalifolium and L. morrisonii in central eastern New South Wales. Morrison found that the two taxa differed in their degree of response to increasing altitude.

\section{Diagnostic characters}

\section{Habit}

Although some species, notably $L$. javanicum, can become tall forest trees and others are usually found as low-growing shrubs, most Leptospermum species vary greatly in size according to the opportunity presented to the individual by the habitat. The relatively large-boled tree, L. purpurascens, has been observed to flower (in the nursery of the Royal Botanic Gardens Sydney) at the height of $15 \mathrm{~cm}$. Most species readily reach a height of 1-2 metres but many of these have been reported as being found as trees in sheltered positions. Apart from size, most species have a characteristic habit, with the timing and vigour of the buds from the flowering region having great effect on the general aspect of the plant. Some species, such as $L$. brevipes, have a number of slender graceful young stems during or after flowering, while others, like L. juniperinum, are graceful in the upper part but leafless below. Others, like L. lanigerum and $L$. grandifolium, have their dense bushy nature assured by a moderate and uniform extension of growth from the terminal bud of many flowering shoots, each of which is at the end of a leafy axillary branchlet. The angle at which the majority of young stems branch from stems of a higher order is characteristic. The broad angle of branching found in species such as $L$. erubescens, $L$. exsertum, L. arachnoides and $L$. glabrescens, perhaps associated with the optimal display of flowers, is a useful diagnostic feature. Lignotubers have not been observed for many species but the "whipstick" nature of many is probably associated with an ability to shoot from a stout stock after trauma to the aboveground parts. L. myrsinoides is said (Burrell 1981) to regenerate from underground parts. The disproportionately stout trunks of $L$. trinervium are obviously associated with its possession of epicormic buds (protected by corky layered bark) ready to shoot after fire in its dry forest habitat. 


\section{Bark}

Several different bark-types are found among species of Leptospermum. In most species the bark is fibrous and remains close to the stem, though on older plants it may loosen at the base of the plant. This bark-type can be seen in $L$. polygalifolium and $L$. lanigerum (fig. 1a). L. petersonii has a loosely fibrous (stringy) bark (fig. $1 \mathrm{c}$ ), as do $L$. javanicum, $L$. recurvum and $L$. wooroonooran. L. brachyandrum, L. luehmannii (fig. 1e), L. parviflorum and L. purpurascens have bark that exfoliates seasonally to reveal a very smooth and often brightly coloured surface. L. grandifolium (fig. 1b) also sheds its bark in layers but these remain untidily about the stems. L. trinervium (fig. 1d) has bark in many fine layers with the outer layers being shed irregularly, whereas in L. macrocarpum, $L$. spectabile and $L$. sphaerocarpum a fibrous bark remains in place but becomes thick, dark and corrugated. Bamber (1962) examined the microscopic anatomy of the bark of several species of Leptospermum but there is no correlation between his anatomical results and the striking differences in external morphology, and this study did not distinguish taxa now assigned to Kunzea and Homalospermum. Aerenchymatous layers have been found in bark of $L$. scoparium under conditions of water-logging in New Zealand by Cook et al. (1980). It is possible that this feature could occur in other species, many of which flourish in flood-prone habitats and tend to have lifting bark at the base of their trunks.

\section{Wood Anatomy}

Wood structure of members of this family has been extensively studied, and wood characteristics have proved useful especially in the delimitation of genera. For instance, Van Wyk et al. (1983) found the wood of the southern African species of Eugenia quite distinct from that of Syzygium. But wood anatomists have suffered from the prevailing confusion as to the limits of Leptospermum. Ingle and Dadswell (1950) included Kunzea ericoides in the genus. Baas's (1977) Leptospermum was Pericalymma. Carlquist (1977) included the genera Homalospermum and Pericalymma in his concept of Leptospermum, while Johnson (1984) confused all these genera, and also Neofabricia. Only Johnson's work deals with individual Leptospermum species and it does not support apparently natural relationships, apart from the separation of Pericalymma.

\section{Young Stems}

It is the younger stems that are to be found in herbarium specimens, and characters from these can be useful for distinguishing species. On new growth, most species have long fine silky hairs that soon become sparse or are lost. Pubescence other than this is of taxonomic significance in some species although in most it is variable, especially as to the amount present and the proportions of different types, and cannot be used confidently for classification. These young stems often have a membranous flange extending each side of the leaf-base and sometimes continuing for some distance down the stem. In some species, such as L. javanicum (fig. 2a) this is very conspicuous and wing-like, while it is absent from others, like L. grandifolium (fig. 2b). In L. laevigatum (fig. 2c) a groove runs down the stem from beyond the leaf-base as if extra tissue has become fused (this needs confirmation by anatomical study), while, especially in Western Australian species (fig. 2d), there is an extension that remains on the stem as a conspicuous projection after leaf-fall. 


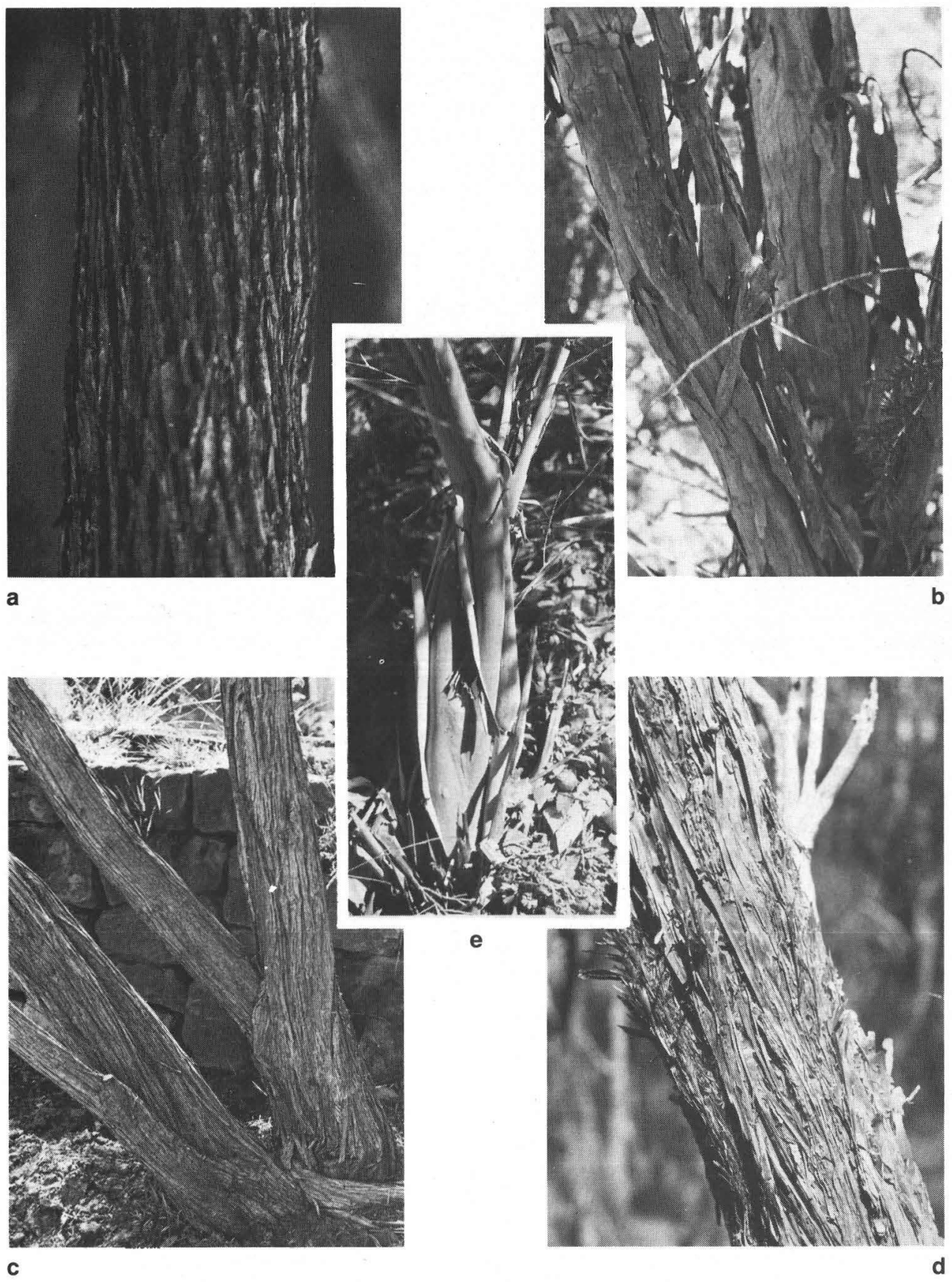

Fig. 1. Bark types. a. Close, fibrous bark, L. lanigerum (Tidbinbilla Nature Reserve, ACT). b. Smooth and exfoliating bark, persisting on the stems, L. grandifolium (Kosciusko National Park, NSW). c. Flaky and fibrous bark, L. petersonii (Mosman, NSW, cult.). d. Bark in many papery layers, L. trinervium (Mittagong, NSW). e. Smooth bark, seasonally exfoliating and shed, L. luehmannii (Mosman, NSW, cult.). 


\section{Leaves}

All species observed produce several pairs of opposite leaves before development of the spiral condition. All mature Leptospermum plants have spiral leaves and bracts, only the bracteoles being subopposite or opposite.

Mature leaves are usually narrow and are rarely more than a few centimetres long (in most species no more than one $\mathrm{cm}$ in length). Leaf-size is consistent within a narrow range in some species and covers a wide range in others. However, in a number of species, individuals with a leaf-size beyond the normal range are not uncommon. Variation of leaf-shape in L. scoparium, including change of shape after transplanting to a different locality, is discussed by Burrell (1965). Some species have a distinct short petiole, as in $L$. parvifolium, and some lack one, but in most the petiole varies according to the position of its leaf on the plant. In spite of the difficulty in quantifying them, there are useful diagnostic characters carried by this region. Often the base of the midrib is very stout as seen on the lower leaf-surface. Many species are variable in the nature of the leaf-apex but the apex does provide some useful diagnostic characters. It is often unthickened, somewhat grooved on the upper surface and with a tendency to recurve. It may bear a short blunt point which, owing to the curvature, is behind the tip. Although occasionally retuse, it may, when not so, appear retuse when the tip is strongly recurved as in $L$. wooroonooran. When the tip is thickened it may vary within the species in the degree of pungency, but in species such as $L$. squarrosum the area below the point is stiff and triquetrous and the point long and pungent. Leaf-texture is generally scleromorphic but, in detail, is usually characteristic for the species. Leaf-margins are always entire but may vary from rounded and smooth to minutely tuberculate, a character that has been used diagnostically (Willis 1973). The minute tubercles are seen best in dried leaves, where, in many species, their presence can vary with the turgor of the individual leaf. The leaf-venation is derivative from brochidodromy, varying within as well as between species, and is often difficult to observe. Usually three, but sometimes more, main veins, separated by reticulation, are conspicuous near the base of the lower leaf surface. The curvature of the outer vein to form an intramarginal vein seems to be associated with leaf-shape. Extra veins are often present in juvenile plants. The leaves of most species are pubescent at least in part and when young, and this pubescence tends to persist longer on the lower surface, the margins and the base. Though useful in general, pubescence is far from reliable in defining species. The cuticle was studied by Johnson (1980) who observed cuticular papillae in the related $L$. laevigatum, $L$. coriaceum and $L$. glaucescens. Johnson also studied the stomates but this study did not associate species considered related morphologically or to distinguish between Leptospermum and related genera. Leaf chemistry has been studied, but, with the exception of the work of Flynn et al. (1979), has not been associated with accurately named specimens. However, it has been possible to locate material in the herbarium that would have been part of that used by Penfold (1922) and to reinterpret his results. This has shown that he considered the essential oils of three subspecies of L. polygalifolium to differ. Two species, $L$. liversidgei and $L$. petersonii, are lemon-scented, the latter not invariably. There is another aromatic scent, very strong in $L$. morrisonii but associated with a number of other species, that has now been chemically identified as the $\beta$-triketone grandiflorone (J. Brophy, pers. comm., see Hellyer \& Pinhey, 1966).

The disposition of the leaves in relation to the stem is often characteristic for a species and helpful for identification. Although somewhat variable in each species the angle of divergence affects the appearance of the plant, as does the 


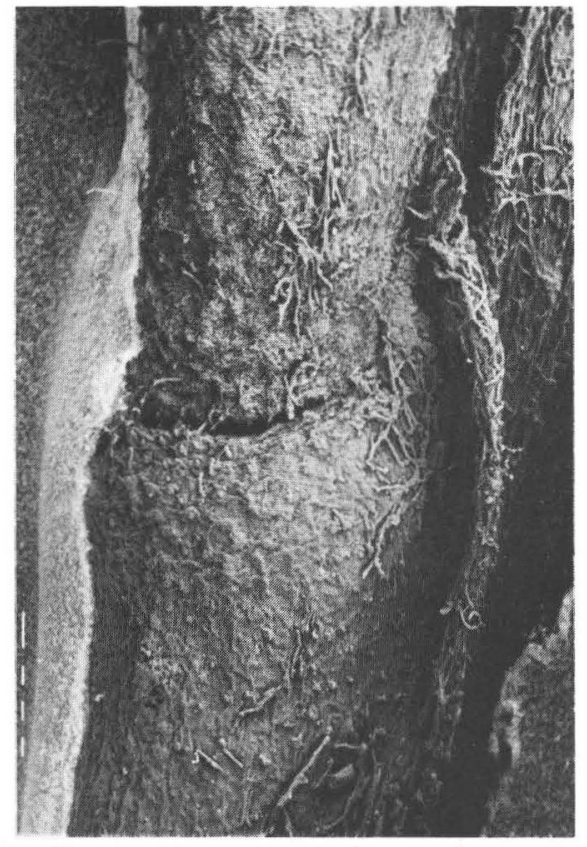

a

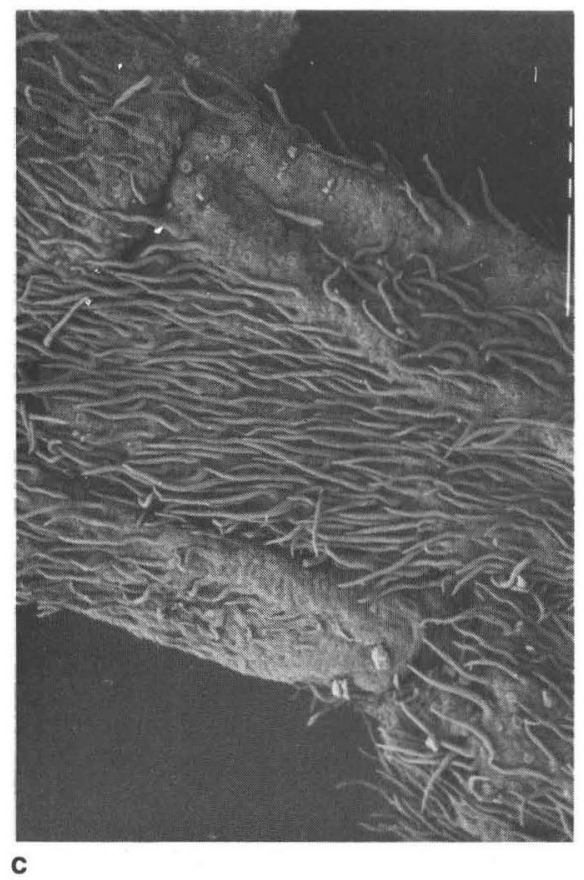

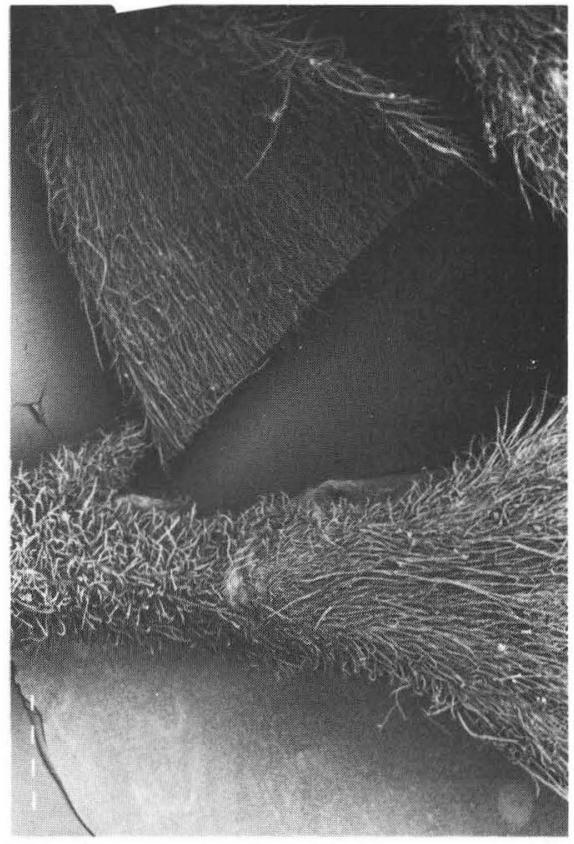

b

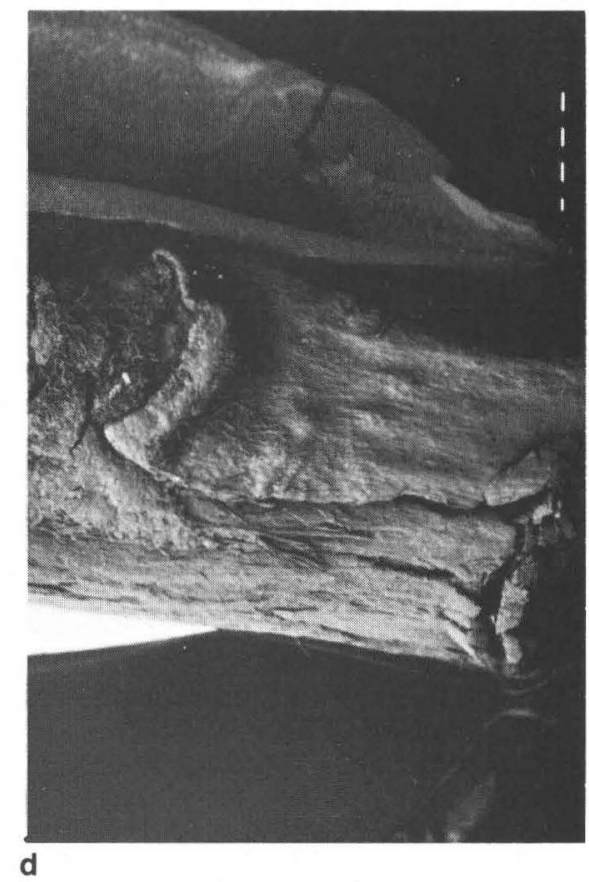

Fig. 2. Leaf-stem junction. a. L. javanicum. b. L. grandifolium. c. L. laevigatum. d. $L$. inelegans. Scale (longest or shortest marker bar) $=200 \mu \mathrm{m}$. 
degree of curvature of the leaf itself. Leptospermum is characterised by a rather sharp transition from leaves to bracts in the flowering region (Thompson 1983) that distinguishes it from Pericalymma, but some species show modification of leaves in this region. In many species all leaves on the upper (flowering) part of the plant are smaller than the earlier leaves of a more vegetative phase, while in a few, such as $L$. lanigerum, some of the leaves close to the flower may have reduced blades and wider petioles. The pattern of oil-glands as seen in the dried leaves is often similar in apparently related species.

\section{Inflorescence}

The inflorescence of Leptospermum was generally misunderstood until Briggs and Johnson (1979) showed that the flowering shoot consists of a growth unit (fig. 3a) terminated by a vegetative bud and bearing one to several axillary bracteolate monads (with occasional triads in $L$. purpurascens) in bract-axils. The presence of several flowers on the flowering shoot had been observed by various authors and used not only to associate several species of the $L$. brachyandrum subgroup of Group 1 but to show (erroneously) that these were species of Agonis. Several flowers also develop on the shoot of other species, including $L$. emarginatum of Group 2, but most workers have failed to observe the extra flowers and have assumed the flowering shoot (the "inflorescence"), even of the numerous two-flowered species, to be one-flowered.

In L. glaucescens (fig. 3c) the usual condition is for the flowers to be monads in the axils of normal leaves, though occasionally this species can be found with $L$. laevigatum-type flowering shoots. Flowering as monads in leaf-axils can also be seen in regrowth ("reversion shoots") of L. trinervium. Most species have extra bracts below those subtending flowers (fig. 3 b) but a few, e.g. L. oligandrum, lack these. The number of bracts on the flowering shoots varies according to the species. It is associated with the patterns of development of seasonal growth units so that shortly branched species usually have fewer bracts. When the bracts remain small it is easy to note the constant presence of the terminal vegetative bud, but in most species the bracts are somewhat to much enlarged and enclose the bud (fig. 3d); and often the flower (or the larger when two flowers develop) appears terminal. This bud and its development are most important as they control the form of the plants, as does the timing of this development. If precocious the bud can leave flowers as monads at the base of a leafy shoot (fig. 3e), if of very restricted development it can result in a plant with very short flowering side-branches along older stems, and if aborted it can result in apparent cauliflory; but as the terminal bud and the flowering shoot developing from it have the plasticity of vegetative parts they are unreliable for use in classification.

The paired bracteoles (prophylls) subtend the hypanthium and are usually similar in texture to the bracts, this texture often being scarious but in some species firmer. Many species have bracts and bracteoles so readily deciduous as to be rarely observed, while others hold them about the opened flower. Bracteoles are often difficult to distinguish in the mass of imbricate tissues, especially where two flowers are involved, but are sometimes, as in $L$. polygalifolium (fig. $3 \mathrm{~g}$ ), large enough to overlap and envelop the mature bud, while in $L$. trinervium (fig. $3 \mathrm{f}$ ) they remain lateral though large and it is the inner bracts that become broad and protective. In some species, such as $L$. lanigerum, the long sepals soon protrude through the rather rigid imbricate bracts surrounding the bud. 

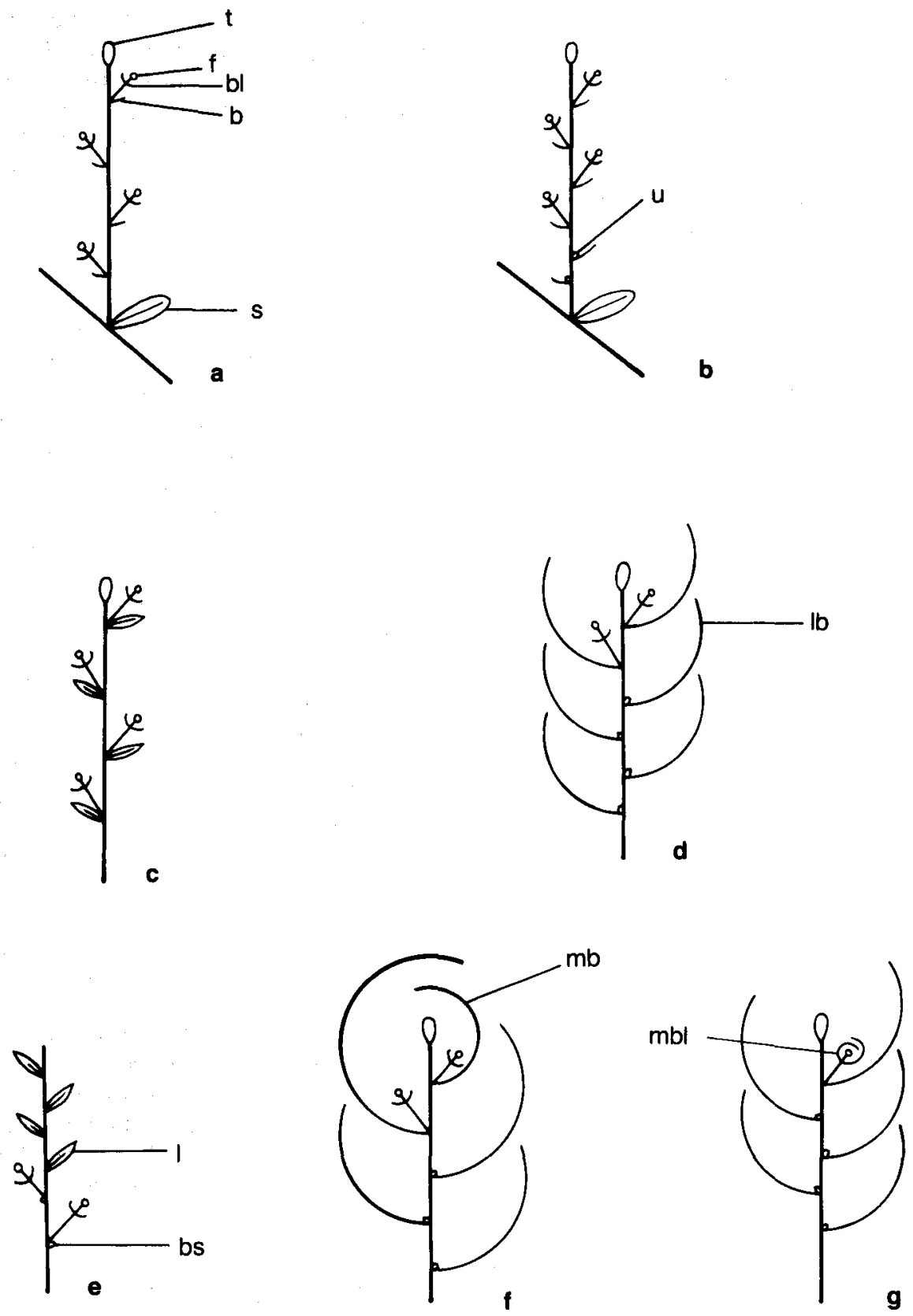

Fig. 3. Flowering roots - showing different forms found in Leptospermum (diagrammatic). (See text for discussion.) $b=$ bract; $b l=$ bracteole; $b s=$ bract scar; $f=$ flower; $l=$ leaf of former terminal bud; $\mathrm{lb}=$ large bract; $\mathrm{mb}=$ much enlarged bract; $\mathrm{mbl}=$ much enlarged bracteole; $\mathrm{s}=$ subtending leaf; $\mathrm{t}=$ terminal vegetative bud; $\mathrm{u}=$ undeveloped floral bud. 
The flowering shoot is sometimes axillary, and this can be seen clearly in $L$. brachyandrum and L. oligandrum, but for the vast majority of species a second unit of modified vegetative growth intervenes and there are two stages to flower-development. The apparently axillary flowering shoots of some species, when carefully examined, are seen to be at the end of a short stem topped by scars. This feature is hard to see in the truncated side-branches of some of the Western Australian species, but is readily seen in the more expansive leafiness of some of the eastern species. Whether at the ends of slender leafy growth or on a succession of short branches extending from adjacent stout stems below the leafy branches, these flowering shoots are usually massed.

\section{Flowering time}

Estimations of flowering time given here are based on herbarium material and are not necessarily exact. Most species flower very prolifically over a few weeks in spring and early summer and sporadically (in a few individuals) at other times. L. squarrosum has a major flowering in autumn. Western Australian species are spring-flowering as is to be expected in the Mediterranean climate of the southwest of the continent. Owing to the tendency for out-of-season flowers to be over-represented in collections, there is little record in the herbarium of the time of maximum flowering and of the difference in the peak with change of altitude and latitude. In the field the time of maximum flowering differs in the sympatric $L$. speciosum and $L$. whitei but other sympatric species such as $L$. myrtifolium and L. continentale flower together.

\section{Flowers}

The individual flower of Leptospermum is relatively simple and rather uniform (fig. 5c). The hypanthium often grades into a pedicel bearing two evanescent bracteoles that sometimes leave prominent scars. The ovary is enclosed by the hypanthium which is fused to its wall. The top of the hypanthium extends beyond the top of the ovary and bears persistent or deciduous sepals, petals that are readily deciduous and stamens that are usually readily deciduous. The loculi usually extend above the base of the style. The floral parts, the sepals, petals and staminal groups, are in fives and are attached to the hypanthium rim. The outer parts are imbricate, forming a cover to the bud while the stamens lying below them are incurved towards the short stigma. Flower size varies between species, from a few millimetres diameter to two or more centimetres, but there can also be some variation within species, especially a tendency to form abnormally small flowers under conditions of stress. Flowers are usually very conspicuous, being produced in large numbers on many plants at the peak of the flowering season, but they are inconspicuous and usually few on the scattered individual plants often seen flowering out of season.

In many, perhaps all, species a number of flowers lacking female parts are to be seen. From herbarium material this is difficult to detect and the proportion of these flowers in the individual species impossible to assess.

\section{Hypanthium}

The hypanthium exhibits valuable diagnostic features. It may be sessile, as in L. squarrosum (fig. $4 \mathrm{c}$ ) and $L$. macgillivrayi (fig. $4 \mathrm{~g}$ ), or pedicellate as in $L$. brevipes (fig. 4a, b) and L. maxwellii (fig. 4d). The term "pedicel" is used here for the structure below the ovary, i.e. the anthopodium of Briggs \& Johnson 
(1979). The length of the pedicel in relation to that of the hypanthium is usually rather constant within a species but occasionally shows much infraspecific variation. L. brevipes (fig. $4 \mathrm{a}, \mathrm{b}$ ) and $L$. trinervium each have both a short) and a long-pedicellate form. These are usually separated geographically but are often observed to be sympatric. L. fastigiatum (fig. 4f) is pedicellate only in fruit. Also of significance is the area of transition from pedicel to hypanthium which is sometimes well-defined but often obscure. The shape of the base of the hypanthium, though variable, is often diagnostic, as in $L$. brevipes (fig. 4a) and L. squarrosum (fig. 4c) where it is broad and rounded and L. maxwellii (fig. 4d), L. scoparium (fig. 4e) and L. macgillivrayi (fig. 4g) where it tapers, in the case of $L$. maxwellii to a tapered pedicel. The shape is often associated with the shape of the enclosed loculi. The size of the hypanthium is most readily measured as a diameter and is not always in proportion to other floral parts.

The texture of the hypanthium may vary in turgor, being especially turgid in those few species, such as L. glaucescens, where, in the fruit, it may become coloured and succulent.

The upper (free) part of the hypanthium above the level of the ovary-top, though always proportionate in length to the lower part helps to distinguish some species. In some, e.g. $L$. spinescens, $L$. macgillivrayi (fig. $4 \mathrm{~g}$ ) and $L$. subglabratum, it is incurved to lie over the outer part of the ovary-top, in others, as in L. erubescens and L. brevipes (fig. 4a,b), it is a little widened and erect so as to appear as a rim, while in species such as $L$. incanum and $L$. maxwellii (fig. 4d), it is expanded and erect so that the hypanthium is infundibuliform. The pubescence of the hypanthium often characterises species but as it can vary in, or be lost from, individual plants it cannot be relied on as diagnostic in every case. Most of the many species with a densely pubescent hypanthium and pedicel have fewer hairs on the upper (free) part. Many of those numerous species that have an almost glabrous hypanthium may bear hairs on the pedicel. L. myrsinoides has been distinguished in the past by a hypanthium silky in the lower part and glabrous above, but L. myrsinoides is neither consistent in this feature nor the only species to show it. Species such as L. laevigatum that usually have a glabrous hypanthium are occasionally pubescent, and the usually pubescent $L$. trinervium can have a glabrous hypanthium.

\section{Sepals}

The five sepals are always imbricate but the amount of overlap varies. The almost cymbiform tips of the sepals in some species are associated with their packing in the bud. All species of Group 1 have persistent sepals, mostly ovatedeltoid, pubescent, at least in part, or glabrous, and becoming scarious toward the margins. L. macgillivrayi is unique in having wafer-thin obtuse sepals, while $L$. confertum has turgid sepals with pale scarious margins. In Group 2, while many species, such as $L$. lanigerum, have persistent sepals (some such as in $L$. nitidum long-deltoid and conspicuous), most have sepals that develop a basal abscission layer that allows them to be shed as the fruit develops. The formation of this layer is rather erratic in a few species, as in L. liversidgei, but the layer is usually well developed, often with the sepal pale and thin above it. The sepals are not conspicuously coloured but may, according to the species, be green, light brown or even pinkish red. In L. macgillivrayi they are creamcoloured. 

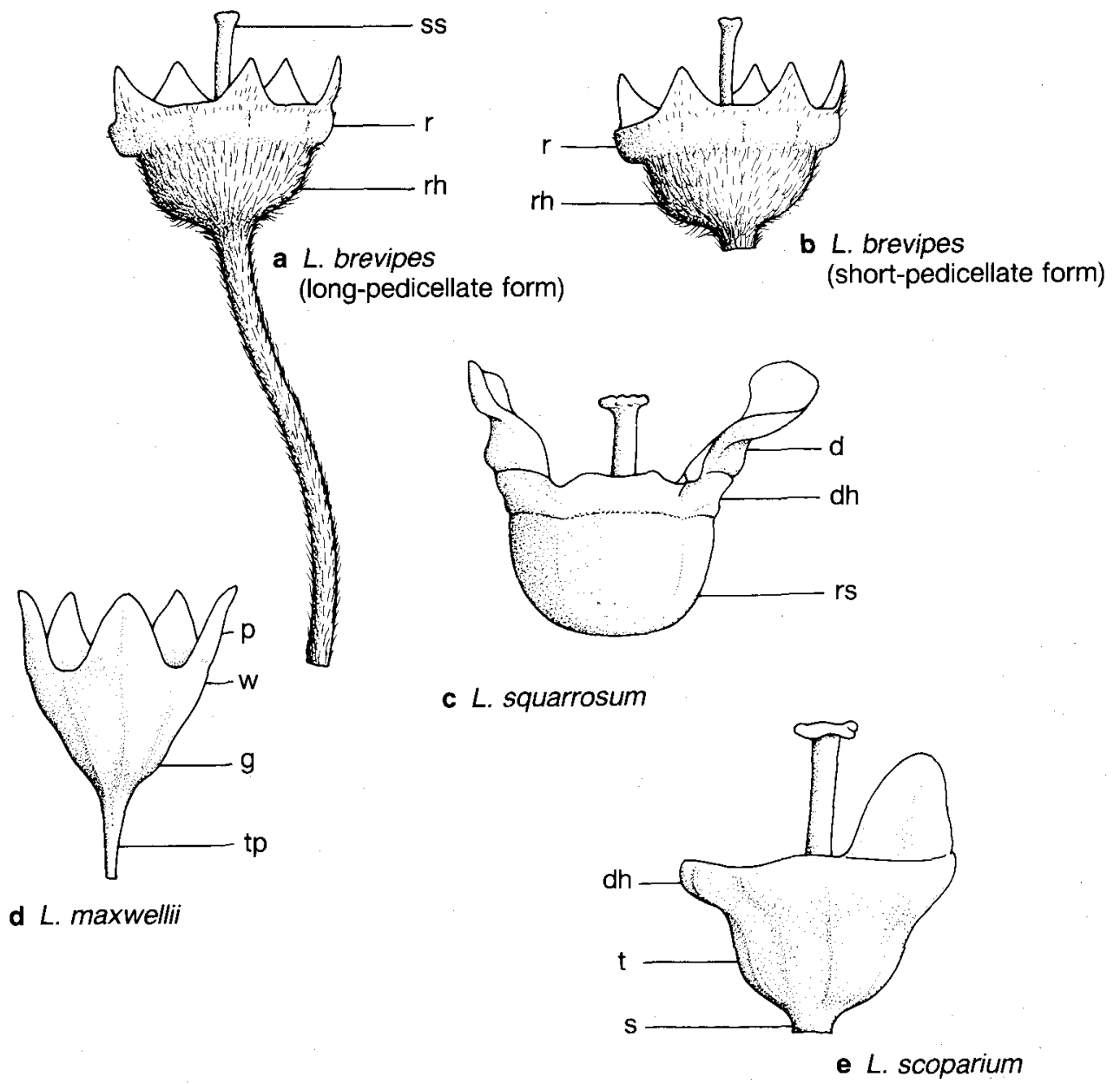

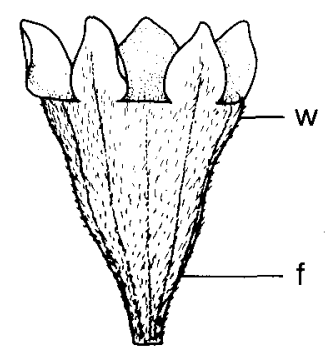

f L. fastigiatum

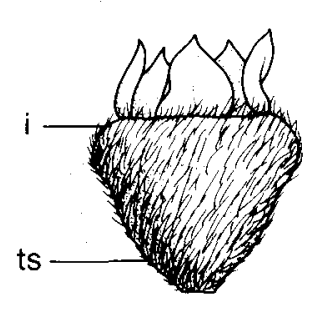

g L. macgillivrayi

Fig. 4. Lateral view of young fruits. (See text for discussion.) a = dehiscent sepal; $\mathrm{dh}=$ somewhat widened and differentiated upper part of hypanthium; $f=$ tapered fluted hypanthium developing a pedicel; $\mathrm{g}=$ gradually tapered hypanthium; $\mathrm{i}=$ incurved upper part of hypanthium; $\mathbf{p}=$ persistent sepal; $r=$ upper part of hypanthium forming a rim; $\mathrm{rh}=$ rounded hypanthium-base with sudden taper to a scarcely tapered pedicel; $\mathbf{r s}=$ rounded sessile hypanthium; $s=$ tapered hypanthium with short broad pedicel; ss = stigma and style; $t=$ tapered hypanthium; $t \mathrm{p}=$ tapered pedicel; $\mathrm{ts}=$ tapered sessile hypanthium; $w=$ widened upper part of hypanthium. 


\section{Petals}

The five petals are obovate, often with an attenuation of the base that appears to vary within the flower as well as the species, and which is impractical to assess from herbarium specimens. Length was measured from herbarium specimens in order to relate all species but this reduces considerably the measurements that would be found in fresh specimens. In all species except $L$. minutifolium (which has small petals disproportionate to other floral parts) petals are longer, often much longer, than the stamens. The majority of species have white petals but in some these may be flushed with pink at the base. Some species may have some pink-flowered individuals while in others the petals are always pink. $L$. macrocarpum may have white, pink or red flowers, the last as a regional variant, and $L$. spectabile is uniformly dark red. Pink and red variants of $L$. scoparium occur in New Zealand but in Australia the petals are always white.

\section{Stamens}

Leptospermum stamens are arranged in groups (staminal bundles), each of which is centred opposite a petal (fig. 5c, Johnson \& Briggs (1984), fig. 8). In dried specimens this arrangement is not obvious but in fresh flowers the curvature of the filaments shows their grouping within the continuous ring of stamens on the hypanthium edge. In some species the stamens are of almost equal length while in others the length within the bundle varies; always, however, the central stamen is shorter than the two on each side of it (the longest of the group) (fig. 5b) and the outer stamens of the group (if present) are shorter, later to unfold and variable in number within the flower as well as within and between species. As a result of this variability the number of stamens per bundle must usually be expressed as a range. In the bud the longer stamens are incurved or extend almost horizontally from the hypanthium to the stigma that is at approximately the same level (fig. 5a). The anthers face downward and the gland behind them lies near the stigma. The longer stamens lift first, before their anthers dehisce. That plants are self-compatible has been shown for $L$. scoparium in New Zealand (Burrell 1965).

The anthers of Group 1 species have two shallow and closely parallel cells, each with a layer of tissue at the base (fig. 6a). After dehiscence this layer is exposed as the pollen is shed. Two eastern Australian species, $L$. trinervium and $L$. subglabratum are exceptional in this group in having deep anthers, i.e. anthers where the dehiscent surface is well above the base. Deep anthers are universal in Group 2 species, but in other anther features this group is much less uniform than Group 1. The size of the anther-opening is restricted in some species and in these species the cells are often seen as diverging or separated (fig. 6c). This feature has never been remarked in literature but was illustrated (rather crudely) by J.C. Wendland \& Schrader (1797) in their publication of Melaleuca thea (L. polygalifolium). This condition is constant in L. polygalifolium (fig. 6c) and $L$. morrisonii. In $L$. lanigerum and a number of other species of Group 2 there is considerable development of the tissue at the base of the cell. This is very obvious in the huge anthers of $L$. macrocarpum (fig. 6d). Some species show a tendency for the cells to either fold back (towards the filament, fig. 6a) or to curve in the other dimension, i.e. across the top of the filament (fig. 6d). The size of the anther-cell is usually \pm constant for the species but varies between species.

The filament is extremely narrow at the apex where it attaches to the back of the anther beside a conspicuous gland (fig. 6b). In some western species this 


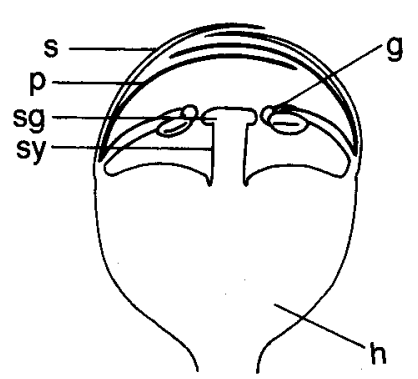

a

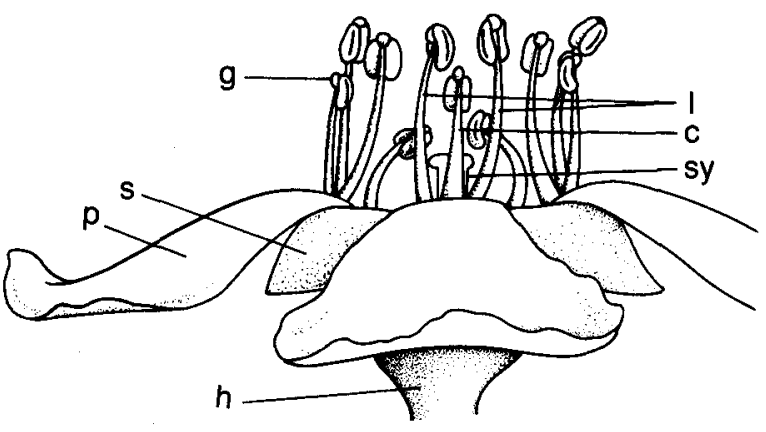

b

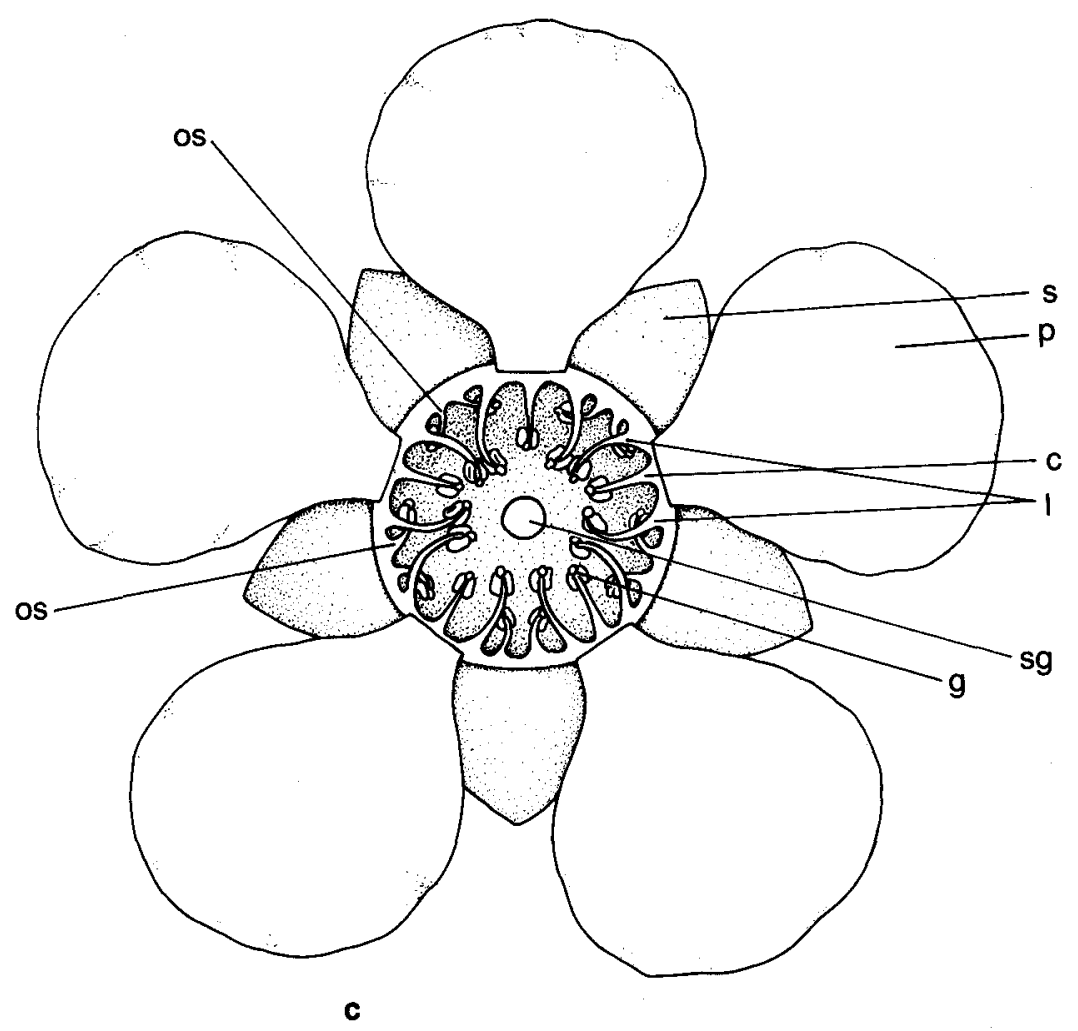

Fig. 5. Disposition of stamens in buds and flowers. a. Cross-section of bud. b. Side view of flower. c. Plan view of flower. (See text for discussion.) $c=$ central stamen of the bundle; $g=$ gland; $h=$ hypanthium; $1=$ longest stamen of the bundle; $p=$ petal; $s=$ sepal; sg = stigma; sy $=$ style. 
narrowing is abrupt but in most species the filament tapers gradually to its apex. A number of species show filaments dilated laterally at the base (splayed) and in some, such as L. sejunctum, the lower parts of stamens in the same group tend to fuse. Most species of Group 1 have short filaments less than 2 $\mathrm{mm}$ long, whereas in most species of Group 2 they are $3 \mathrm{~mm}$ or more. Hairs are found on the filaments, consistently in $L$. deanei (fig. 6b), inconsistently in $L$. polyanthum and very rarely in other species.

\section{Top of the ovary}

The surface of the ovary-top varies from glabrous to densely pubescent. All species of Group 2 have the surface glabrous and often shining with nectar. Most species of Group 1 have the surface variously and often densely pubescent, sometimes with short, erect hairs, and sometimes silky, but the species $L$. brachyandrum, L. spinescens, $L$. macgillivrayi and $L$. exsertum are exceptional in being consistently glabrous. The shape of this area may vary (fig. 7) from flat to slightly or conspicuously domed, and in $L$. exsertum it is almost conical. Some species, such as $L$. luehmannii, have the surface raised above each loculus of the ovary below. The shape of the domed surface is accentuated with the maturing of the flower and fruit and is best observed in association with fruit characters. In the flower the ovary-top is at first rather flat, with the style-base (in most species) inset, but often the surface later becomes raised either over the whole top or that part of it surrounding the style.

\section{Stigma and style}

The style is simple, as in all Myrtaceae, usually with its base inset in the top of the ovary (fig. 7a), the proportion inset being associated with the position of the placenta in the ovary. In a few species the surface of the ovary does not descend around the base of the style but is horizontal or raised to extend upward over a style-base (fig. 7b) which often adheres irregularly to the dehiscing fruit-valves. The style may be stout or slender and is often stout-based and tapering (fig. 7d). Though constant within species this feature is rarely diagnostic for a group. An exception is the style in $L$. scoparium, $L$. juniperinum, $L$. continentale, $L$. rupicola and L. squarrosum (fig. 8c), which is characteristically straight-sided with a disproportionately large flat stigma, but the style of the apparently unrelated species, L. liversidgei, is somewhat similar. Many species regularly or occasionally produce flowers in which the style is reduced or aborted (fig. 7c). In these flowers the style may be either unnaturally short, absent so that the stigma is sessile on the ovary-top, or absent with the stigma also absent so that the ovules abort. In a number of those species with a pubescence on the ovary-top, a few hairs can be found on the style-base. The size of the stigma, i.e. large or small, is best expressed in relation to the length of the style and is constant in many species (fig. 7). The stigma is sometimes noticeably lobed, the number of lobes corresponding to the number of ovary-loculi (fig. 7a), but this feature is rarely uniform within a species and its retention on herbarium specimens may depend on the drying process. Observation of living flowers may show it to be of some diagnostic value, as may be features of the stigmatic surface not studied here. Primack \& Lloyd (1980) found the stigma of $L$. scoparium to be receptive throughout the life of the flower. 

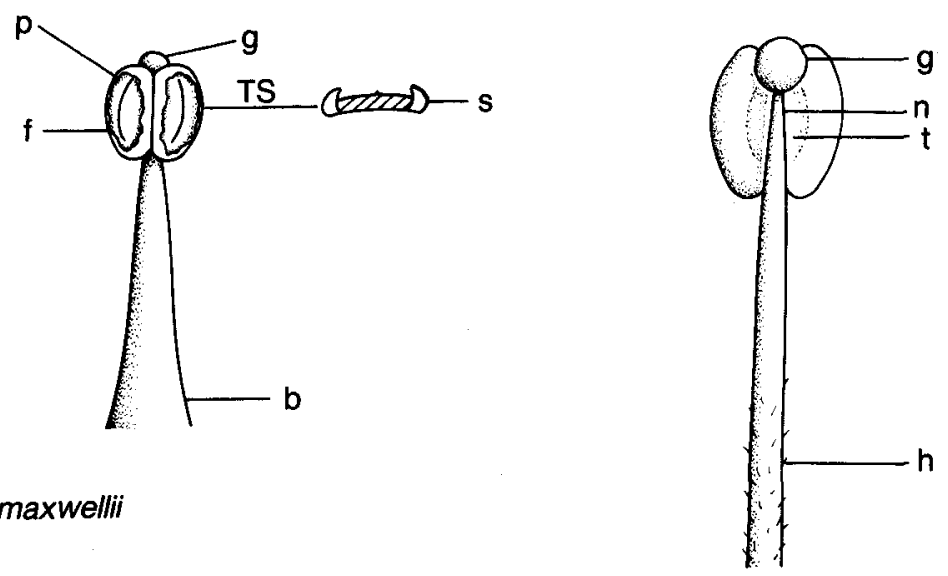

a L. maxwellii

b L. deanei

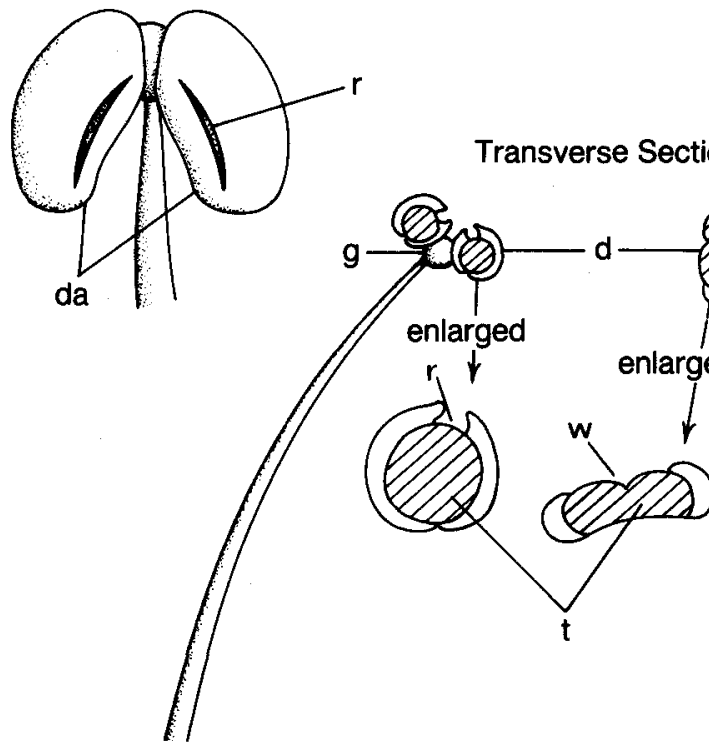

c L. polygalifolium

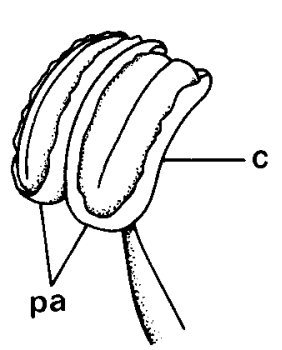

Fig. 6. Stamens after dehiscence. (See text for discussion.) $b=$ broad (splayed) filament base; $c=$ curved anther cell; $d=$ deep anther cells; $d a=$ divergent anther cells; $f=$ cell folded back; $g=$ gland; $h=$ hairs on filament; $n=$ narrowed apex of filament; $p=$ primitive (group 1 type) shallow anther cell opening wide; $p a=$ parallel anther cells; $r=$ restricted opening; $\mathrm{s}=$ shallow cell; $\mathrm{t}=$ thickened area; $\mathrm{w}=$ wide opening. 


\section{Ovary}

The ovary has (2-)3-10 or more loculi, each with a placenta on the adaxial wall and numerous ovules. The number of loculi has long been used as a diagnostic character. However, this feature, while valuable in defining some species, is variable in many more species than has been supposed. This lack of careful observation has rendered misleading most published keys to species. A number of species regularly have 3 loculi, others 5 loculi, but many show variation with fruit of 3, 4 and 5 loculi on the same branch. L. laevigatum usually has more than 5 loculi (up to 10 or even more), and several other species show occasional fruit with more than 5 loculi. The placenta is peltate and usually attached somewhat above the middle of the axis (fig. 8a-d). In some species the placenta is attached so high in the loculus that all ovules are descending (pendulous) with the uppermost aborted. This is seen in $L$. maxwellii (fig. $8 \mathrm{~b}$ ). $L$. parvifolium is the only species of Leptospermum having the placenta attached low and most of its ovules ascending (fig. 8d). In most species the placenta has, on the distal surface, about 60 ovules spreading or descending according to their position, and distributed in unequal numbers in about six rows (fig. 8a, e). The distal surface of the placenta is narrow and the ovules in only two rows in several species, e.g. L. glaucescens and L. laevigatum (fig. 8f). It is broad with ten or more rows in others, such as $L$. morrisonii. In some species the upper part extends so far into the loculus that all or most ovules are descending. This is especially conspicuous in the high placentas of $L$. petersonii and L. javanicum (fig. 8c), and has been illustrated by Tison (1876), but obviously from an exceptionally modified individual of $L$. javanicum. Tison also illustrated the narrow, as in $L$. coriaceum, broad, as in L. lanigerum, and average-sized, as in L. myrsinoides (fig. 8a), placentas found in the genus. Viewed laterally the placenta may be seen to be shallow or deep (extending into the loculus), and its distal surface to be flat or rounded. Placentas that do not extend far from the axis or that are short (small) allow space for more ovule-development in the loculus.

Some characteristics of the placenta can often be observed in opened fruit, see fig. $9 b$.

\section{Ovules}

The ovules are anatropous and are arranged in vertical rows on the placenta (fig. $8 \mathrm{e}, \mathrm{f}$ ). The structure of those of $L$. laevigatum is well illustrated and described by Johnson (1984), and, apart from the wing on its seed, this species is likely to represent the genus well. Usually a number of ovules fail to develop to maturity; occasionally these are vestigial but most develop at least part of the way towards maturity. The position of these unsuccessful ovules is not fixed though they tend to occupy the more cramped part of the loculus. The proportion developing varies between species but also varies considerably within species probably depending on environmental conditions.

\section{Fruit}

The fruit is a loculicidal capsule, in general of a depressed-globular shape (fig. 9a) but occasionally hemispherical or spherical. It opens by the splitting of the top of each loculus (fig. 9b). The fruit of Group 1 species show little tendency to remain on the plant after they have matured, with the exception of those of the highly modified $L$. spinescens and $L$. confertum. The myth that all species of Leptospermum have woody fruit that remain in position on the plant until the 


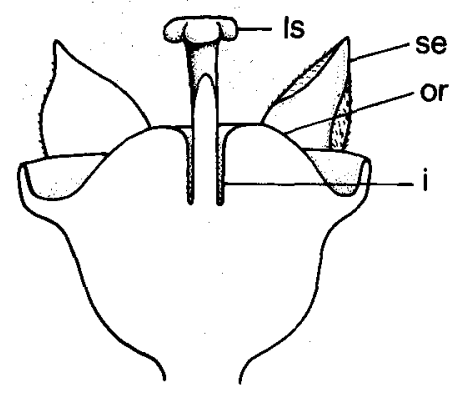

a L. Iuehmannii
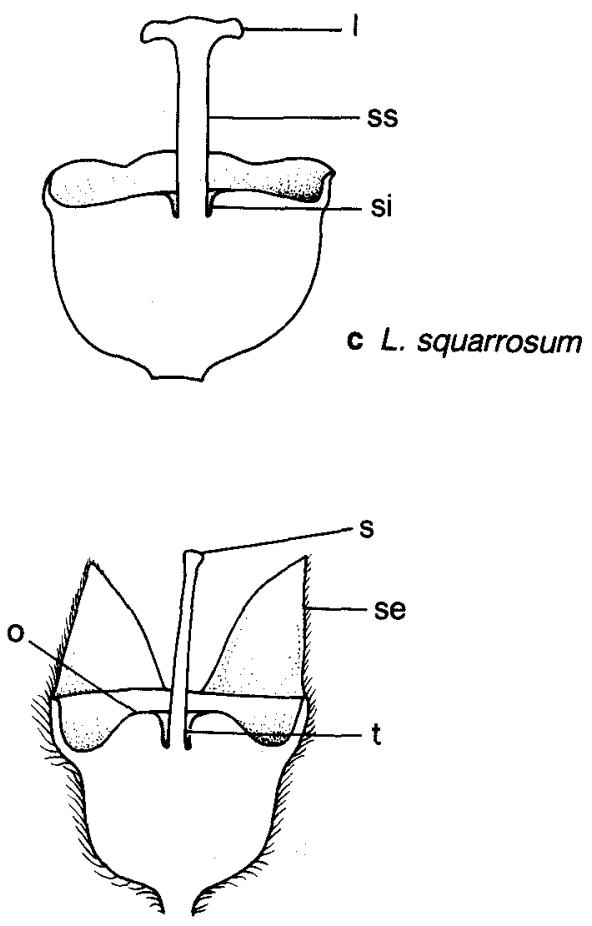

d L. trinervium

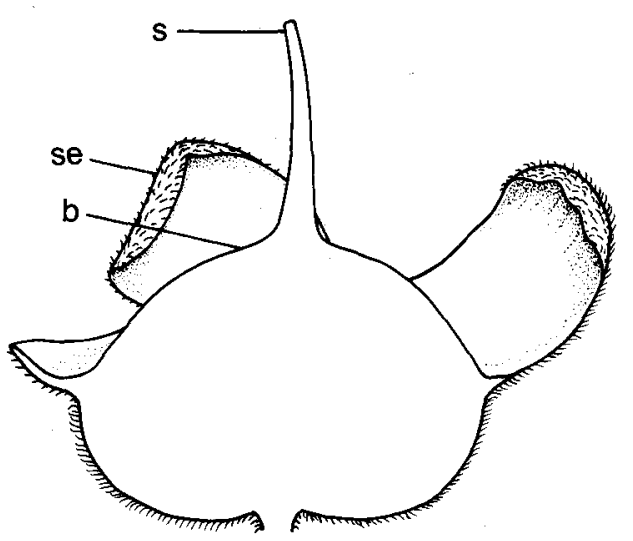

b L. macrocarpum
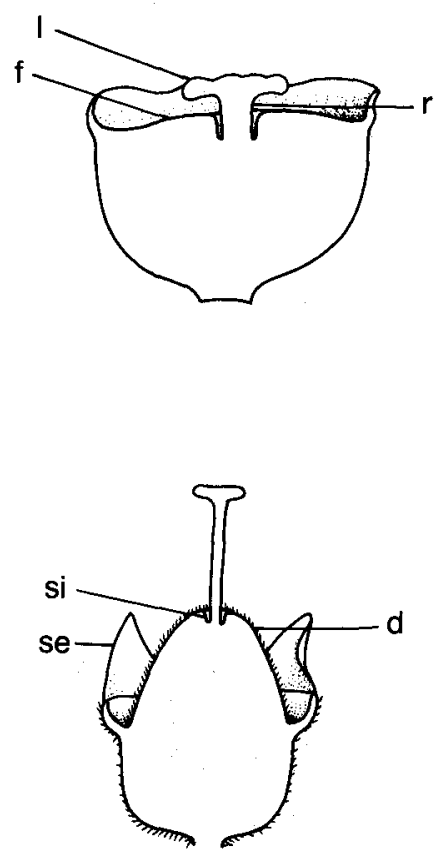

e L. multicaule

Fig. 7. Style and ovary-top. (As seen in young fruit. Not to scale. See text for discussion.) $b=$ surface of ovary raised at the base of the style which is not inset; $d$ = surface of ovary forming a high dome; $f=$ surface of ovary almost flat; $i=$ style base well inset; $1=$ large stigma; ls = lobed stigma; $o=$ surface of ovary raised near the style; or $=$ surface of ovary raised above each loculus; $r=$ reduced style; $s=$ small stigma; se = sepal; $s i=$ style shallowly inset; $s s=$ almost straight-sided style; $t=$ tapering and stout-based style. 


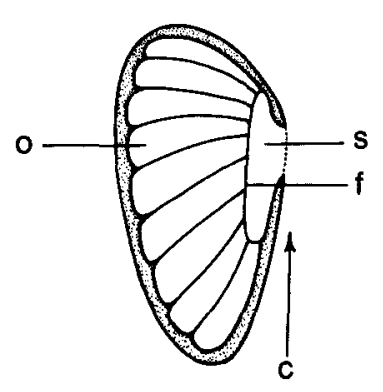

a L. myrsinoides

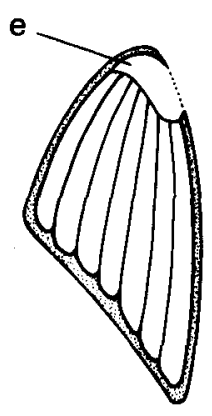

c L. javanicum

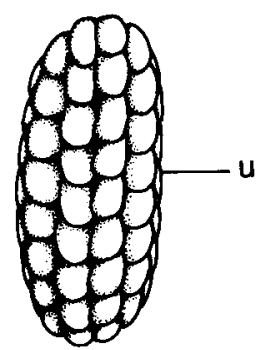

e L. myrsinoides

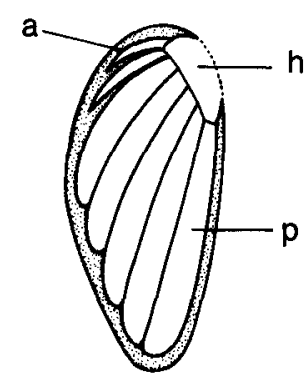

b L. maxwellii

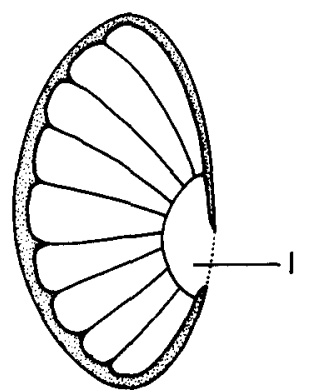

d L. parvifolium

\section{f L. laevigatum}

Fig. 8. Disposition of ovules in ovary (diagrammatic), shown in lateral view (a-d) and distal view (e, f). (See text for discussion.) $a=$ aborted ovules; $c=$ central axis of the loculus; $e=$ placenta extended in upper part; $f=$ flat distal surface of placenta; $h=$ short placenta attached high in the loculus; 1 = placenta low in the loculus; $n$ = narrow placenta showing ovules in 2 rows; $o=$ ovules in rows on distal surface; $p=$ pendulous ovules; $s$ = shallow peltate placenta; $u=$ placenta of usual proportions showing $c .30$ ovules in 4-6 rows. 
seed is released by fire is thoroughly entrenched in ecological literature (Burrell 1981; Specht 1981). In fact the species most often mentioned in the context of fire in heathland, L. myrsinoides, is a typical fruit-shedding member of Group 1.

The texture of the part of the fruit surrounded by the hypanthium changes with maturity, changing greatly in species that retain their fruit for a number of seasons. Unfortunately for the usefulness of this character in herbarium material, it may vary within a species according to conditions affecting the individual plant or population, so that fruit on a plant that has matured early and shed its seed from young fruit has quite a different aspect from fruit of the same species held in situ and becoming scaly or gnarled over several years. In some species, such as $L$. myrtifolium and L. lanigerum, a thin surface layer can often be seen to lift almost as a piece from the fruit, while in others the surface remains, smooth or cracking or, in the case of a turgid or succulent surface, wrinkling. In most species the pedicel, when present at flowering, is retained at the fruiting stage as a stalk, but in species whose fruit continues to enlarge while persisting on the plant this feature can be obscured or even lost, the base of the fruit becoming broad where it is in contact with the stem or in extreme cases submerged in expanding stem tissue. In the normally persistent-fruited Group 2, long-persistence is often associated with the position of the fruit in relation to a stout stem. If the fruit is carried on a very slender branchlet, as in $L$. petersonii, it often fails to persist for many years. In Group 2 only $L$. emarginatum has fruit that is readily shed; this apparently premature fruit-fall may be due to the fragility of the long-attenuate pedicel of this species. The proportion of the height (side view) of the fruit occupied by the valves may vary within the individual species but is still a useful diagnostic character. In some species, especially $L$. nitidum, the valves often may not extend at all above the rim and in others, e.g. L. coriaceum (fig. $9 \mathrm{c}$ ), the valve region is very short. In most species the valve region is deeper so that the valves are shortly to strongly exserted. The shape of this region (side view) is a useful diagnostic feature, the upper surface varying from evenly rounded to having the part around the style disproportionately raised. The opened valves rarely extend much beyond the edge of the hypanthium-top but occasionally, as in forms of L. polygalifolium, they are spread so widely that the fruit base below them is flat. The texture of the valves varies and is difficult to define. In Group 1 species it is stiff but thin, except in L. macgillivrayi where it is translucent and firm, and in L. spinescens where it is extremely woody. In Group 2 it is woody; very thick in $L$. grandiflorum and $L$. liversidgei, delicate in $L$. petersonii (fig. $9 \mathrm{~b}$ ), and scarcely woody in $L$. emarginatum.

There is variation, hard to define, in the tissue surrounding the seeds. This tissue is thin in most species of Group 1. However, in some species of this group, the rigidity of the fruit may be explained by the thickening of this region inside a softer and more turgid exterior. Johnson (1983) illustrates prominent sclerification of cells lining the loculus in L. laevigatum. Perhaps this is the mechanism by which this species, whose fruits are soon shed, survives fire.

Fruit-size varies from a few millimetres in diameter, as in the majority of Group 1 species, to two centimetres in L. macrocarpum. It is not constant in species with persistent fruit, being particularly variable in $L$. micromyrtus.

\section{Seeds}

The seeds in this genus are of simple structure with two seed coats variously adhering to each other. Observation of seed of normal number, shape, size and 
a $L$. petersonii (before opening)

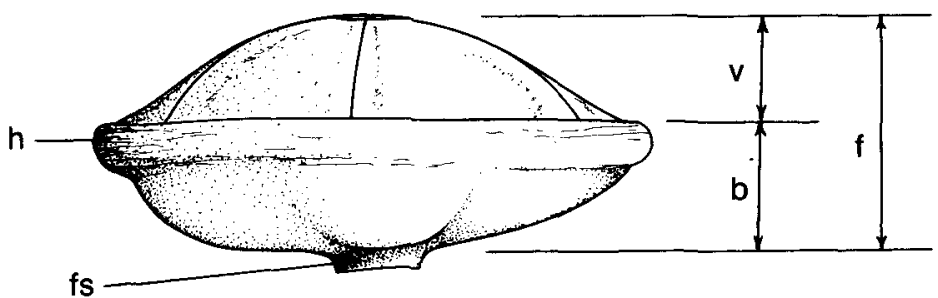

b L. petersonii (after opening)

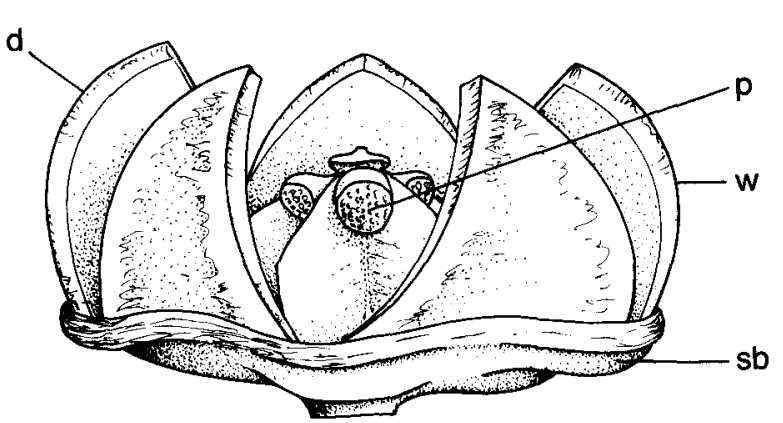

c L. coriaceum (after opening)

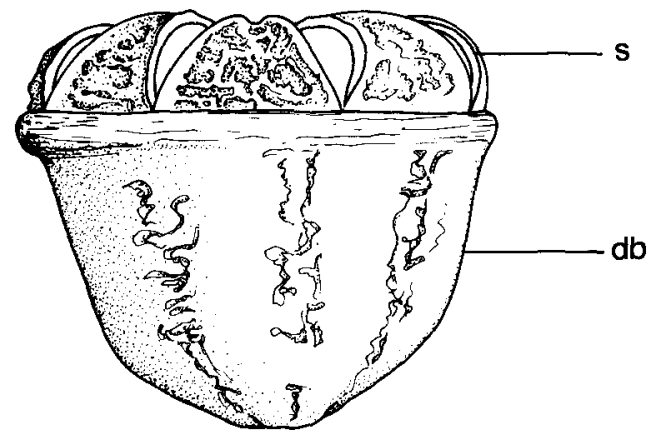

Fig. 9. Capsules, showing variation in valve-base proportions with maturity $(\mathbf{a}, \mathbf{b})$ and between species $(\mathbf{b}, \mathbf{c})$. (See text for discussion.) $b=$ depth of base; $d=$ delicately woody valve; $d b=$ deep base; $f=$ depth of fruit; $f s=$ fruit stalk; $h=$ hypanthium (fruit) rim; $p$ $=$ persistent placenta (with extended top); $\mathrm{s}=$ scarcely exserted valves not opening wide; $\mathrm{sb}=$ shallow base; $\mathrm{v}=$ depth of valve region; $\mathrm{w}=$ well-exserted valves opening wide but not extending beyond the hypanthium-top. 
surface-pattern in this genus is difficult. In herbaria there are few fruiting specimens of those Group 1 species that shed their fruit early. Also outside the short period of maximum flowering most collectors notice and collect only Group 2 species. In specimens of Group 2 species, even with careful collecting it is difficult to assess all seed characters because mature seed is readily shed in the field while immature fruit on herbarium specimens will open on drying and shed immature seed. As the features of the seed vary with maturity, its position in the loculus and the degree of development attained by the fruit from which it is shed, it has not been easy to be sure that any seed observed is both fully developed and normal. The colour of the seed is, in most species, a rather reddish brown, with the shade varying between species and with maturity. Seeds of $L$. divaricatum can be almost black. The seed-coat of all members of Group 1 has a reticulate pattern although this reticulation is not conspicuous in L. brachyandrum (fig. 10a) and its allies. In many species there is a ridge of expanded cells with its position dependent on the packing of the ovules (fig. $10 \mathrm{~b})$. This ridge is extended to forma wing in L. coriaceum and L. laevigatum (fig. 10c). Two western species, L. spinescens (fig. 11a) and L. confertum have the seed surface with a deep reticulation, so narrow as to be apparently striate, that splits into fibres and tends to lift, while in L. multicaule (fig. $11 \mathrm{~b}$ ) and $L$. divaricatum the seeds have a foveate-reticulate surface. The seeds of Group 2 species are all linear-striate (fig. 12,), and in L. liversidgei, L. polygalifolium (fig. $12 \mathrm{a}$ ) and $L$. morrisonii the shallow fibres of the striations break and lift near the centre of the seed.

Seed-shape also differentiates the two groups. The first has a seed usually obovoid to broadly cuneiform or oblong, figs. 10 \& 11, the second has a narrowly cuneiform to irregularly linear and often almost sigmoid seed, fig. 11 . Size is \pm uniform within species and groups of related species. In Group 1, seeds are very small, often c. $1 \mathrm{~mm}$ long, the exceptions being a few of the large-fruited species, i.e. L. spinescens, L. confertum and L. laevigatum, and also the small fruited L. incanum, and L.multicaule and L. divaricatum where only a few ovules (perhaps one) develop at the expense of the other ovules in the loculus. In Group 2, larger seeds are the rule. They are commonly about 2 $\mathrm{mm}$ long but are smaller in $L$. emarginatum and in the small loculi of $L$. liversidgei and L. arachnoides. Very large seeds are found in a number of species (about $5 \mathrm{~mm}$ long in L. macrocarpum), often (but not always) associated with a small placenta.

In all species seeds are produced in great abundance. Samples from a number of species have been germinated to reveal a very low percentage viability, from $\pm 3.5 \%$ in L. glabrescens to $43 \%$ in L. myrsinoides, with an average of $20 \%$ for the species sampled. Burrell (1965) found seed of L. scoparium to be viable when the fruit has developed for about six months and to germinate normally after several years' retention on the plant.

\section{Chromosomes}

The chromosome numbers known for this genus are $2 n=22$ and $2 n=44$. Unfortunately, few counts have been made. The most quoted numbers are those given by Smith-White (1948) but these counts have no vouchers and the names used are unreliable. Rye (1979) has shown that two Western Australian species, $L$. roei and $L$. incanum, have $n=22$. These counts are supported by voucher specimens in Perth. She also found a specimen from Kumarl (unvouchered but probably $L$. incanum or $L$. erubescens) to have $n=11$. 


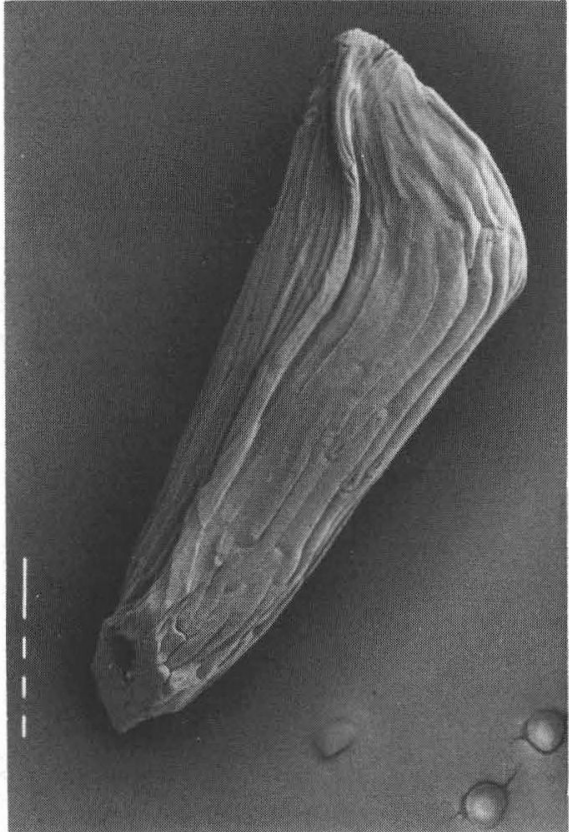

a

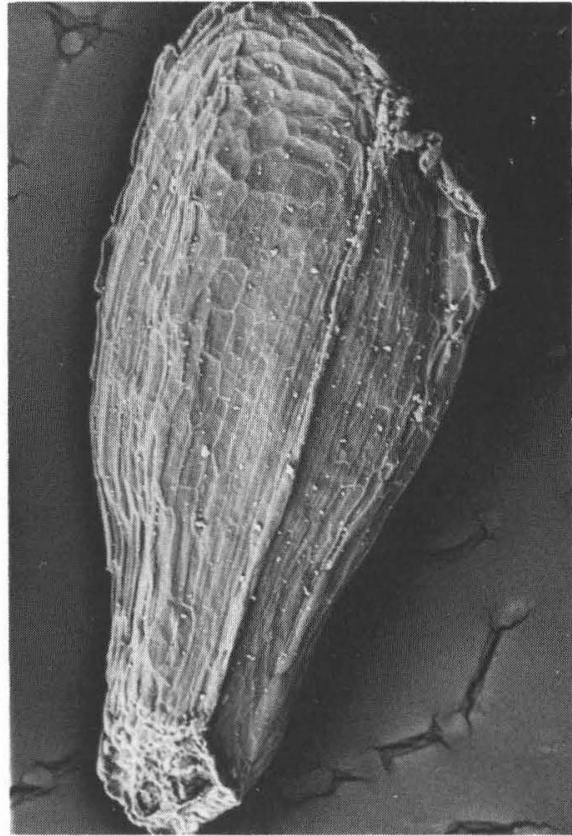

b

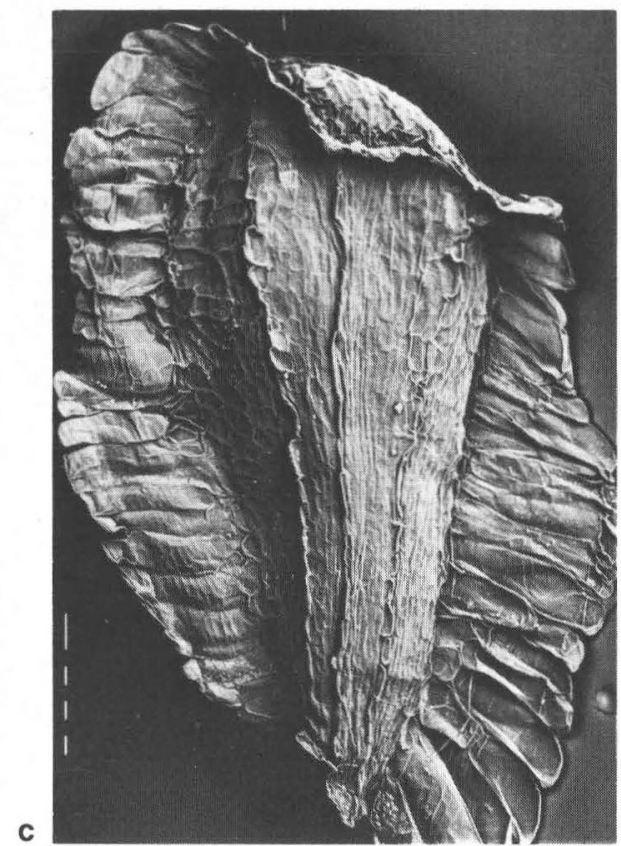

Fig. 10. Seeds. a. Irregularly cuneiform seed with inconspicuous long-reticulate pattern, L. brachyandrum. b. Ovoid-cuneiform but flattened seed with conspicuous shallow reticulation and with marginal cells extended (but not forming a distinct wing), $L$. myrsinoides. c. Ovoid-cuneiform but flattened seed with conspicuous shallow reticulation and with marginal cells forming a wing, L. laevigatum. a-c: longest bar $=100 \mu \mathrm{m}$. 


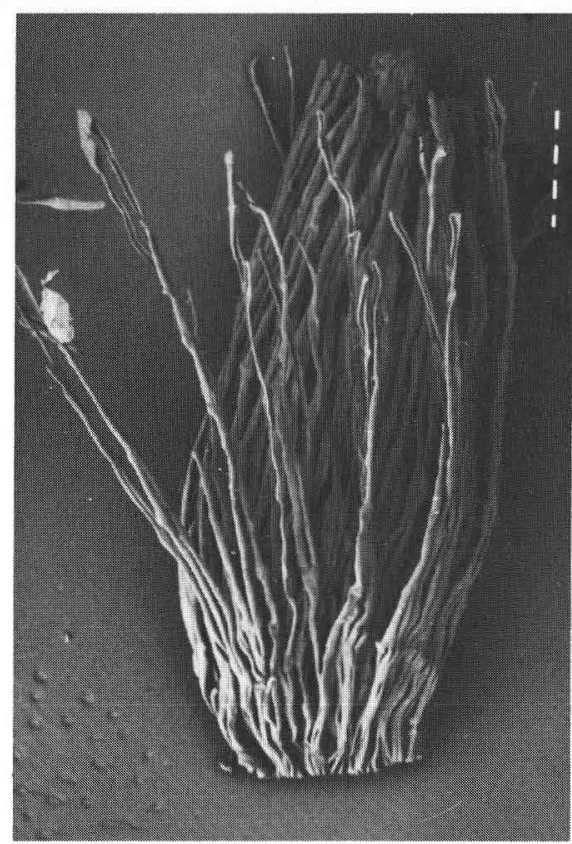

$a_{1}$

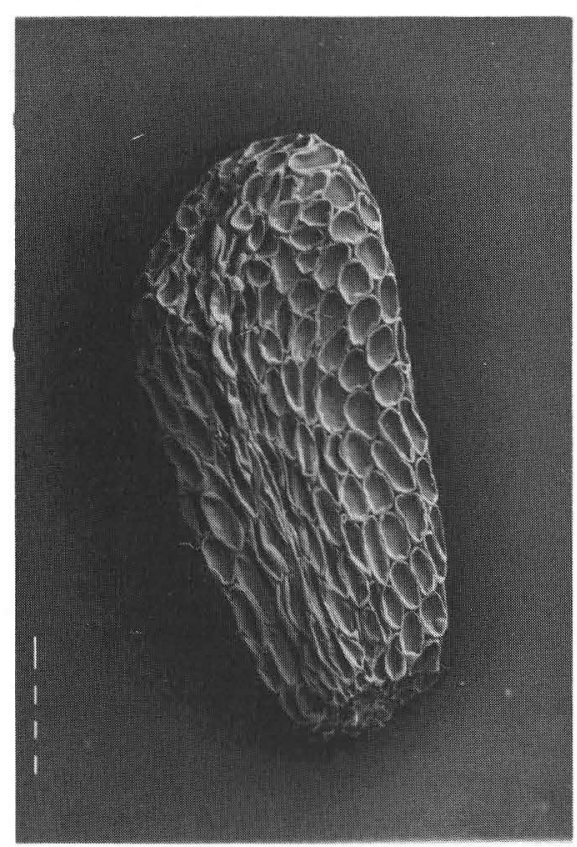

$b_{1}$

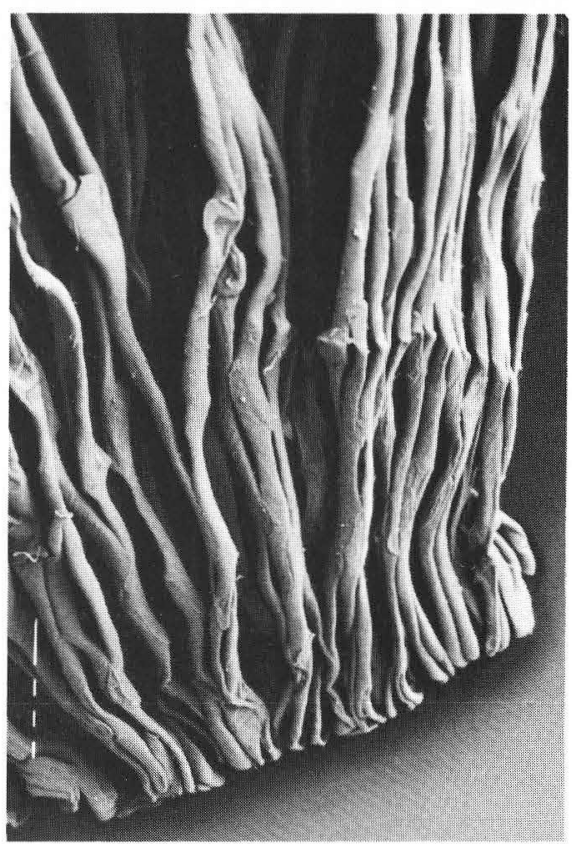

$a_{2}$

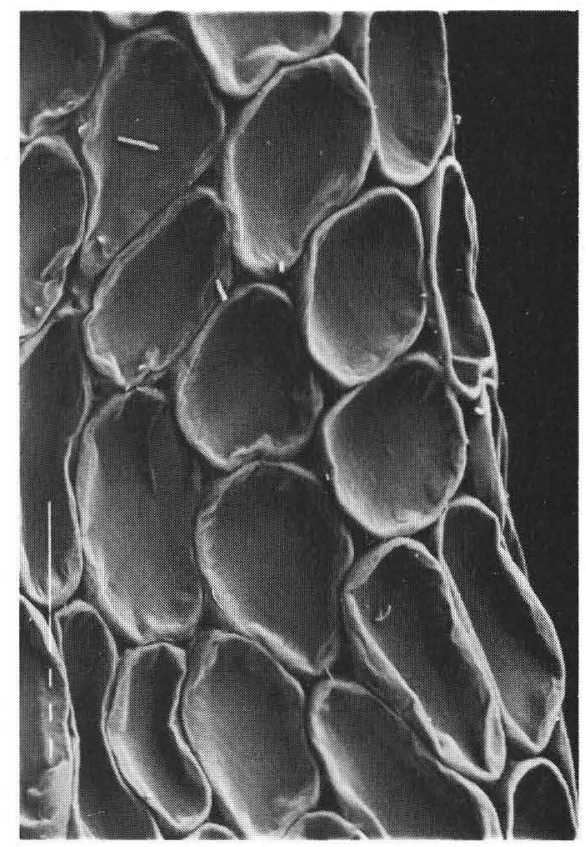

$b_{2}$

Fig. 11. Seeds. $a_{1}, a_{2}$. Irregularly oblong seed with long-reticulate pattern and with surface splitting longitudinally and lifting, L. spinescens. $\mathbf{b}_{\mathbf{1}}, \mathbf{b}_{\mathbf{2}}$. Irregularly obovoid seed with foveate-reticulate surface, $L$. multicaule.

$a_{1}$ : shortest bar $=200 \mu \mathrm{m} ; a_{2}$ : shortest bar $=100 \mu \mathrm{m} ; b_{1}, b_{2}$ : longest bar $=100 \mu \mathrm{m}$. 
Dawson (1987) has shown that eleven eastern Australian species (each with a voucher at CHR) have $2 n=22$, while $L$. myrtifolium and L. minutifolium have $2 n=44$. Smith-White found that, of fourteen eastern Australian species counted, only one, $L$. parvifolium, differed from $2 n=22$ in having $2 n=44$. The three collections of New Zealand L. scoparium (Dawson 1987) have the same count as that species in Australia, $2 n=22$.

\section{Putative natural groups}

Published infrageneric taxa do not represent any natural grouping in Leptospermum in the restricted sense accepted here (Thompson 1983; Morley \& Toelken 1983) and have not been used in this work. For practical reasons, the genus has been divided here into two informal and apparently natural groups. These groups have been further divided into subgroups, each of which assembles species that share features considered to be of diagnostic significance. The genus has not been given a formal infrageneric nomenclature here because there is still uncertainty about the placing of some taxa within this framework.

Observations and intuitive estimations of relationship are assembled in the following pages. Intuition, in this case, rests on a store of observation of characters not readily quantified, or not observed for enough species to be used for classification. The many rather anomalous species include $L$. fastigiatum, $L$. deanei, L. parvifolium, L. blakelyi, L. emarginatum, L. sejunctum, $L$. grandiflorum, $L$. rotundifolium, $L$. deuense and L. petraeum, and most of these are rare, isolated and/or little known taxa.

Although Johnson \& Briggs (1984) have developed a suggested phylogeny for the Myrtaceae, they do not distinguish between the numerous genera that are members of the Leptospermum group. The genera most closely related to Leptospermum are Kunzea, Agonis, Neofabricia, Sinoga, Pericalymma, Homalospermum and Angasomyrtus (the Leptospermum suballiance of Thompson (1983) and Johnson \& Briggs in Morley and Toelken (1983)). Leptospermum shares many features with the related genera and examination of these has influenced judgements made here, but these genera have highly modified states for many attributes that are diverse in Leptospermum.

\section{Conspectus of infrageneric relationships}

The species have been assembled in this work as follows, although not all species possess those characteristics that define their group.

1. Sepals persistent, woody fruit-valves lacking and seeds ovate with a reticulate surface Group 1.

2. Development of the terminal bud unrestricted.

3. Flowering shoots in leaf-axils

L. brachyandrum subgroup.

1. L. macgillivrayi

2. L. spinescens

3. L. oligandrum

4. L. maxwellii

5. L. exsertum

6. L. subtenue

7. L. brachyandrum

8. L. parviflorum

9. L. purpurascens 


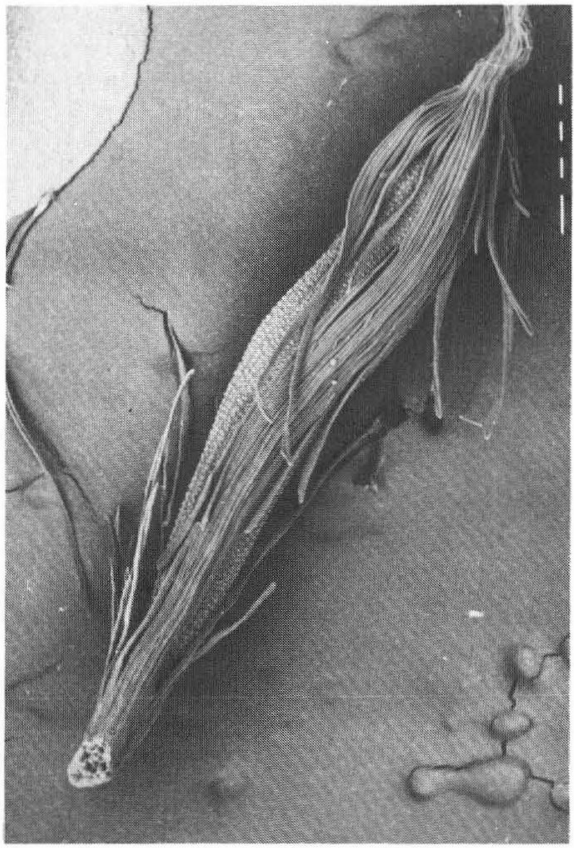

a

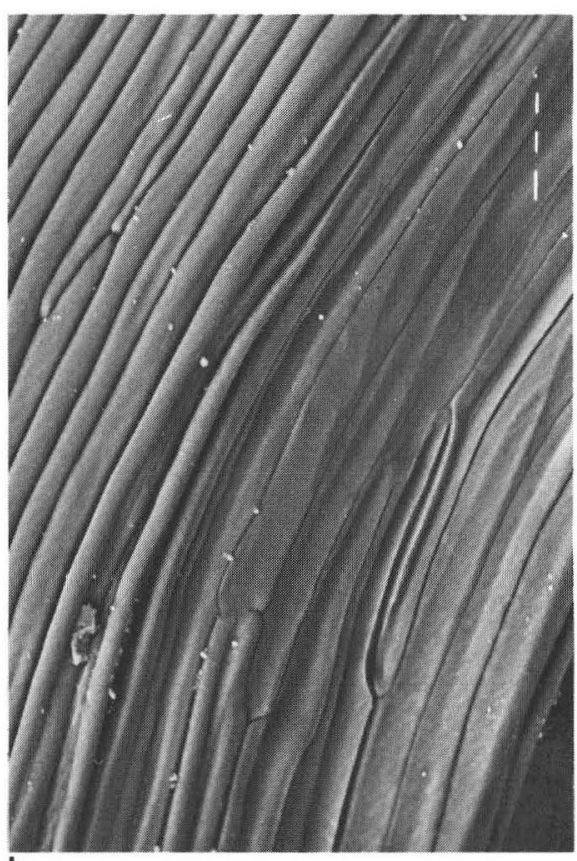

$\mathbf{b}_{2}$

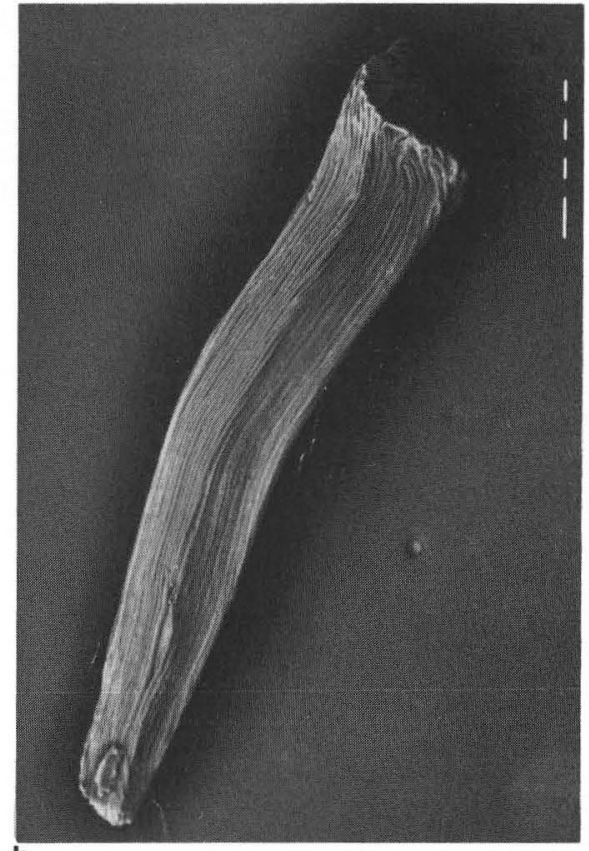

$b_{1}$

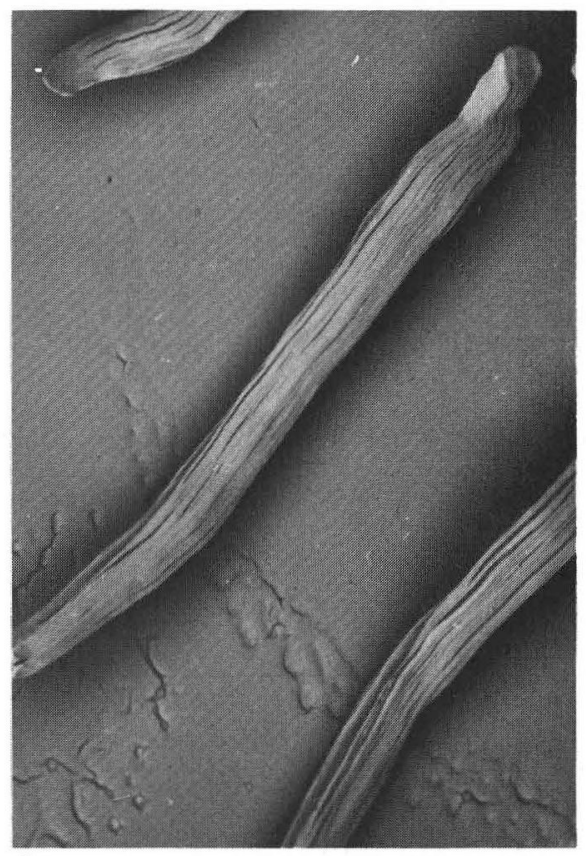

C

Fig. 12. Seeds. a. Narrowly irregularly linear seed with surface splitting longitudinally and lifting, L. polygalifolium. $\mathbf{b}_{1}, \mathbf{b}_{2}$. Linear cuneiform seed with linear-striate surface remaining on the seed, L. grandifolium. c. Narrowly linear-cuneiform seed with linearstriate surface remaining on the seed, L. rotundifolium. a, $b_{1}, b_{2}$ : longest bar $=100 \mu \mathrm{m}$; c: shortest bar $=200 \mu \mathrm{m}$. 

10. L. whitei
11. L. speciosum
12. L. luehmannii

3* Flowering shoots on shoots of a higher order L. erubescens subgroup.
13. L. erubescens
14. L. sericeum
15. L. confertum
16. L. parvifolium
17. L. deanei
18. L. semibaccatum
19. L. trinervium
20. L. subglabratum
21. L. myrsinoides
22. L. glaucescens
23. L. coriaceum
24. L. laevigatum

2* Development of the terminal bud restricted (and flowering shoots on shoots of a higher order)

25. L. nitens

26. L. roei

27. L. inelegans

28. L. incanum

29. L. fastigiatum

30. L. blakelyi

31. L. microcarpum

32. L. polyanthum

33. L. brevipes

34. L. sericatum

35. L. neglectum

36. L. lamellatum

37. L. multicaule

38. L. divaricatum L. brevipes subgroup.

1* Sepals deciduous or persistent, fruit-valves woody and seeds linear, striate Group 2.

4. Sepals deciduous and fruit-valves delicately woody.

5. Sepals pubescent near the tip L. petersonii subgroup. 39. L. emarginatum

40. L. javanicum

41. L. recurvum

42. L. wooroonooran

43. L. petersonii

44. L. liversidgei

5* Sepals glabrous 45. L. polygalifolium

46. L. morrisonii

47. L. variabile

48. L. oreophilum

49. L. novae-angliae

50. L. minutifolium

51. L. sejunctum

4* Sepals deciduous or persistent and fruit-valves strongly woody. 
6. Sepals deciduous
52. L. rupestre
53. L. myrtifolium
54. L. gregarium
55. L. obovatum
56. L. argenteum
57. L. micromyrtus
58. L. scoparium
59. L. continentale
60. L. juniperinum
61. L. rupicola
62. L. squarrosum
63. L. rotundifolium
64. L. grandiflorum

6* Sepals persistent L. lanigerum subgroup. 65. L. deuense

66. L. grandifolium

67. L. lanigerum

68. L. arachnoides

69. L. thompsonii

70. L. glabrescens

71. L. spectabile

72. L. macrocarpum

73. L. sphaerocarpum

74. L. riparium

75. L. nitidum

76. L. petraeum

77. L. turbinatum

78. L. crassifolium

79. L. epacridoideum

Some limited cladistic analyses (Thompson 1986) have been made but these groupings are not based on cladograms.

There is no assumption here that all species have been correctly assigned, but there is confidence that the scheme presented gives a framework for further observation and testing of hypotheses.

\section{Group 1}

This group contains thirty eight of the seventy nine species of Leptospermum. It, for the most part, has small fruit that lack woody valves; these rarely remain on the plant beyond the first season, and most have seeds that are, in general, ovate with a reticulate pattern on the surface.

\subsection{The L. brachyandrum subgroup}

The twelve species of this subgroup (Map 2) show a large number of presumably primitive characters, i.e. characters, that are unspecialised and shared with related genera. These characters, although not occurring in every species, include several-flowered shoots and axillary flowering shoots.

In northeastern Australia there is a relatively close-knit assemblage of six species all of which have smooth, seasonally exfoliating bark. L. parviflorum, a 

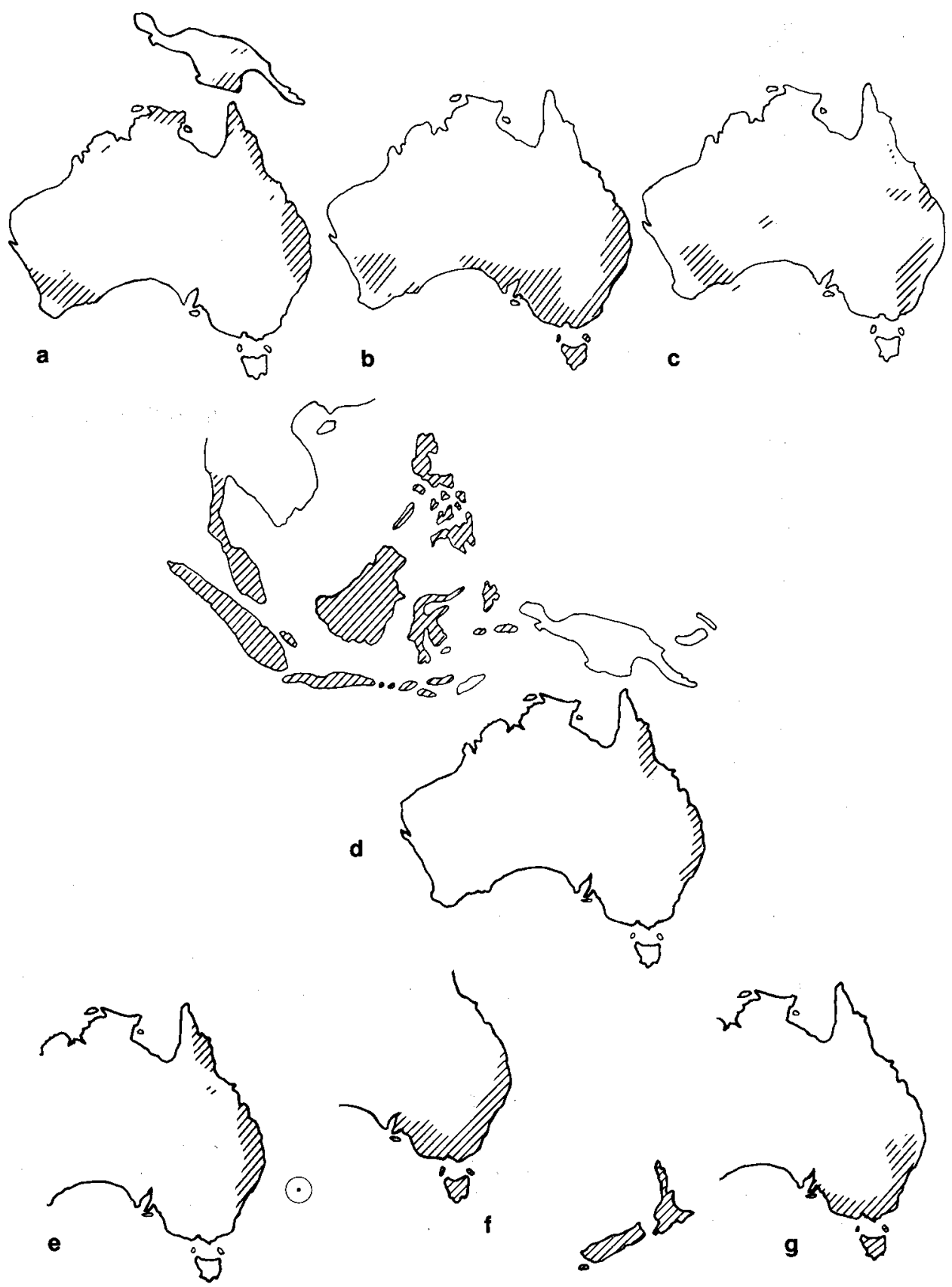

Map 2. Distribution of Group 1: a. subgroup 1 L. brachyandrum and allies. b. subgroup 2 L. erubescens and allies. c. subgroup 3 L. brevipes and allies. Distribution of Group 2: d. subgroup $1 \mathrm{~L}$. petersonii and allies. e. subgroup $2 \mathrm{~L}$. polygalifolium and allies. f. subgroup 3 L. myrtifolium and allies. g. subgroup 4 L. lanigerum and allies. 
rheophyte (sensu Steenis, 1981) is spread across tropical Australia and from the flat lands of southern Irian Jaya to northern Papua New Guinea. This species and $L$. purpurascens, occasionally showing the very primitive inflorescence condition of triads, have more apparently primitive features than the more scleromorphic L. brachyandrum (which extends southward to Port Macquarie), the allied L. luehmannii (illustrated by Beadle, 1981, as "L. brachyandrum") and the two "wallum" species, $L$. speciosum and $L$. whitei, which are sympatric with one another but differ in flowering time. The only Leptospermum in New Guinea, L. parviflorum, shows little differentiation and perhaps spread as a lowland rheophyte in the time of "ice-age aridity", at c. 17000-14000 years BP that joined these areas (Axelrod \& Raven, 1982). The fact that this species has the most primitive characters of the group possibly reflects its association with the ancestral habitat, rather than an early dispersal, and the frequent opening of Torres Strait (Kemp 1981) was probably of no significance in the timing of the dispersal.

Three species-pairs in Western Australia may have originated from rainforest (margin) ancestors formerly in Western Australia (Beadle 1966). The most specialised pair would then be $L$. macgillivrayi and $L$. spinescens (linked by a characteristic hypanthium), the former little-known, the latter highly modified. $L$. spinescens has a scattered but rather wide distribution in the southwest. Many of its features, such as woody and long-persistent fruit, parallel those of eastern groups. Similarly L. exsertum and $L$. subtenue, rare species of inhospitable habitat, are much modified, with reduced placenta-size and seed-number as are the widespread $L$. oligandrum with its much-reduced stamen-number and its satellite species $L$. maxwellii with a high placenta.

A fossil fruit found near Woomera, South Australia, in a deposit of at least Tertiary age (Lange 1978) bears a striking resemblance to the northern members of this subgroup. It is unlikely that contact between east and west was maintained after the mid-Miocene separation (Kemp 1981) by a northern route. Siliceous dunes may have supplied stepping stones at some time, but according to Kemp (1981) most of the quartz sand is Holocene.

\subsection{The L. erubescens subgroup}

This subgroup, of twelve species (Map 2), seems to be a later development with a two-stage growth unit in the flowering shoot and closer relationship between its eastern and western members than is shown in the L. brachyandrum subgroup. It includes a pair of species in the west, the widespread $L$. erubescens and the large-flowered local endemic L. sericeum, together with the less closely related $L$. confertum on East Mount Barren, Western Australia, and a group of nine species in the east that fails to reach the Tropic. The similarity of the seeds of $L$. confertum to $L$. spinescens of the $L$. brachyandrum subgroup may be convergence associated with distribution by ants.

L. glaucescens is endemic in Tasmania, whereas the modified and successful pioneer, L. laevigatum, occurs on coastal dunes from South Australia and northern Tasmania to northern New South Wales. The latter probably owes its success to an ability to tolerate calcium in the substrate, a suggestion supported by studies on Victorian dunes (Burrell 1981). Several members of this group have a rather succulent hypanthium in the fruit $(L$. glaucescens and $L$. myrsinoides of southeastern heaths, L. semibaccatum of eastern "wallum", and $L$. confertum), while $L$. laevigatum and $L$. coriaceum show a texture that could be a precursor to this state. L. trinervium and its close relative $L$. subglabratum have a "paper" bark with many layers that obviously protect the epicormic 
shoots from which these species can regenerate after fire, allowing a successful entry into dry sclerophyll forests of the eastern mainland. The widespread $L$. parvifolium is anomalous with its low placenta, very small petiolate leaves and ability to hybridise with $L$. trinervium in spite of a recorded chromosomenumber difference (Smith-White 1948), while the recently discovered $L$. deanei with its delicate fruit, though bearing some resemblance to $L$. myrsinoides and $L$. semibaccatum, cannot be linked to them by any strong feature and, being a slender tree-like shrub of creek-valley slopes, occupies a different habitat.

The two Group 1 species in Tasmania, L. laevigatum, confined there to the northern coast and islands, and $L$. glaucescens of both coastal and mountain heaths are far from primitive. L. glaucescens has most of its flowers in axillary monads, a state observed elsewhere in this genus only in reversion shoots of $L$. trinervium. The fact that $L$. glaucescens occasionally shows the flower-shoot of $L$. laevigatum and $L$. coriaceum and that it has only two rows of ovules and traces of a chemical otherwise limited to those species ( $\mathrm{P}$. Baas, pers. comm.) suggests that its axillary-flowered condition is an apomorphy, and that $L$. glaucescens is either of hybrid origin, or neotenous as to loculus-number. There is no evidence that the genus entered Tasmania before the Miocene formation of Bass Strait. That L. coriaceum has been able to move into areas inundated by both Eocene seas and the later sea incursions into the western Victorian region indicates that this species, like its close relative $L$. laevigatum, has a tolerance of calcareous traces. The apparently less closely related $L$. myrsinoides (Burrell 1981, and Parsons \& Specht 1967) lacks such tolerance and is confined to siliceous sands.

\subsection{The L. brevipes subgroup}

This subgroup is found on both sides of the continent (Map 2). All of its species except the anomalous $L$. blakelyi share a synapomorphy: restriction of the terminal bud of the flowering shoot. The characteristic appearance of this subgroup is probably associated with the relative uniformity of its inconspicuous fruit and high placenta. Many species are associated with rocky, especially granite, outcrops and escarpments. The western and eastern members have morphological similarities that are remarkable in view of their geographical separation. L. fastigiatum is the only member of the genus in very arid regions and it is somewhat anomalous, having some characteristics of the L. erubescens subgroup, and a pedicel in the fruit but not in the flower. Postulation of a hybrid origin is tempting. The four other western species form a subset. The eastern group is more diverse but $L$. brevipes adopts different forms in different regions and becomes similar to or (more likely) hybridises with the related $L$. microcarpum near the Queensland/New South Wales border. L. divaricatum, with its pungent-pointed and recurved leaves, is found in drier inland parts of the tablelands and western slopes of New South Wales, and both this species and the similar $L$. multicaule from further south have few and large seeds associated with the reduction of viable ovules in the loculus. L. polyanthum of central eastern New South Wales has a characteristic dark turgid hypanthium, L. lamellatum of inland Queensland has "paper" bark, and L. blakelyi of the Lithgow (New South Wales) district has several features (a small 2-rowed placenta, an extremely long pedicel and strangely broad divaricate branching) that obscure its origin. The mainly coastal Queensland species L. neglectum, may be less specialised than the pungent-leaved $L$. microcarpum; and $L$. sericatum on inland Queensland rock ridges may have developed in isolation from the widespread and variable $L$. brevipes. 


\section{Group 2}

Group 2 is distinguished by a woody-valved fruit that tends to remain on the plant for some years, and irregularly linear seeds with a striate surface. $L$. emarginatum could be regarded as its least specialised member, and shares with members of Group 1 the long pedicel, the readily deciduous fruit, the scarcely woody fruit-valves, the many-flowered flowering shoots, the small flowers and the small fruit. It is not known whether these are plesiomorphic, unchanged from the ancestral condition in the genus, or are cases of reversion. Such a suite of features shared with Group 1 suggests the former view. But if the latter view is taken, the connection between the two major Leptospermum groups is seen as tenuous, i.e. they could be considered to be separate genera. L. emarginatum is found southward of the main region of occurrence of the subgroup of Group 2 , regarded as most primitive, and lacks the characteristic loose fibrous bark. Being a riparian shrub it may represent a southward migration, rather than a relict of a group that has largely moved northward. Group 2 is not represented in Western Australia at all, a fact that might indicate an origin after the mid-Miocene separation within the range of the genus.

\subsection{The L. petersonii subgroup}

This subgroup of six, or possibly only five, species (Map 2) is found in warmer regions, and has spread to South East Asia where it has become established on siliceous or otherwise low-nutrient sites, especially on mountain-tops. The Asian species, $L$. javanicum, with its Mt. Kinabalu satellite $L$. recurvum, does not represent a large divergence from the presumed Australian prototype. However, it does show a pattern of variation indicative of selection on a small gene-pool, analysis of which may show the progress of its dispersal into Asia. The time of the exodus of this subgroup from Australia is unknown. Contact with the Asian plate would have allowed this in the mid-Miocene 15 million years ago but it may have been very much later. L. recurvum (illustrated by Wong, 1982, and recognised here) is little more than a vegetative variant of $L$. javanicum, although these Asian taxa are considered to occupy areas with strong evolutionary pressure (Lee \& Lowry 1980, and Axelrod 1972). The Australian species, L. petersonii of tropical Queensland and scattered occurrence to northern New South Wales, and $L$. wooroonooran of granite peaks in the region west of Cairns, share with the Asian species a tuft of hairs on each sepal as well as "stringy" bark. They also have a distinctly, though not strongly, woody fruit-valve. It is assumed that the woodiness is associated with the poor nutrient-status of the habitat, especially as frequent fire is not a factor. The related $L$. liversidgei of the "wallum" has, however, very woody fruit with reduced seed-set and an extended woody rim that does appear to have become modified for survival in its very fire-prone habitat. The style found in this latter species resembles that found in the L. scoparium subset of the L. myrtifolium subgroup and this, together with the close bark, small leaves and different habit suggests the possibility of a hybrid origin. All members of this $L$. petersonii subgroup have a character-state not seen in Group 1: deciduous, sometimes tardily so, sepals, a feature found also in other Group 2 lines. Neither the $L$. petersonii subgroup nor any other species of Group 2 are represented in New Guinea. Records for that island (Mueller 1890) have never been confirmed and obviously represent a misidentification. 


\subsection{The L. polygalifolium subgroup}

This subgroup contains seven species (Map 2). It is not strongly modified compared with the first subgroup, but shows an increase in flower size, increasing woodiness of the fruit-valves and a thinning of the texture of the sepals, at least in some species. It seems to be a group adapted more to a dry sclerophyll habitat than the generally more wet sclerophyll $L$. petersonii subgroup, so that in this and other advanced groups larger leaves could be considered an adaptation to a riparian habitat. No extant species of the subgroup could be considered more primitive than another, most having autapomorphic specialisations, especially modified anthers, with the little-known $L$. sejunctum anomalous as to anthers, a non-inset style and a high placenta. Further collections of $L$. sejunctum may reveal features enabling it to be placed elsewhere or showing it to be of hybrid origin. The other species of this subgroup are linked by their modified anther-cells that are deep, fail to open widely, and also tend to diverge so that the ends or even the whole cells move apart. Least modified are $L$. variabile and $L$. oreophilum, species of misty coastal mountains. More modified, with obvious cell-divergence and with the seed-surface splitting so that the seed-ends are capped with parasols of fibres, are the widespread and successful species $L$. polygalifolium, which has diverged into six subspecies (one on Lord Howe Island and one in the tropics), and L. morrisonii, almost sympatric with $L$. polygalifolium in central eastern New South Wales but on a substrate with more available nutrient. A third pair of species is found on low-nutrient soils of the northern tablelands of New South Wales: L. minutifolium with very small leaves and disproportionately small petals, and $L$. novae-angliae, very variable and little-known but often with thick and pungent-pointed leaves, apparently an adaptation to the stresses of climate and poor soils of the region. It is tempting to think of this subgroup as having arisen in the southern part of its range and migrated northward, with the success of $L$. polygalifolium being associated with the more open savannah developing in the Pleistocene.

\subsection{The L. myrtifolium subgroup}

The subgroup of thirteen species around L. myrtifolium (Map 2) is much more diverse in general appearance than the two previous subgroups, and has much woodier fruits, a character that perhaps allows recovery from fire, though most species occupy habitats in cool climates that are not particularly fire-prone. Their habitats require an ability to survive periods of low water-availability and most of these species have rather thick leaves, often relatively broad, and some have pungent-pointed leaves. Perhaps the ancestral taxon resembled $L$. obovatum. This species is certainly similar to the two previous subgroups in many ways. It is generalised in its appearance and has the development of its terminal vegetative bud restricted, as in some of the $L$. petersonii subgroup, and it lacks the specialised anthers of the $L$. polygalifolium subgroup. It has spread widely (with some leaf-shape variation) in riparian habitats and reached subalpine altitudes $(1620 \mathrm{~m})$ in the Kosciusko area. Apart from this species there appear to be three main lines of development. One has a mostly highaltitude distribution, with $L$. rupestre on Tasmanian mountains, $L$. micromyrtus on granite mountains of the southeastern mainland, and $L$. myrtifolium, L. argenteum and L. gregarium in swamps and on creekbanks of the southeastern mainland, Barrington Tops region and northern tablelands of New South Wales respectively. It is likely that the small-celled anthers of $L$. rupestre and L. myrtifolium represent a reduction from the large-celled state usually found in Group 2 species. The second line in this subgroup is unified by its pungent-pointed leaves. One species, $L$. juniperinum, has been successful 
along the eastern mainland coast in sandy swampy soils and has reached southern Queensland. Two others, $L$. rupicola of cliff-faces and $L$. squarrosum of skeletal sandstone soils, are found in central eastern New South Wales, while another, L. continentale, is widespread from South Australia to central New South Wales, often in open swampy habitats but able to survive a lowering of the water-table. $L$. scoparium, very variable in Tasmania and the only representative of the complex there, may have differentiated there and subsequently re-invaded the mainland forming scattered populations showing different facies. It appears the least specialised of the pungent-leaved species. Some collections from southern Victoria seem to represent a breakdown of $L$. scoparium and $L$. continentale, perhaps as a result of recent trans-Bass Strait migration of propagules of $L$. scoparium. $L$. scoparium has been very successful in Tasmania and has migrated across the Tasman Sea to New Zealand. In New Zealand it is the only species of Leptospermum (the species previously known as L. ericoides is now considered a Kunzea (Thompson 1983)), and, being a far from primitive Leptospermum, cannot be an ancient Myrtaceous plant of the New Zealand Palaeocene as has been assumed in that country (Fleming 1975). It must be a relatively recent arrival by long-distance dispersal. It is likely that on arrival in New Zealand $L$. scoparium became established in limited edaphically suitable areas until the arrival of Polynesian man whose fire and forest-clearing brought about those low-nutrient-status conditions for which it had been pre-adapted in its homeland. Burrell (1965) reports fruit of $L$. scoparium opening within an hour of passage of a fire. The continued deterioration in the fertility of its habitat in New Zealand has been much to its advantage (Ronghua et al. 1984) allowing it to become a significant part of that country's flora. The occurrence of variants, of much interest to horticulture, in New Zealand suggests a small gene pool and expansion into new areas, and there is already indication of regional divergence. Whether this is a significant genecological differentiation will need to be confirmed by further study and transplantation, given the plasticity of vegetative features in the species (Burrell 1965, Ronghua et al. 1984).

A further pair of species may fall within this group, the local endemic $L$. grandiflorum on the granite of the Tasmanian east coast and L. rotundifolium of sandstone escarpments of southeastern New South Wales. Both species have very large and beautiful flowers and large seeds in very woody fruit. They seem to have much in common but whether they form a natural group is unclear. It is possible that $L$. rotundifolium, resembling in its style-base and chemistry (Flynn et al. 1979) L. macrocarpum of the L. lanigerum subgroup, is of hybrid origin.

The time of the entry of the Tasmanian members of the L. myrtifolium subgroup, or their precursors, to that region is a matter for speculation. The habitat of $L$. rupestre requires it to have moved into its present sites after the last glacial retreat, while the spread of $L$. scoparium was probably the result of aboriginal firing of the region.

\subsection{The L. lanigerum subgroup}

This is a further subgroup of woody-fruited Leptospermum species (Map 2) that is quite distinct from those dealt with so far. It is characterised by lack of any sign of abscission in the sepals, which remain in place on the fruit until time wears them away (a condition general in Group 1 and hence possibly primitive) and by the complete lack of any stem-flanges, a feature rarely absent from other 
woody-fruited species. With features awkwardly between this subgroup and the troublesome last pair, $L$. rotundifolium and $L$. grandiflorum of the $L$. myrtifolium subgroup, is $L$. deuense. This is a species recently discovered on a rhyolite cliff in the wilderness of the upper reaches of the Deua (Moruya) River of south coastal New South Wales. It resembles the former group in having a stem-flange, but seems to have persistent sepals. All other species have persistent and deltoid sepals, reduced flanges, and 1-flowered flowering shoots.

Within the subgroup are several obvious lines. In one of these, L. lanigerum, a southern species common in Tasmania and extending to South Australia and central New South Wales, is similar to L. grandifolium of Victoria and New South Wales but has a different pattern of leaf-variation and a very different bark type. A trio of species, L. thompsonii, L. glabrescens and L. arachnoides, seem to be linked (with short sepals and similar branching). L. arachnoides is pungent-leaved, has reduced flower- and fruit-size and extends from southern New South Wales to the Queensland border, the more generalised $L$. thompsonii is limited to the Monga area of the New South Wales tableland escarpment, and L. glabrescens is found only on the Recent sands of East Gippsland, Victoria. The latter's hemispherical sepal links it to L. thompsonii and its characteristic divaricate branching to $L$. arachnoides. Also sharing a rather striking set of characters are $L$. spectabile, with red flowers and very large fruit, L. macrocarpum with even larger fruit and its flowers sometimes red, and $L$. sphaerocarpum whose fruit is atypical for the genus (in being deeper than broad) and often has fewer loculi. These species share a style-character: the ovary surface adheres to a style base which is not inset. Flynn et al. (1979) associate the essential oils of $L$. macrocarpum and $L$. sphaerocarpum and dissociate them from those of "L. lanigerum" (probably L. grandifolium).

There is a further subset of six species linked by the character-state of longdeltoid sepals. This is a group of highly modified species geographically isolated from one another. One pair, $L$. crassifolium and $L$. epacridoideum have adjacent ranges in south coastal New South Wales and their leaves are similarly thick and glossy. L. nitidum is widespread in Tasmania (especially the west) and extends to Bass Strait islands; characterised by a flat-topped fruit, it has been most successful in the fire-ravaged mountains. L. riparium of Tasmania lines the rivers of the cool rainforest region (Jarman \& Brown 1983). $L$. turbinatum with its obconical fruit base is confined to ranges in western Victoria, while $L$. petraeum is known only from a small granite tor, "Rocky Top", near Kanangra, New South Wales, and a specimen labelled "Blackheath" in the New South Wales herbarium.

\section{Evolution and dispersal}

The pattern of relationship between the extant species of Leptospermum is consistent with an origin in warm, moist, south-central regions just before the continent experienced increasing aridity. The three subgroups of Group 1 would then represent successive waves of expansion from that area of origin. Group 2 probably arose in the eastern part of the original range and was prevented from moving westward by changed environmental conditions. The pattern also suggests that a decrease in available nutrient in the habitat and an increase in the frequency of fire encouraged the development of species able to use the dwindling resources of a harsh environment (Stebbins 1952). The most "xeromorphic" leaves of the genus are not those of inland species but of species that have moved into the nutrient-poor uplands of southeastern Australia. In 
spite of the long-published opinions of Beadle (1966) that scleromorphy is associated with lack of nutrient rather than lack of water, one still finds authors such as Johnson (1980) trying to explain the morphology of these largely swamp species as being due to xeric conditions.

The Quaternary (Axelrod 1979) change to a mediterranean climatic regime in the west of Australia has not been associated with any morphological states not seen in the east, where members of the genus were not subjected to this change. The spiny branches of $L$. spinescens may be an exception. As Beard (1982) indicates, the distribution of scleromorphic species must have been very greatly influenced by man's use of fire. The original speciation, however, must have been associated with the fragmentation of ancestral ranges by natural phenomena (James \& Hopper 1981).

From the few chromosome counts available there is little enlightenment as to the basic condition. One could assume an ancestor with $n=11$, the general base-number in Myrtales, allowing an increase to $n=22$ when taxon speciesnumbers are reduced by environmental influences as suggested for species in general by Löve and Löve (1971), or as an adaptation to extreme climate. Such counts as are available do not show $n=11$ to be associated with species considered to have most ancestral features.

In many, perhaps all, species of Leptospermum many flowers lacking female parts are to be seen. From herbarium material this is difficult to detect and the proportion of these flowers on individual plants, or in particular species, impossible to assess. The phenomenon has been documented as occurring in a number of other genera of the family, as by Carr et al. (1971), and the "adaptive significance" of this facultative andromonoecy has been studied in New Zealand populations of $L$. scoparium by Primack \& Lloyd (1980, 1980a). It is general in the genus, and widespread in the plant community generally. The influence of environmental factors and nutrition on sex determination in plants is reviewed by Chailakhyan \& Khrianin (1987). Monitor (1981) cites work showing that sex-change can be observed in many plants, including $A s$ paragus officinalis and Spinacea oleracea, that environmental stress causes maleness, and that shortage of water increases cytokinins which increase maleness. He concludes that it is the ability to change that gives the advantage, and this facility may have enhanced the ability of many Leptospermum species to invade areas unsuited to more demanding plant species.

There is little to cast doubt on the hypothesis that the genus achieved an early broad range in Australia, followed by differentiation, a central extinction and a northern and southern extension in the east, as a theoretical outline of how evolution produced the genus Leptospermum that we see today. There is no definite fossil evidence other than the Woomera fruit to confirm or deny such speculation. There is, however, an alternative explanation of the variation and disjunction observed. Perhaps in Leptospermum we have a group evolving so rapidly that many of these apomorphies are quite recent.

Many species of Leptospermum are extremely variable, but not all the variation is of the same nature. Some seems to be caused by a large phenotypic response (in stature, the degree of andromonoecy, flower- and fruit-size, and initiation of fruit-valve opening) to relatively minor variation in the environment. Other variation is obviously of genetic origin, with a rapid response to selection that is apparently readily reversible. This is seen in species like L. grandifolium where the facies is different depending on habitat, especially as to the shady river margins and sunny river beds of montane regions of its range. Some 
species, however, carry variation, at present unexplained, that allows polymorphy within populations. This is the pattern found in L. trinervium, where a number of features vary, either associated or dissociated, between and also within populations. These three variation-phenomena are probably similar to those that have allowed the genus to take advantage of the many, though rather slight, oscillations of climate in the eastern Australia of the Quaternary, allowing fixation of species after their isolation.

The success of this genus is probably tied to its ability to colonise rapidly an area left untenanted for any reason, provided that area has low available nutrient. Certainly $L$. glabrescens has occupied the recent new accretions of coastal Gippsland. L. scoparium has spread rapidly in New Zealand where man has cleared forests and altered the environment (Mohan et al. 1984; Ronghua et al. 1984). L. laevigatum has been planted by sand-miners and local councils and is extending along coastal sand beyond its natural, but no doubt pioneering, limits.

Sterility barriers do not seem to have had much time to develop. Herbarium records (especially those of NSW where workers for a century or more have collected puzzling specimens of Leptospermum) show many hybrids. This phenomenon is probably for the most part associated with the recolonising of cleared land, and therefore not a reflection of natural conditions, but there is a real possibility of gene-flow between rather remotely related species under some conditions, demonstrating a lack of development of barriers. A number of species that remain distinct though sympatric through much of their range, break down in certain areas, and may have done so in the past. Although all these species are not distant in relationship, many wide crosses have been observed. Species-breakdown has been noted in the field and recognised in herbarium collections between L. gregarium and L. polygalifolium subsp. transmontanum (on the Northern Tablelands of New South Wales), $L$. myrtifolium and L. obovatum (on the Central Tablelands of New South Wales) and $L$. myrtifolium and $L$. continentale (in several regions). As well, natural hybrids have been found between $L$. laevigatum and $L$. myrsinoides, $L$. parvifolium and $L$. squarrosum, $L$. arachnoides and $L$. squarrosum, $L$. juniperinum and L. polygalifolium, L. grandifolium and L. sphaerocarpum, and $L$. nitidum and $L$. lanigerum. $L$. emarginatum and $L$. petersonii have been found to hybridise in cultivation. Unusual specimens from the New England district of New South Wales are thought to be $L$. novae-angliae $\mathrm{x} L$. gregarium and $L$. minutifolium $\mathrm{x} L$. polygalifolum, and it is likely that other unidentified specimens are of hybrid origin. This could indicate close relationship in the recent past, recent spread of one of the taxa concerned, or that man's alteration of previously distinct habitats has affected species that lack barriers to interbreeding. In South Australia and western Victoria, especially southward of the Grampians, there are populations of $L$. lanigerum that have excited comment and earned the name "Green Teatree". Genes from another species seem to have invaded, but failed to dominate, the local species. It is possible that these genes are from the endemic Tasmanian L. nitidum and that occasional invasions across Bass Strait have modified some of the local L. lanigerum. These species are known to hybridise in Tasmania though they belong to distinct subsets within their group. 


\section{Generic Description}

Leptospermum Forst. et Forst. f. Char. Gen. Pl. 71, t. 36 (1776)

LECTOTYPE: L. scoparium, fide McVaugh, Taxon 5: 142 (1956).

Glaphyria Jack, Trans. Linn. Soc. London 14: 128 (1823). LeCtOTYPE here chosen): G. nitida Jack (following Merrill, J. Arnold Arbor. 33: 226 (1952) who equated Glaphyria and Leptospermum).

Macklottia Korth., Ned. Kruidk. Arch. 1: 196 (1847). LECTOTYPE (here chosen): $M$. javanica (Blume) Korth.

Leptospermopsis S. Moore, J. Linn. Soc., Bot. 45: 202 (1920). TyPE: L. myrtifolia S. Moore.

Shrubs or trees with smooth and flaking, fibrous or papery bark. Leaves alternate, usually no more than $1 \mathrm{~cm}$ long, often variable in shape (within the species) but mostly almost elliptic with the broadest part above or below the middle, the apex various, the base sessile or shortly petiolate and often varying within the species, the margins entire and the surface variously curved, often recurved and incurved in different parts of the same leaf; texture often thick or firm; often aromatic, occasionally lemon-scented. Stipules minute and usually seen only about the flowers. Flowers 2-bracteolate, often pedicellate, axillary in bract-axils on condensed shoots or, rarely, as monads in leaf axils, actinomorphic. Hypanthium obtuse or variously tapered at the base and, in the upper part, erect or spreading at anthesis. Sepals 5, imbricate, persistent or deciduous. Petals 5, spreading, conspicuous, deciduous, white, pink or red. Stamens usually shorter than the petals, in 5 antepetalous groups but appearing free, and spread evenly along the rim of the hypanthium; anthers opening by slits, versatile, with a conspicuous gland near the connective and a thickened area at the base of each cell. Style simple, usually with the base inset in a depression in the ovary summit; stigma entire or occasionally somewhat lobed. Ovary (2-)3-5 or more -locular with the placenta axile and usually just above the middle of the central axis. Ovules few to numerous, anatropous. Fruit a rigid or woody capsule with valves opening at the top. Seeds somewhat ovoid, with the testa reticulate, occasionally ridged or winged; or irregularly linear and striate. $n=11,22$.

In most references to individual species of Leptospermum in standard works, and in the many papers dealing with attributes of members of this genus, the identity of the taxon has been confused or is unknown. Reinterpretation is difficult when the author's concept of species was as generalised as in S. Schauer (1841), Domin (1928) and Cheel (1943), or when the specimen citations were edited as in Bentham (1867). Geographic limitations will in many cases draw attention to these incorrectly used names. Unfortunately, we must accept the fact that past generalisations about members of this genus have been based on specimens whose correct identity, even as to genus, is often in doubt, and that all past vouchers must be reidentified in the light of our new, though still imperfect, knowledge.

I have traced the original descriptions of almost all published names and included these names in the relevant synonymy, but the subsequent usage of these names has mostly been other than as represented by their Types (often with usage differing with the institution or standard work). It has proved quite impossible to allot to the correct species the disparate elements in most other 
references. In many cases an "intelligent guess" would place the published names in the synonymy of the correct species but it was "intelligent guesses" by writers such as Bentham, Smith, J. D. Hooker, Domin and Cheel that brought about the nomenclatural chaos that has characterised this genus and its close relatives.

\section{Key to species}

1 Fruit not woody, or if so then the valves not woody, or the outer part of the fruit smooth and rather fleshy, or the plant spinescent. The seed surface usually with a rugose-reticulate pattern $[1 *$ p. 343] . . . . . . . . 2 .

2 Branches spinescent. Fruit woody, often more than $1.5 \mathrm{~cm}$ diameter, and long-persistent . . . . . . . . . . . . . . 2. L. spinescens

2* Branches not spinescent. Fruit not large, woody and long-persistent . . 3 .

3 Sepals cream-coloured and thin. Filaments very narrow and thread-like $\ldots \ldots \ldots \ldots \ldots \ldots \ldots \ldots \ldots \ldots \ldots \ldots \ldots \ldots \ldots \ldots$. L. macgillivrayi

3* Sepals never uniformly thin and cream-coloured. Filaments broad in the lower part or almost linear; stout or slender, but never fine and thread-like

4 Fruit-base firm or chartaceous. Valves with margins variously pubescent or glabrous, but if (rarely) the loculi more than 5 , the open edges pubescent [4*. p. 343]

5 Leaves c. $1 \mathrm{~cm}$ long with the margins strongly recurved when dry $\ldots \ldots \ldots \ldots \ldots \ldots \ldots \ldots \ldots \ldots . \ldots \ldots$. L. purpurascens

5* Leaves various but never as above; if the margins somewhat recurved, the leaves at least $1.5 \mathrm{~cm}$ in length $\ldots \ldots \ldots \ldots \ldots \ldots \ldots \ldots . \ldots \ldots$

6 Most flowering shoots condensed and with more than 2 flowers. Fruit consistently 3 -locular. Leaves much longer than broad . . . . . . 7 .

7 Leaves tapering to a slender apex; the leaf-surface not glossy . . . . 8 .

8 Leaves tapering to a narrow base, or if somewhat broad-based then the anthers c. $0.25 \mathrm{~mm}$ long $\ldots \ldots \ldots \ldots \ldots \ldots \ldots \ldots \ldots \ldots \ldots . \ldots \ldots$.

9 Leaves thin in texture with the margins more or less recurved

8. L. parviflorum

$9^{*}$ Leaves firm in texture, and flat $\ldots \ldots \ldots \ldots \ldots \ldots \ldots \ldots . \ldots \ldots$.

10 Hypanthium glabrous or almost so. Leaves linear-lanceolate $\ldots \ldots \ldots \ldots \ldots \ldots \ldots \ldots \ldots \ldots \ldots$. . . . brachyandrum

10* Hypanthium pubescent. Leaves elliptical

10. L. whitei

8* Leaves broad-based. Anthers c. $0.5 \mathrm{~mm}$ long . . . . 11. L. speciosum

$7 *$ Leaves with a broad, rounded apex; the leaf-surface glossy $\ldots \ldots \ldots \ldots \ldots \ldots \ldots \ldots \ldots$. . . . . . . . . . . . . . . . . . . . . . . . . . . . . . . . . . .

6* Flowers on most flowering shoots $1-2$; if occasionally more then the loculus-number of the fruit varying from 3 to 5 . Leaves various . . . 11.

11 Fruit with glabrous long-exserted valves extending to the top of the long, erect sepals and a pubescent base much shorter than the valves 
$11^{*}$ Fruit not as above

12 Leaf-apex blunt or with a short blunt point, or, if with a very short pungent point, the leaves subtending the flowering shoots not both infolded or incurved and reflexed [12*: p. 342]

13 Flowers borne at the ends of branches bearing very small, obtuse, petiolate leaves. Hypanthium usually with spreading hairs $\ldots \ldots \ldots \ldots \ldots 14$.

14 Placenta high in the top of the flat-topped loculus. Petiole broad $\ldots \ldots \ldots \ldots \ldots \ldots \ldots \ldots \ldots \ldots \ldots \ldots \ldots \ldots \ldots \ldots$ 6. $L \ldots \ldots$ subtenue

$14^{*}$ Placenta low, with the loculus extending far above it. Petiole slender 16. L. parvifolium

$13^{*}$ Flowers usually on side-shoots shorter than the subtending leaf, but if on longer shoots then the leaves not very small, obtuse and petiolate. Hypanthium variously pubescent $\ldots \ldots \ldots \ldots \ldots \ldots \ldots \ldots \ldots \ldots \ldots .$.

15 Filaments with hairs at least in the lower part. Hypanthium mostly glabrous but with dense silky hairs on the pedicel .... 17. L. deanei

$15^{*}$ Filaments glabrous, or if with hairs on the lower part then the hypanthium and pedicel completely glabrous $\ldots \ldots \ldots \ldots \ldots \ldots \ldots \ldots \ldots \ldots$

16 Hypanthium pubescent or glabrous, but if glabrous then tapering to the base or with sepals of different texture or $1 \mathrm{~mm}$ or more in length [16*:

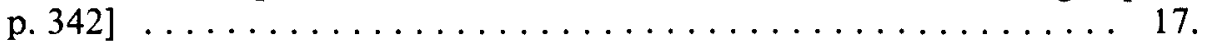

17 Leaf-bud of the flowering shoot expanding with or just after the associated flower or flowers. Hypanthium with or without a pedicel [17*: p. 342]

18 Fruit 5-locular, 3-5-locular or, if consistently 3-locular, the valves not much exserted and the style-base not inset in the apex of the fruit-valve

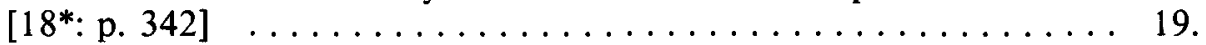

19 Fruit-valves extending above the hypanthium as the fruit opens [19*: p. 342]

20 Upper surface of the fruit disproportionately raised near the style-base

21 Fruit (including the stalk) usually as broad as long, with a conspicuous rim formed by the erect hypanthium-top $\ldots \ldots \ldots \ldots$ 13. L. erubescens

$21^{*}$ Fruit (including the stalk) usually longer than broad, with the hypanthium-

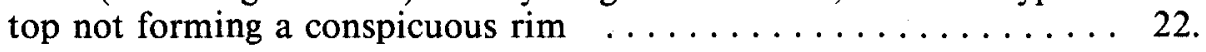

22 Hypanthium tapering rather abruptly to a narrow pedicel. Placenta not high in the loculus, the ovules c. 20 in 4 rows .... 3. L. oligandrum

$22^{*}$ Hypanthium tapering gradually to a narrow pedicel. Placenta high in the loculus with the ovules usually $4-12$ in 2 rows ..... 4. L. maxwellii

$20^{*}$ Upper surface of the fruit evenly rounded $\ldots \ldots \ldots \ldots \ldots \ldots 23$.

23 Leaves usually $1 \mathrm{~cm}$ or less in length. Flowers on the flowering shoot usually 1 . Upper bracts retained on large buds and usually persisting about the flowers $\ldots \ldots \ldots \ldots \ldots \ldots \ldots \ldots \ldots$ 34. L. sericatum

$23^{*}$ Leaves usually more than $1 \mathrm{~cm}$ long. Flowers on the flowering shoot 1 or 2 . Upper bracts shed from young buds and not seen about the flowers . 24 . 
24 Leaves obtuse or shortly acuminate. Bark close 33. L. brevipes

$24 *$ Leaves tapering to the apex. Bark on older branches and trunk in many flaky layers

36. L. lamellatum

19* Fruit-valves not or scarcely extending above the hypanthium as the fruit

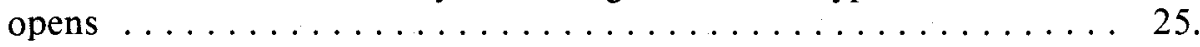

25 Most fruit at least $4 \mathrm{~mm}$ in diameter. Anther-cells usually more than 0.5

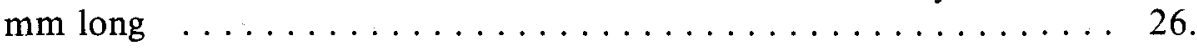

26 Hypanthium pubescent all over, rarely all glabrous; the top not incurved

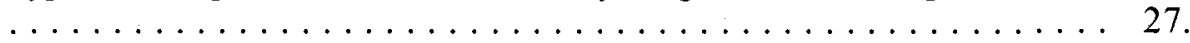

27 Stems with the bark firm and rather corrugated

14. L. sericeum

$27^{*}$ Stems with many layers of flaky bark

19. L. trinervium

$26^{*}$ Hypanthium glabrous or with a dense silky pubescence at the base, the top curved over the edge of the fruit $\ldots \ldots \ldots \ldots \ldots$ 20. L. subglabratum

$25^{*}$ Fruit less than $4 \mathrm{~mm}$ in diameter. Anther-cells $0.5 \mathrm{~mm}$ or less in length

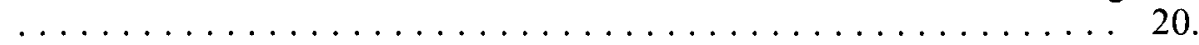

28 Fruit (including the stalk) as long as or longer than broad 29.

29 The upper part of the hypanthium folded over the top of the fruit

27. L. inelegans

$29^{*}$ The upper part of the hypanthium not folded over the top of the fruit 30.

30 Hypanthium with dense spreading long hairs 26. L. roei

$30^{*}$ Hypanthium with an appressed pubescence 31.

31. Hypanthium very broadly expanded in the upper part and tapering gradually to a tapering and long (to $3 \mathrm{~mm}$ or more) pedicel .. 28. L. incanum

$31^{*}$ Hypanthium expanded broadly but not further expanded in the upper part; the base tapering gradually, or more suddenly, to a pedicel of usually less

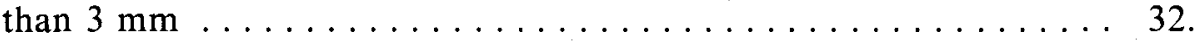

32 Young stems not tuberculate. Hypanthium in the flower tapering suddenly below the ovary to a pedicel $\ldots \ldots \ldots \ldots \ldots \ldots \ldots 25$. L. nitens

$32^{*}$ Young stems usually covered with tubercles. Hypanthium in the flower gradually tapering to the base $\ldots \ldots \ldots \ldots \ldots \ldots$ 29. L. fastigiatum

$28^{*}$ Fruit very broad and shallow above a very short stalk . 35. L. neglectum

$18^{*}$ Fruit consistently 3-locular, the valves much exserted and each notched slightly at the apex by the scarcely inset style ..... 37. L. multicaule

$17^{*}$ Leaf-bud of the flowering shoot precocious so that flowers are found at the base of shoots and even of branched shoots. Hypanthium tapering to a very long slender pedicel

30. L. blakelyi

$16^{*}$ Hypanthium glabrous, or only very slightly pubescent, with short sepals, c. $0.7 \mathrm{~mm}$ long, of the same texture; the base broadly and abruptly rounded above a short pedicel $\ldots \ldots \ldots \ldots \ldots \ldots \ldots$ 32. L. polyanthum

$12^{*}$ Leaf-apex with a stiff pungent point $\mathrm{c} .1 \mathrm{~mm}$ long, the leaves subtending the flowering shoots infolded or incurved, and reflexed ......... 33 . 
33 Sepals obtuse, short-oblong to hemispherical. Ovary 3-5-locular, each loculus with more than 20 ovules

31. L. microcarpum

33* Sepals acute, deltoid. Ovary 3-locular and each loculus with 20 or fewer ovules

38. L. divaricatum

4* Fruit-base succulent or, when dry, coarsely wrinkled as if previously succulent. Valves densely pubescent on the open edges or, if sparsely so, then the loculi more than 5 34.

34 Ovules in each loculus c. 20, in 4 or more rows. Loculi 3-5 . . . . 35 .

35 Sepals long-deltoid, about twice as long as broad. The central stamen less than $1 / 2$ the petal-length $\ldots \ldots \ldots \ldots \ldots \ldots$ 18. L. semibaccatum

$35^{*}$ Sepals very shortly deltoid, $0.5 \mathrm{~mm}$ long, and usually broader than long. The central stamen c. $2 / 3$ the petal-length $\ldots \ldots \ldots$ 21. L. myrsinoides

$34^{*}$ Ovules in each loculus c. 10 , in 2 rows on a narrow placenta. Loculi rarely

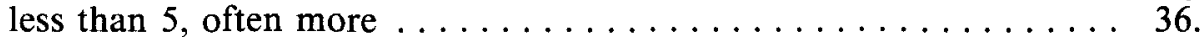

36 Sepals deltoid and rather scarious, usually pubescent at least in part. Leaves

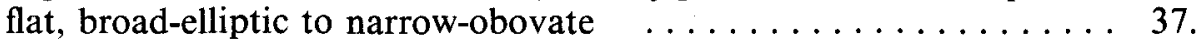

37 Many flowers axillary and solitary (not subtended by bracts). Fruit usually 4-5 $\mathrm{mm}$ in diameter

22. L. glaucescens

$37^{*}$ Flowers on a condensed leafless axillary shoot enclosed by imbricate bracts in the bud. Shoot with 2 flowers developing. Fruit usually more than $5 \mathrm{~mm}$

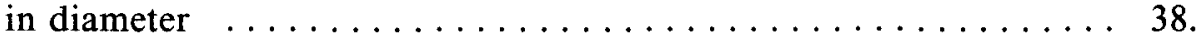

38 Leaves usually light yellowish green and narrowly obtuse, acute or acuminate. Fruit usually $4-7$ locular ......... 23. L. coriaceum

38* Leaves usually grey-green and broadly obtuse. Fruit usually 6-11-locular 24. L. laevigatum

36* Sepals almost hemispherical, thick, obtuse and incurved, glabrous. Leaves very narrowly clavate (c. $1 \mathrm{~mm}$ broad) and somewhat triquetrous

15. L. confertum

$1^{*}$ Fruit woody and never succulent; with woody valves that often remain unopened for some time. Plants never spinescent. The seed surface with fine longitudinal striations $\ldots \ldots \ldots \ldots \ldots \ldots \ldots . \ldots \ldots$. . . . . . . . . .

39 Sepals readily deciduous or if tardily deciduous the leaves lemon-scented and/or the stem-flange conspicuous [39*: p. 345] . . . . . . . 40.

40 Anther-cells broader than deep (when open) and opening wide; or, if deep and not opening wide then the anther-cells not divergent or the leaves glossy $\left[40^{*}:\right.$ p. 345$] \quad \ldots \ldots \ldots \ldots \ldots \ldots \ldots \ldots \ldots \ldots \ldots \ldots \ldots . \ldots \ldots$.

41 Leaves not both incurved (in cross-section) and pungent-pointed or if occasionally so then the style tapering and the stigma not proportionately large $\left[41^{*}:\right.$ p. 345] . . . . . . . . . . . . . . . . 42.

42 Leaf-base narrow but not petiolate . . . . . . . . . . 43 .

43 Leaves obtuse, retuse or acute without a stout blunt point . . . . . 44.

44 Fruit-rim and valves not very thick. Sepals with hairs at least at the apex. 
45 Flowering shoots more than 1-, usually more than 2-, flowered. Fruit scarcely woody and with a long, narrow stalk .... 39. L. emarginatum

$45^{*}$ Flowers on the flowering shoot $1(-2)$. Fruit with the stalk short (c. $1 \mathrm{~mm}$ ) or absent .......................... 46 .

46 Fruit (including the stalk) usually rather broad and shallow, with the valves approximately equal in height to the base and the upper surface evenly rounded or raised near the style; later often opening wide $\ldots . . .47$.

47 Fruit with the upper surface evenly rounded and the valves, if concave, only so near the tip. Leaves usually c. 6 times as long as broad

$\ldots \ldots \ldots \ldots \ldots \ldots \ldots \ldots \ldots \ldots \ldots \ldots \ldots \ldots$ 43. L. petersonii

$47^{*}$ Fruit with the upper surface raised near the style, and the valves concave. Leaves no more than 4 times as long as broad . . . . . . . . . . 42.

48 Leaves usually $15-35 \mathrm{~mm}$ long . . . . . . . . 40. L. javanicum

48* Leaves usually 3-6 mm long

41. L. recurvum

$46^{*}$ Fruit (including the stalk) as deep or deeper than broad with the valves high but rounded and shorter than the base; later not opening wider than the $\operatorname{rim} \ldots \ldots \ldots \ldots \ldots \ldots \ldots \ldots \ldots \ldots \ldots \ldots$ 42. L. wooroonooran

$44^{*}$ Fruit-rim and valves very thick and woody. Sepals glabrous

44. L. liversidgei

$43^{*}$ Leaves acute with a short, stout, blunt point

49 Stamens c. $2 \mathrm{~mm}$ long. Style-base not inset in the surface of the fruit-top

51. L. sejunctum

$49^{*}$ Stamens 3-5 mm long. Style-base inset in the fruit-top surface . . . 50.

50 Base of the opened fruit rounded $\ldots \ldots \ldots \ldots$ 47. L. variabile

$50^{*}$ Base of the opened fruit flat

48. L. oreophilum

$42^{*}$ Leaf-base petiolate, at least in the majority of leaves $\ldots \ldots \ldots \ldots 51$.

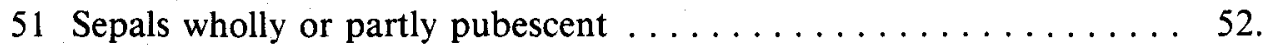

52 Fruit almost globular (before opening). Stem-flange inconspicuous

$\ldots \ldots \ldots \ldots \ldots \ldots \ldots \ldots \ldots$ 53. L. myrtifolium

$52 *$ Fruit broader than deep. Stem-flange conspicuous $\ldots \ldots \ldots \ldots \ldots .$.

53 Hypanthium not conspicuously flared in the upper part. Leaves obovate to oblanceolate

54. L. gregarium

$53^{*}$ Hypanthium conspicuously flared in the upper part. Leaves very broadly obovate-elliptical

56. L. argenteum

$51^{*}$ Sepals glabrous, or rarely silky or minutely ciliate $\ldots \ldots \ldots \ldots \ldots$.

54 Seeds mostly $1.5-2.5 \mathrm{~mm}$ long. Fruit small or large $\ldots \ldots \ldots \ldots .$.

55 Leaves usually more than $7 \mathrm{~mm}$ in length or if sometimes less than $7 \mathrm{~mm}$ then either the leaves not thick and glossy, or the leaves elliptical, or the flowers more than $1 \mathrm{~cm}$ wide $\ldots \ldots \ldots \ldots \ldots \ldots \ldots \ldots \ldots \ldots . \ldots \ldots$

56 Branching at an angle of c. $30^{\circ}$. Leaves variable but usually narrowly oblanceolate to obovate. Bark close and firm . . . . . 55. L. obovatum

$56^{*}$ Branching at $45^{\circ}-60^{\circ}$. Leaves various. Bark (as seen on specimens) flaking ......................... 57 
57 Leaf-apex usually broadly rounded, rarely broadly acute with a short blunt point

57. L. micromyrtus

$57^{*}$ Leaf-apex acute or acuminate and usually pungent-pointed

49. L. novae-angliae

$55^{*}$ Leaves usually no more than $7 \mathrm{~mm}$ in length, obovate, thick and glossy. Flowers usually up to $1 \mathrm{~cm}$ in width $\ldots \ldots \ldots \ldots \ldots \ldots . \ldots 58$.

58 Stamens longer than the petals 50. L. minutifolium

58* Stamens much shorter than the petals 52. L. rupestre $54^{*}$ Seeds at least $3 \mathrm{~mm}$ in length. Fruit large (at least $8 \mathrm{~mm}$ in diameter) 59.

59 Leaves mostly more than $10 \mathrm{~mm}$ long; the bases tapering

64. L. grandiflorum

59* Leaves usually 4-7 mm long; almost orbicular above a narrow petiole

63. L. rotundifolium

$41^{*}$ Leaves incurved (in cross-section) and pungent-pointed. Style stout and straight with a characteristic flat and proportionately large stigma $\ldots 60$.

60 Leaves usually spreading $\ldots \ldots \ldots \ldots \ldots \ldots \ldots \ldots \ldots \ldots \ldots \ldots \ldots \ldots \ldots .$.

61 Flowers produced on new growth $\ldots \ldots \ldots \ldots \ldots \ldots \ldots \ldots \ldots \ldots \ldots .$.

62 Most leaves more than $3 \mathrm{~mm}$, often more than $5 \mathrm{~mm}$, in width and almost flat or somewhat incurved from the margin; broadest below the centre and tapering below and above. Fruit occasionally c. $6 \mathrm{~mm}$ but often $8 \mathrm{~mm}$ or more in diameter

58. L. scoparium

$62^{*}$ Most leaves (3-) $2 \mathrm{~mm}$ or less in width and strongly incurved from the margin; tapering gradually upward from near the base and with the broadest part very close to the base. Fruit $5-6(-7) \mathrm{mm}$ in diameter

59. L. continentale

$61^{*}$ Flowers produced on short shoots arising from older branches

62. L. squarrosum

60* Leaves erect and rather dense, giving the plant a "Broom"-like appearance

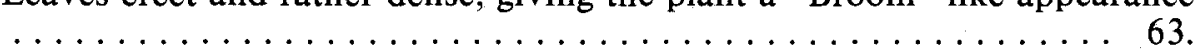

63 Short and robust shrubs with flowers $10 \mathrm{~mm}$ or more, and fruit up to $10 \mathrm{~mm}$, in diameter $\ldots \ldots \ldots \ldots \ldots \ldots \ldots \ldots \ldots \ldots$ 61. L. rupicola

63* Tall and slender shrubs with flowers often less than $10 \mathrm{~mm}$, and fruit often much less than $7 \mathrm{~mm}$, in diameter ........ 60 . L. juniperinum

$40^{*}$ Anther-cells deep, not opening wide and usually divergent or separated.

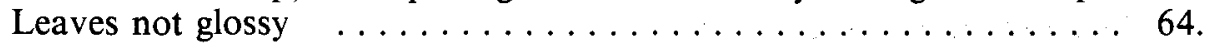

64 Flowers usually about $1.5 \mathrm{~cm}$ in diameter. Leaves usually more than $2 \mathrm{~cm}$ long; broad, often somewhat falcate and usually conspicuously 3-veined and aromatic

46. L. morrisonii

64* Flowers usually c. $1 \mathrm{~cm}$ in diameter. Leaves various but rarely more than 2 $\mathrm{cm}$ long and if falcate then slender; not conspicuously 3-veined or aromatic $\ldots \ldots \ldots \ldots \ldots \ldots \ldots \ldots \ldots \ldots \ldots \ldots \ldots \ldots$ 45. L. polygalifolium

$39^{*}$ Sepals persistent. Leaves never lemon-scented. Stem-flange rarely

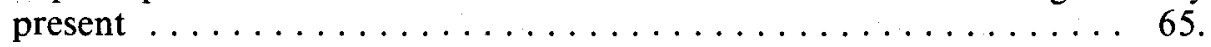


65 Stamens short in proportion to the petal-length. Style-base inset. Seeds no more than $3 \mathrm{~mm}$ in length $\ldots \ldots \ldots \ldots \ldots \ldots \ldots \ldots \ldots \ldots \ldots . \ldots \ldots .$.

66 Fruit-valves (at the time of opening) not conspicuously exserted . . 67.

67 Leaves with a tapering pungent-pointed apex and incurved in cross-section 68. L. arachnoides

$67^{*}$ Leaves blunt or pungent, usually flat or with the margins recurved; if the margins incurved then the apex not pungent $\ldots \ldots \ldots \ldots \ldots 68$.

68 Sepals short with the apex broadly rounded $\ldots \ldots \ldots \ldots \ldots \ldots 69$.

69 Leaves often at least $4 \mathrm{~mm}$ in width and twice as long . 69. L. thompsonii 69* Leaves mostly less than $3 \mathrm{~mm}$ wide and more than twice as long

70. L. glabrescens

$68^{*}$ Sepals very long-deltoid $\ldots \ldots \ldots \ldots \ldots \ldots \ldots \ldots \ldots \ldots \ldots \ldots \ldots \ldots \ldots$.

70 Fruit-base narrow $\ldots \ldots \ldots \ldots \ldots \ldots \ldots \ldots \ldots$ 74. L. riparium

$70^{*}$ Fruit broad-based $\ldots \ldots \ldots \ldots \ldots \ldots \ldots \ldots \ldots \ldots \ldots \ldots \ldots \ldots$ 75. L. nitidum

$66 *$ Fruit-valves conspicuously exserted $\ldots \ldots \ldots \ldots \ldots \ldots \ldots . \ldots \ldots$.

71 Leaves flat or with the margins recurved; the apex usually shortly pungent ................................. 72 .

72 Leaves not glossy on both surfaces; if glossy on the upper surface, the lower usually pubescent or dull $\ldots \ldots \ldots \ldots \ldots \ldots \ldots \ldots \ldots \ldots \ldots \ldots . \ldots$.

73 Fruit with a distinct stalked base; the valve-surface close . 65. L. deuense 73* Fruit sessile; the valve-surface lifting $\ldots \ldots \ldots \ldots \ldots \ldots \ldots \ldots \ldots \ldots$.

74 Leaves broadest near, and abruptly contracting to, the apex; grey-green (rarely green), usually less than $15 \mathrm{~mm}$ long, narrow and usually pubescent on both surfaces. Bark usually close and fibrous and, though shaggy in older plants, probably never exfoliating in firm layers .... 67. L. lanigerum

$74^{*}$ Leaves broadest near the centre or, if broadest above the centre, tapering to the apex; green, either short and broad and very glossy on the upper surface and with a dense pubescence below, or (riparian forms) $2 \mathrm{~cm}$ or more in length with the lower surface glabrous, or with intermediate proportions and pubescence. Bark smooth and exfoliating, with the firm (not fibrous or papery) layers tending to persist on the stems ... 66. L. grandifolium

$72 *$ Leaves glossy on both surfaces $\ldots \ldots \ldots \ldots \ldots \ldots \ldots \ldots \ldots \ldots \ldots \ldots$.

75 Hypanthium with long hairs. Fruit-base ultimately tapering (obconical)

77. L. turbinatum

$75^{*}$ Hypanthium with short hairs. Fruit-base eventually flat . 76. L. petraeum $71^{*}$ Leaves incurved in cross-section; the apex blunt $\ldots \ldots \ldots \ldots .76$.

76 Leaves at least $5 \mathrm{~mm}$ in length; the apex somewhat acute

78. L. crassifolium

76* Leaves $2-3 \mathrm{~mm}$ long, obtuse $\ldots \ldots \ldots \ldots \ldots$ 79. L. epacridoideum

$65^{*}$ Stamens long, all more than $1 / 2$ the length of the petals. Style-base not inset.

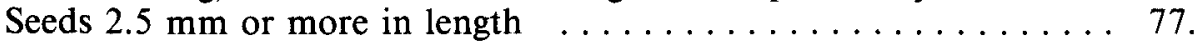

77 Fruit as deep as wide $\ldots \ldots \ldots \ldots \ldots \ldots \ldots \ldots \ldots \ldots \ldots \ldots \ldots \ldots \ldots$. 
78 Leaves less than $2 \mathrm{~cm}$ long. Flowers white or pink . 73. L. sphaerocarpum 78* Leaves more than $2 \mathrm{~cm}$ long. Flowers red ... . . . 71. L. spectabile $77^{*}$ Fruit wider than deep $\ldots \ldots \ldots \ldots \ldots \ldots$ 72. L. macrocarpum

\section{Specific Descriptions - Group 1}

\section{L. brachyandrum subgroup (spp. 1-12), Map 3.}

\section{L. macgillivrayi $J$. Thompson sp. nov.}

Frutex usque ad $1 \mathrm{~m}$ altus. Folia crassa obovata, usque ad $8 \mathrm{~mm}$ longa. Flores sepalis glabratis chartaceis persistentibus. Filamenta pergracilia. Ovarium 3loculare. Fructus 4-5 mm diametro, decidui, valvis glabratis rigidis.

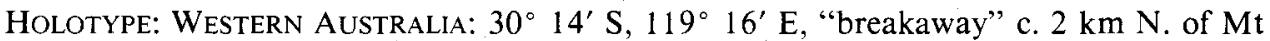
Jackson on road to Die Hardy Range, D.J. McGillivray 3678 \& A.S. George, 4.vii.1976 (NSW).

Open divaricate shrub to $1 \mathrm{~m}$ tall, with firm, gnarled bark; the younger stems short and stout, with seasonal growth very limited, pubescent, terete and without flanges or ridges below the leaves but with conspicuous leaf-scars, the branching at c. $45^{\circ}$. Leaves crowded and divergent, $8 \mathrm{~mm}$ or less in length and up to $5 \mathrm{~mm}$ wide, broadly obovate, thick, incurved or folded near the apex, with a fine appressed pubescence, the apex obtuse or even somewhat emarginate, with a small umbo at the back, the base tapering to a somewhat flattened petiole of $1 \mathrm{~mm}$ or less. Flowers (not seen beyond the young-bud stage) occurring singly on modified shoots at the ends of few-leaved or leafless axillary side-branches, often at the end of a previous season's growth, frequently with 1 or 2 of the subtending leaves modified (with the blade reduced in size). Bracts few, enclosing the very young bud; the bracteoles large, papery and glabrous, the outer enclosing the inner and all tending to lift together as an almost spherical unit. Hypanthium densely covered with long white shining hairs that are loosely appressed to spreading and often curved so that the pile lies in one direction, c. $3 \mathrm{~mm}$ long, tapering to the base, with the upper part incurved and the top of the ovary probably glabrous. Sepals in the bud imbricate and almost spherical; as seen on the fruit, persistent, $1.5 \mathrm{~mm}$ long, very pale, glabrous and papery, ovate-deltoid and obtuse. Petals not seen mature. Stamens in bundles probably of $5-7$, the filaments extremely slender, c. $3 \mathrm{~mm}$ long, the anther-cells $<0.5 \mathrm{~mm}$ long, parallel longer than broad and shallow. Style (in fruit) long and slender, somewhat broader at the base, inset, and on a distinct stout base, the stigma, relative to the style, small and somewhat lobed. Ovary (2-)3-locular, each loculus with c. 20 ovules in c. 6 rows on a broad placenta with a rounded surface. Fruit deciduous, c. $4-5 \mathrm{~mm}$ in diameter, the base broadly conical and densely pubescent, the valves glabrous, rigid and smooth and at first only rounded above the incurved, appressed upper part of the hypanthium but later exserted to approximately equal the base. Mature seeds c. $1.5 \mathrm{~mm}$ long, obovoid to broadly cuneiform with a long-reticulate pattern. Main flowering period: probably Aug.-Sept. 
DISTRIBUTION: Known only from the Type and the other specimen cited. From separate locations in the northeast portion of the Coolgardie District of Western Australia (Map 3). In tall open shrubland on reddish loam from decaying granite.

Other Specimen Examined: Western Australia: Coolgardie: $33 \mathrm{~km} \mathrm{~S}$. of Die Hardy Range gap, George 14319, 7.1976 (PERTH).

This species is named after D.J. McGillivray, Botanist of the National Herbarium of New South Wales who collected and photographed the first specimen. It is very distinct from all other species of Leptospermum and can be readily identified by the sepals. It shares several characters with the equally anomalous $L$. spinescens. The orthography of this specific name follows Rec. 73c.4.(a) of the International Code of Botanical Nomenclature (1983), and is deliberate.

\section{L. spinescens Endl. in Endl. et al., Enum. Pl.: 50 (1837).}

HolotyPe: Western Australia: King Georges Sound, Huegel (W, n.v.).

Spinescent shrub usually less than $1.5 \mathrm{~m}$ tall, with rather corrugated firm but soft (corky) bark; the younger stems stout and tapering, glabrous or pubescent, terete and without flanges or ridges but with conspicuous leaf-scars, and with branching at $60^{\circ}$ or even $90^{\circ}$. Leaves divergent, and sometimes somewhat recurved near the apex, variable in size, usually 5-15 $\mathrm{mm}$ long and 2-5 $\mathrm{mm}$ wide, obovate-elliptical, thick, usually glabrous at maturity, with the margins often tuberculate, flat to somewhat incurved or folded, the apex broadly rounded to acute, often with a short, blunt point, the base tapered to a short petiole. Flowers white or greenish cream, 10-15 $\mathrm{mm}$ in diameter with the fertile ones soon enlarging, occurring singly, each subtended by a bract, in leaf-axils or (on old wood) leaf-scars, or in axils subtended by a series of bracts, or in leaf-axils subtended only by bracteoles. Bracts small, often single; the bracteoles large, orbicular, concave, red-brown and scarious, and shed before or after the flower opens. Hypanthium with a dense silky pubescence, c. 5-8 $\mathrm{mm}$ long, and tapering to the base or rounded, the upper part tending to curve inward, the top of the ovary dark and glabrous. Sepals persistent, c. $2 \mathrm{~mm}$ long, hemispherical, silky pubescent with pale thin margins. Petals 3-6 mm long. Stamens in bundles of 3-7, the filaments very broad in the lower part and irregular, 2.5-4 mm long, the anther-cells c. $0.5 \mathrm{~mm}$ long, parallel, broad and shallow. Style scarcely inset, stout and broad-based, the stigma, relative to the style, large; often absent. Ovary 3-5-locular, each loculus with c. 80 ovules in c. 6 rows on a placenta with a rather flat surface; often absent. Fruit long-persistent, ultimately very gnarled and sometimes almost engulfed by stem-growth, variable in size but often more than $20 \mathrm{~mm}$ in diameter, widest at the base of the free part of the hypanthium with the persistent sepals and top of the hypanthium folded inward, the lower part shallow and broad-based, the valves very thick and woody, and at first smooth and somewhat raised, i.e. to about $1 / 3$ the depth of the fruit. Mature seeds $3.5-4 \mathrm{~mm}$ long, broadly cuneiform to irregularly oblong and of variable width, the outer surface of loose fibres and, before splitting, so narrowly reticulate as to appear striate. Main flowering period: Sept.-Nov.

DiSTRIBUTION: In southwestern Western Australia (Map 3). On sandy and lateritic soils.

Selected Specimens: Western Australia: Irwin: 4 miles $[6.4 \mathrm{~km}] \mathrm{W}$. of Strawberry, Briggs NSW 154710, 10.1960 (NSW); c. $50 \mathrm{~km} \mathrm{N.} \mathrm{of} \mathrm{Gingin,} \mathrm{Thompson} \mathrm{4535,} 9.1987$ (NSW, PERTH). Darling: 9 miles [14.5 km] W. of Yanchep, Phillips 013236, 9.1962 (CBG, NSW); Cottesloe, Fitzgerald NSW 154709, 11.1900 (NSW). Avon: Tammin, 

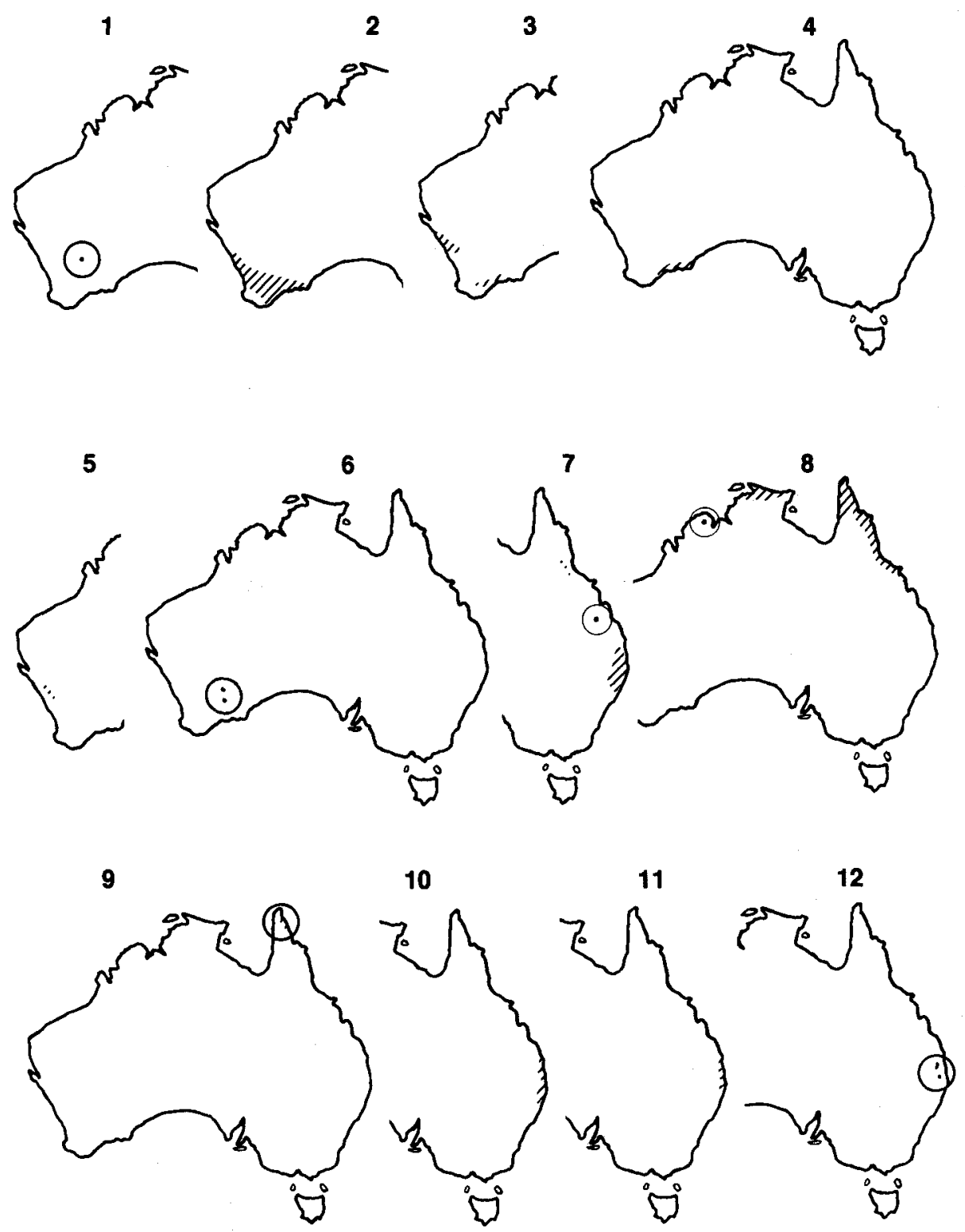

Map 3. Distribution of Group 1: subgroup 1 L. brachyandrum and allies. 1. $L$. macgillivrayi 2. L. spinescens 3. L. oligandrum 4. L. maxwelli 5. L. exsertum 6. $L$. subtenue 7. L. brachyandrum 8. L. parviflorum 9. L. purpurascens 10. L. whitei 11. $L$. speciosum 12. L. luehmannii. 
Gardner 612, 11.1920 (PERTH). Roe: Bendering, Gardner s.n., 9.1923 (PERTH); 100 $\mathrm{km} \mathrm{N}$. of Ravensthorpe, Cranfield 997B, 11.1978 (PERTH); Kukerin, Cough 48, 10.1962 (PERTH). Eyre: South Stirling, Royce 6081, 10.1959 (PERTH); $3 \mathrm{~km} \mathrm{W.} \mathrm{of}$ Israelite Bay ruins, Crisp 4888, 1.1979 (CBG, PERTH).

3. L. oligandrum Turcz., Bull. Cl. Phys.-Math. Acad. Imp. Sci. SaintPétersbourg 10: 335 (1852).

Holotype: Western Australia: Drum/mond] [Coll.] V, n. 129 (?KW, n.v.). Isotypes: MEL, NSW.

SyNONYMY: Kunzea podantha F. Muell., Fragm. 2: 28 (1860). L. erubescens var psilocalyx Benth., F1 Austral. 3: 109 (1867). L. podanthum (F. Muell.) Diels in Diels \& Pritzel, Bot. Jahrb. Syst. 35: 423 (1904). LECTOTYPE: here chosen: WESTERN AuSTRALIA: Phillips Flat, [Maxwell] (MEL 615686). The original citation 'ad ripas amnium Phillips et Fitzgerald River. Mx [Maxwell] is a composite locality and does not identify a particular specimen.

Leptospermopsis myrtifolia S. Moore, J. Linn. Soc. Bot. 45: 202 (1920). HolotYPE: WESTERn AUSTRALIA: Fitzgerald River, Maxwell (BM, n.v.).

Erect spreading shrub from less than 1 to more than $3 \mathrm{~m}$ tall with (as seen on specimens) stringy and rather flaky but close bark; the younger stems silkypubescent but usually glabrescent, without a flange but swollen below each node and branching usually at $30^{\circ}-45^{\circ}$ and somewhat flexuose, the branch-diameter enlarging rapidly with the order of branching. Leaves usually diverging, 3-10 $\mathrm{mm}$ long and $2-4 \mathrm{~mm}$ wide, somewhat silky to glabrous, broadly obovate to cuneate, with the apex acute to truncate or even retuse, often infolded and with or without a very short recurved point, and tapering at the base, often into a short, $<1 \mathrm{~mm}$, rounded petiole. Flowers white, $6-10 \mathrm{~mm}$ in diameter, $1-3$ in bract-axils at the ends of adjacent, short, leafy, leaf-subtended side-branches, often at the ends of limited development of the previous seasons branchlets, occasionally as leafless axillary shoots or even as axillary monads, and often as monads at the base of precocious new leafy growth. Bracts and bracteoles red-brown, broadly obovate, rather thickened at the base, all shed very early and leaving raised scars on the stem. Hypanthium delicate, glabrous, and often with conspicuous vertical ridges, or partly or wholly silky-pubescent, to 2-3 mm or more in length, the upper part scarcely expanded, the part about the ovary only $2-3 \mathrm{~mm}$ long and rather abruptly narrowing to a tapering, very slender, pedicel usually 2-5 mm long, the top of the ovary with a dense silky pubescence. Sepals persistent, c. 1-1.5 mm long, glabrous to densely silkypubescent, usually, but not invariably, with densely pubescent margins, deltoid with the apex somewhat hooded, undifferentiated from the hypanthium and often with a central rib. Petals 1.5-c. $3 \mathrm{~mm}$ long. Stamens 1-3 per bundle, 0.75-1.25 mm long, the filaments broad in the lower part, the anther-cells c. 0.3 $\mathrm{mm}$ long, parallel, broad and shallow. Style well inset, rather stout with a large (relative to the style) stigma. Ovary 5-locular, each loculus with c. 20 ovules in 4 rows on a large, sometimes somewhat narrowed (wedge-like) placenta. Fruit deciduous, 2-4 $\mathrm{mm}$ in diameter, the upper part not expanded, even somewhat contracted, and not forming a conspicuous rim but bearing the persistent sepals, the lower often distinctly lobed in cross-section, with an almost inset narrow stalk several $\mathrm{mm}$ long, the valves not woody, exserted above the hypanthium-top especially near the style-base and later to c. $1 / 2$ the depth of the broad part of the fruit. Mature seeds c. $1 \mathrm{~mm}$ long, obovoid, with a very 
shallow reticulate pattern. Main flowering period: Sept.-Dec.

DistriBUTION: Disjunct, being widespread in the Irwin District and on adjoining parts of the northern Avon and Darling Districts; and in the southern Darling and Irwin Districts of Western Australia (Map 3). Usually in heath or scrub on sandy soils or laterite.

Selected Specimens: Western Australia: Irwin: 10 miles [16 km] S. of Coorow on Geraldton Highway, Melville 4119 \& Calaby, 7.1953 (MEL, NSW); 2 km NW. of Mt Lesueur, NE. of Jurien, Griffin 2669, 12.1979 (PERTH). Avon: Reynold's Flora Reserve, Wongan Hills, Beard 5131, 10.1967 (PERTH). Darling: Mt Barker, Oldfield (MEL). Eyre: Phillips flat, [Maxwell] (MEL); Oldfield R. at crossing of the EsperanceRavensthorpe road, Orchard 1507, 10.1968 (AD, PERTH), Thompson 4636, 10.1987 (NSW, PERTH). Without precise locality: S.W. Australia, Maxwell, (MEL).

\section{L. maxwellii S. Moore, J. Linn. Soc. Bot. 45: 201 (1920).}

Holotype: Western Australia: Fitzgerald R., Western Australia, Maxwell 202 (BM, n.v.). ISOTYPE: NSW.

Shrub, low-growing and spreading or open and erect and to $2 \mathrm{~m}$ tall, with (as seen on specimens) bark tending to have thin flaking layers; the younger stems silky-pubescent, glabrescent; and without a flange but swollen below each node and usually branching at $30^{\circ}-45^{\circ}$. Leaves usually somewhat divergent, from a few to c. $12 \mathrm{~mm}$ long and $1-5 \mathrm{~mm}$ wide, obovate, occasionally narrowly so, mostly glabrous but often with some hairs especially on the margins, the apex broadly rounded with the centre tending to recurve, the base long-tapering to a short petiole. Flowers white, c. $8 \mathrm{~mm}$, occasionally c. $12 \mathrm{~mm}$, in diameter, usually 2 , sometimes 1 , rarely 3 , in bract-axils at the ends of adjacent leafless or short leafy side-branches often at the end of limited development of the previous season's growth, the terminal growth sometimes precocious leaving flowers as axillary monads at the base. Bracts and bracteoles red-brown, shed from the very young bud leaving prominent scars on the stem. Hypanthium usually marked with vertical ridges and at least for the most part glabrous although often with the base silky, usually with the part about the ovary in a largeflowered form c. $3 \mathrm{~mm}$ but in the more widespread smaller form c. $2 \mathrm{~mm}$, above this spreading, and below tapering gradually to a slender pedicel, the top of the ovary with a dense rather erect pubescence. Sepals persistent, 1-2 mm long, indistinguishable in texture from the hypanthium, deltoid to long-deltoid, somewhat keeled and hooded, usually pubescent at least on the margins and at the apex, and tending to arch over the top of the ovary. Petals $2.5-5 \mathrm{~mm}$ long. Stamens in bundles of $1-5$, the filaments broad in the lower part, the anthercells c. $0.3 \mathrm{~mm}(-0.5 \mathrm{~mm}$ in the large-flowered form) long, parallel, broad and shallow. Style deeply inset, slightly tapered, the stigma small. Ovary 5-locular, each loculus with the few ovules (varying within the flowers but usually 4-12) pendulous, or mostly so, in 2 rows on a narrow (wedge-shaped) placenta high in the loculus. Fruit deciduous, to $5 \mathrm{~mm}$ in diameter (on the only specimen seen), the outer surface rather glossy and wrinkled, the upper part of the hypanthium not forming a conspicuous rim, but erect with spreading incurved sepals, the lower part somewhat shorter than broad, lobed in cross-section and rounded or tapering above a stout but tapering stalk, the valves not woody, exserted above the hypanthium-top especially near the style-base, eventually to c. $1 \mathrm{~mm}$. Mature seeds $1.5 \mathrm{~mm}$ long, obovoid-cuneiform, with a very coarsely reticulate surface. Main flowering period; Sept.-Nov. 
DISTRIBUTION: Widespread in the Eyre District and occasionally reaching the southern part of the Roe District of Western Australia (Map 3). In sandy soil or on coastal dunes.

Selected Specimens: Western Australia: Roe: Scadden [as Scanden], Cranfield 1065, 11.1978 (PERTH). Eyre: FitzgeraldRange, (MEL); Esperance-Ravensthorpe, Edmiston E. 562, 11.1973 (PERTH); c. $14 \mathrm{~km}$ E. of the mouth of the Oldfield R., Eichler 20201, 10.1968 (AD, PERTH); Merivale, Thompson 4632, 10.1987 (NSW, PERTH); Pt Malcolm, Gardner \& Blackall 1196, 10.1931 (PERTH). Without precise locality: S.W. Australia, Maxwell (MEL).

\section{L. exsertum $J$. Thompson sp. nov.}

Frutex minus quam $1 \mathrm{~m}$ altus. Folia crassa obcordata ad obcuneata, 3-5 mm longa. Flores 5-8 $\mathrm{mm}$ diametro, sepalis glabratis persistentibus. Ovarium 3loculare. Fructus c. $3 \mathrm{~mm}$ diametro decidui, valvis glabratis supra basin brevem valde exsertis.

Holotype: Western Australia: Gerber's Farm, E. of Tardun, J.S. Beard 6697, 27 Sept. 1973 (NSW). IsOTYPE: Perth.

Sparsely branched shrub less than $1 \mathrm{~m}$ tall, with (as seen from specimens) close firm bark; the younger stems glabrous and rather glossy, without a flange but with a swelling below each node that leaves a prominent scar on older stems, and with the branching at an angle of $45^{\circ}-60^{\circ}$. Leaves at first erect and well-spaced, later spreading, mostly c. $3-5 \mathrm{~mm}$ long and 2-3 mm wide, broadly obcuneate to obcordate, very thick in texture and concave, sometimes somewhat glaucous or puberulous, very broadly rounded to almost emarginate at the apex, the tip recurved and often pungent-pointed, tapering at the base to a petiole. Flowers white, $5-8 \mathrm{~mm}$ in diameter, occurring singly or 2(-3) together, each in a bract-axil, at the ends of long or short leafy side-branches. Bracts usually red-brown and scarious, often leaf- or leaf-base-like, small, thick and tending to persist; the bracteoles thin, large, red-brown and concave, and shed from the bud. Hypanthium usually with a dense irregularly spreading pubescence on the wrinkled tapering part about the ovary and short pedicel, c. $2 \mathrm{~mm}$ deep, the upper part much expanded, erect, dark and glabrous, the top of the ovary elevated and glabrous. Sepals persistent, 1.5-2 $\mathrm{mm}$ long, deltoid, acute, somewhat keeled, glabrous, dark and scarcely differentiated from the hypanthium. Petals c. $3 \mathrm{~mm}$ long. Stamens in bundles of c. 5, c. $1.5 \mathrm{~mm}$ long, the filaments slender, the anther-cells c. $0.3 \mathrm{~mm}$ long, parallel, broad and shallow. Style inset, slender but tapering towards the small stigma. Ovary 3-locular, each loculus extended upward, with c. 5 pendulous ovules in 2 rows on a narrow-based, pendulous, very high placenta, the upper ovules appearing to be aborted. Fruit (not seen mature) deciduous, c. $3 \mathrm{~mm}$ in diameter, the upper part glabrous and forming a wide rim, the lower part pubescent, very short, and rather rounded above a short pubescent stalk, the valves glabrous and exserted high above the erect hypanthium-rim, almost reaching the level of the long erect sepal-tips. Seeds not seen mature, c. $1.5 \mathrm{~mm}$ long, probably rather oblong with an obviously patterned long-reticulate surface. Main flowering period: Aug.-Sept.

DISTRIBUTION: In the northwestern corner of the Avon District of Western Australia (Map 3). In sandy heath or on sandplain.

Selected SPecimens: WeStern Australia: Avon: Mullewa, Galbraith 411, 8.1964 (MEL, PERTH); Perenjori, Gardner 2685, 9.1931 (PERTH). 
The species is named for its long-exserted fruit-valves.

\section{L. subtenue $J$. Thompson sp. nov.}

Frutex c. $1 \mathrm{~m}$ altus. Folia crassa anguste elliptica ad oblanceolata, $1-1.5 \mathrm{~cm}$ longa. Flores 8-10 $\mathrm{mm}$ diametro, ad apicem ramulorum tenuium dispersarum, sepalis pubescentibus vel glabratis persistentibus. Ovarium 3-loculare. Fructus decidui.

Holotype: Western Australia: N. of Esperance, C. Andrews, Oct. 1903 (W.E. Blackall Collection, PERTH). IsOTYPE: herb. C.A. Gardner 1267 (PERTH).

Shrub c. $1 \mathrm{~m}$ tall, the bark (as seen on specimens) close; the young stems very slender, at first silky-pubescent but soon becoming glabrous, without a flange but with a cup-shaped extension below each node that remains on older branches, and with the branching at an angle of c. $45^{\circ}$. Leaves rather wellspaced and erect, 3-4 mm long, and 1-1.5 mm wide, elliptical, thick, especially near the obtuse apex, concave, glabrous or silky-pubescent and tapering gradually to a slender petiole. Flowers white or pink, to $12 \mathrm{~mm}$ in diameter, occurring singly, occasionally 2 together, each in a bract-axil, at the ends of long and slender side-branches that are scattered (rather than in adjacent leaf-axils), but with most branchlets terminated by flowering shoots, and with new growth appearing to develop where flowers have been aborted rather than shed. Bracts scarious, pale red-brown, short and broad; the bracteoles red-brown, scarious, very large, broad and concave, all shed from the young bud leaving conspicuous scars. Hypanthium densely and shaggily pubescent, all over or at least on the lower part, dark-coloured and ridged, c. $3 \mathrm{~mm}$ long and tapering to a more or less pedicel-like base, the upper part expanded and erect, occasionally glabrous, the top of the ovary pubescent near the style but otherwise almost glabrous. Sepals persistent, c. $2 \mathrm{~mm}$ long, broadly ovate, densely pubescent to glabrous, rather keeled and hooded, and like the hypanthium in texture apart from the thin scarious margins. Petals c. $4 \mathrm{~mm}$ long. Stamens in bundles of 5-7, c. $1 \mathrm{~mm}$ long, the anther-cells c. $0.3 \mathrm{~mm}$ long, parallel, broad and shallow. Style rather shallowly inset, very broad-based, tapering to a slender upper part, with a small stigma. Ovary 3-locular, each loculus extended upward with c. 6-12 ovules in 2 rows on a small narrow and high placenta. Fruit (not seen mature) deciduous, the valves thin and raised high above the erect upper part of the hypanthium. Mature seeds not seen; immature c. $1.5 \mathrm{~mm}$ long and narrow-oblong with little surface marking. Main flowering period: Sept.-Oct.

DISTRIBUTION: In inland southwestern Australia south of Kalgoorlie (Map 3). In deep lateritic gravel.

SPECIMENS EXAMINED: WeSTern AuSTRALia: Coolgardie: $21 \mathrm{~km}$ SE. of Londonderry, Wilson 3153, 9.1964 (AD, NSW); 2 miles [3.2 km] N. of Daniell, Newbey 2571, 9.1966 (PERTH); $5 \mathrm{~km} \mathrm{~S}$. of rail crossing near Daniell, Thompson 4626, 10.1987 (NSW, PERTH).

The species is named for the slender branchlets subtending the flowering shoots.

7. L. brachyandrum (F. Muell.) Druce, Bot. Soc. Exch. Club British Isles 1916 Suppl. 2: 632 (1917); Cheel, J. \& Proc. Roy. Soc. New South Wales 65: 199 (1932).

BASIONYM: Kunzea brachyandra F. Muell., Fragm. 2: 27 (1860). 
Lectotype, here chosen: New South Wales: ad ripas fluminis Hastings, Dr. Herman Beckler (NSW 154711). ISOLECTOTYPES: NSW 154712, MEL 1539306.

SYNONYMY: Leptospermum abnorme F. Muell. ex Benth., Fl. Austral. 3: 109 (1867), nom. illegit. Agonis abnormis (F. Muell. ex Benth.) C.T. White \& Francis, Bot. Bull. Dept. Agric. Queensland 22: 20 (1920). TYPE: as for K. brachyandra.

Shrub or small tree to c. $6 \mathrm{~m}$ tall, with bark seasonally exfoliating in strips to expose a smooth shining and often coloured surface below; the younger stems very slender, pubescent, becoming glabrous, with a distinct flange below each node, and branching at c. $30^{\circ}$. Leaves diverging, $20-50 \mathrm{~mm}$ long and usually 2-4 mm wide, linear-lanceolate, usually (when dry) slightly incurved in crosssection, with the upper surface often darker, the lower often retaining a pubescence longer, both usually ultimately glabrous, the apex acute or acuminate, infolded and usually with a short pungent point, the base somewhat tapering with the midvein thickened but the petiole negligible. Flowers white, c. $7 \mathrm{~mm}$ in diameter, occurring several (up to 7) together on condensed shoots, the shoots terminal and in upper axils, with their terminal buds developing strongly after the flowering period. Bracts (several below the lowest flowers) soon deciduous, those subtending flowers more persistent; the bracteoles narrow, keeled and pubescent, all shed before the flower opens. Hypanthium glabrous or with some silky hairs at the base, c. $3 \mathrm{~mm}$ long, the upper part much expanded, the lower gradually contracted to a pedicel, the top of the ovary glabrous. Sepals persistent, c. $1 \mathrm{~mm}$ long, deltoid to almost hemispherical, usually glabrous for the most part, and scarious towards the usually densely ciliate margins. Petals 2-3 $\mathrm{mm}$ long. Stamens in bundles of 3-5 (-7), 1-1.3 mm long, the anther-cells $<0.5 \mathrm{~mm}$ long, parallel, broad and shallow. Style inset, rather stout and straight, the stigma, relative to the style, large. Ovary 3-locular, each loculus with $40-50$ ovules in c. 6 rows on a broad and large placenta. Fruit deciduous, to c. $4 \mathrm{~mm}$ in diameter, glabrous, with the upper part of the hypanthium and sepals erect or folded inward, the lower part almost hemispherical above a short stalk, the valves not woody and not exserted before opening, later raised to slightly above the hypanthium-top. Mature seeds $\mathrm{c} .1 \mathrm{~mm}$ long, irregularly broadly cuneiform, the surface reticulate but rarely broadly so. Main flowering period: Nov.-Jan.

Distribution: Discontinuous, from northeastern New South Wales to north Queensland (Map 3). Among rocks on creek-banks or in stream-beds, especially on sandstone and granite.

Selected SPecimens: QueEnSland: North Kennedy: Mt Spec, Donohue 00008, 5.1972 (BRI). Leichhardt: Rainbow Creek, Blackdown Tableland, Johnson \& Blaxell 744, 9.1972 (NSW). Wide Bay: Burrum R. near the town of Howard, White 6280, 10.1929 (BRI, NSW). Darling Downs: Jolly's Falls, Coveny 9959 \& Haegi, 12.1977 (NSW); between Bald Mtn \& Wyberba, Blake 4505, 1.1933 (BRI, NSW). Moreton: Blunder Creek, White 7197, 10.1930 (BRI, NSW). New South Wales: North Coast: 7 miles [11.3 km] SSE. of Coaldale, Thurtell \& Coveny 3870, 12.1971 (NSW). Northern Tablelands: Severn R, Stuart NSW 154713 (NSW). Northwestern Slopes: Middle Creek, 5 km SE. of Inverell, Millard NSW 154714, 5.1983 (NSW).

8. L. parviflorum Valeton, Bull. Dép. Agric. Indes Néerl. 10: 39 (1907); Icon. Bogor 3: 93, t. 238 (1907).

TYPE: NEW GuINEA: Nova-guinea septentrionalis in monte Syap, ubi legit collector indigenus (iter Wichmannianum 1903) (n.v., identification based on above illustration).

SYNonymy: Agonis longifolia C.T. White \& Francis, Bot. Bull. Dept. Agric. Queensland 22: 18 (1920); Steenis, Rheophytes of the World: 325 (1981). Leptospermum longifolium 
(C.T. White \& Francis) S.T. Blake, Proc. Roy. Soc. Queensland 69: 81 (1958). HOLOTYPE: QUEENSLAND: Endeavour R., (BRI, n.v.).? ISOTYPE: NSW.

Multistemmed shrub or small tree to more than $6 \mathrm{~m}$ tall, with bark seasonally exfoliating in strips to expose a smooth shining and often purplish red surface below; the younger stems very slender, pendulous, glabrescent or with a long fine pubescence, without a distinct flange below each node, and with branching at c. $30^{\circ}$. Leaves diverging, $2-7 \mathrm{~cm}$ long and 2-10 (or more) $\mathrm{mm}$ wide, linearlanceolate, glabrescent, rather thin, the lower surface paler and the margins tending to recurve, the apex usually broadly or narrowly acute with a slender infolded tip often bearing a tuft of hairs, the base tapering, often twisted, with the midrib thickened and without a petiole. Flowers white or cream, 2-7 $\mathrm{mm}$ in diameter, usually occurring several (up to 6) together, each subtended by a bract, at the ends of branches, often in groups of such shoots, and in upper leaf-axils, the terminal buds developing after flowering. Bracts all subtending flowers, soon deciduous; the bracteoles broadly or narrowly lanceolate or oblong, and keeled, shed before the flower opens. Hypanthium glabrous or with a short pubescence, 2-3 $\mathrm{mm}$ long, the upper part much expanded, the lower contracted to a pedicel, the top of the ovary mostly glabrous but with a dense pubescence on the valve-margins. Sepals persistent, $1 \mathrm{~mm}$ or less in length, oblong or hemispherical, the margins and apex scarious and usually densely ciliate. Petals 1-2.5 mm long. Stamens in bundles of $5(-7)$, to $1.25 \mathrm{~mm}$ long, the anther-cells $<0.5 \mathrm{~mm}$ long, parallel, broad and shallow. Style inset, relatively stout and straight, the stigma, relative to the style, large. Ovary 3-locular, each loculus with 50-60 ovules in c. 6 rows on a rather large and broad placenta. Fruit deciduous, c. $4 \mathrm{~mm}$ in diameter, glabrous or pubescent, with the upper part of the hypanthium and sepals erect or infolded, the lower part almost hemispherical above a short stalk, the valves not woody and not exserted beyond the hypanthium-top. Mature seeds c. $1 \mathrm{~mm}$ long, irregularly obovoid-cuneiform, the surface narrowly reticulate. Main flowering period: July-Sept.

Distribution: In New Guinea, the Kimberley region of Western Australia, northern Northern Territory and north Queensland (Map 3). On stream banks and on deep river sands.

SELECTED SPECIMENS: IRIAN JAYA: Subdistrict Merauke: between Boepel and Tanas, Leefers BW 3224, 8.1956 (L). NORTHERN TERrITORY: Finnis R., Byrnes 1684, 8.1969 (NSW). QueEnSLAND: Cook: Lankelly Creek, Coen, Flecker, F.A. Rodway 13239, 7.1949 (NSW); $34.3 \mathrm{~km} \mathrm{NW}$. of Laura P.O. towards 'Musgrave' Stn, Coveny 7036 \& Hind, 9.1975 (NSW); Nutwood Crossing of the Edward R., $15 \mathrm{~km} \mathrm{NNE.} \mathrm{of} \mathrm{Edward} \mathrm{R.}$ Reserve, Clarkson 3512, 10.1980 (BRI, NSW). Western Australia: Kimberley: Piccaninny Creek Gorge, $15 \mathrm{~km}$ SE. of Bungle Bungle Outcamp, E. Kimberley, Kenneally 9301, 7.1984 (PERTH, NSW).

\section{L. purpurascens $J$. Thompson sp. nov.}

Frutex vel arbor usque ad $6 \mathrm{~m}$ alta, cortice laevi purpurascenti. Folia elliptica ad late lanceolata, c. $1 \mathrm{~cm}$ longa. Flores $3-5 \mathrm{~mm}$ diametro, sepalis plus minusve pubescentibus persistentibus. Ovarium 3-loculare. Fructus c. $3 \mathrm{~mm}$ diametro

HolotyPe: QueENSLAND: $12^{\circ} 24^{\prime} \mathrm{S}, 143^{\circ} 07^{\prime} \mathrm{E}$, southern end of Temple Bay in upper reaches of an unnamed creek between Glennie and Hunter inlets, J.R. Clarkson 2196, 08 Jun 1978 (NSW). ISOTYPE: BRI. 
Shrub or small tree to $6 \mathrm{~m}$ tall, with bark seasonally exfoliating in strips to expose a smooth shining purple surface below; the younger stems slender, at first with a short appressed pubescence but ultimately glabrous, with a conspicuous flange extended near the node, and branching at $30^{\circ}-45^{\circ}$. Leaves diverging, c. $1 \mathrm{~cm}$ long and $2-4 \mathrm{~mm}$ wide, elliptical to broad-lanceolate, the surfaces dissimilar, the upper firm, glossy and glabrous, the lower densely silky-pubescent and often almost hidden (in dried specimens) by the strongly recurved or revolute margins, the apex rounded with a small folded recurved tip often bearing a tuft of hairs, the base tapering with the midvein thickened and the petiole negligible. Flowers white, sometimes flushed with red, 3-5 mm in diameter, usually occurring several together, (? aberrantly) with occasional extra flowers, each in a bract-axil, at the ends of branches and on modified shoots in upper axils, with new growth from the terminal bud shortly after or during flowering, often so as to leave flowers as monads at the base. Bracts probably no more than one for each flower; the bracteoles broadly lanceolateoblong and keeled, shed before the flower opens. Hypanthium pubescent with short curved hairs that are longer towards the base, c. $1.5 \mathrm{~mm}$ long; the upper part much expanded, the lower contracted to a pedicel, the top of the ovary usually glabrous beyond a pubescent area near the style-base. Sepals persistent, c. $0.7 \mathrm{~mm}$ long, almost hemispherical, pubescent at least in the centre and on the margins. Petals c. $1.5 \mathrm{~mm}$ long. Stamens in bundles of 3-5, 0.5-1 mm long, the anther-cells $<0.5 \mathrm{~mm}$ long, parallel, broad and shallow. Style inset, rather stout and straight with the stigma, relative to the style, large. Ovary 3-locular, each loculus with up to c. 30 somewhat pendulous ovules in 4-6 rows on a large, broad and rather high placenta. Fruit deciduous, c. $3 \mathrm{~mm}$ in diameter, closely pubescent with the upper part of the hypanthium and sepals infolded, the base rounded above a short stalk, the valves not woody, extending above the erect hypanthium-top. Mature seeds c. $1 \mathrm{~mm}$ long, narrowly obovoid, the surface narrowly reticulate. Main flowering period: June-July.

DisTRIBUTION: In far northern Queensland (Map 3). On rocky hillsides of decomposed granite.

Selected SPECimens: QueEnSLAND: Cook: $3.4 \mathrm{~km}$ by road NNE. of Pascoe R., Coveny $7087 \&$ Hind, 9.1975 (NSW); 5 km NE. of Pascoe R. Crossing, Kennedy Road, Hind 323, 8.1974 (NSW); Kennedy Road, a few miles N. of Pascoe R., Gittins 1019, 8.1965 (NSW).

This species is named for the colour of its bark. A very graphic description, with photographs of both plant and habitat, has been given by Brass (1955).

10. L. whitei Cheel, J. \& Proc. Roy. Soc. New South Wales 65: 199 (1932); S. T. Blake, Proc. Roy. Soc. Queensland 69: 79 (1958).

Basionym: Agonis elliptica C. T. White \& Francis, Bot. Bull. Dept. Agric. Queensland 22: 16 (1920), non Leptospermum ellipticum Endl.

TyPE: QueEnsLand: Beerwah, W. D. Francis (fl. \& fr.) (BRI).

SYNONYMY: A. elliptica var. angustifolia C. T. White \& Francis, op. cit.: 18. SynTYPes: QueEnSLAND: Bribie Island, W. D. Francis, s.d. (BRI); Stradbroke Island, C. T. White, s.d. (BRI).

Shrub to $3 \mathrm{~m}$ or more in height, with bark in many rather fibrous flaking reddish brown layers, or exfoliating; the younger stems pubescent and ridged from the indistinct node-flanges, branching rather densely at c. $30^{\circ}-45^{\circ}$. Leaves 
diverging, up to $25 \mathrm{~mm}$ long and (2-) 3-4 (-7) $\mathrm{mm}$ wide, usually broadly to narrowly elliptical, the surfaces not markedly dissimilar but the lower often paler, glabrescent at maturity except at the base, the margins somewhat incurved, the apex usually tapering and acute with the tip tending to infold, and bluntly pointed, the base tapering with a stout midrib behind but scarcely petiolate. Flowers white, c. $10 \mathrm{~mm}$ in diameter, occurring several together, each in a bract axil, at the ends of branches, or in short dense shoots at the ends of side-branches and in the adjacent upper axils, the terminal buds of the shoots sometimes activated before the end of flowering so that flowers appear as monads at the base. Bracts probably no more than one per flower, broad and imbricate, forming a cone-like structure in the bud; the bracteoles more narrow, pale and pubescent, all usually shed as the flower opens. Hypanthium with a dense short silky pubescence, 2-3 $\mathrm{mm}$ long, the upper part much expanded, the lower tapering to the base, the top of the ovary glabrous except for dense hairs along the valve-margins. Sepals persistent, c. $1.5 \mathrm{~mm}$ long, short-oblong to hemispherical, obtuse, with dense long hairs in the centre and shorter hairs near the more scarious, ciliate margins, rarely the calyx almost glabrous. Petals 3-5 mm long. Stamens in bundles of c. 5 , c. $1.5 \mathrm{~mm}$ long, the filaments very slender, the anther-cells c. $0.25 \mathrm{~mm}$ long, parallel, broad and shallow. Style inset, rather straight and slender with the stigma, relative to the style, large. Ovary 3-locular, each loculus with $20-$ c. 40 ovules in c. 6 rows on a large, broad, rather flat-surfaced placenta. Fruit deciduous, 3-4 $\mathrm{mm}$ in diameter, pubescent, broad at the top with the upper part of the hypanthium and persistent sepals infolded, the base rounded, the valves not woody, not exserted at opening, and ultimately only a little above the hypanthium-top. Mature seeds $\mathrm{c}$. $1.5 \mathrm{~mm}$ long, narrowly obovate-cuneiform, the surface narrowly reticulate. Main flowering period: Oct.-Jan.

Distribution: On the coast from Wide Bay in Queensland to Coffs Harbour in northern New South Wales (Map 3). In sandy, rather swampy, coastal heath.

SEleCted SPECIMENS: QueEnSLAND: Wide Bay: Noosa R., Staer NSW 154715, 9. 1911 (NSW). Moreton: Beerburrum, Francis NSW 154717, 11.1919 (NSW); Stradbroke Island, White NSW 154716, 4.1917 (NSW). NEW SoutH WaLES: North Coast: Tweed R. district, Penfold NSW 154719, 11.1924 (NSW); Byron Bay, Forsyth NSW 154718, 11.1898 (NSW); Evans Head, Coveny 4656, 11.1972 (NSW).

11. L. speciosum Schauer in Walp., Rep., Suppl. 1: 923 (1842); S.T. Blake, Proc. Roy. Soc. Queensland 69: 79 (1958).

Holotype: QueEnSLAND: in Nova Cambria australi, Moreton-Bay, A. Cunn. Herb. no. 38, 1824 (?, dupl. K, fide C.T. White (1942), n.v.).

Synonymy: Agonis speciosa (Schauer) C.T. White, Proc. Roy. Soc. Queensland 53: 218 (1942).

Agonis scortechiniana F. Muell., Fragm. 11: 118 (1881). IsOTYPES: QuEENSLAND: circum paludes insulae Stradbroke-Island, Rev. B. Scortechini (MEL 1539386, 1539387, 1539388).

Shrub usually 1-2 $\mathrm{m}$, but occasionally to $5 \mathrm{~m}$, in height, with pallid bark exfoliating in strips; the younger stems closely pubescent, very stout and indistinctly ridged below the nodes, branching rather sparsely at c. $45^{\circ}$ or more. Leaves erect near the branchlet-ends but spreading or even deflexed later, mostly 20-30 mm long and 5-10 $\mathrm{mm}$ wide, broadly lanceolate to elliptical, long-tapering towards an acute, usually infolded and bluntly pointed apex, firm and flat with the margins tending to incurve, both surfaces pubescent at least at the base, the lower often grey-green, the base abruptly tapering, truncate or 
somewhat auricled above a very short broad, almost negligible, densely pubescent petiole. Flowers white, c. $8-10 \mathrm{~mm}$ in diameter, several, often 3 or more, occurring together each in a bract axil on short dense and densely pubescent shoots at the ends of branches and in the adjacent upper axils, the terminal buds of the shoots forming branched growth after the flowering. Bracts of the flowering shoot probably no more than one per flower, very broad and imbricate, and forming a cone-like structure in the bud; the bracteoles broad and pubescent, tending to be shed, though some persist during flowering. Hypanthium with a dense spreading pubescence, c. $3 \mathrm{~mm}$ long and tapering to a very short pedicel, the upper part spreading, the top of the ovary glabrous with the edges of the valves pubescent, or with a pubescent area near the style-base. Sepals persistent, c. $2 \mathrm{~mm}$ long, ovate-deltoid, with long hairs dense in the centre but fewer near the scarious usually ciliate margins. Petals c. 3-4 $\mathrm{mm}$ long. Stamens in bundles of 5-7, c. $1.5 \mathrm{~mm}$ long, the anther-cells c. $05 \mathrm{~mm}$ long, parallel, broad and shallow. Style inset, rather straight and stout with the style, relative to the stigma, large. Ovary 3-locular, each loculus with c. 40 ovules in c. 6 rows on a large broad, shallow placenta. Fruit deciduous, c. $5 \mathrm{~mm}$ in diameter, pubescent, broad at the top with the upper part of the hypanthium and persistent sepals infolded, the lower part often somewhat lobed in crosssection with the base rounded, the valves not woody, exserted above the hypanthium-top. Mature seeds 1-1.5 mm long, narrowly obovoid-cuneiform, the surface narrowly reticulate. Main flowering period: Aug.-Sept.

Distribution: From Fraser Island, Queensland, to the Clarence R., New South Wales (Map 3). In poor sandy soil of coastal heathy swamps.

Selected SPECIMENS: QueEnSLAND: Wide Bay: Woongoolbver Swamp, Fraser Island, Willis 53/518, 8. 1953 (NSW). Moreton: King John Creek, $1 \frac{112}{2}$ miles $[2.4 \mathrm{~km}] \mathrm{N}$. of Caboolture, Briggs NSW 154720, 5.1961 (NSW). NeW South Wales: North Coast: Wardell, Betche NSW 154721, 8.1884 (NSW); c. $1 \mathrm{~km} \mathrm{~N}$. of Evans Head on the Broadwater road, Coveny 9898 \& Haegi, 12.1977 (NSW).

\section{L. luehmannii Bailey, Queensland Fl. 2: 592 (1900).}

Holotype: QueEnsland: Top of Glass House Mountain, F. M. Bailey 4, Oct. 1884 (BRI).

SYNONYmy: Agonis luehmannii (Bailey) C.T. White \& Francis, Bot. Bull. Dept. Agric. Queensland 22: 21 (1920).

Shrub or small tree to $5 \mathrm{~m}$ tall, with smooth red-brown bark seasonally exfoliating in long strips; the younger stems at first pubescent but later glabrous, with a ridge rather than a flange below each node, and rather slender and dense in spite of their branching at an angle of c. $45^{\circ}$. Leaves rather erect at least at first, usually $1.5-4 \mathrm{~cm}$ long and 6-9 mm wide, elliptical, glossy at maturity and flat or almost so, the apex rounded, rarely with an obscure umbo at the tip and often with a tuft of hairs, the base tapering, usually to a very short petiole, with the base of the midrib much thickened. Flowers white, $6-12 \mathrm{~mm}$ in diameter, occurring several (up to 7) together on condensed shoots that are terminal and in the upper axils, the terminal buds developing after flowering. Bracts broad (with several below the lowest flowers) but soon deciduous; the bracteoles narrow and pubescent, all usually shed before the flower opens. Hypanthium glabrous, 2-3 mm long, with the upper part expanded and the lower tapering to a short pedicel, the top of the ovary glabrous or with hairs along the valvemargins. Sepals rather persistent, 1-1.5 mm long, deltoid obtuse, usually pubescent in the centre but glabrous and pale and scarious towards the usually 
densely ciliate margins. Petals (2-)5-6 mm long. Stamens in bundles of 5-7, 1-2 mm long, the anther-cells c. $0.5 \mathrm{~mm}$ long, parallel, broad, and shallow. Style inset, rather stout and straight with a large stigma. Ovary 3-locular, each loculus with c. 40 ovules in c. 6 rows on a large and broad placenta. Fruit deciduous, 4-5 $\mathrm{mm}$ in diameter, glabrous, with the upper part expanded, and with the free part of the hypanthium and sepals erect or infolded, the lower part tapering gradually, then abruptly to a short stalk, the valves not woody, exserted c. $1 \mathrm{~mm}$ above the hypanthium when opening. Mature seeds c. $1 \mathrm{~mm}$ long, obovoid-cuneiform, with a long-reticulate surface. Main flowering period: Jan.-Feb.

Distribution: On summits and slopes of the Glass House Mountains, and in the Numinbah Valley, of southeastern Queensland (Map 3). In skeletal soils on acid volcanic rocks.

Selected SPecimens: QueEnsland: Moreton: Glass House Mts, NgunNgun, Stauffer 5515 \& Blake, 1.1964 (NSW, PERTH); Mt Ngun Ngun, Melville 3530, 3.1953 (NSW); Mt Tibrogargan, Whaite \& Whate 3069, 1.1966 (NSW); Elimbah ... slopes of Stawee Mtn, Blake 13172, 12.1937 (NSW).

\section{L. erubescens subgroup (spp. 13-24), Map 4.}

13. L. erubescens Schauer in Lehm., Pl. Preiss. 1: 121 (1844); Benth., Fl. Austral. 3: 109 (1867) at least in part but excl. vars.

SYNTYPES: WESTERN AUSTRALIA: in glareosis sublimosis sterilibus silvae cis fl. GordonRiver (Hay), Nov. 1843: Herb. Preiss. No. 133 (dupls. MEL); in glareosis silvae haud longe a fonte St. Rozen's-well (York), Aprili sine flor: Herb. Preiss. No. 134 (n.v.); Vasse-River; Mrs Molloy (n.v., the species would not be found at this locality).

Shrub to 2 or $3 \mathrm{~m}$ tall with (as seen from specimens) close, fibrous bark later peeling in long strips; the younger stems stout with a close pubescence, at least at first, terete, without a flange, usually spreading widely from each other at c. $60^{\circ}$ and soon developing similar branching so as to give the plant a divaricately branched appearance. Leaves divergent to spreading, those subtending branches sometimes reflexed, usually 3-6 $\mathrm{mm}$ long and 2-4 mm wide, narrowly to very broadly obovate, thick and incurved or infolded, glabrous or with a few long silky hairs, with the apex rounded or almost truncate and tending to be keeled with a blunt point at the back, tapering to a virtually petioleless base that is almost umbonate at the back from the wide thick midrib-base; the leaves on younger growth often longer and lacking the characteristic base. Flowers white or pink, usually $10 \mathrm{~mm}$ or less in diameter, occurring singly or 2 together mostly in modified shoots at the ends of adjacent branches of several orders, the terminal buds developing after the flowering. Bracts usually several, broad, red-brown and rather glabrous, and often retained about a large bud; the bracteoles similar, all shed as or before the flower opens. Hypanthium usually densely silky pubescent but occasionally with the pubescence more spreading or absent, c. 2-4 mm long, the upper part not much expanded, the lower usually more densely pubescent and narrowed, often rather abruptly, to a slender pedicel often $2 \mathrm{~mm}$ or more in length, the top of the ovary with a dense short erect pubescence. Sepals persistent, c. $1 \mathrm{~mm}$ long, deltoid, pubescent but less so than the hypanthium and often dark-coloured; the margins densely ciliate. Petals c. 5. mm long. Stamens in bundles of 3-5, 1.5-2 $\mathrm{mm}$ long with many filaments very broad in the lower part, the anther-cells c. $0.4 \mathrm{~mm}$ long, parallel, broad and shallow. Style deeply inset, straight or stout-based and tapering to 

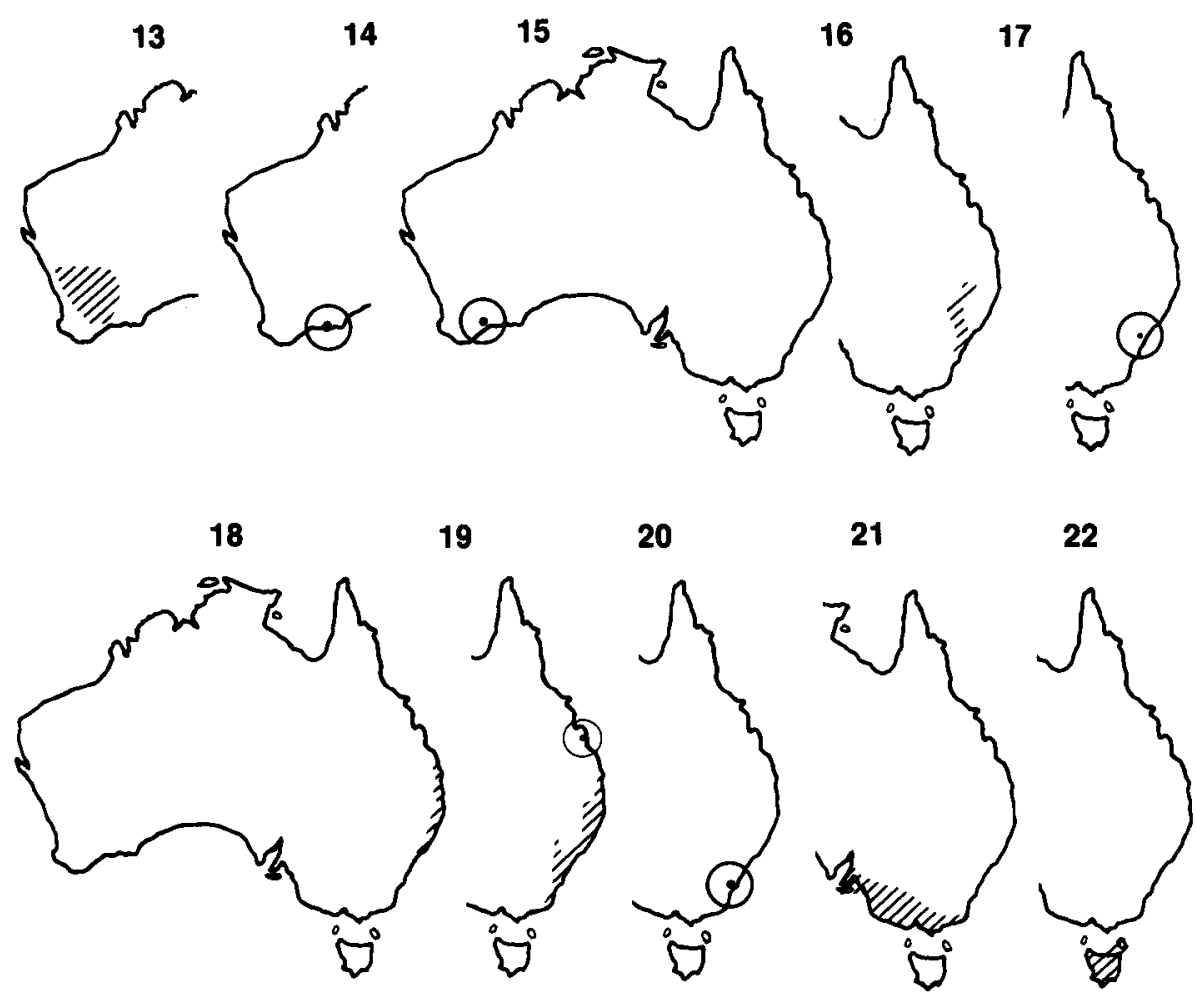

19

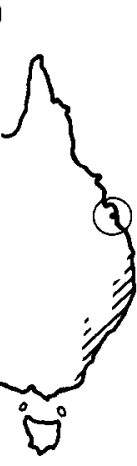

20

21

22
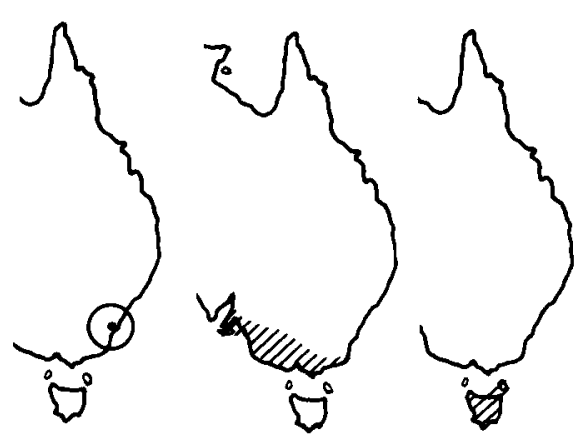

23

24
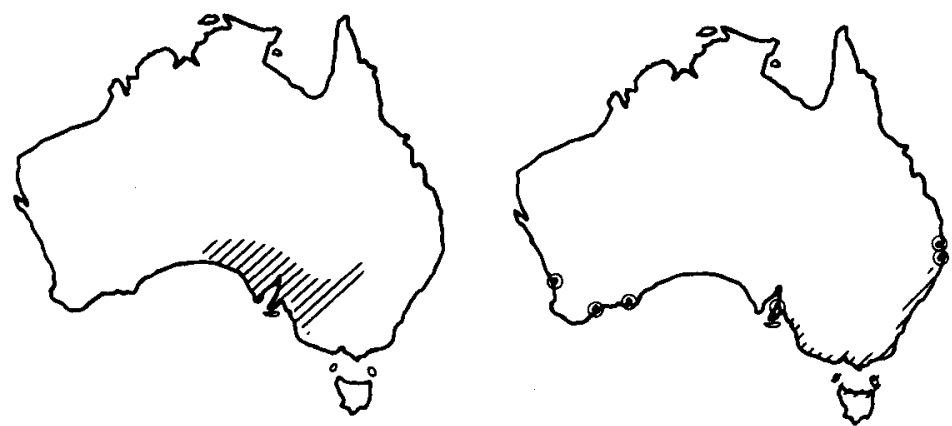

Map 4. Distribution of Group 1: subgroup 2 L. erubescens and allies. 13. L. erubescens 14. L. sericeum 15. L. confertum 16. L. parvifolium 17. L. deanei 18. L. semmibaccatum 19. L. trinervium 20. L. subglabratum 21. L. myrsinoides 22. L. glaucescens $23 . L$. coriaceum 24. L. laevigatum. 
behind the small (relative to the style) stigma. Ovary 5-locular, each loculus with c. 20 ovules in 4 rows on a broad and large placenta. Fruit deciduous, sometimes tardily, usually $4-5 \mathrm{~mm}$ in diameter, pubescent, the upper part scarcely expanded but forming an erect rim bearing the persistent incurved sepals, the lower short and abruptly contracted into an often almost inset slender stalk 1-3 mm long, the valves not woody, well exserted above the hypanthium-rim, especially near the style-base when opening and later for a distance of about half the depth of the broad part of the base. Mature seeds $1-1.5 \mathrm{~mm}$ long, obovoid-oblong with a rather shallowly reticulate surface. Main flowering period: July-Oct.

Distribution: Widespread in the Avon and Roe Districts of Western Australia and in adjoining parts of the Irwin, Darling, Coolgardie and Eyre Districts (Map 4). On sand and gravel in heath and woodland.

Selected SPECIMENS: WeStern Australia: Irwin: 7 miles [11 km] NW. of Badgingarra, Briggs NSW 154722, 10.1960 (NSW). Avon: Beringbooding, E. of Bonnie Rock, Main, 9.1957 (PERTH). Darling: 59.2 miles [95 km] from Perth towards Williams, Canning 3725, 9.1968 (CBG, NSW). Coolgardie: 29 miles [47 km] W. of Coolgardie, Phillips $024128,9.1962$ (CBG, NSW); Dundas Rocks, S. of Norseman, Thompson 4624, 10.1987 (NSW, PERTH). Roe: 18 km S. of Holt Rock, Hnatiuk 760838, 9.1976 (PERTH). Eyre: Phillips R., Highway 1, Thompson 4640, 10.1987 (NSW, PERTH); Ellens Peak, Morrison, 10.1902 (PERTH).

Specimens from some areas, especially in the Coolgardie district, have a smaller angle of branching and shorter side-shoots but are otherwise like typical L. erubescens.

14. L. sericeum Labill., Nov. Holl. Pl. 2: 9, t. 147 (1806); C.A. Gardner, J. \& Proc. Roy. Soc. Western Australia 47: 61 (1964); A. S. George, Western Australian Naturalist 10: 32 (1966).

HolotyPe: Western Australia: in capite Van-Diemen (sphalm), [Labillardière] (FI, n.v.). [C.A. Gardner had a specimen (Cape le Grand, C.A. Gardner 14117, 2. Septem. 1962 (PERTH)) matched against Labillardière's specimen in Florence and labelled it TOPOTYPE.]

SYNONYMY: Kunzea sericea (Labill.) Turcz., Bull. Soc. Imp. Naturalistes Moscou 20: 162-163 (1847).

Shrub usually 1-3 $\mathrm{m}$ in height with close bark; the younger stems stout, with a close pubescence, lacking a flange below each node, and branching at c. $45^{\circ}$. Leaves erect at first but soon diverging or reflexed, most $10-20 \mathrm{~mm}$ long and 5-10 mm wide, obovate, flat, rather thick, densely silvery-grey-pubescent at least at first with the upper surface sometimes becoming glabrous, the apex very broadly rounded but with the upper surface indented there, often with a short point behind, the base tapering and with a short broad petiole. Flowers pink, $15-25 \mathrm{~mm}$ in diameter, occurring singly or occasionally 2 together, mostly on modified shoots at the ends of short leafy side-branches in leaf-axils, the terminal buds developing with or immediately after the flowering, occasionally leaving flowers as monads at the base. Bracts few, broad, red-brown, rather glabrous and often retained about a large bud; the bracteoles similar, all shed as or before the flower opens. Hypanthium with a dense, shining, rather spreading pubescence, 4-6 $\mathrm{mm}$ long, with the upper part spreading somewhat and all tapering to a short pedicel, the top of the ovary densely pubescent with short erect hairs. Sepals persistent, 2-3 mm long, deltoid (often longer than broad), densely silky pubescent and not distinguishable from the hypanthium. Petals 
6-12 mm long. Stamens in bundles of c. 7, 3.5-4 $\mathrm{mm}$ long, the anther-cells c. $0.6 \mathrm{~mm}$ long, parallel, broad and shallow. Style well inset, broad-based and tapering to a small (relative to the style) stigma; occasionally absent. Ovary 4-6locular, each loculus with c. 20 ovules in 4 rows on a large, rather broad placenta; occasionally absent. Fruit deciduous, c. $7 \mathrm{~mm}$ in diameter, pubescent, with a broad rim bearing the persistent sepals above, and the lower part distinctly lobed in cross-section and rounded above a short stalk often $2-3 \mathrm{~mm}$ long, the valves not woody and not extending beyond the hypanthium-rim. Mature seeds 1.5-2 $\mathrm{mm}$ long, irregularly obovoid-cuneiform, the surface coarsely reticulate and with vertical rows of loose cells. Main flowering period: mostly Aug.-Sept.

DiSTRIBUTION: In the Esperance area, and on nearby islands, in Western Australia (Map 4). In shallow soil and rock crevices of windswept granite outcrops.

Selected SPECIMENS: Western Australia: Eyre: Lucky Bay (Bay 1), E. of Esperance Bay, Brown s.n., 1.1802 (NSW); West headland of Lucky Bay, Thompson 4634, 10.1987 (NSW, PERTH); walking track from Lucky Bay to Thistle Cove, Cape le Grand National Park, Powell 1872, 7.1982 (NSW); N. side of Mt Le Grand, George 11009, 9.1971 (PERTH); Cape le Grand, Gardner 14117, 9.1962 (PERTH).

\section{L. confertum $J$. Thompson sp. nov.}

Frutex 2-3 m altus. Folia conferta anguste clavata subtriquetra, $8-10 \mathrm{~mm}$ longa. Flores 12-15 mm diametro, sepalis glabratis crassis persistentibus. Ovarium 5(-7)-loculare. Fructus c. $8 \mathrm{~mm}$ diametro succulenti persistentes.

Holotype: Western Australia: East Mt Barren, K. Newbey 1730, Dec. 131964 (PERTH).

Shrub 2-3 m or more in height, usually erect, rigid and rather dense, with (as seen from specimens) gnarled firm bark marked by leaf- and branch-scars; the younger branches soon loosing a loosely appressed pubescence to become glabrous, lacking a flange but with a conspicuous small swelling below each leafbase, and with branching usually at c. $30^{\circ}$ but subsequently becoming more erect. Leaves erect and dense, mostly $8-10 \mathrm{~mm}$ long and $1-1.5 \mathrm{~mm}$ wide, very narrowly clavate and almost triquetrous, both surfaces glabrous and light green, the upper often flat, the lower somewhat keeled, broadest near the shortly acute or rounded apex, and long-tapering to a slender petiole often $1.5 \mathrm{~mm}$ long. Flowers white (rather pink in the bud), $12-15 \mathrm{~mm}$ in diameter, occurring singly in consecutive axils, on short leafless modified side-shoots that develop slowly to lengthen and flower but remain leafless. Bracts minute, pale red-brown and keeled, tending to persist below the opened flowers; the bracteoles similar but larger, c. $1 \mathrm{~mm}$ long, and shed when the bud is minute. Hypanthium rather deeply wrinkled, glabrous or with some hairs especially near the base, to c. 4-5 $\mathrm{mm}$ deep, tapering to the base but with the upper part much expanded, the top of the ovary silky-pubescent. Sepals persistent, somewhat less than $1 \mathrm{~mm}$ long, glabrous, almost hemispherical, and like the hypanthium, very thick except for the very thin margins, and hooded, overlapping in the flat bud, swollen and infolded at the base. Petals c. $5 \mathrm{~mm}$ long. Stamens in bundles of c. 7, c. $2 \mathrm{~mm}$ long, the anther-cells c. $0.5 \mathrm{~mm}$ long, parallel, broad and shallow. Style deeply inset, rather stout and straight, the stigma quite large; sometimes absent. Ovary 5 (-7)-locular, each loculus with c. 10 ovules in 2 rows on a high narrow placenta; sometimes absent. Fruit rather persistent, c. $8 \mathrm{~mm}$ in diameter, broad- and almost flat-based, the outer surface succulent and coarsely wrinkled when dry, the upper part not expanded but erect or incurved, the sepals 
persisting for some time, the valves usually shortly (to c. $1 \mathrm{~mm}$ ) exserted. Mature seeds c. 3-3.5 mm long, irregularly oblong, the outer surface of loose fibres and, before splitting, so narrowly reticulate as to appear striate. Main flowering period: (Oct.-) Dec.-Jan.

DisTRIBUTION: Apparently endemic to East Mount Barren, on the southern coast of Western Australia (Map 4). In well-drained stony quartzite sand in heath, on rock or in rocky gullies.

Selected Specimens: Western Australia: Eyre: East Mt Barren, Steedman, 12.1931 (PERTH), 1.1938 (NSW), Gardner 14869, 10.1964 (PERTH), Wilson 5466, 10. 1966 (PERTH), Crisp 5056, 1.1979 (CBG, PERTH).

The species is named for its crowded leaves.

16. L. parvifolium Smith, Trans. Linn. Soc. London 3: 263 (1797).

TyPe: New South Wales: Port Jackson, Dr White, 1795 (LINN, n.v., fide Smith in Rees, Cycl. 20 (1812)).

Synonymy: L. eriocalyx Sieber ex Sprengel, Syst. Cur. Post.: 194 (1827). TyPe: NeW South Wales: Nov. Holl., Sieber [313, fide DC., Prodr. 3: 228 (1828)] (n.v.).

Shrub to $2 \mathrm{~m}$ tall, with dense slender branches and close bark occasionally tending to flake; the younger stems with long, fine, spreading hairs or silky, and later with persisting hairs or glabrescent, without a flange but with a swelling below each node that leaves prominent leaf-scars on older branches, the branching usually at c. $45^{\circ}$. Leaves diverging, mostly 3-8 mm long and 1-3 mm wide, usually narrowly to broadly obovate, very thick, usually glabrous, flat or incurved near the apex, the apex usually obtuse and rounded but occasionally broadly acute with a blunt point, the base tapering to slender petiole often 1 $\mathrm{mm}$ or more in length. Flowers white or pink, c. $10 \mathrm{~mm}$ in diameter, usually single on condensed shoots terminating rather long, leafy side-branches, the new growth developing after flowering. Bracts few, the inner very large, redbrown and firmly chartaceous, with the bracteoles similar, all forming large cone-like buds at the ends of branches and tending to remain around the opening bud. Hypanthium usually with dense, long, irregularly spreading hairs at least on the lower part, sometimes the hairs shorter and more sparse above, c. 2-2.5 mm long, tapering but with the upper part not much expanded and the lower part broad and rounded above a short pedicel, the top of the ovary densely pubescent. Sepals persistent, 1-2 mm long, short- or long-deltoid, often somewhat pubescent, paler and thinner but otherwise similar to the hypanthium, somewhat hooded and often with a ciliate or minutely erose margin. Petals c. $4 \mathrm{~mm}$ long. Stamens in bundles of 3-5, 1-1.5 mm long, the anther-cells c. $0.3 \mathrm{~mm}$ long, parallel, broad and shallow . Style deeply inset, with hairs on the lower part, straight-sided with a small stigma. Ovary usually 5-locular, each loculus with 15-30 ovules in 4-6 rows, ascending from a small placenta attached near the base of the loculus. Fruit often held through the season before being readily shed, c. $4 \mathrm{~mm}$ in diameter, usually pubescent, widest near the conspicuous rim formed by the upper part of the hypanthium and bearing the erect or infolded sepals, and rounded above a very short stalk, the valves not woody, and exserted well above the hypanthium-rim especially near the style-base, to about halfway up the persistent sepals. Mature seeds 1-2 $\mathrm{mm}$ long, obovoid, with a shallow long-reticulate surface and sometimes vertical rows of extended cells. Flowering mostly Sept.-Nov. 
DisTRIBUTION: Widespread in eastern New South Wales from the North Western Slopes and adjoining Plains and Tablelands, through the Central Western Slopes, and Central Tablelands and Coast to the Nowra area of the South Coast (Map 4). Usually on poor sandy or gravelly soil on rocky ridges or in dry sclerophyll forest.

Selected SPecimens: New South Wales: Central Coast: Parramatta, Brown, 1804 (NSW); Frenchs Forest, Sydney, Rodway 1176, 9.1933 (NSW). South Coast: Yalwal State Forest on Yalwal-Nowra road, Coveny 10998 \& James, 9.1981 (NSW). Northern Tablelands: Emmaville, Boorman NSW 14164, 10.1911 (NSW). Central Tablelands: E. end of Mt Solitary, 5 miles [8 km] S. of Katoomba, Constable NSW 56115, 11.1960 (NSW). North Western Slopes: Warialda, Boorman NSW 14170, 10.1914 (NSW). Central Western Slopes: 8.5 miles [13 km] NE. of Gilgandra, Biddiscombe Herb. Aust. 314, 9.1954 (NSW); Currant Mtn Gap, 24 km E. of Rylstone, Coveny 9551, 9.1977 (NSW). North Western Plains: Pilliga Scrub near Narrabri, Cleland, 10.1918 (NSW).

Several robust specimens from the northern part of the range and from the Central Coast district appear to represent products of hybridisation with $L$. trinervium.

\section{L. deanei $J$. Thompson sp. nov.}

Frutex usque ad $5 \mathrm{~m}$ altus. Folia anguste elliptica ad oblanceolata, $1-1.5 \mathrm{~cm}$ longa. Flores 8-10 mm diametro, sepalis membranaceis, ex parte pubescentibus persistentibus. Ovarium 4-5-loculare. Fructus c. $3.5 \mathrm{~mm}$ diametro decidui.

Holotype: New South Wales: Devlins Creek in Pennant Hills Park, Cheltenham, 33 ${ }^{\circ}$ $45^{\prime} 30^{\prime \prime} \mathrm{S}, 150^{\circ} 05^{\prime} 00^{\prime \prime} \mathrm{E}$, Coveny 11343 \& Taylor, 11.1982 (NSW).

Shrub, often very slender, up to $5 \mathrm{~m}$ tall with bark peeling in long strips; the younger stems slender, with at least some silky hairs and with erect rather crisped short hairs or glabrous and glossy, with the flange visible only as grooves near the conspicuous node scar, and with the branching at $30^{\circ}-45^{\circ}$. Leaves divergent to spreading, mostly $10-15 \mathrm{~mm}$ long and $1-2 \mathrm{~mm}$ wide, narrowly elliptical to oblanceolate, usually glabrous, the upper surface with the margins incurved especially near the base, tapering below to a petiole-less base, the apex rather broadly acute with a blunt soft infolded point. Flowers white, c. 8-10 $\mathrm{mm}$ in diameter, occurring singly on modified shoots on slender fewleaved side-branches in consecutive axils, the new growth developing after flowering, especially strongly at the ends of branches. Bracts at least several, pale red-brown, rather firm, elliptical and forming long, narrow, pointed conelike buds; the bracteoles longer and narrower, all usually shed from the unopened bud leaving conspicuous scars. Hypanthium smooth and mostly glabrous, c. $3 \mathrm{~mm}$ long, tapering to a small, usually densely silky, pedicel and with the upper part spreading widely and longitudinally ridged, the top of the ovary silky-pubescent at least on the valve-margins. Sepals persistent, c. 1.5 $\mathrm{mm}$ long, long-deltoid, thin and pale, somewhat hooded, with hairs on the margin and at the tip. Petals c. 5 mm long. Stamens in bundles of 5-7, 1-1.5 $\mathrm{mm}$ long, the filaments with spreading hairs, the anther-cells c. $0.4 \mathrm{~mm}$ long, parallel, broad and rather shallow. Style deeply inset, slender, scarcely tapering, with short spreading hairs on the lower part, the stigma small; sometimes absent. Ovary 4-5-locular, each loculus with c. 18 ovules in 4 rows on a rather shallow placenta; sometimes absent. Fruit deciduous, c. $3.5 \mathrm{~mm}$ in diameter, mostly glabrous, the upper part of the hypanthium forming a distinct rim bearing the, at first infolded and later erect or spreading, persistent sepals, the base strongly lobed in cross-section and contracting very abruptly to a rather inset silky stalk, the thin valves raised but not beyond the hypanthium-rim 
until after opening. Mature seeds 1-1.5 mm long, obovoid-cuneiform, with a shallow-reticulate surface and often with vertical rows of looser cells. Main flowering period: Oct.-Nov.

Distribution: Limited to a small area of the Central Coast of New South Wales near the ridge between Cowan Creek and the Lane Cove River (Map 4). In sclerophyll forest.

Selected specimens: New South Wales: Central Coast: Calna Creek, 2 miles [3.2 km] W. of Kuringai, Mylrea NSW 154724, 10.1953 (NSW); Asquith, Thomas NSW 154725, 8.1951 (NSW); Pennant Hills Park, Cheltenham, Thompson 4283, 8.1982 (NSW), Coveny 10334, 11.1978 (NSW); Devlin's Creek in Pennant Hills Park, Cheltenham, Coveny 11434 \& Dunn, 12.1982 (NSW); Lane Cove [?R], Deane NSW 154726, 154727, $154728,10.1883$ (NSW). WiTHOUT LOCALITY: Leichhardt (MEL).

This species is named for Henry Deane, Railway Engineer, whose specimens, probably collected near his work on the North Shore railway, had lain in a query box for a hundred years.

18. L. semibaccatum Cheel, J. \& Proc. Roy. Soc. New South Wales 65: 203 (1932); S.T. Blake, Proc. Roy. Soc. Queensland 69: 82 (1958).

LectotyPe, here chosen: New SOUth WaLes: Wallis Island, Tuncurry, E. Cheel NSW $154729,11.5 .1925$ (NSW).

SYNONYMY: ?L. grandiflorum var. minus S. Schauer in Linnaea 15: 438 (1841). TYPE: QUEENSLAND: in Nova Hollandia ad sinum Moreton-Bay, Murray (?, n.v.).

Low dense shrub $0.5(-2) \mathrm{m}$ tall, or occasionally a small, much branched and pendulous tree, the bark close or later flaking; the younger stems with long, fine, appressed hairs and a pubescence of long appressed and/or short curled hairs persisting, without a flange but with grooves near each node, the branching at an angle of c. $30^{\circ}$. Leaves divergent, 5-10(-15) $\mathrm{mm}$ long and usually $1.5-2.5$ $\mathrm{mm}$ wide, obovate to narrowly elliptical, thick and usually flat, the surface glabrous at maturity or with a short pubescence near the base of the upper surface, with the apex in general obtuse (but occasionally somewhat acute) and blunt or with a small blunt point, and tapering at the base to a rather broad, flat (but round-based) petiole. Flowers white or pink, from less than 10 to $15 \mathrm{~mm}$ in diameter, occurring singly or 2 together in modified shoots at the ends of short leafy, few-leaved or even leafless branchlets, usually in consecutive axils on adjacent branches with new growth developing after flowering. Bracts numerous, red-brown (or sometimes pale), rather firm, with the bracteoles very large, broad, concave and scarious, all forming rather pointed cone-like buds at the ends of branches but, except for some basal bracts, shed before or as the flower opens. Hypanthium usually silky-pubescent at least in part, c. 3-4 mm long, the upper part spreading widely and usually, but not invariably, glabrous, the lower narrower tapering, densely silky and contracting rather abruptly to a short densely silky pedicel, the top of the ovary silky with dense and longer hairs around the base of the style. Sepals persistent, less than 1.5-2 mm long, somewhat oblong and obtuse, often with scarious ciliate margins, otherwise sparsely pubescent or glabrous. Petals $3.5-7 \mathrm{~mm}$ long. Stamens in bundles of $5-7$, c. $1.5-2 \mathrm{~mm}$ long, the anther-cells, c. $0.4 \mathrm{~mm}$ long, parallel, broad and shallow. Style well inset, slender and scarcely tapering with a rather small stigma; often shortened and occasionally absent. Ovary 5-, or occasionally 3or 4-, locular, each loculus with c. 24 ovules in c. 4 rows on a large but shallow placenta; occasionally absent. Fruit deciduous, often variable in size but usually 4-6 $\mathrm{mm}$ in diameter, pubescent and succulent (coarsely wrinkled in dried 
specimens), the valves densely pubescent and also rather succulent, usually above the erect upper part of the hypanthium on opening and extending little further, so as to be well below the erect or spreading sepals, forming a somewhat flat-topped fruit. Mature seeds c. $1-1.5 \mathrm{~mm}$ long, irregularly obovoidcuneiform, with a shallow to distinct reticulate surface and with several vertical rows of loose cells. Main flowering period: Aug.-Oct.

DistriBution: From the Bundaberg area of Queensland to the Forster area of New South Wales (Map 4). On sand in poorly drained coastal sandy heath.

SEleCted SPECIMENS: QueENSLAND: Wide Bay: Seary's Creek, c. 30 miles [48 km] NE. of Gympie, Everist 7778, 2.1965 (NSW). Moreton: Tugun, White 7124, 9.1930 (NSW). NEW South Wales: North Coast: Evans Head, Coveny 4669, 11.1972 (NSW); Crowdy Bay National Park, Armstrong 1164 \& Powell, 9.1977 (NSW).

\section{L. trinervium (Smith) $J$. Thompson comb. nov.}

BASIONYM: Melaleuca trinervia Smith in White, Voyage to New South Wales: 229, t. 24 (1790).

Holotype: New South Wales: [Port Jackson, White] "t. 24, Whites voyage", Sheet 878.11 (top L.H.) herb. Smith (LINN, n.v.). This specimen though sterile is identifiable from the illustration. It was matched with the lectotype of L. attenuatum Sm. by D.F. Blaxell, when Australian Botanical Liaison Officer.

SYNONYMY: Leptospermum attenuatum Smith, Trans. Linn. Soc. London 3: 263 (1797). Lectotype, here chosen: New South Wales: Port Jackson, Mr White, 1795, Sheet 878.9, R.H. specimens (LINN, n.v., photo BRI, NSW).

$L$. trinerve Smith, loc. cit., nom. nud. in synon.

L. stellatum Cav., Icon. 4: 16, t. 330, fig.2 (1797), partim, the protologue containing elements of $L$. polygalifolium. TYPE: NEW SOUTH WALES: Port Jackson, herb. Née, fl.April (MA, n.v.).

L. trinerve Smith in Rees, Cycl.: 20 (1812). TYPE: not that of Melaleuca trinervia but part of the protologue of $L$. lanigerum sensu Smith, Trans., Linn. Soc. London 3 (1797) non Sol. ex Aiton (LINN, n.v.).

L. pendulum Sieber ex Sprengel, Syst. Cur. Post 194 (1827). TyPE: New South Wales: Nov. Holl., Sieber [312, fide DC., Prodr. 3: 228 (1828)] (?, n.v.). IsoTYPE: G, photo NSW.

L. gnidiifolium DC, Prodr. 3:228 (1828). TYPE: Nouvelle Hollande, [illegible words,] 1822 (G, n.v., photo NSW).

L. stellatum Cav. var. grandiflorum Benth., Fl. Austral. 3:107 (1867). SyNTYPES: Queensland Bowman and Port Jackson, herb. F. Mueller (K, n.v.).

L. stellatum Cav. forma fallax Domin, Biblioth. Bot. 89:454 (1928). TYPE: Blue Mountains, C.T. White, 3.1910 (PRC, n.v.). IsoTYPE: BRI.

L. stellatum Cav. forma angustifolium Domin, loc. cit. TYPE: 'Parramatta', Woolls (PRC, n.v.). ?ISOTYPE: NSW.

Rigid shrub or small tree of characteristic habit (the trunk stout in proportion to rather short side-branches, probably owing to regeneration from epicormic shoots after fire), 2-5 $\mathrm{m}$ tall with the bark on the trunk and even small branches in many thin flaking layers; the younger stems rather stout, at first with a soft, long, loosely appressed or spreading, pubescence, later the pubescence short and close, without a flange, and with the branching at $\left(30^{\circ}-\right) 45^{\circ}\left(-60^{\circ}\right)$. Leaves erect to spreading, usually $10-20 \mathrm{~mm}$ long and 1-6 mm wide, broadly obovate to very narrowly elliptical and somewhat falcate, often consistent within and varying between populations and/or districts, usually silky-pubescent when young but glabrescent, the apex rounded to acuminate, usually bluntly pointed, the base tapering or rounded and scarcely or shortly petiolate. Flowers white, $7-15 \mathrm{~mm}$ in diameter, occurring singly or 2 together on condensed shoots at 
the ends of short few-leaved side-branches, in consecutive axils on adjacent branches, but with axillary monads on reversion-shoots, the new growth, sometimes developing during flowering, dense from near flowers giving a clumped appearance to the foliage, or vigorous and slender from branch-ends giving a graceful appearance. Bracts firm and brown and forming broad cone-like buds; the upper broad and concave; the bracteoles narrower; all shed before the bud opens. Hypanthium densely pubescent with wide-spreading to close silky hairs, rarely glabrous, very variable in shape, the shape, size and pubescence often but not invariably associated with the leaf-shape and consistent within and varying between populations, 3 or more $\mathrm{mm}$ in length, gradually, or sometimes abruptly, tapering into a long to very short pedicel, the upper part not widely expanded, the top of the ovary silky-pubescent. Sepals persistent, $1.5-2.5 \mathrm{~mm}$ long, usually densely pubescent, ovate-oblong to deltoid or long-deltoid, and somewhat hooded. Petals 5-7 mm long. Stamens in bundles of c. 5, 1.5-2 mm long, with some filaments broad in the lower part, the anther-cells $0.5-0.6 \mathrm{~mm}$ long, parallel, much recurved and often not opening wide. Style inset, pubescent at the base, rather stout-based and tapering to a small stigma. Ovary (3-) 4-5 locular, each loculus with c. 24 ovules in 4 rows on a high, often narrow or shallow, placenta. Fruit soon deciduous, variable in size and shape according to the leaf- and hypanthium- type, mostly 3-6 $\mathrm{mm}$ in diameter, pubescent, usually lobed in cross-section and broad and straight-sided above a short stalk, the valves thin and not exserted beyond the erect hypanthium-top with erect or occasionally spreading sepals. Mature seeds $1.5-2 \mathrm{~mm}$ long, irregularly obovoid-cuneiform, the surface coarsely reticulate with loose cells. Main flowering period: usually Sept.-Oct. (coast); Nov.-Dec. (-Jan.) (tablelands).

Distribution: In coastal districts from near Rockhampton, Queensland, to East Gippsland, Victoria, and also extending to nearby tableland areas, and the Central Western Slopes near the Hunter River, in New South Wales (Map 4). In heath, scrub and especially dry sclerophyll forest, in deep sand or shallow sandy soil among, especially sandstone, rocks.

Selected sPecimens: QueEnsland: Port Curtis: Mt Wheeler, Thozet 552 (MEL). Darling Downs: 2 miles [3.2 km] SE. of Glen Aplin, Gittins 2811, 9.1974 (NSW). Moreton: Brisbane, on the Chermside Hills, Blake 23561, 10.1970 (BRI, NSW). New SOUTH WaLES: North Coast: O.B.X. Creek, Dalmorton-Grafton road, Constable NSW 24339, 10.1952 (NSW). Central Coast: Banks of the River Grose, Brown, 1804 (NSW); Cumberland State Forest, West Pennant Hills, Coveny 8572, 10.1076 (NSW). South Coast: South Brooman State Forest, Hartley 14022, 10. 1973 (CANB, NSW). Northern Tablelands: Torrington, Boorman NSW 15023, 1.1911 (NSW). Central Tablelands: Dante Glen track, Lawson, Coveny 9843, 11.1977 (NSW). Southern Tablelands: Clyde Mtn road, c. $21 \mathrm{~km}$ SSE. of Braidwood, Adams \& Austin 2881, 12.1972 (CANB, NSW). Central Western Slopes: ... below Mt Dangar, $7.2 \mathrm{~km} \mathrm{~W}$. of Sandy Hollow, Coveny $10533 \&$ P. Hind, 12.1979 (NSW). VICTORIA: East Gippsland: Dinner Creek, Tamboon road, Lower Cann R., Melville 2886, Wakefield \& Hunter, 1.1953 (NSW).

The pattern of variation in this polymorphic species cannot be readily explained. Although the uniformity within a stand could be caused by apomixis, the variation seen in some districts (e.g. Mittagong) would require wide outbreeding, as it often includes the extreme forms with their several apparently linked characters and many intermediate forms; while the consistency in other areas (e.g. the Upper Hunter district) of an unusual form may indicate a strong response to selection pressure. Most puzzling is the occurrence in some regions (e.g. parts of the Blue Mountains) of only two extremes of observable variation, growing in a mosaic, retaining their identity and differing so much in floweringtime as not to overlap. It could be said that selection pressure has succeeded in some areas but failed in others to produce reproductively isolated forms. How ever, this is, for this genus, a distinct and successful widespread species, imme- 
diately recognisable (especially from its habit and bark type) in spite of the variability it shows in characters otherwise definitive of species. It is probable that these variations are brought about by a strong morphological response to some simple genetic alteration. Aspects of the pattern of variation in this species have been studied by Krauss (1986).

\section{L. subglabratum $J$. Thompson sp. nov.}

Frutex usque ad $2 \mathrm{~m}$ altus cortice lamellato. Folia obovata ad oblanceolata, plus minusve falcata, $1.5-3.5 \mathrm{~cm}$ longa. Flores $10-15 \mathrm{~mm}$ diametro, sepalis persistentibus, hypanthio subglabrato. Ovarium (4-) 5-loculare. Fructus 4-7 mm diametro decidui.

Holotype: New South Wales: SW. end of Shrouded Gods Mtn c. $28 \mathrm{~km}$ WSW. of Milton, $35^{\circ} 16^{\prime} \mathrm{S}, 150^{\circ} 11^{\prime} \mathrm{E}, 930 \mathrm{~m}$ alt., B.G. Briggs 3544, 23.v.1972 (NSW).

Open shrub reaching over $2 \mathrm{~m}$ in height but shorter in exposed situations, the rough bark flaking in thin layers (not always seen as such on specimens); the younger stems with sparse silky hairs, glabrescent, without a flange apart from a small grooved area near the node, slightly swollen below the node, with the branching often at $45^{\circ}-60^{\circ}$. Leaves erect to spreading, usually $15-35 \mathrm{~mm}$ long and 3-7 mm wide, oblanceolate to obovate and often somewhat falcate, flat or with the margins slightly incurved, silky-pubescent when young but glabrous at maturity except near the base, with the apex obtuse to broadly acute, usually with a short blunt, or occasionally pungent, point, flat or folded below the point, and tapering at the base to a short narrow but rather flattened petiole. Flowers white, $10-15 \mathrm{~mm}$ in diameter, occurring singly on condensed shoots at the ends of short, rather stout, leafless to few-leaved axillary branchlets in consecutive axils, the new growth limited on the short branches but produced vigorously, during flowering, from the main branch ends. Bracts numerous, firm red-brown and chartaceous, and forming a slender cone-like bud; the bracteoles thin, long and narrow; all shed from the young bud. Hypanthium for the most part glabrous but usually with a close silky pubescence on the pedicel, c. $3.5 \mathrm{~mm}$ long, the upper part spreading widely, the lower narrowing to a very slender pedicel $1-1.5 \mathrm{~mm}$ long, the top of the ovary with a short silky pubescence. Sepals persistent, 2.5-3.5 $\mathrm{mm}$ long, oblong (but appearing deltoid), glabrous except for ciliate margins, the tip keeled and hooded, all thin-textured and tending to inroll. Petals to $6 \mathrm{~mm}$ long. Stamens in bundles of c. 7, c. 2-2.5 $\mathrm{mm}$ long, with some filaments broad in the lower part, the anther-cells $0.5-0.6$ $\mathrm{mm}$ long, parallel, much recurved and not opening very wide. Style well inset with the base broad and pubescent, tapering to small (relative to the style) stigma. Ovary (4-)5-locular, each loculus with c. 24 ovules in 4 rows on a rather small (and not high) placenta. Fruit deciduous, 4-7 $\mathrm{mm}$ in diameter, glabrous for the most part, distinctly lobed in cross-section below a conspicuously wide rim and abruptly constricted at the base to a somewhat inset silky-pubescent stalk, the valves thin, raised but not exserted beyond the strongly incurved hypanthium-rim, the sepals erect or spreading but not long-persistent. Mature seeds c. 1-1.5 mm long, obovoid-cuneiform, with a coarsely reticulate surface with loose cells. Main flowering period: Dec.-Jan.

Distribution: Restricted to a small area of southern New South Wales mainly in the Budawang Range (Map 4). Usually in crevices or in shallow soil on the edge of sandstone escarpments.

Selected sPecimens: New South Wales: South Coast: North Head, Ulladulla, Cambridge 3492, 19.1911 (NSW); Mt Pigeon House, Rodway 2524, 6.1937 (NSW). Southern Tablelands: S. end Mt Owen, Briggs 3538, 4.1972 (NSW); Corang Arch, c. 18 $\mathrm{km}$ S. of Nerriga, Telford 9637, 12.1983 (CBG, MEL, NSW). 
21. L. myrsinoides Schldl, Linnaea 20: 653 (1847).

Holotype: South Australia: in sandigen Gegenden im Pine-forest-Walde, zwischen dem Gawler - und Lightriver, Behr (?HAL, n.v.).

SYNONYMY: L. myrsinoides var. angustifolium Miq., Ned. Kruidk. Arch. 4: 143 (1859). TYPE: not designated.

L. myrsinoides var. latifolium Miq., loc. cit. TYPE: not designated.

Shrub, usually compact, 1-2 m tall, with firm bark; the younger stems glabrescent, without a flange but conspicuously swollen below the node, the branching at a variable angle of $30^{\circ}-60^{\circ}$. Leaves divergent to spreading and with the apex tending to recurve, 5-10 $\mathrm{mm}$ long and $1-3 \mathrm{~mm}$ wide, usually narrowly obovate to oblanceolate, glabrescent, the margins incurved especially near the apex and usually minutely tuberculate, the apex acute with a blunt point, the base tapering to a short petiole. Flowers white or pink, $10-15 \mathrm{~mm}$ in diameter, on modified 1- (or occasionally 2-) flowered shoots at the ends of short, often rather stout, few-leaved side-branches, in consecutive axils on adjacent branches, the pubescent new growth appearing mostly near the ends of branches late during, or after, flowering. Bracts at least several, broad redbrown and rather firm, forming a pointed cone-like bud at branch-ends; the bracteoles large but more scarious; all falling before the bud opens, leaving prominent scars, or a few persisting about the open flowers. Hypanthium silkypubescent and usually, but not invariably, with the upper part glabrous and expanded, c. $4 \mathrm{~mm}$ long, broad, and tapering to the base or rounded above a very short pedicel, the top of the ovary silky-pubescent at least near the stylebase. Sepals persistent, c. $0.5 \mathrm{~mm}$ long, very shortly deltoid, thin pale and glabrous, continuous with, but different in texture from, the hypanthium. Petals c. 4-5 mm long. Stamens in bundles of (3-)5, c. $4 \mathrm{~mm}$ long, the anther cells c. 0.6-0.7 mm long, parallel, somewhat folded back and recurved, and shallow. Style well inset, slender with the stigma small, relative to the style; often absent. Ovary usually 4-5-locular, each loculus with c. 30 ovules in 4 or more rows on a large broad but shallow placenta; often absent. Fruit deciduous, 4-6 mm in diameter, the outer surface often succulent, widest at the erect hypanthium-rim and rounded at the base above or without a short stalk, the valves not very woody, usually extending above the erect rim and its short erect sepals. Mature seeds c. $1.2 \mathrm{~mm}$ long, broadly obovoid cuneiform, rather flattened, with a reticulate surface and sometimes rows of loose cells. Main flowering period: Oct.-Nov.

DisTRIBUTION: From the Mt Lofty Ranges and Kangaroo Island of South Australia to the Far South Coast of New South Wales (Map 4). In sandy, and often swampy, soils of coastal heath and inland heath and mallee.

Selected sPecimens: New South Wales: South Coast: Womboyn, Constable NSW 30962, 10.1954 (NSW). VICTORIA: East Gippsland: c. 8 miles [13 km] SE. of Sale, Salasoo 4827, 10.1971 (NSW). Port Phillip: Royal Botanic Gardens Annexe, Cranbourne, Ross 2570, 11.1981 (HO, MEL, NSW); Arthurs Seat, Port Phillip, Brown, 1.1804 (NSW). Northern Plains: "Whipstick Mallee Scrub", 18 miles [29 km] NNE. of Bendigo, Constable 5235, 10.1964 (NSW). Western Highlands: 38 miles [62 km] from Horsham towards Halls Gap, Wrigley CBG 031347, 12.1968 (NSW). West Coastal Plains: scarp of Glenelg R. gorge, c. 5 miles [8 km] NW. of Nelson, Melville 1564, Beauglehole, Finck \& Finck, 10.1952 (NSW): South Australia: South-eastern: 4 miles [6.5 km] from Frances, towards Bordertown, Wrigley CBG 036327, 11.1968 (CBG, NSW). Southern Lofty: Millbrook, Torrens Gorge, Cheel NSW 154737, 8.1924 (NSW). Kangaroo Island: Middle R., Ashby 762, 10.1905 (NSW). 
22. L. glaucescens S. Schauer, Linnaea 15: 420 (1841); Willis, Muelleria 1: 136 (1967).

NeotyPe: Tasmania: Western foot of Strzelecki Peaks, S.W. Flinders Island, Bass Strait ..., J.H. Willis, 10 Apr. 1954 (MEL) fide Willis, Muelleria 1: 136 (1967). ISONEOTYPES: HO, NSW

SYNONYMY: Eriostemon? trinerve Hook., J. Bot. (Hooker) 1: 25-4 (1834) non Leptospermum trinerve (Smith) Smith. HolOTYPE: TASMANIA: Lawrence 91, 1831 (K, n.v.).

L. erythrocarpum Summerh. \& Comber in Comber, Field Notes Tasman. Pl. 1929-30:19, 51 (1930). Holotype: TASmania: Coles Bay, east of Swansea, at Hazards, 300m alt; Comber 2322, April 20, 1930 (K, n.v.).

Shrub or small tree with (as seen on specimens) close flaky bark; the younger stems with dense, long and/or short, crisped hairs but often eventually glabrous, without a flange but grooved from the edge of the node with no swelling below it, the branching usually at c. $45^{\circ}$. Leaves divergent to spreading, (5-) c. 10 $(-20) \mathrm{mm}$ long and mostly 3-6 (-8) $\mathrm{mm}$ wide, elliptical (often broadly so) to obovate, almost flat or with margins somewhat incurved especially near the apex and base, sometimes thick, often grey-green, glabrous or with some areas of a short pubescence, the apex very shortly acute and sometimes tending to show a blunt point, the base tapering to a distinct pale, occasionally pubescent, petiole c. $1 \mathrm{~mm}$ long. Flowers white, c. $15 \mathrm{~mm}$ in diameter, occurring as axillary monads in consecutive leaf-axils on relatively unmodified adjacent shoots, usually with several bract-scars at the base of the shoot, occasionally the lowest subtended by bracts, or on condensed shoots terminal on short branchlets, the new growth extending vigorously from the ends of the branches and less vigorously from shorter side-shoots, often during flowering. Bracts red-brown, thin but thickened at the base, and readily deciduous, usually more numerous than the flowers; the bracteoles so evanescent as to be rarely seen. Hypanthium densely silky-pubescent with long white hairs, or occasionally sparsely pubescent, especially near the top, $3-3.5 \mathrm{~mm}$ long, the upper part much expanded, the lower often fluted, tapering to the base or to above a relatively stout pedicel, the top of the ovary with a close silky pubescence. Sepals persistent, usually $1.5-2.5 \mathrm{~mm}$ long, broadly ovate to long-deltoid, silky pubescent at least in part, with scarious densely ciliate margins. Petals $4-7 \mathrm{~mm}$ long. Stamens in bundles of 5-7, rather irregular, c. $1.2-1.5 \mathrm{~mm}$ long, the anther cells to $0.5 \mathrm{~mm}$ long, parallel broad and shallow. Style well inset, and with some hairs at the base, slender, with a rather small stigma. Ovary 4-6-locular, each loculus with c. 10 ovules in 2 rows on a narrow and rather shallow placenta. Fruit tending to persist but not long-persistent, usually $4-5 \mathrm{~mm}$ in diameter, the outer surface rather glaucous, often becoming succulent, the upper part of the hypanthium usually extended and infolded bearing the persistent rather erect sepals, the lower part broadly rounded above a very short stalk, but becoming virtually sessile on older branches, the valves not woody, often extending somewhat but to form a rather flat-topped fruit. Mature seeds c. 1-1.5 mm long, rather flattened, obovoid-cuneiform, the surface shallowly reticulate often with vertical rows of loose cells, some so developed as to form a vestigal wing. Main flowering period: Jan.-Feb.

DisTRIBUTION: Widespread in Tasmania (Map 4). In wet coastal and mountain heaths.

Selected SPECIMENS: TASMANIA: $6 \mathrm{~km}$ from Strahan on Strahan-Queenstown road, Orchard 5374, 2.1981 (HO, MEL, NSW); Robbin Is., Gunn 679/1842, 10. 1837 (NSW); Lake Vera, Frenchmans Cap, Salkin NSW 154738, 2.1978 (NSW); banks of the Huon R., Brown, 5.1804 (NSW); c. 1/2 mile [0.8 km] from Hastings, towards Strathblane, 
Canning 2450, 2.1969 (CBG, NSW); Freycinet Pensinsula National Park, 4 km S. of Coles Bay township ..., Short 1893, 2.1983 (HO, MEL).

Specimens of this species have been wrongly identified as L. myrtifolium Sieb. ex DC. or L. sericeum Labill. by many authors.

23. L. coriaceum (F. Muell. ex Miq.) Cheel, J. \& Proc. Roy. Soc. New South Wales 57: 128 (1923).

Basionym: Fabricia coriacea F. Muell. ex Miq., Ned. Kruidk Arch. 4: 147 (1859).

HolOtYPE: SOUTH AUSTRALIA: In fruticetis locorum arenosorum Murray-scrub fluvii ostium versus, $F$. Mueller (U, n.v.). ISOTYPE: MEL.

SYNONYMY: L. laevigatum var. minus F. Muell. ex Benth., Fl. Austral. 3: 103 (1867). HOLOTYPE: as for $F$. coriacea.

Spreading shrub to $2 \mathrm{~m}$ tall with close but probably ultimately shed bark; the younger stems with fine, silky hairs but soon glabrous, the surface rather smooth and pale, lacking a flange but grooved from beside the node and swollen below it, the branches usually erect but the angle of branching varying, usually from $30^{\circ}-45^{\circ}$. Leaves divergent, often quite widely so, usually 10-20 $(-30) \mathrm{mm}$ long and 3-5 mm wide, ovate to oblanceolate or elliptical, flat, rather thick, and glabrous at maturity, the apex acute to obtuse or shortly acuminate, with a short point, the base tapering to a short rounded petiole. Flowers white, $12-15 \mathrm{~mm}$ in diameter, usually 2 (of disparate age) together on short modified shoots that are terminal and close in the leaf-axils, the new growth usually developing as a prolongation of the branches during flowering with little development of the flowering shoots. Bracts numerous, broad and pale red-brown, forming broad cone-like buds in the leaf-axils and often persisting about the flower; the bracteoles narrower than the broad inner bracts and deciduous. Hypanthium glabrous or silky, 2-3 mm long, broad, especially the upper part, and tapering to the base, the top of the ovary with a short silky pubescence or glabrous, the valve-margins showing as pale lines. Sepals persistent, $1.5-2 \mathrm{~mm}$ long, deltoid, rather thin in texture and paler than the hypanthium, glabrous apart from very long hairs at and near the top or somewhat silky-pubescent. Petals 5-7 mm long. Stamens in bundles of 5-7(-9), 1-2 $\mathrm{mm}$ long, rather irregular, the anther-cells variable, to $0.5 \mathrm{~mm}$ long, parallel, broad and shallow. Style inset, slender and often with some short hairs at the base, with the stigma, relative to the style, large; sometimes absent. Ovary 4- to more than 7-locular, each loculus with 7-9 ovules in 2 rows on a very narrow and rather high and shallow placenta; sometimes absent. Fruit deciduous but often only tardily, 5-8 $\mathrm{mm}$ in diameter, the outer surface turgid and becoming wrinkled, widest at the erect hypanthium-rim from which the sepals are soon shed, below this rather straight-sided, lobed in cross-section, broad-based and sessile, the valves rather rigid, exserted somewhat above the rim but so as to form a flat-topped fruit. Mature seeds c. 1.5-2 $\mathrm{mm}$ long, flattened and broadly obovoid-cuneiform, the surface broadly and somewhat coarsely reticulate and with rows of loose cells often extended into marginal wings. Main flowering period: June-Oct.

Distribution: Widespread from the Ooldea district of South Australia to northwestern Victoria and southwestern New South Wales (see Map 4). In mallee and on dunes.

Selected SPeCimens: New South Wales: South Western Plains: $105 \mathrm{~km} \mathrm{NE}$. of Ivanhoe, Milthorpe 2614 \& Cunningham, 8.1974 (NSW). South Far Western Plains: 6 miles [10 km] E. of "Lethero", NE. of Wentworth, Briggs 2786, 5.1969 (NSW). VICTORIA: Mallee: Eastern Lookout, Wyperfield National Park, Briggs 2878, 10.1969 
(NSW). South Australia: Eyre Peninsula-Nullarbor: N. of Fowlers Bay, Giles s.n., 1875 (MEL). Murray: Murray Bridge, Maiden NSW 154741, 1.1907 (NSW).

24. L. laevigatum (Gaertner) F. Muell., Ann. Rep. of the Government Botanist and Director of the Botanic Garden, Victoria: 22 (1858), Fragm. 4: 60 (1883-4).

BASIONYM: Fabricia laevigata Gaertner, Fruct. Sem. P1. 1: 175 (1788).

Holotype: New South Wales: Banks \& Solander ex Herb. Banks, (BM, n.v.). ?IsotyPE: NSW.

Shrub or small tree, often reaching more than $4 \mathrm{~m}$ in height, with close bark that tends to be shed in strips from the older trunks; the younger stems usually rather stout, with long silky hairs but soon becoming glabrous, rather smooth and pale with grooves from beside the extended node and a swollen area just below it, and with branching often at c. $45^{\circ}$. Leaves divergent, often widely so, 15-30 mm long and 5-8 $\mathrm{mm}$ wide, usually narrowly obovate and often rather thick-textured, flat, glabrous at maturity, the apex broadly obtuse with a small, often infolded, point, the base tapering to a short rather flattened petiole. Flowers white, usually $15-20 \mathrm{~mm}$ in diameter, usually 2 (of disparate age) together on short modified shoots that are terminal and close in the leaf-axils, the new growth usually developing as a prolongation of the branches during flowering with little development from flowering shoots. Bracts numerous, broad, pale red-brown, forming broad cone-like buds in the axils, and with the bracteoles somewhat narrower, most shed before the flower opens but some often persisting about the open flower. Hypanthium usually glabrous but occasionally with an appressed silky pubescence, more sparse on the upper part, 3-4 $\mathrm{mm}$ long, with the upper part expanding widely, tapering below but rather rounded above a short often turgid pedicel, the top of the ovary with a short silky pubescence, the valve-margins showing as pale lines. Sepals persistent, c. 2 $\mathrm{mm}$ long, deltoid, longer or shorter than broad, thin in texture with at least the margins paler than the hypanthium, almost glabrous but usually with long rather crimped hairs near the margin. Petals $5-8 \mathrm{~mm}$ long. Stamens in bundles of 5-7, 1.5-2.5 mm long, rather irregular, the anther-cells variable, often $0.6-1$ $\mathrm{mm}$ long, parallel, somewhat folded back and recurved, and shallow. Style inset, slender apart from a stout base, with a relatively large stigma; sometimes absent. Ovary usually 6-11-locular, each loculus with c. 15 ovules in 2 rows on a very narrow and rather high and shallow placenta; sometimes absent. Fruit deciduous but sometimes tardily so, usually $7-8 \mathrm{~mm}$ in diameter, the outer surface turgid and becoming wrinkled, widest at the erect hypanthium-rim from which the sepals are soon shed, below this, rather straight-sided, lobed in cross-section, broad-based and usually with a very short stalk, the valves rather rigid, exserted somewhat above the rim but so as to form a flat-topped fruit. Mature seeds c. $2.5 \mathrm{~mm}$ long, broadly ovoid-cuneiform and flattened, the surface broadly and shallowly reticulate and usually with rows of extended cells forming a broad marginal wing. Main flowering period: Aug.-Oct.

Distribution: On the coast from the Nambucca R., New South Wales, to the Bass Strait Islands and northern Tasmania, perhaps reaching South Australia (Map 4). The natural western limit of the species is a matter of conjecture. It is now well established in southern Queensland (by sandminers), in Western Australia (perhaps from ballast), and in many localities including parts of South Australia (as garden escapes and coastal plantings). On beach sand and dunes and on coastal cliffs. 
Selected SPeCimens: New South Wales: North Coast: Grassy Head (near Macksville), Johnson 7863, 1.1975 (NSW). Central Coast: Botany Bay, Brown, 8.1803 (NSW). South Coast: Disaster Bay, Constable NSW 30233, 10.1954 (NSW). Victoria: East Gippsland: SE. of Sale, sand dunes at Letts Beach (90 Mile Beach), Salasoo 4916, 10.1971 (NSW). Port Phillip: Brighton Beach, Clifford, Rodway No. 11266, 5.1947 (NSW). Tasmania: Long Point, Flinders Island, Whinray 2441, 9.1978 (MEL, NSW); Petal Point, Moscal 3218, 10.1983 (HO); Marrawah, Curtis, 5.1947 (HO). SOuth Australia: Southern Lofty: Granite Island, Victor Harbor, Briggs NSW 154742, 8.1958 (NSW).

\section{L. brevipes subgroup (spp. 25-38), Map 5.}

25. L. nitens Turcz., Bull. Cl. Phys.-Math. Acad. Imp. Sci. Saint-Pétersbourg 10: 325 (1852).

Holotype: Western Australia: Drum[mond] [Coll.] $V, n .28$. (?KW, n.v.). Isotypes: NSW, PERTH

SYNONYMY: L. erubescens var. strictum Benth., Fl. Austral. 3: 109 (1867) p.p., in regard to Drummond, 5 th Coll. Suppl. n. 28 (K, n.v.).

Slender shrub to c. $3 \mathrm{~m}$ in height with numerous erect branches and bark, as seen on specimens, fibrous and close but shedding thread-like pieces; the younger stems silky-pubescent, lacking any flange but grooved at the node and extended below it, the branching usually at c. $30^{\circ}$. Leaves diverging, 5-12 mm long and $1.5-3.5 \mathrm{~mm}$ wide, very narrowly obovate-cuneate to obovate, rather firm and at first grey-silky-pubescent though later often more, but rarely completely, glabrous, somewhat incurved in cross-section with the margins thick especially near the apex, the apex usually broadly rounded or very broadly acute but with a small blunt point behind, the base usually very long-tapering to a short petiole but sometimes short-tapering. Flowers white or pink, c. 7-12 $\mathrm{mm}$ in diameter, usually 1 or $2(-3)$ on short modified shoots that are axillary or at the ends of short leafless or few-leaved side-branches close in the axils of adjacent leaves, the new growth vigorous at the ends of branches, minimal from the flowering shoots. Bracts few, red-brown and scarious; with the bracteoles much longer than wide; all shed from the young bud. Hypanthium with a shining, silky, mostly appressed pubescence, c. 2-3 $\mathrm{mm}$ long, tapering at first rather evenly but below the ovary more abruptly to a long, somewhat fluted or ribbed, tapering, pedicel c. $2 \mathrm{~mm}$ or even more in length, the top of the ovary silky. Sepals persistent, 1.5-2 mm long, deltoid, densely silky-pubescent and similar to the hypanthium, the apex somewhat infolded and hooded. Petals $\mathrm{c}$. $3-5 \mathrm{~mm}$ long. Stamens in bundles of (3-)5, c. $2 \mathrm{~mm}$ long, the filaments broad in the lower part, the anther-cells c. $0.4 \mathrm{~mm}$ long, parallel, broad and shallow. Style well inset, rather stout, tapered below a small (relative to the style) stigma. Ovary 4-5-locular, each loculus with c. 20 (16-28) ovules in 4 rows on a rather small placenta. Fruit readily deciduous, $2.5-4 \mathrm{~mm}$ in diameter, the outer surface pubescent, widest in the upper part with the erect upper part of the hypanthium bearing somewhat incurved sepals, the lower part lobed in crosssection, and the base rounded above a narrow stalk, the valves thin, and exserted beyond the erect upper part of the hypanthium on opening. Mature seeds $1 \mathrm{~mm}$ long, obovoid, the surface very coarsely reticulate. Main flowering period: Aug.-Sept. 
Distribution: In the central part of the Avon and western part of the Roe and Eyre Districts of Western Australia (Map 5). In sand and gravel, especially among granite rocks.

SElECTED SPECIMENS: WeSTERn AuSTRAlia: Avon: Yorkrakine, Gardner B 1557, 8.1920 (PERTH). Roe: Tarin Rock, Beard 2153, 10.1962 (PERTH); montem Madden, Gardner 13993, 8. 1962 (PERTH). Eyre: crossing of Phillips R., c. $15 \mathrm{~km} \mathrm{SW.} \mathrm{of} \mathrm{Ravensthorpe}$ on main road to Ongerup, Haegi 1038, 9.1976 (AD, PERTH), Thompson 4641, 10.1987 (NSW, PERTH).

\section{L. roei Benth., Fl. Austral. 3: 110 (1867).}

Holotype: Western Australia: in the interior, Roe (K, n.v.). Koch 2770 (PERTH) was matched with the Type by C.A. Gardner in 1938.

Spreading shrub to $2 \mathrm{~m}$ or more tall, with erect rather slender branches and bark, as seen on specimens, close but shedding fibres; the younger stems with dense or sparse, long, silky hairs and later with these more sparse or absent, with a vestigial flange just below the node and the stem thickening below, the branching at $30^{\circ}$ or even less. Leaves diverging, usually 7-13 $\mathrm{mm}$ long and 2-3 $\mathrm{mm}$ wide, elongate-obovate to narrowly cuneate, infolded or incurved with thick margins especially near the apex, often silky-pubescent on both surfaces but when older sometimes glabrous, the apex rounded or somewhat acute, often recurved and usually with a small umbo at the back, the base tapering gradually usually to a rounded pale petiole up to c. $1 \mathrm{~mm}$ long, but sometimes sessile. Flowers white or pink, usually $10-13 \mathrm{~mm}$ in diameter, 1 or 2 on short modified shoots in adjacent leaf-axils or on the ends of adjacent short few-leaved sidebranches, the new growth developing during flowering, strongly from the ends of branches but minimal from the flowering shoots. Bracts few, pale red-brown and scarious; with the bracteoles much longer than wide; all shed from the young bud. Hypanthium with a dense silky and mostly spreading pubescence, occasionally more glabrous on the upper part, c. 3-4 $\mathrm{mm}$ long, the upper part not much expanded, tapering a little, and below the ovary more abruptly to a long, tapering somewhat fluted or ribbed pedicel $1.5-2.5 \mathrm{~mm}$ long, the top of the ovary with a dense short velvety tomentum. Sepals persistent, 1-1.5 mm long, deltoid, undifferentiated except in their darker colour and sometimes sparser tomentum from the hypanthium, the apex tending to be hooded. Petals usually c. $5 \mathrm{~mm}$ long. Stamens in bundles of (1-) 3-5 (-7), c. $2 \mathrm{~mm}$ long, with some filaments rather broad in the lower part, the anther-cells c. 0.4-0.5 mm long, parallel, broad and shallow. Style well inset, with a few hairs on the broad base, and tapering behind a small (relative to the style) stigma. Ovary 3-4(-5)locular, each loculus with c. 20 ovules in 4 rows on a rather small placenta. Fruit readily deciduous, $2.5-3$ or more $\mathrm{mm}$ in diameter, the outer surface with a dense silky pubescence, the erect upper part of the hypanthium forming a somewhat wider rim bearing erect to incurved sepals, the lower part lobed in cross-section, and rounded above a narrow stalk, the valves thin, exserted at first to the height of the rim but extending somewhat further after the opening. Mature seeds c. $0.75 \mathrm{~mm}$ long, cuneiform, the surface (? mature) very coarsely reticulate. Main flowering period: Aug.-Oct.

DiSTRIBUTION: In the central part of the Avon District of Western Australia and in the adjoining part of the Coolgardie District (Map 5). On sand or gravel or on granite outcrops.

SElected SPECIMENS: Western Australia: Avon: c. $14.5 \mathrm{~km}$ NE. of Wubin on road to Paynes Find, Haegi 1115, 9.1976 (NSW, PERTH); near Bencubbin, Ashby 3595, 9.1970 

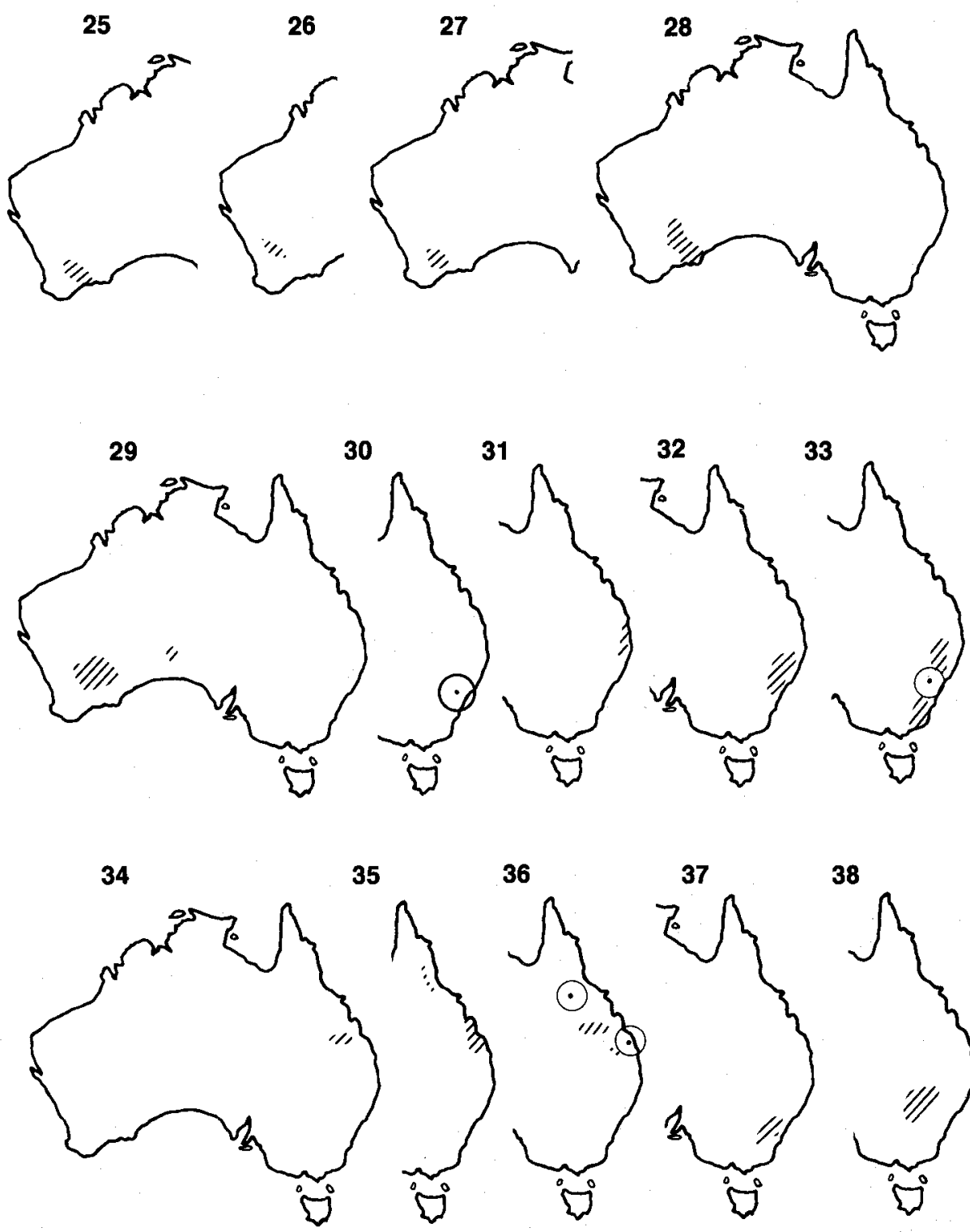

38

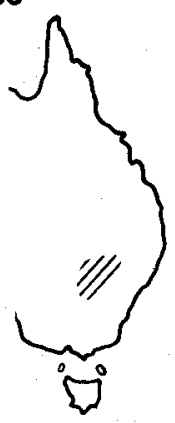

Map 5. Distribution of Group 1: subgroup 3 L. brevipes and allies. 25. L. nitens $26 . L$. roei 27. L. inelegans 28. incanum 29. L. fastigiatum 30. L. blakelyi 31. L microcarpum 32. L. polyanthum 33. $L$ brevipes 34. L. sericatum 35. $L$. neglectum 36. L. lamellatum 37. L. multicaule 38. L. divaricatum. 
(PERTH); Merredin, Koch 2770, 9.1923 (NSW); Muntagin, Bailey 169, 9.1947 (PERTH). Coolgardie: Bullinch, NNW. [as NNE.] of Southern Cross, Rogerson 319, 10.1966 (PERTH); Bodallin, Thompson 4612, 10.1987 (NSW, PERTH).

Many authors have used this name in a broad sense so as to include other species, especially L. fastigiatum.

\section{L. inelegans $J$. Thompson sp. nov.}

Frutex effusus usque ad $2 \mathrm{~m}$ altus. Folia obovata ad anguste elliptica, $0.5-1.5$ $\mathrm{cm}$ longa. Flores $7-10 \mathrm{~mm}$ diametro, sepalis pubescentibus persistentibus. Ovarium 3-5-loculare. Fructus 3-4 mm diametro decidui.

Holotype: Western Australia: $40 \mathrm{~km}$ E. of Lake King, ca $33^{\circ}$ [as $30^{\circ}$ ] $00^{\prime} \mathrm{S}$ lat. $120^{\circ}$ [as 121] 07' E long., R. Hnatiuk 760783, 17 Sept. 1976 (PERTH).

Straggling shrub to $2 \mathrm{~m}$ tall with erect slender branches and bark, as seen on specimens, close but with occasional loose fibres; the younger stems with areas of long, fine appressed hairs and glabrous areas, with the flange virtually absent but the stem extended very conspicuously below each node, the branching irregular, at c. $40^{\circ}$ or less. Leaves somewhat variably divergent, usually 5-15 $\mathrm{mm}$ long and $2-3 \mathrm{~mm}$ wide, obovate and often very elongate at the base, to narrowly elliptical, those of the upper branches often much shorter and more sparse, rather thick, especially near the apex, the surface incurved, densely silky-pubescent at first but often later becoming glabrous, the apex rounded or more usually acute, tending to infold and with an umbo at the back, the base very variable in the amount of taper and the length of the 0-2 $\mathrm{mm}$ long slender petiole. Flowers white or pink, usually $7-10 \mathrm{~mm}$ in diameter, single or occasionally 2 on short condensed shoots in adjacent leaf-axils of young growth and at the ends of short adjacent axillary branches in subsequent seasons, the new growth at the ends of some branches vigorous, but mostly tardy and minimal on side branches of the previous season. Bracts few, pale red-brown and scarious, both bracts and bracteoles longer than broad, and usually but not invariably shed early. Hypanthium densely pubescent with white appressed, or occasionally spreading, hairs, c. 2-3 mm long, the upper part not expanded, the lower abruptly contracting to a pedicel c. $1 \mathrm{~mm}$ long, the top of the ovary with a close velvety pubescence. Sepals persistent, c. $2 \mathrm{~mm}$ long, deltoid, often about twice as long as broad, the apex somewhat hooded, all pubescent as the hypanthium. Petals c. $3 \mathrm{~mm}$ long. Stamens in bundles of $1-5,1 \mathrm{~mm}$ or less in length, the filaments very broad in the lower part, the anther-cells c. $0.3 \mathrm{~mm}$ long, parallel, broad and shallow. Style well inset, stout, with the stigma rather small. Ovary 3-5-locular, each loculus with c. 20 ovules in 4 rows on a rather small placenta. Fruit not persisting, 3-4 $\mathrm{mm}$ in diameter, the outer surface pubescent, the upper part of the hypanthium angled inward and contracted over the top with the persistent sepals erect or spreading and incurved, the lower part lobed in cross-section and rounded above a short stalk, the valves thin, and extending upward but within the upper part of the hypanthium. Mature seeds c. $0.75 \mathrm{~mm}$ long, obovoid-cuneiform, the surface broadly and at length shallowly reticulate. Main flowering period: Sept.-Nov.

DISTRIBUTION: In the western part of the Roe District of Western Australia and in adjacent parts of the Eyre District (Map 5). Usually in scrub or heath on sand or gravel.

Selected SPeCIMENS: WeStern Australia: Roe: $7.5 \mathrm{~km}$ WSW. of Lake Cronin, Houston 203-17, 10. 1978 (PERTH); 60 miles [97 km] W. of Kumarl, Blackall 1254, 11.1931 (PERTH). Eyre: 16.5 miles [27 km] N. of Ravensthorpe George 309, 9.1959 (PERTH). 
This species is named for its habit which is described on many specimens as "straggling".

28. L. incanum Turcz., Bull. Cl. Phys.-Math. Acad. Imp. Sci. Saint-Pétersbourg 10: 335 (1852).

HOLOTYPe: Western Australia: Drum/mond] [Coll.] $V, n .130$ (?KW, n.v.). IsOTYPes: NSW, PERTH.

SYNONYMY: L. erubescens var. strictum Benth., Fl. Austral. 3: 109 (1867) p.p., in regard to Drummond 5th Coll. $n$. 130 (K, n.v.).

Compact shrub usually 1-2 m tall with slender erect branches and bark, as seen on specimens, close or lifting irregularly; the younger stems with sparse or dense, fine, appressed hairs, without a flange but with a slightly thickened area beside and a little below each node, and with the branching at c. $\left(40^{\circ}-\right) 30^{\circ}$ Leaves erect to divergent (5-)c. $15(-20) \mathrm{mm}$ long and usually $2-5 \mathrm{~mm}$ wide, elongate-obovate, broadest near the apex and tapering to the base, rather thick, incurved or infolded especially near the apex, and with an appressed silky pubescence or glabrous, the apex rounded or somewhat acute, tipped by a recurved blunt point, the base usually tapering gradually to a short slender petiole. Flowers white or pink c. 10-15 $\mathrm{mm}$ in diameter, 1-2(-3) together on short condensed shoots in leaf-axils and terminal on short condensed shoots in leaf-axils and terminal on short few-leaved axillary branches, the new growth produced vigorously from branch-ends during or even before flowering, also precocious but less vigorous from side-branches. Bracts few and bracteoles narrow, all small pale red-brown and scarious, and shed long before the bud develops. Hypanthium with an appressed silky pubescence, often c. $3 \mathrm{~mm}$ in length, the upper part conspicuously expanded, the lower gradually tapering to an itself tapering rather fluted pedicel usually $3-5 \mathrm{~mm}$ in length, the top of the ovary silky-pubescent. Sepals persistent, c. 1-2 mm long, deltoid, often longer than broad, somewhat hooded, spreading, differentiated only in colour from the hypanthium. Petals c. $5 \mathrm{~mm}$ long. Stamens in bundles of c. 5, c. 1.5-2.5 mm long, with a few filaments somewhat broad in the lower part and, rarely, with a few hairs, the anther-cells c. $0.4 \mathrm{~mm}$ long, parallel, broad and shallow. Style well inset, not very stout, with a medium-sized stigma. Ovary 3-5-locular, each loculus with c. 20-30 ovules in c. 4-6 rows in a shallow but not small (longer than broad) placenta. Fruit not persisting, c. 3-3.5 $\mathrm{mm}$ in diameter, usually with a sparse silky pubescence, the upper part expanded but the hypanthiumtop erect or somewhat incurved and bearing the erect persistent sepals, the lower part somewhat lobed in cross section and tapering to a long-tapering stalk often $5 \mathrm{~mm}$ or more in length, the valves thin, not, or not much, exserted beyond the hypanthium on opening but later usually equal to, or slightly above, it. Mature seeds c. $1 \mathrm{~mm}$ long, obovoid, with a strong reticulate pattern. Main flowering period: July-Dec.

DisTRIBUTION: From south of Coolgardie through the western part of the Roe and Eyre Districts of Western Australia to the south coast (Map 5). On granite outcrops.

Selected specimens: Western Australia: Coolgardie: Knopp Rock ... HydenNorseman road, Marchant 71/552, 9.1971 (PERTH); Dundas Rocks, S. of Norseman, Thompson 4625, 10.1987 (NSW, PERTH); Moirs Rock, c. $70 \mathrm{~km}$ SW. of Norseman ..., Haegi 953, 9.1976 (NSW). Roe: Mt Ney, Beard 6391, 9.1970 (NSW, PERTH). Eyre: 11 miles $[18 \mathrm{~km}] \mathrm{N}$. of Esperance, Gardner 2808, 10.1931 (PERTH); ... c $10 \mathrm{~km} \mathrm{ESE.} \mathrm{of}$ Howick Hill, Donner 2643, 9.1968 (AD, PERTH). 
29. L. fastigiatum S. Moore, J. Linn. Soc., Bot. 45: 201 (1920).

HolotyPe: WeStern AUSTRalia: Coolgardie Goldfield in open sandy places; Pritzel 844, (BM, n.v.). ISOTYPE: NSW.

Shrub 1 to more than $2 \mathrm{~m}$ tall with numerous slender erect branches and rather close firm bark; the younger stems silky-pubescent early but becoming glabrous, usually tuberculate, without an extended flange but with a groove from beside each node, the stem usually conspicuously extended below the node, the branching at c. $45^{\circ}\left(-30^{\circ}\right)$ but soon adjusting to become erect. Leaves erect, 5-12 mm long and 1-4 $\mathrm{mm}$ wide, usually very narrowly obovate, silky but glabrescent, flat or with the margins slightly incurved, and rather thick, especially near the apex, obtuse or occasionally acute, with a small apical point, tapering at the base, usually to a slender petiole. Flowers white, 6-10 $\mathrm{mm}$ in diameter, 1 or 2 together on short condensed shoots in adjacent leaf-axils or terminal on very short axillary branches with or without leaves, the new growth developing during flowering both relatively vigorously at the ends of branches and to a restricted extent on the lateral branches. Bracts few, broad red-brown and scarious; the bracteoles longer and more narrow; all usually readily deciduous but occasonally persisting around mature buds. Hypanthium silkypubescent, 3-4 $\mathrm{mm}$ long, gradually tapering from the rather expanded upper part to the somewhat fluted base, the top of the ovary silky. Sepals persistent, $1.5 \mathrm{~mm}$ long, long-deltoid, infolded near the apex and usually rather scarious and glabrous at least on the margins. Petals c. $3 \mathrm{~mm}$ long. Stamens in bundles of c. 5-7 or more, c. $1 \mathrm{~mm}$ long, the filaments not broad-based, the anther-cells c. $0.3 \mathrm{~mm}$ long, parallel, broad and shallow. Style well inset, not very stout; with a medium-sized stigma. Ovary 3-locular, each loculus with c. 20 ovules in 4 rows on a broad and relatively large placenta. Fruit not persisting, c. $3 \mathrm{~mm}$ in diameter, silky-pubescent, widest in the upper part, the upper part of the hypanthium forming an erect rim bearing the usually erect sepals, the lower part lobed in cross-section, and rounded above a slender stalk $1-3 \mathrm{~mm}$ long, the valves thin and exserted almost to the hypanthium-rim, or, especially after opening, beyond it. Mature seeds $1 \mathrm{~mm}$ long, obovoid-cuneiform, coarsely reticulate. Main flowering period: Sept.-Dec.

Distribution: From the Coolgardie district through eremaean regions of Western Australia to western South Australia (Map 5). The disjunction shown by present collections is likely to be negated by further collecting. On sandplain, in scrub or on rocky outcrops.

Selected SPECIMENS: SOUTH Australia: North-western: Wyola Lake, Weber 6535, 8.1980 (AD). WESTERN AUSTRALIA: Helms: 38 miles [60 km] E. of Neale Junction, Great Victoria Desert, George 8442, 10.1966 (PERTH). Austin: $26 \mathrm{~km} \mathrm{~S}$. of Menzies, Thompson 4617, 10.1987 (NSW, PERTH); Comet Vale, Gardner 7962, 10.1945, 11114, 11.1953 (PERTH). Coolgardie: inter Mt Jackson et lacum Deborah, Gardner 1911, 10.1966 (PERTH); $50 \mathrm{~km} \mathrm{W.} \mathrm{of} \mathrm{Coolgardie,} \mathrm{Thompson} \mathrm{4614,} 10.1987$ (NSW, PERTH).

Most authors have included this species in $L$. roei.

\section{L. blakelyi $J$. Thompson sp. nov.}

Frutex c. $1 \mathrm{~m}$ altus. Folia obovata ad late elliptica, 4-8 $\mathrm{mm}$ longa. Flores c. 7 $\mathrm{mm}$ diametro, sepalis persistentibus, hypanthio et pedicello longiattenuato. Ovarium 3-5-loculare. Fructus 2-3.5 mm diametro tarde decidui.

HolotyPE: NeW SOUTH WaLES: on ridge overlooking the Upper Dam, Lithgow W[ater] S[upply], Clarence, W.F. Blakely, Jean and W.J. Buckingham NSW 154743, 25.11.1939 (NSW). 
Broadly spreading shrub c. $1 \mathrm{~m}$ tall with bark, as seen on specimens of closely adhering flakes, shed in slender fibre-like strips; the younger stems slender, densely silky-pubescent at least at first, lacking a flange but broad around and below the petiole base, with branching at c. $60^{\circ}$. Leaves diverging and recurving especially near the apex, mostly $4-8 \mathrm{~mm}$ long and $2-5 \mathrm{~mm}$ broad, obovate to very broadly elliptical, often concave, both surfaces usually glabrous except for silky hairs on the base and margins, the apex (variable within the specimen) broadly rounded to acute or acuminate, and blunt to with a short, stout, rather pungent point, the base tapering gradually or more abruptly to a short, distinct, rather slender petiole often broader at the extreme base. Flowers white or pink, c. $7 \mathrm{~mm}$ in diameter, $1-4$ on modified shoots, occasionally axillary but usually at the ends of short few-leaved branches in adjacent axils, with the terminal bud of the flowering shoot very precocious, elongating, vigorously near the ends of the branches before the flower buds open, leaving buds as monads in bractaxils and with a few bract-scars at the base. Bracts few, broad, red-brown and firmly scarious, the inner longer and the bracteoles much longer, all shed very early. Hypanthium very slender, usually densely silky hairy and vertically ridged, often c. $2 \mathrm{~mm}$ long, the upper part somewhat expanded, tapering below and then more abruptly to a long, tapering, very slender pedicel often $5 \mathrm{~mm}$ or more in length, the top of the ovary silky. Sepals persistent, c. $1-1.5 \mathrm{~mm}$ long, deltoid, somewhat longer than broad, and rather keeled and hooded, somewhat thinner in texture than the hypanthium and often less pubescent though sometimes with the margins ciliate. Petals $2-2.5 \mathrm{~mm}$ long. Stamens in bundles of $3-5,1 \mathrm{~mm}$ or less in length, the filaments little broader in the lower part, the anther-cells c. $0.3 \mathrm{~mm}$ long, parallel, broad and shallow. Style shallowly inset and tapering to a small stigma. Ovary 3-5-locular, each loculus with c. 6-8 pendulous ovules in 2 rows on a high, large but rather shallow, placenta. Fruit tardily deciduous, $2-3.5 \mathrm{~mm}$ in diameter, glabrescent, widest at the usually erect hypanthium-rim bearing erect or spreading sepals, rather lobed in crosssection and tapering to, or somewhat rounded above, a long filiform stalk to 7 $\mathrm{mm}$ or more in length, the valves thin, not much, if at all, exserted beyond the hypanthium-rim after opening. Mature seeds not seen, probably obovoidcuneiform, the surface of young seeds reticulate. Main flowering period: Nov.Dec.

DISTRIBUTION: Limited to sandstone escarpments above the town of Lithgow on the Central Tablelands of New South Wales (Map 5). In very shallow soil.

SELECTED SPECIMENS: NEW South WaLES: Central Tablelands: Lithgow Water Supply, Lithgow side, Blakely \& Buckingham NSW 154744, 12.1938 (NSW); Hassans Walls Lookout, Briggs 6974, 10.1978 (NSW), Thompson 4207, 11.1981 (NSW), Burgess NSW $154745,10.1961$ (NSW).

This species is named for W. F. Blakely, formerly a botanist at NSW, who prepared an unpublished manuscript description recognising this species.

31. L. microcarpum Cheel, J. \& Proc. Roy. Soc. New South Wales 57: 126 (1923).

LectotyPe, here chosen: New South Wales: Copmanhurst, E. Cheel NSW 154747, 11.1917 (NSW).

Shrub 1-2 $\mathrm{m}$ or more in height with bark seen on specimens as close and shedding fibres but variously described in notes as smooth, flaking to become smooth and peeling in strips; the younger stems glabrous or with appressed fine hairs, rarely with minute hairs, and the flange a conspicuous ridge from beside 
each node with the stem extended immediately below the leaf-base, the branching at c. $45^{\circ}$. Leaves divergent with those on new lateral growth crowded, often recurved, later spreading or even reflexed, from a few $\mathrm{mm}$ to $20 \mathrm{~mm}$ long and to $4 \mathrm{~mm}$ wide and often very variable on one plant, elliptical to narrowly oblanceolate, usually rather thick and with the margins or the whole surface incurved, glabrous at maturity except for a few hairs on the base of the upper surface, the apex obtuse to long-acuminate, incurved or infolded and usually with a conspicuous pungent point to $1 \mathrm{~mm}$ long, the base narrowing to a conspicuous slender petiole expanded at the extreme base. Flowers white, c. 8-12 mm in diameter, occurring singly or 2 together, on short modified shoots, occasionally axillary, usually at the ends of short (leafless or) few-leaved branches in adjacent leaf-axils and at the ends of longer, and older, leafy branches, the new growth developing mostly at branch-ends during flowering. Bracts few or more numerous, broad and red-brown, with the bracteoles thinner, longer and more narrow-based, most shed before the flower opens. Hypanthium densely covered with silky spreading or appressed hairs, usually 2-3 $\mathrm{mm}$ long, the upper part spreading, the lower 0.5 to $1.5 \mathrm{~mm}$ rather abruptly contracted to a tapering pedicel, the top of the ovary with a short silky pubescence dense near the style-base. Sepals persistent, 1-1.2 $\mathrm{mm}$ long, shortoblong to hemispherical, obtuse, like the hypanthium in the centre but with broad, pale, thin margins usually ciliate at the edge. Petals c. 3-5 mm long. Stamens in bundles of 3-5, 1-1.5 mm long, with some filaments rather broad in the lower part, the anther-cells $0.4-0.5 \mathrm{~mm}$ long, parallel, broad and shallow. Style variably, but not deeply, inset, and rather straight above a broad base, with a medium-sized stigma. Ovary (3-)4(-5)-locular, each loculus with c. 20-40 ovules in c. 4 rows on a rather large and high placenta. Fruit deciduous but often some persisting until the next flowering, 3-4 $\mathrm{mm}$ in diameter, pubescent, widest in the upper part with the erect persistent sepals on a rather erect or incurved hypanthium-rim, the part about the ovary much shorter than broad, lobed in cross section and abruptly contracting to an almost inset slender stalk $1-1.5 \mathrm{~mm}$ long, the valves thin, raised, especially near the style (though still rounded), above the hypanthium-rim but usually below the tips of the sepals. Mature seeds c. $1 \mathrm{~mm}$ long, obovoid-cuneiform, very dark, with a narrow-reticulate pattern and a few loose cells. Main flowering period: Mostly Aug.-Oct.

Distribution: From the Wide Bay district of Queensland to northeastern New South Wales (Map 5). On mountains and escarpments of volcanic, granite and sandstone rock, usually in shallow soil on rock ledges or cliff-faces.

Selected SPECIMENS: QueEnSLAND: Wide Bay: Mt Cooroora, White 18927, 3.1923 (BRI, CANB, NSW). Moreton District: Mt Tibrogargan, W. of Beerburrum, Coveny $6719 \&$ Hind, 8.1975 (NSW). Darling Downs: Jollys Falls, 2 miles [3.2 km] W. of the summit, Fisher 282, 10.1970 (CANB, NSW). New South Wales: North Coast: summit, Mt Warning, Rodway 2968, 10.1939 (NSW); North Rocks Road, Nightcap Range ... c. 15 $\mathrm{km}$ W. of Mullumbimby, Coveny 9909 \& Haegi, 10.1977 (NSW). Northern Tablelands: E. of Torrington, Wissman NSW 154748, 10.1975 (NSW). North Western Slopes: Ashford area, Fox NSW 154750, 9.1963 (NSW).

On the granite of northern New South Wales and southern Queensland this species grows with and resembles $L$. brevipes. However, it remains distinguishable particularly in regard to the condensation of its lateral shoots, its green coloration and the tendency for its bark to flake. It is possible that a few herbarium specimens from this region showing long narrow fruit-bases indicate hybridisation with $L$. brevipes. 


\section{L. polyanthum $J$. Thompson sp. nov.}

Frutex vel arbor usque ad $5 \mathrm{~m}$ alta. Folia elliptica, 1-2.5 $\mathrm{cm}$ longa. Flores 5-6 $\mathrm{mm}$ diametro, in nodis adjacentibus numerosis in extremitatibus ramulorum, sepalis glabratis persistentibus. Ovarium c. 5-loculare. Fructus c. $3 \mathrm{~mm}$ diametro decidui.

Holotype: New South Wales: Nepean Dam, Bargo, 1250' [380 m], E.F. Constable NSW 129836, 1 Dec. 1953 (NSW).

Spreading shrub or small tree to $5 \mathrm{~m}$ tall, often of pendulous habit, with firm furrowed, ultimately somewhat flaking, bark; the younger branches very slender with a silky pubescence and also usually with areas of short erect or even antrose hairs, the pubescence tending to persist, with the flange represented by grooves beside each node and the stem not or scarcely expanded below, and with the branching at c. $45^{\circ}$. Leaves diverging, often widely, $10-25 \mathrm{~mm}$ long and 2-4 mm wide, elliptical or occasionally wider above or below the middle, flat or almost so and glabrous at maturity, rather thick in drier regions but often thin, the apex obtuse or tapering, with a blunt point, the base tapering, to the same extent as the apex, to a slender petiole. Flowers white, 5-6(-10) $\mathrm{mm}$ in diameter, occurring singly or occasionally $2(-3)$ together on short modified shoots usually in a long series of adjacent leaf-axils on leafless nodes, the new growth very vigorous at the ends of branches, usually after flowering, with little if any development from the flowering region. Bracts not very numerous, broad and red-brown; the bracteoles longer; all rarely seen, shed from the young bud leaving big scars. Hypanthium usually glabrous, occasionally with some hairs at the base, and rather dark and turgid, c. $2 \mathrm{~mm}$ long, the upper part spreading widely, the lower tapering but rather abruptly rounded above a short pedicel c. $1 \mathrm{~mm}$ long, the top of the ovary with a close silky pubescence. Sepals persistent, c. $0.7 \mathrm{~mm}$ long, obtusely ovate with incurved margins and hooded, glabrous, similar in texture to the hypanthium, well spaced and often with a small groove at the base. Petals c. $3 \mathrm{~mm}$ long. Stamens in bundles of 3-5, 1-1.5 mm long, with some filaments broad in the lower part, sometimes with a few silky hairs, the anther-cells $0.4-0.5 \mathrm{~mm}$ long, shallow after opening and parallel but tending to both recurve and fold back. Style inset, broad-based and tapering, with a rather small stigma; often modified or absent. Ovary (3-)5(-6)-locular, each loculus with c. 18 pendulous ovules in 4 rows on a large, high placenta; occasionally absent. Fruit very readily shed but some usually persisting until the next flowering, usually c. $3 \mathrm{~mm}$ in diameter, glabrous and rather glossy, widest near the erect or somewhat incurved hypanthium*-rim, lobed in crosssection and rounded above a tapered narrow stalk c. $1 \mathrm{~mm}$ long, the valves thin, raised, rounded, even at opening beyond the rim but usually below the erect or incurved sepals. Mature seeds c. $1 \mathrm{~mm}$ long, obovoid, very dark and closely and coarsely reticulate with lines of loose cells. Main flowering period: Oct.-Jan.

DistRIBUTION: From the Armidale district and Warrumbungle Mountains of New South Wales, through coastal and tableland areas as far south as Wombeyan Caves (Map 5). In rocky situations on escarpments or on stream banks in rocky gullies.

Selected specimens: New South Wales: North Coast: Dibbs Head, Dorrigo National Park, Floyd 969, 5.1978 (NSW). Central Coast: banks of the river Hawkesbury, Brown, 1.1805 (MEL, NSW). Northern Tablelands: $20 \mathrm{~km}$ ENE. of Hillgrove, Williams, 1.1976 (NE, NSW). Central Tablelands: Wentworth Falls, Jacobs NSW 154749, 3.1936 (NSW). North Western Slopes: The Spire, Warrumbungle Mts, Constable NSW 129837, 5.1948 (NSW). Central Western Slopes: N. slope of Burning Mtn, $3 \mathrm{~km}$ NNE. of Wingen, Pickard \& Coveny 1076, 6.1969 (NSW). 
This species is named for the large number of flowers produced on each stem of the flowering region.

\section{L. brevipes F. Muell., Trans. Philos. Soc. Victoria 1: 125 (1855).}

LECTOTYPE, here chosen: Buffalo Creek, F. Mueller, 6 March [18]53, MEL 1539307. ISOLECTOTYPES: MEL 1512928, K (n.v., photo NSW).

Spreading shrub or small tree to $4 \mathrm{~m}$ or more in height with close bark, firm and dark on mature trunks; the younger stems very slender, with appressed fine persistent hairs, with the flange represented only by grooves beside each node and the stem not or scarcely expanded below, and with the branching $\mathrm{c}$. $30^{\circ}-40^{\circ}$. Leaves diverging and sometimes later spreading, 10- >20 $\mathrm{mm}$ long and usually more than $5 \mathrm{~mm}$ broad, elliptical to narrowly oblanceolate or obovate, often rather thick in texture (? in drier situations), the apex obtuse or shortly acuminate, usually somewhat recurved with a minute pungent point, the base narrowing to a short petiole; flat or with the margins somewhat recurved, with an appressed silky pubescence or glabrous at maturity. Flowers white, $6-8 \mathrm{~mm}$ in diameter, occurring singly or 2 together on short modified shoots in leaf-axils, usually in a long series of adjacent axils, the new growth very vigorous at the ends of branches, usually during flowering, with little, if any, development from the flowering region. Bracts not numerous and not very broad; the bracteoles narrow-lanceolate; all shed from the very young bud. Hypanthium with a spreading or appressed silky pubescence, usually $2-3 \mathrm{~mm}$ long, the upper part not much expanded, the lower tapering rather abruptly to a pedicel whose length tends to vary from short to very long $(2->5 \mathrm{~mm})$ according to the population, the top of the ovary with a dense short silky pubescence. Sepals persistent, 1-1.5 mm long, obtusely deltoid, silky-pubescent but the tips sometimes almost glabrous and somewhat hooded; rather widely spaced. Petals c. $3 \mathrm{~mm}$ long. Stamens in bundles of 3-5, c. $1 \mathrm{~mm}$ long, the filaments somewhat broader in the lower part, the anther-cells c. $0.4 \mathrm{~mm}$ long, shallow and parallel but folded back. Style inset, not very broad-based, and with a large (relative to the style) stigma. Ovary (3-)5-locular, each loculus with c. (10-) 20 ovules in (2-) 4 rows on a large, high placenta. Fruit deciduous, usually 3-4 $\mathrm{mm}$ in diameter and pubescent, the upper part of the hypanthium forming a wide erect rim bearing erect calyx-lobes, the lower part lobed in cross-section and rounded above a slender tapering stalk occasionally only c. 2 but usually several (up to 8) $\mathrm{mm}$ long, the valves thin, rounded and raised above the erect rim but rarely reaching the top of the erect sepals. Mature seeds c. $1.25 \mathrm{~mm}$ long, obovoid-cuneiform, with a coarse reticulate pattern and conspicuous rows of loose cells. Main flowering period: Oct.-Dec.

Distribution: Common in the Granite Belt of southern Queensland and through the North Western Slopes, Northern Tablelands and lower North Coastal mountains of New South Wales; rare on the Central Tablelands, but again common on the Southern Tablelands and South Coast and in northeastern Victoria (Map 5). On rock outcrops and rocky hillsides; especially on granite but on serpentines on the North Coast of New South Wales.

Selected SPECimens: QueEnSLAND: Darling Downs: $16 \mathrm{~km}$ WSW. of Stanthorpe, Pedley $4140,9.1973$ (NSW). NEw SouTH WALES: North Coast: Ellenborough Falls, $2 \mathrm{~km} \mathrm{~N}$. of Elands, Coveny 9884 \& Haegi, 11.1977 (NSW). South Coast: Moruya, Boorman NSW 129838, 11.1911 (NSW). Northern Tablelands: Dandahra Creek, c. 42 1/2 miles [68 km] ENE. of Glen Innes ..., Tindale NSW 84081, 12.1966 (NSW). Central Tablelands: Gulf Stream, Winburndale Nature Reserve, Coveny 9636, 10.1977 (NSW). Southern Table- 
lands: Lobbs Hole, 12 miles [19 km] NW. of Kiandra, Phillips CBG 006281, 11.1961 (NSW). North Western Slopes: Howell, Jackson 2258, 10.1972 (AD, NSW). VICTORIA: North-eastern Highlands: between Mt Beauty \& Falls Creek, Clover Dam area, Beauglehole 22418, 1.1967 (MEL, NSW). East Gippsland: \pm 3 miles [5 km] direct NE. of Bemm River Post Office, Beauglehole 34395, 10.1970 (MEL, NSW).

This species is very variable, but associated morphological differences tend to indicate regional forms. On available collections, subdivision of the taxon does not appear to be possible. In the Stanthorpe district (Queensland) L. brevipes grows with $L$. microcarpum and some specimens from this area may represent hybrids between these species. The aspect of these specimens differs from that of the form of $L$. brevipes found in this region.

34. L. sericatum Lindley in Mitchell, J. Exped. Trop. Australia: 289 (1848).

Holotype: QueEnSLAND: near the Pyramids [Mt Playfair district], $T$. Mitchell, 5th Sept. 1846 (n.v.). TOPOTYPE: Mitchell 380, Oct. 9th 1846 (BM, n.v., photo BRI, NSW).

SYNONYMY: L. stellatum forma sericatum (Lindley) Domin, Biblioth. Bot. 89:454 (1928).

Erect shrub 2-3 $\mathrm{m}$ tall, rather grey-green in aspect and with dense foliage, the bark, as seen on specimens, close and firm; the younger stems usually thin with a long, silky, mostly appressed, sometimes spreading, pubescence, with the flange represented only by grooves from the side of each node and the stem usually not or scarcely extended below, and with the branching frequent and at $45^{\circ}-60^{\circ}$. Leaves divergent or occasionally spreading, most 5-10 mm long and 1.5-3 mm wide, very narrowly obovate to elliptical, flat or almost so, with a very fine mostly appressed pubescence on both surfaces, rather firm in texture, the apex rounded to broadly acute and usually with a short, broad, blunt point, the base long-tapering to a short petiole. Flowers white or pink, c. $10 \mathrm{~mm}$ in diameter, occurring, usually singly, on short modified shoots, some axillary but most at the ends of short few-leaved axillary branches, the new growth apparently always rather limited. Bracts few, broad, red-brown and quite thin; the bracteoles similar but larger; at least some tending to persist until the flower opens. Hypanthium silky-pubescent, c. $2 \mathrm{~mm}$ long, tapering, more suddenly near the base, to a fluted pedicel section, the top of the ovary silky. Sepals persistent, 1-1.5 mm long, obtusely ovate-deltoid, thin, pale and sparsely silky with ciliate margins, rather keeled with the apex distinctly hooded and keeled. Petals 3-4 mm long. Stamens in bundles of c. 5, c. $1 \mathrm{~mm}$ long, the filaments somewhat broader in the lower part, the anther-cells c. $0.3 \mathrm{~mm}$ long, parallel, broad and shallow. Style inset, broad-based, with a large (relative to the style) stigma. Ovary (? always) 5-locular, each loculus with c. 20 ovules in 4 rows on a high, rather narrow but not small placenta. Fruit deciduous, not seen. Seeds not seen. Main flowering period: Sept.-Oct.

DiSTRIBUTION: In the Leichhardt District of Queensland (Map 5). Usually in crevices in sandstone escarpments.

SELECTED SPECIMENS: QueENSLAND: Leichhardt: Blackdown Tableland, c. $35 \mathrm{~km}$ SE. of Blackwater, Henderson 1067 et al., 9.1971 (BRI, NSW); ridge N. of Arch Creek, "Early Storms", Carnarvon Creek, Gittins 2773, 9.1974 (NSW); Isla Gorge about 18 miles [29 km] SW. of Theodore, Everist 8029, 9.1968 (BRI, NSW).

\section{L. neglectum $J$. Thompson sp. nov.}

Frutex usque ad $2 \mathrm{~m}$ altus. Folia elliptica, 1-2 cm longa. Flores $8-11 \mathrm{~mm}$ diametro, sepalis pallidis sericeis persistentibus. Ovarium 3-5-loculare. Fructus 3-4 $\mathrm{mm}$ diametro decidui. 
Holotype: QueEnSLAND: $17 \mathrm{~km}$ W. of Paluma, E.M. Jackes \& B.R. Jackes, 9.9 .1982 (NSW 154751).

SYNONYMY: L. attenuatum var. subsessile C.T. White, Proc. Roy. Soc. Queensland 50: 76 (1939). LECTOTYPE, here chosen: QUEENSLAND: Traverston [Traviston], C.T. White 6353 (fl.), 6.10 .1929 (NSW). ISOLECTOTYPE: BRI.

Erect shrub to $2 \mathrm{~m}$ tall, rarely a tree of almost $10 \mathrm{~m}$, with bark close and fibrous; the younger stems often slender, silky-pubescent at least at first, with the flange represented only by grooves from beside each node with the stem not or scarcely enlarged below, and with branching at $30^{\circ}\left(-45^{\circ}\right)$. Leaves diverging but not spreading widely, 10-20 mm long and 2-3 mm wide, elliptical, flat and usually rather firm, and silky-pubescent, becoming more glabrous but often with some hairs remaining on the margins, the apex obtuse to acute with a very short point, the base long-tapering to a short petiole. Flowers white, $8-11 \mathrm{~mm}$ in diameter, occurring singly or, rarely, 2-together on short modified leafless shoots, in adjoining axils and terminating short leafy side-branches, the new growth usually rather limited, somewhat more vigorous at branch-ends. Bracts few, red-brown and firm; the bracteoles larger; all well-developed but shed before the flower opens. Hypanthium densely silky-pubescent, c. $3 \mathrm{~mm}$ long, broad above and tapering, and abruptly contracting to a short pedicel, the top of the ovary silky. Sepals persistent, c. $1 \mathrm{~mm}$ long, ovate-oblong, pale, especially at the margin and rounded apex, usually silky at least in the centre and on the margins. Petals c. $4 \mathrm{~mm}$ long. Stamens in bundles of c. $5,1 \mathrm{~mm}$ or less in length, the slender filaments somewhat broader in the lower part, the anthercells c. $0.4-0.5 \mathrm{~mm}$ long, parallel, broad and shallow but folded back. Style a little inset, rather stout and straight, with a medium-sized stigma. Ovary 3-5locular, each loculus with c. 15 ovules in 4 rows on a very high relatively large placenta. Fruit deciduous, 3-4 $\mathrm{mm}$ in diameter, rather silky and lobed in cross-section, widest where the upper part of the hypanthium forms an erect or incurved rim bearing erect or incurved sepals, the part about the ovary much wider than deep, usually contracted abruptly to a short, c. $1 \mathrm{~mm}$ or less, stalk, the valves very thin, raised high above the erect hypanthium-rim even before opening, and reaching the top of the sepals. Mature seeds c. $1.5 \mathrm{~mm}$ long, irregularly and rather narrowly obovate-oblong, finely and narrowly reticulate with occasional loose cells. Main flowering period: Oct. or earlier.

DisTRIBUTION: On the coast and eastern ranges of Queensland from Herberton to the Bundaberg district (Map 5). In sandy soil in rocky places.

SELECTED SPECIMENS: QUEENSLAND: North Kennedy: ... W. of the road from Ravenshoe to Koombooloomba Dam, Clarkson 2673, 10.1979 (BRI, NSW). Port Curtis: Shoalwater Bay, strait S. of Townshend Is., [and] Port Clinton Port 2, Brown, 8.1802 (BRI, MEL, NSW); c. $22 \mathrm{~km}$ from Agnes Water, S. of Gladstone, Stanley 78185 \& Ross, 11.1978 (BRI). Burnett: ... Biggenden Bluff, White 7318, 10.1930 (BRI, NSW). Wide Bay: Burrum Heads, Watson Q.F.D. 62/259, 11.1961 (BRI).

This species is named for the lost opportunities associated with it. Brown's specimens show two manuscript names. E. Cheel corresponded with C.T. White about it under yet another name.

\section{L. lamellatum $J$. Thompson sp. nov.}

Frutex vel arbor usque ad $5 \mathrm{~m}$ vel altiora cortice lamellato. Folia elliptica plus minusve falcata, $1-2 \mathrm{~cm}$ longa. Flores $5-13 \mathrm{~mm}$ diametro, sepalis glabratis vel pubescentibus persistentibus. Ovarium 3-5-loculare. Fructus 2-4 mm diametro decidui. 
Holotype: QuEENSLAND: 21 miles [34 km] S.E. of Bedourie Homestead, Leichhardt District, N.H. Speck 1843, 14.x.1963 (NSW). IsOTYPES: BRI, CANB.

Shrub c. $3 \mathrm{~m}$ tall or slender tree of more than $5 \mathrm{~m}$ with the bark of main stems in many, often reddish, papery layers; the younger stems very slender and silky-pubescent, later with the pubescence decreasing and irregular, without a flange and not or scarcely widening at each node, the branching at $30^{\circ}-45^{\circ}$. Leaves diverging, $10-40 \mathrm{~mm}$ long and $1.5-4 \mathrm{~mm}$ wide, narrowly elliptical and often somewhat falcate, flat, often grey-green owing to a dense silky pubescence, sometimes later green but usually with some hairs remaining, the apex usually tapering to a short or long, often pungent, point, the base tapering and not or scarcely petiolate. Flowers white, $5-13 \mathrm{~mm}$ in diameter, occurring singly or 2 together on short modified shoots in adjacent axils (on adjoining branches), with new growth extending vigorously at branch-ends during and after flowering. Bracts few, firm, broad and red-brown; the bracteoles longer and more scarious; all shed from the young bud but leaving prominent scars. Hypanthium longitudinally ridged with a close, short pubescence, or glabrous, c. $2 \mathrm{~mm}$ long, much expanded in the upper part, tapering and then more abruptly to a rather fluted, tapering pedicel usually $3-5 \mathrm{~mm}$ long, the top of the ovary densely pubescent. Sepals persistent, c. $1 \mathrm{~mm}$ long, obtusely broadly ovate, somewhat keeled and hooded, with wide scarious margins but otherwise like the hypanthium, glabrous or somewhat short-pubescent. Petals $3-5 \mathrm{~mm}$ long. Stamens in bundles of 3-7, 0.5-1.5 mm long, the filaments often somewhat broad in the lower part, the anther-cells c. $0.4-0.5 \mathrm{~mm}$ long, parallel, broad and shallow but folded back. Style inset, rather stout, with a small stigma. Ovary 3-5-locular, each loculus with c. 12 ovules in 4 rows on a very high, relatively large, placenta. Fruit deciduous, usually $2-4 \mathrm{~mm}$ in diameter, the upper part of the hypanthium erect forming a wider rim, the part around the ovary narrower and lobed in cross-section, often somewhat tapering but usually, at the base, rounded above a rather stout, also tapering, stalk $2 \mathrm{~mm}$ or more in length, the valves, even before opening, conspicuously exserted, to the level of the persistent, erect, hooded sepals or beyond, so that the broad part of the fruit often appears almost spherical. Mature seeds $2-2.5 \mathrm{~mm}$ long, narrowly obovoid-cuneiform, shallowly reticulate with rows of loose cells. Main flowering period: Aug.-Nov.

DISTRIBUTION: Common in the Leichhardt District and scattered in other parts of inland Queensland (Map 5). In sandy soil in woodland or among rocks, often of watercourses, associated with ridges, especially of sandstone.

SELECTED SPECIMEN: QUEENSLAND: Leichhardt: Salvator Rosa National Park, near Nogoa R., Blaxell 1495 and Armstrong, 8.1977 (NSW). Mitchell: Enniskillen, White 12380, 11.1943 (BRI). South Kennedy: 8 miles [13 km] E. of "Clydevale" Station, Adams 1272, 8.1964 (BRI, CANB, NSW). Maranoa: $14 \mathrm{~km} \mathrm{~N}$. of Ogilvie road junction on "Mt Moffat" road, Wilson 3440, 4.1981 (NSW). Burnett: Eidsvold, Bancroft, 12.1924 (BRI, NSW). Wide Bay: Maryborough District, Young, 2.1917 (NSW).

This species is named for the unusual bark commented upon by most collectors and included in the specimen by many.

37. L. multicaule A. Cunn. in Field, Geog. Mem. New South Wales: 349 (1825).

Holotype: New South Wales: barren, brushy hills near Bathurst, A. Cunningham 127 (K, n.v., photo NSW).

Erect to almost prostrate shrub less than $2 \mathrm{~m}$ in height and often forming dense thickets, the bark, as seen on specimens, close and tending to shed loose fibres; 
the younger stems slender and usually with a dense silky pubescence, rarely glabrous, without a flange but sometimes with a short extension below each node, and often with branching at $30^{\circ}$ or less but frequently with the branches adjusting later to a wider angle. Leaves erect at first but later spreading, very variable, 2-10 $\mathrm{mm}$ long and $1-3 \mathrm{~mm}$ wide, usually narrowly to broadly elliptical or broader towards the apex, flat or tending to be concave, rarely slightly convex, usually at least in part with an appressed silky pubescence especially on the lower surface, the apex shortly acute to acuminate, rarely obtuse, with a short point tending to recurve, the base tapering to a very short broad petiole. Flowers pink or white, $6-10 \mathrm{~mm}$ in diameter, singly or occasionally 2 together on short modified shoots that are axillary in adjoining axils and at the ends of short few-leaved axillary branches, the new growth rather irregular but usually vigorous at branch ends. Bracts few, broad and red-brown, rather scarious, the inner and bracteoles large, the latter a little narrower, but shed before the flange opens. Hypanthium with appressed silky hairs occasionally the pubescence absent from the upper part or the whole, c. $2.5 \mathrm{~mm}$ long, the upper part spreading, the lower tapering and rather fluted above a very short, $<1 \mathrm{~mm}$, pedicel, the top of the ovary silky-pubescent. Sepals persistent, c. $1-1.5 \mathrm{~mm}$ long, shortly deltoid to oblong, broadly obtuse but often appearing acute because keeled and rather hooded behind the apex, the whole or at least the margins thin and pale, glabrous or pubescent especially near the centre, the margins usually with some cilia. Petals c. $2.5 \mathrm{~mm}$ long. Stamens in bundles of $3-5$, c. $1.5 \mathrm{~mm}$ or less in length, with some filaments very broad in the lower part, the anther- cells c. $0.3-0.4 \mathrm{~mm}$ long, parallel, broad and shallow, with some folded back. Style scarcely inset, somewhat broad-based with a small stigma. Ovary 3 (-4)-locular, each loculus with up to c. 10 ovules in (2-)4 rows on a very high short, broad and rather shallow placenta. Fruit deciduous, c. 3.5 $\mathrm{mm}$ in diameter, rather silky, widest where the erect upper part of the hypanthium forms a conspicuous rim bearing erect hooded sepals, the part about the ovary conspicuously lobed in cross-section and contracting suddenly to an almost inset short stalk, the valves thin, much exserted even before opening and often extending to or beyond the tips of the large sepals. Mature seeds few, c. $2 \mathrm{~mm}$ long, obovoid-cuneiform, very dark with a very coarse almost foveate-reticulate surface. Main flowering period: Oct.-Nov.

Distribution: Widespread on the Central and Southern Tablelands of New South Wales and in adjoining parts of the Western Slopes and Victoria (Map 5). In woodlands and on dry hillsides.

SElECted SPECIMENS: New South WaLEs: Central Tablelands: Hill End, Cambage 2679, 7.1911 (NSW). Southern Tablelands: SE. foot of Black Mtn, Canberra, A.C.T., Darbyshire 1249, 10.1963 (CANB, NSW); North Queanbeyan, Cambage 3370, 12.1911 (NSW). Central Western Slopes: Bowen Park, Blakely NSW 61319, 10.1906 (NSW). South Western Slopes: 4 miles [6.4 km] SSW. of Carabost, NE. of Holbrook, Logan NSW 84022, 11.1966 (NSW). VICTORIA: Northeastern Highlands: Mitta Mitta, Clinton $1651,2.1918$ (NSW).

38. L. divaricatum Schauer in Walp. Rep., Suppl. 1: 923 (1842).

Holotype: New South Wales: in Nov. Camb. austr. interioris [Lachlan R.], $A$. Cunningham 196 (?, n.v.). ISOTYPE: K, n.v., photo NSW.

Synonymy: L. trivalve Cheel, J. \& Proc. Roy. Soc. New South Wales 65: 201 (1932), as L. trivalvum. LeCTOTYPE, here chosen: NEW SOUTH WALES: Dubbo to Tomingley, J.H. Maiden, September, 1898 (NSW). 
Several-stemmed, erect or rather weeping shrub $1-4 \mathrm{~m}$ tall with compact and fibrous bark; the younger stems slender and pubescent with long appressed or, more frequently, curled or irregular hairs, without a flange but extended just below each node, the branching spaced and usually at an angle of c. $45^{\circ}$ though often curving to make this appear smaller. Leaves divergent to spreading widely, 2-7 (-10) $\mathrm{mm}$ long and $1-2(-3) \mathrm{mm}$ wide, broadly to narrowly elliptical or obovate, concave or infolded but recurving from the stem, with at least some appressed or spreading silky hairs and often, especially at the base of the upper surface, some curled hairs, the apex acute with a pungent, often slightly incurved, point, the base tapering to a short broad petiole. Flowers white, 6-10 $\mathrm{mm}$ in diameter, single, or, rarely, 2 together, on short modified axillary shoots at the ends of short crowded few-leaved shoots on crowded branches, the new growth developing at branch-ends after flowering. Bracts few, broad and dark red-brown, the inner and bracteoles much longer and larger, enveloping the bud but shed before it opens. Hypanthium with long fine spreading hairs, often more sparse on, or even absent from, the upper part, c. $2 \mathrm{~mm}$ long, the upper part spreading widely, the lower tapering and somewhat fluted and narrowing rather gradually to a tapered pedicel $0.5-1.5 \mathrm{~mm}$ long, the top of the ovary with a rather silky pubescence at least around the base of the style. Sepals persistent, 1-1.2 mm long, a little keeled near the tip, somewhat acute, usually deltoid, with spreading hairs at least in the centre, the margins scarious, glabrous or rarely ciliate. Petals $2.5-3.5 \mathrm{~mm}$ long. Stamens in bundles of 3-5, c. $1.2 \mathrm{~mm}$ long, with some filaments broad in the lower part, the anther-cells c. $0.4 \mathrm{~mm}$ long, parallel, broad and shallow. Style often scarcely inset, narrow with a small stigma. Ovary (2-) 3 (-4)-locular, each loculus with c. 12-20 ovules in 4 rows on a high, broad, small and shallow placenta. Fruit deciduous, c. $4 \mathrm{~mm}$ in diameter, with long spreading hairs, widest at the erect rim-like upper part of the hypanthium bearing erect or spreading sepals (often with inrolled or incurved margins), the part about the ovary conspicuously lobed in crosssection and rounded above an inset stalk up to $2 \mathrm{~mm}$ long, the valves thin, much exserted even before opening and often extending almost to the tips of the large sepals. Mature seeds few, c. $2.2 \mathrm{~mm}$ long, oblong, very dark with a very coarse almost foveate-reticulate surface. Main flowering period: Aug.-Oct.

Distribution: On the Central Western Slopes of New South Wales and nearby on the North Western Slopes, and on the Western Plains southward from Nymagee (Map 5). Usually in sclerophyll woodland or heath, on dry hillsides or in mallee.

Selected SPECimens: New South Wales: North Western Slopes: Warrumbungle Ranges, Forsyth NSW 28562, 10.1901 (NSW). Central Western Slopes: c. $8 \mathrm{~km} \mathrm{~N}$. of Tomingley on Narromine road, Moore 6792, 9.1974 (CANB, NSW); $14 \mathrm{~km} \mathrm{NE}$. of Alectown on Baldry road via Gingham Gap, Coveny 10283, 10.1978 (NSW). South Western Plains: Marobee, E. C. Repeater Station, c. $60 \mathrm{~km}$ S. of Nymagee, de Nardi 609 , 9.1971 (NSW); summit of Mt Binya, Cocopara Range, Willis MEL 503328, 9.1969 (NSW). 


\section{Specific Descriptions - Group 2.}

L. petersonii subgroup (spp. 39-44), Map 6.

39. L. emarginatum Wendl. f. ex Link, Enum. Hort. Berol. Alt. 2: 25 (1822).

HOLOTYPE: Hab. in Australia (? B, n.v.). IsOTYPE: NSW.

Synonymy: Leptospermum odoratum Cheel, J. \& Proc. Roy. Soc. New South Wales 53: 122 (1919). LeCTOTYPE, here chosen: NEW SOUTH WaLES: Robt. Brown. Iter Australiense 1802-1805 (NSW, ex E). Specimens labelled Sydney (Port Jackson), banks of the River Grose, Robert Brown, December 1804 (NSW ex BM (2 sheets), MEL), are probably duplicates.

Shrub to $4 \mathrm{~m}$ in height with rough rather irregular bark; the younger stems only briefly silky-pubescent, soon glabrous, with a wide flange, especially just below the node, carried above the side of the leaf-base, and with branching often at $30^{\circ}$ or less. Leaves aromatic, divergent or later more spreading, (10-) 20-30 $(-35) \mathrm{mm}$ long and usually $2.5-7 \mathrm{~mm}$ wide, oblanceolate, narrowly obovate or elliptical, usually flat but often with a twist at the base, glabrous or with some hairs at the retuse apex, on the margins and/or at the base, long-tapering to a rather broad base. Flowers white, c. $7 \mathrm{~mm}$ in diameter, up to 5, on modified shoots, often in adjacent axils, and at the ends of short few-leaved branches in adjacent axils, usually with the terminal bud showing little or no development and with vigorous growth beyond, from branch-ends at flowering time, the new growth often reddish. Bracts broad and red-brown; the bracteoles longer than broad with dense fine hairs at the margins and the tip; all so soon shed as to be rarely seen. Hypanthium glabrous and dark-coloured with conspicuous glands, often 2-3 mm long, the upper part much expanded, all gradually tapering to a tapering pedicel 3-4 mm long, the top of the ovary glabrous. Sepals usually, but not invariably, deciduous, $1-1.5 \mathrm{~mm}$ long, almost hemispherical, glabrous except for few to numerous crisped hairs near the apex and on the margins, the centre usually dark like the hypanthium but the margins scarious and pale. Petals c. 3-4 mm long. Stamens in bundles of c. 5, 2.5-4 mm long, the anther-cells, c. $0.4 \mathrm{~mm}$ long, parallel, broad, often ultimately shallow but sometimes with the somewhat longer outer part deep (their opening restricted or tardy), often tending to curve back and to fold back. Style inset, broad-based and rather stout, with a small stigma. Ovary (3-) 5-locular, each loculus with $40-50$ ovules in 6 rows on a rather high, very large, rounded placenta. Fruit not persisting, 3.5-5 $\mathrm{mm}$ in diameter, glabrous, the upper part of the hypanthium broad, rim-like and erect, sometimes with some persisting calyx-lobes, the lower part narrower, lobed in cross-section and rather rounded above a tapering long stalk often 3-4 $\mathrm{mm}$ in length, the valves somewhat woody, much exserted and, before opening, high and domed so that the broad part of the fruit is almost spherical, but after opening spreading, often beyond the rim. Mature seeds c. $1.5 \mathrm{~mm}$ long, narrowly cuneiform, with an irregularly striate surface. Main flowering period: Nov.-Jan.

DisTRIBUTION: In the central and southern coastal regions of New South Wales and in East Gippsland, Victoria (Map 6). On river banks and in rocky stream beds.

Selected specimens: New South Wales: Central Coast: Nepean R., Deane NSW 156256, 9.1888 (NSW). South Coast: Currawan Creek, 10 miles [16 km] from Nelligen on Braidwood road, Constable NSW 44454, 10.1957. Central Tablelands: Nattai R., 

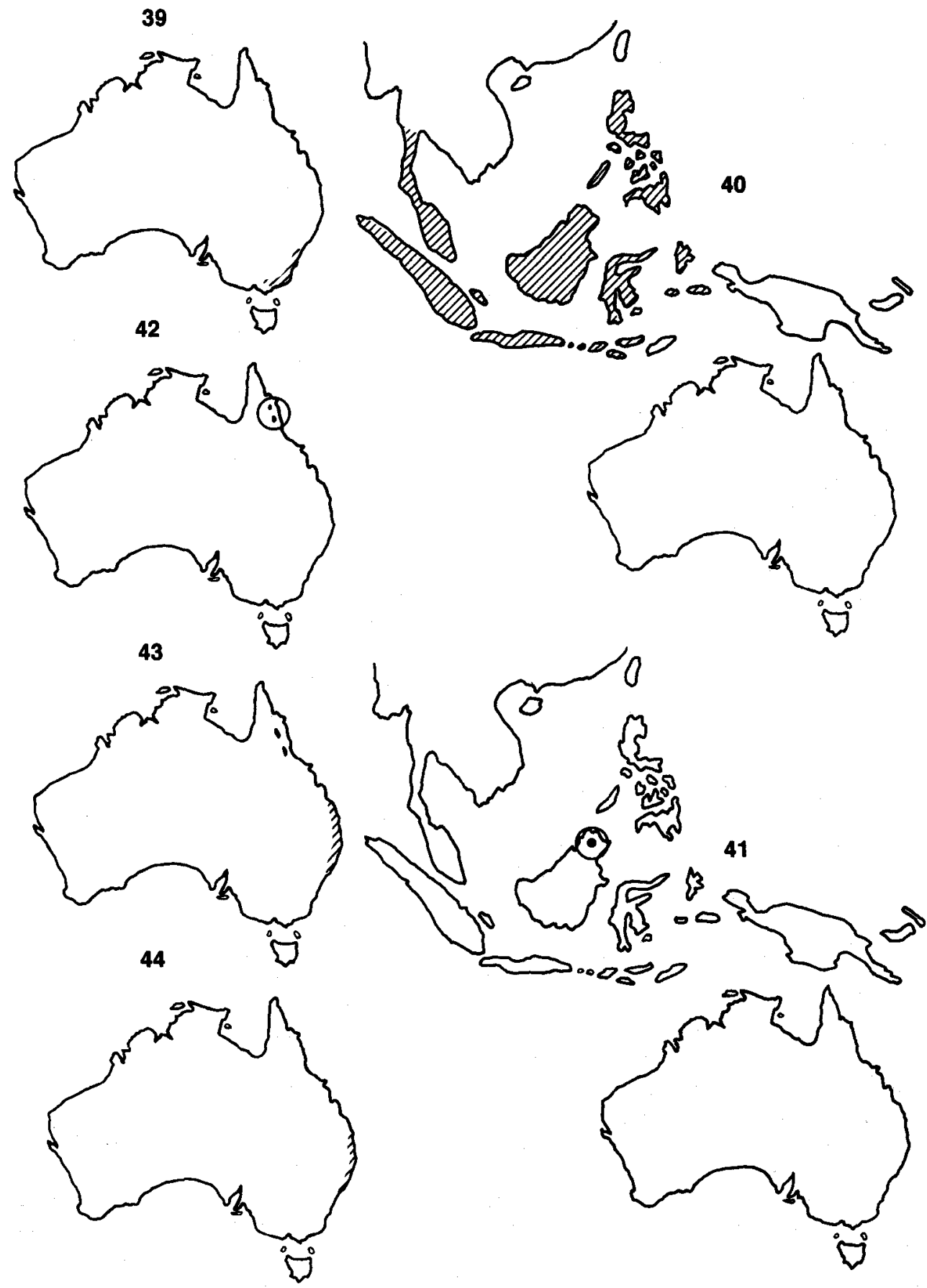

Map 6. Distribution of Group 2: subgroup 1 L. petersonii and allies. 39. L. emarginatum 40. L. javanicum 41. L. recurvum 42. L. wooroonooran 43. L. petersonii a. subsp. lanceolatum b. subsp. petersonii 44. subsp. liversidgei. 
near [Colo via] Hilltop, Cheel NSW 154931, 11.1911, NSW 154932, 12.1919, NSW 154933, 10.1920. VICTORIA: East Gippsland: Little R., Whaite NSW 154753, 1.1949.

40. L. javanicum Blume, Bijdr. 1: 1100 (1826).

HOLOTYPE: JAVA: in cacumine montis Gede (L).

SYNONYMY: Macklottia javanica (Blume) Korth., Ned. Kruidk. Arch. 1: 196 (1847).

Glaphyria nitida Jack, Trans. Linn. Soc. London 14: 128 (1823), non Leptospermum nitidum Hook. f. HolotYPE: Sumatra: Gunong Bunko, (n.v.), fide E.D. Merrill, Jack's genera and species of Malaysian plants, J. Arnold Arbor. 33: 226 (1952).

L. alpestre Blume, loc. cit. HolOTYPE: JAVA: in declivitatibus altioribus montis Gede (L).

L. amboinense Blume, loc. cit. HolotyPE: MolucCas: in Moluccis ... (L). Macklottia amboinensis (Blume) Korth., Ned. Kruidk. Arch. 1: 196 (1847). Blume did not base this species on Myrtus amboinense Rumphius as is assumed by many authors.

? L. floribundum Junghuhn, Natuur-Geneesk. Arch. Ned.-Indië 2: 34-54 (1845), non Salisb. HoloTYPE: JAVA: javanicae alpinae, but specimen not cited (?L, n.v.). From the detailed description this taxon matches high altitude forms of $L$. javanicum except for the description of the flowers as 'solitarii, sine plures (bini, terni) in axillis foliorum'. It is possible that the congested growth referred to has caused misinterpretation of the position of flowers.

L. annae Stein in Regel, Gartenflora.: 66 (1885). TYPE: Mt Apo, Philippines, n.v., fide Merrill, Enum. Philippine Plants: 184 (1923).

A shrub or tree often gnarled, to $8 \mathrm{~m}$ or more in height with persistent and rather flaky bark; the younger stems with a silky often rather persistent pubescence, a flange broad and rather thick, especially near the node, and extending around the sides of the leaf-base, and branching at $30^{\circ}-40^{\circ}$. Leaves divergent, usually 15-35 $\mathrm{mm}$ long and 3-7 $\mathrm{mm}$ wide, but occasionally much smaller, broadly oblanceolate to obovate or, often somewhat rhombically, elliptic, variable in texture, flat or with recurved margins, and glabrous for the most part but occasionally densely pubescent on the lower surface, the apex rounded, broadly obtuse or even minutely retuse with a small umbo behind the tip, or rather acute with a longer blunt point and somewhat recurved, often with a tuft of hairs, the base tapering, rather broad and petioleless with a thick midrib-base behind. Flowers white, rarely flushed pink, c. 10-12 $\mathrm{mm}$ in diameter, single or 2 or more together on modified shoots, terminal, in upper leaf-axils and on very short axillary branches, the rather pink new growth from the flowering region after or during flowering. Bracts broad, red-brown, the inner and the bracteoles relatively large and scarious, usually with dense cilia near the apex, often tending to persist about the flower. Hypanthium c. $2-3 \mathrm{~mm}$ long, very broad above and tapering to a short broad pedicel; glabrous or somewhat silkypubescent, with the surface rather dark coloured and with conspicuous glands, the top of the ovary glabrous. Sepals deciduous, sometimes tardily, c. 1.5-2 $\mathrm{mm}$ long, oblong to almost hemispherical, usually glabrous for the most part but with dense crisped hairs at the apex, variable in texture, hypanthium-like or with scarious margins or entirely scarious. Petals c. 4-6 mm long. Stamens in bundles of c. (3-) 5-7, 2-3 mm long, the anther-cells c. $0.2-0.3 \mathrm{~mm}$ long, usually parallel but occasionally separating, often recurved and rather deep especially the outer part. Style inset, but sometimes only shallowly so, usually rather slender with a broad or narrow base and small stigma. Ovary 5-locular at least for the most part, each loculus with c. 12-24 ovules in c. 4-6 rows on a high, rather small placenta with an often narrow top which is usually and somewhat variously extended. Fruit tending to persist but not on older branches, $4-8 \mathrm{~mm}$ in diameter, widest at the erect, rather than extended and woody, hypanthium-rim, the lower part often somewhat lobed in cross-section, at least at first, and very broad-based above a very short pedicel, the woody 
valves exserted, often forming a narrow-topped dome, to a distance almost equal to, or occasionally much exceeding, the base before opening, later spreading so as to be wider than the base and about equal to the rim occasionally with the base almost horizontal. Mature seeds c. 2-2.5 mm long, irregularly narrowly linear-cuneiform, striate. Flowering period: perhaps throughout the year.

Distribution: From Burma and southern Thailand to the Philippines, Moluccas and Lesser Sunda Islands (Map 6). In sandy and rocky places, especially on high mountains, usually on sandstone, granite or ultrabasic rocks.

Selected SPECIMENS: Borneo: Sabah: Peak Trail, Mt Kinabalu, $2200 \mathrm{~m}$ alt., Wallace 84379, 1.1984 (NSW). PhILIPPInes: Luzon: Lamao R., Mt Mariveles, Borden F.B. 788 , 5.1904 (NSW). Mindanao: Surigao Province, Ramos \& Paseasio B.S. 34493, 4.1919 (BRI, NSW); Todaya (Mt Apo), Elmer 10628, 5.1909 (NSW). JAVA: Mt Gede, Junghuhn (L). SulawesI: Mt Roroka Timbu summit, V. Balgooy 3323, 5.1979 (L). Ceram: Kairatu, Waiselang, Kuswaka \& Soepadmo 221, 6.1959 (NSW). LeSSER SUNDA IsLANDS: Manau near Ruteng, W. Flores, Kostermans \& Wirawan 594, 4.1965 (L).

The variation in this species does not allow subdivision into subspecific taxa on the evidence available at present. It would appear that the species has become diverse because it inhabits islands and "islands" of suitable habitat, mostly on nutrient-poor soils and high mountain-tops, to which it migrated probably by long-distance dispersal, and as a single event, from northeastern Australia where closely related species are still found.

Mueller (1890) and Diels (1922, as L. amboinense) refer to the presence of the species in New Guinea. From the description given, of a plant with flowers in terminal heads, these references are obviously based on material of another genus.

\section{L. recurvum Hook. f., Icon. Pl.: t. 893 (1852).}

HOLOTYPE: BORNEO:Kina Balu, abundant, from 7000-8500 feet, whitening the top of the mountain, H. Low, Esq. (K, n.v.).

Prostrate shrub, small tree or tree $20 \mathrm{~m}$ or more in height, with persistent rather flaky pale bark; the younger stems silky-pubescent or glabrous, with a broad and rather thick flange, especially near the node and extending around the sides of the leaf-base, the branching at c. $45^{\circ}$. Leaves divergent but usually strongly recurved so as to appear spreading, usually 3-6 $\mathrm{mm}$ long and 2-3 $\mathrm{mm}$ wide, broadly elliptical to orbicular-obovate, firm on the upper surface which is usually glabrous at least for the most part and usually glossy, the lower surface silky-pubescent or occasionally glabrous, the margins often strongly recurved, the apex strongly recurved or curled so as to appear retuse (actually broadly acute), often with a long tuft of hairs from behind the tip, the base tapering, broad and petioleless, and thickened by the stout midrib-base. Flowers white, c. $12 \mathrm{~mm}$ in diameter, single on modified shoots in upper leaf-axils and on very short axillary branches and perhaps also as axillary monads, the flowering area very condensed at branch-ends with several orders together, i.e. with a new shoot, often with pinkish-leaves, bearing new flowers found arising from the base of an old flower. Bracts broad and red-brown, the inner and bracteoles large, with at least some crisped hairs on the margins and at the apex, all tending to remain about the open flower. Hypanthium glabrous or with a somewhat spreading silky pubescence, or with dense curled hairs, the surface often tinged dark and sometimes with conspicuous glands, c. $2-3 \mathrm{~mm}$ long, very broad above and tapering to a very short or occasionally a $2 \mathrm{~mm}$ long pedicel, the top of the ovary glabrous. Sepals deciduous, c. $1.5-2 \mathrm{~mm}$ long, 
almost hemispherical, variably pubescent but if almost glabrous always with crisped hairs on the margins and at the apex, usually paler and thinner towards the margin. Petals c. $5 \mathrm{~mm}$ long. Stamens in bundles of $5(-7)$, c. $2.5 \mathrm{~mm}$ long, the anther-cells c. $0.3 \mathrm{~mm}$ long, parallel and rather deep, especially the outer part. Style inset, rather stout-based with a small stigma. Ovary 5-locular at least for the most part, each loculus with c. 20 ovules in c. 4 rows on a small high placenta, narrowed and variably extended at the top. Fruit tending to persist but not on older branches, c. $6-7 \mathrm{~mm}$ in diameter, widest just below the erect hypanthium-rim, tapering to or rounded above a short, broad, stalk-like section c. $1 \mathrm{~mm}$ long, the valves woody, before opening exserted to a distance almost equal to the broad part of the base, later opening wider so as to be wider than the base but about equal to the rim. Mature seeds c. $2-2.5 \mathrm{~mm}$ long, irregularly linear-cuneiform, striate. Flowering period: perhaps throughout the year.

Distribution: Endemic on Mt Kinabalu, Borneo (Map 6). In rock crevices and in sandy soils, on granite and on ultrabasic rocks at high altitudes.

Selected SPECIMENS: Borneo: Sabah: Panar Lahan, Mt Kinabalu, Wallace 84045, 84046, 1.1984 (NSW), Binideh Fl. Sabah. No. 65175, 11.1968 (L); Sayat-Sayat, Mt Kinabalu, Wallace 84037, 84038, 1.1984 (NSW).

The leaves of this species vary a great deal in shape, size and pubescence. In other characters it resembles $L$. javanicum from which it appears to be a high-mountain selection, endemic on Kinabalu. In view of the pattern of variability of L. javanicum and a similar, less successful, separation of a variant form of L. javanicum (Lee \& Lowry, 1980) in the Celebes, this taxon is treated as a species in this work only in order to follow current usage pending a detailed study of the group of species related to L. javanicum.

42. L. wooroonooran Bailey in Bailey \& A. Meston, Rep. Exped. Bellenden-Ker: 40 (1889).

HolotyPe: Queensland: South Peak, Bellenden-Ker, [F.M. Bailey, 22.6.1889] (BRI).

Dwarfed tree with a horizontal trunk and persistent and rather flaky fibrous bark; the younger stems silky, glabrescent, with a very conspicuous broad flange, broadest near the node where it is carried up beside the leaf-base and narrowing below, and with branching at an angle of $30^{\circ}-45^{\circ}$. Leaves usually divergent, mostly $1.5-2 \mathrm{~cm}$ long and 3-7 $\mathrm{mm}$ wide, rather rhombically oblanceolate, silky when young, quite firm in texture (considering the habitat), the upper surface somewhat thicker so that the margins tend to recurve, otherwise flat, the apex acute and recurved so as to appear retuse, the lower part tapering to a broad virtually petioleless base thickened at the back by the stout midrib. Flowers white, $12-20 \mathrm{~mm}$ in diameter, occurring singly on modified shoots usually on very short 1 -few-leaved (or with this leaf reduced to a bract) branches in adjacent axils, the somewhat reddish new growth extending from branch ends before and beyond the flowering region development. Bracts redbrown, rather scarious, the outer shorter, the inner and bracteoles relatively larger and concave, glabrous except near the top, and shed before the flower opens. Hypanthium glabrous, and often with obvious glands, $3.5-4.5 \mathrm{~mm}$ long, tapering from an expanded upper part to a short tapering pedicel, the top of the ovary glabrous. Sepals mostly readily deciduous, c. $2 \mathrm{~mm}$ long, broadly ovate, the centre and base thicker but the margins thin and pale, glabrous except for the dense crisped hairs on the margins and at the apex. Petals 4-6 mm long. Stamens in bundles of 3-5, 1.5->2 mm long, the anther-cells c. $0.5 \mathrm{~mm}$ long, parallel and folded back. Style inset, rather slender, the stigma not large. Ovary 
5-locular, each loculus with c. 12-24 ovules in c. 4 rows on a high placenta usually with a narrow top which is not much, if at all, extended. Fruit persistent, 4-5 $\mathrm{mm}$ in diameter, the hypanthium-rim expanded, ultimately horizontal, undulating and woody, in the lower part the fruit lobed in cross-section, relatively deep and rounded above or broadly tapering to a rather stout stalk c. 1 $\mathrm{mm}$ long, the valves somewhat woody, usually much shorter than the deep base and not spreading wider than the rim. Seeds (not seen mature) c. $2.5 \mathrm{~mm}$ long, striate. Main flowering period: Nov.

DISTRIBUTION: On the high granite mountains of far northern Queensland (Map 6 ). In wet cloudy sites on exposed rock outcrops or among rocks of streambanks.

Selected SPECIMENS: QueEnSLAND: Cook: Bellenden Ker, White, 1.1923 (BRI, NSW); summit of Centre Peak, Bellenden Ker, Cambage 3829, 8.1913 (NSW), Webb \& Tracy 10799, 11.1972 (BRI).

\section{L. petersonii Bailey, Queensland Agric. J. 15: 781 (1905).}

Holotype: QueEnSLAND: Wilsons Peak, W.J. Peterson, Jan. 1905 (BRI). IsotYPE: NSW.

SYNONYMY: Leptospermum flavescens var. citratum J.F. Bail. \& C.T. White [Queensland Agric. J., n.s. 5: 161, t. 2 (1916) nom. nud.], Bot. Bull. Dept. Agric. 18: 8, t. 2 (1916). SYNTYPES: QuEENSLAND: Springbrook, Macpherson Range, C.T. White, June 1914, Dec. 1915, Jan. 1916 (BRI).

Leptospermum citratum R.W. Challinor, Cheel \& A.R. Penfold, J. \& Proc. Roy. Soc. New South Wales 52: 175 (1918). TYPE: not designated.

Dense shrub or diffuse small tree to $5 \mathrm{~m}$ or more in height with rather flaky persistent fibrous bark; the younger stems slender, only briefly somewhat hirsute, soon glabrous, with a conspicuous, rather pale wide flange around each leaf-base and extending down the stem and a shallow ridge below the node, and with branching at an angle of $30^{\circ}-40^{\circ}$. Leaves aromatic, divergent to spreading, rarely deflexed, usually $20-40 \mathrm{~mm}$ long and $2-5 \mathrm{~mm}$ wide, elliptical to narrowly lanceolate, flat or with the margins tending to recurve, glabrous or with some hairs near the base, sometimes, especially on young growth, thin in texture, the apex acute or rounded, often retuse, sometimes tending to recurve, occasionally apiculate, the base tapering, lacking a petiole but broad-based with the midvein stout at the back. Flowers white, 10-15 mm in diameter, occurring singly, rarely 2 together, on modified shoots in adjacent leaf-axils or at the ends of very short axillary branches, with little, if any, development of the terminal bud, the new growth, often tinged red or purple, extending vigorously from beyond the the flowering region. Bracts rather pale red-brown and scarious, the outer short and broad, the inner and bracteoles thin, very large and glabrous except at the pubescent apex, all shed from well-developed buds. Hypanthium glabrous or almost so, usually rather dark-coloured and with obvious glands, 3-4 $\mathrm{mm}$ long, the upper part widely expanded, tapering to a broad base often with a very short broad pedicel, the top of the ovary glabrous. Sepals deciduous, occasionally somewhat tardily, $1.5-2.5 \mathrm{~mm}$ long, very broadly ovate to hemispherical, scarious and glabrous except for dense, crisped, fine hairs on the margins and especially dense at the apex. Petals c. 5-6 mm long. Stamens in bundles of 5-7, 2.5-3.5 mm long, the anther-cells c. $0.3-0.5 \mathrm{~mm}$ long, parallel and shallow or with the often much broader outer part deep. Style inset, tapering to a medium-sized stigma; occasionally reduced or absent. Ovary 5-locular, each loculus with c. 20-50 ovules in c. 6 rows on a broad, high placenta, extended but not much narrowed at the top; occasionally absent. Fruit persisting but on slender branches and not found on old wood, c. $6 \mathrm{~mm}$ in 
diameter, widest at the hypanthium-rim, the lower part very shallow and somewhat lobed in cross-section, the base broadly rounded, sometimes with a trace of a stalk, the valves rather woody, before opening exserted so as to be almost equal to the base but later spreading so as to be twice or more as deep and broader than the base, and as wide or even somewhat wider than the rim. Mature seeds c. $2 \mathrm{~mm}$ long, slender, irregularly narrowly linear-cuneiform, the surface finely striate. Main flowering period: Dec.-Jan.

Distribution: Scattered, from tropical Queensland to the Port Macquarie district of New South Wales (Map 6). In sandy soils, along creeks and on rocky escarpments near wet sclerophyll forest or rainforest.

\section{Key to subspecies}

1 Leaves narrowly lanceolate to elliptical, the leaf-apex usually retuse. Leaves often strongly lemon-scented ............ subsp. petersonii a.

$1^{*}$ Leaves lanceolate, the apex usually acute or rounded. Leaves not strongly lemon-scented ................. subsp. lanceolatum $\mathbf{b}$.

a. subsp. petersonii.

SYNONYMY: as for the species.

Leaves narrowly lanceolate to elliptical, tapering to a broad, usually retuse apex; often strongly lemon-scented. Main flowering period: Dec.-Jan.

DisTRIBUTION: From Fraser Island, Queensland, to the Port Macquarie district of New South Wales, on coastal flats and ranges and on the eastern edge of the Dividing Range (Map 6). On sandy soils, along creeks and on rock escarpments, often at the edge of wet sclerophyll forest or rainforest.

Selected SPECIMENS: QueEnSLAND: Wide Bay: Blackall Range, White, 4.1918 (BRI, NSW). Moreton: Mt Barney, Telford CBG 027967, 5.1969 (NSW). NEW SouTH WaLES: North Coast: Copmanhurst, Blakely \& Shiress NSW 143908, 9.1922 (NSW). Northern Tablelands: Lookout Point, Gibraltar Range, Constable NSW 143909, 4.1956 (NSW).

b. subsp. lanceolatum J. Thompson subsp. nov.

Folia aromatica sed non vixve citriodora, apice angusto non retuso.

Holotype: New South Wales: cultivated Castle Hill [Sydney] from seed ex Herberton distr., C. Debenham s.n. [ex Museum of Applied Arts and Sciences Herbarium Sydney, N.S.W.], 9.1965 (NSW).

Leaves lanceolate, tapering to an acute or narrowly rounded and often apiculate apex; aromatic with a spice-like odour but scarcely if at all lemon-scented. Main flowering period: Jan.

DistribuTION: In the North Kennedy District of tropical Queensland (Map 6). In sandy soils, on creek banks and escarpments on rainforest margins.

SELECTED SPECIMENS: QUEENSLAND: North Kennedy: Herberton, Michael NSW 154754, 1.1918 (NSW); Wild R. watershed, Volk [ex Museum of Applied Arts and Sciences herbarium], 4. 1957 (NSW), 5.1957 (NSW); Mt Spec area, $12 \mathrm{~km} \mathrm{W.} \mathrm{of} \mathrm{Paluma} \mathrm{town-}$ ship, Jackes NSW 154755, 8.1980 (NSW). 
Neither subspecies is known from a large number of field collections, and although ssp. petersonii is widely cultivated it is unlikely that cultivated specimens display the whole variation found within the subspecies. Certainly collections have been made in New South Wales which lack the distinctive lemonscent and leaf-apex. Further collections of both subspecies may reveal other characters by which they can be distinguished, or on the other hand new collections may blur the distinction. It seems advisable on our present knowledge to recognise the taxa at subspecific level.

This species needs examination in relation to $L$. javanicum. Some specimens of that species from Flores in the Lesser Sunda Islands show a remarkable similarity to some specimens of the northern subspecies of L. petersonil. However the valves of $L$. petersonii do not appear to form an acute high dome, with the greatest height near the style, in the young fruit, a feature that appears to be characteristic of $L$. javanicum.

44. L. liversidgei $R$. Baker \& H.G. Smith, J. \& Proc. Roy. Soc. New South Wales 39: 124 , t. 2 (1906).

LeCtotype, here chosen: New South Wales: Ballina, D.W. Munro s.n., March 1905 (NSW).

SYNONYMY: Leptospermum flavescens var. citriodorum Bailey, Queensland Agric. J. 15: 781 (1905). L. polygalifolium var. citriodorum (Bailey) Domin, Biblioth. Bot. 89: 452 (1928). LeCTOTYPE, here chosen: QueEnSLAND: Peel Island [Moreton Bay], W. Soutter s.n., 1904 (NSW). ISOTYPE: BRI.

Compact shrub to $4 \mathrm{~m}$ in height, but often $0.5 \mathrm{~m}$ or less, with close bark; the younger stems slender, with a short, often crisped, pubescence, without a flange but enlarged just below each leaf-base, their branching at from $0^{\circ}$ (flush with the stem) to $45^{\circ}$ but most stems at a narrow angle. Leaves lemon-scented, dense and erect to spreading, usually 5-7 $\mathrm{mm}$ long and 1-2 $\mathrm{mm}$ wide, narrowly obovate, thick especially in the upper part and somewhat incurved from the margins, glabrous, with the apex broadly acute to obtuse, often with an umbo behind the somewhat recurved tip, and long-tapering at the base to an, often very short, petiole. Flowers white or pink, c. 10-12 $\mathrm{mm}$ in diameter, occurring singly on modified shoots at the ends of short few-leaved branches in adjacent axils, and occasionally of long slender leafy branches, with little, if any, development of the terminal shoot-bud, the new growth, sometimes with coloured tips, is developed vigorously elsewhere, both above and below the flowering region, at, and after, flowering-time. Bracts short, broad and rather pale and scarious; the bracteoles very concave, red-brown and scarious, enclosing the flat-topped young bud but soon shed so that only the bracts remain. Hypanthium glabrous or minutely pubescent, and dark-coloured with rather conspicuous glands, c. $2.5 \mathrm{~mm}$ long, at first evenly tapering, later very broad above and with a distinct broad pedicel 1-1.5 mm long, the top of the ovary glabrous. Sepals persistent or tardily deciduous, c. $2 \mathrm{~mm}$ long, almost hemispherical to deltoid, dark, with pale scarious margins, glabrous, or somewhat erose at the apex. Petals c. $5 \mathrm{~mm}$ long. Stamens in bundles of 5-7, 1.5-2.5 mm long, the anther-cells c. $0.4 \mathrm{~mm}$ long, parallel, broad and with the outer part larger and often deeper though ultimately shallow, not recurved but tending to fold back. Style inset, rather stout and tapering slightly to behind a very large stigma. Ovary (3-) 5-locular, each loculus with c. 10-20 ovules in c. 6 rows on a high placenta extended but narrowed (acute) at the top. Fruit persistent often with the base tending to be sunk in the stems, usually $7-10 \mathrm{~mm}$ in diameter, much wider than deep, with a broad, very woody, rim, below this tapering to 
the base (i.e. without the pedicel found in the flower), the surface firm and wrinkled, the valves very thick and woody, on opening exserted to c. $1 / 2$ the depth of the base, later spreading but not wider than the rim. Mature seeds $\mathrm{c}$. 1.5-2 mm long, irregularly cuneiform, striate with the striations tending to lift. Main flowering period: Jan.

Distribution: From the Bundaberg district of Queensland to Port Stephens in central New South Wales (Map 6). In coastal low-lying, sandy and peaty swampy heath.

SELECTED SPECIMENS: QUEENSLAND: Wide Bay: Fraser Island, White, 10.1921 (NSW). Moreton: Bilinga [as Belinga], Jackson, 1.1931 (NSW). NEW SouTH WALES: North Coast: Diamond Head, Crowdy Bay National Park, Coveny 9892 \& Haegi, 11.1977 (NSW); Bombah Point, Myall Lake, Constable NSW 19175, 1.1952 (NSW).

\section{L. polygalifolium subgroup (spp. 45-51), Map 7.}

45. L. polygalifolium Salisb., Prodr. 350 (1796); Domin, Biblioth. Bot. 89: 451 (1928).

Holotype: juxta Port Jackson [New South Wales], legit Dav. Burton (? K, n.v.).

Synonymy: L. flavescens Smith, Trans. Linn. Soc. London 3: 262 (1797). HolotyPE: NeW South WALES: Port Jackson, $M r$ White $878.8,1795$, (LINN, n.v., photo NSW \& BRI).

L. porophyllum Cav., Icon. 4: 17, t. 330, fig. 2 (1797). Holotype: New South Wales: prope oppidum Jackson in Nova-Hollandia, herb. Née (MA, n.v.).

L. stellatum Cav., loc. cit., partim, the protologue containing elements of $L$. trinervium. TYPE: New South Wales: Port Jackson, herb. Née, fl. April (MA, n.v.).

Melaleuca thea Wendl. f. \& Schrader, Sert. Hannov.: 24, t. 13 (1797). Leptospermum thea (Wendl. f. \& Schrader) Willd., Sp. Pl. 2: 949 (1799). TYPE: The illustration, t.13.

L. flavescens var. commune Benth., Fl. Austral. 3: 104 (1867). L. polygalifolium var. commune (Benth.) Domin, Biblioth. Bot. 89: 452 (excl. specimen cited). TYPE: Bot. Mag. t. 2695 .

L. flavescens var. microphyllum Benth., loc. cit. SYNTYPES: "chiefly in Queensland" (K, n.v.).

L. flavescens var. leptophyllum Cheel in A.R. Penfold, J. \& Proc. Roy. Soc. New South Wales 56: 166 (1922). HolotyPE: NeW South WALES: Copmanhurst, Clarence R., J.L. Boorman NSW (? timber no.) 11594, 5.1916 (NSW).

Shrub, often from 0.5 to $3 \mathrm{~m}$ in height, or slender to stout-trunked tree to $7 \mathrm{~m}$ or more, the bark usually close and firm but soft, thick and rather flaky in some arborescent forms; the younger stems at first with a short close pubescence but usually becoming glabrous, with a conspicuous flange, usually broad and often thick, especially near the node, and spreading or tending to curve around the stem, and with branching at from less than $30^{\circ}$ to more than $60^{\circ}$. Leaves sometimes aromatic, but not strongly so, usually somewhat divergent to spreading or occasionally deflexed, from less than 5 to more than $20 \mathrm{~mm}$ long and $1-5$, usually $2-3, \mathrm{~mm}$ wide, oblanceolate-elliptical to narrowly linear-elliptical, variable in texture, flat or with the margins recurved, usually glabrous or almost so, the apex broadly to narrowly acute or obtuse, the tip often recurved, with an umbo behind or with a short soft or stiff blunt point or occasionally a short pungent point, the base tapering and petioleless or virtually so. Flowers white, often greenish or creamy-white, or occasionally pink, usually $10-15 \mathrm{~mm}$ in diameter, occurring singly on modified shoots at the ends of very short or long leafy axillary branches, often in adjacent axils and on adjacent branches with the new growth extending, mostly from branch-ends during or after flowering. 
Bracts broad, almost spherical, dark red-brown and scarious; the bracteoles similar, some often persisting to the opening bud stage but sometimes shed early. Hypanthium usually glabrous and often rather dark with somewhat conspicuous glands, usually 2-4 $\mathrm{mm}$ long, the upper part expanded, the lower tapering to the base or tapering to, or rounded above, a pedicel often to c. 1 $\mathrm{mm}$ in length, the top of the ovary glabrous. Sepals deciduous, $1.5-2.5 \mathrm{~mm}$ long, usually broadly ovate-oblong, obtuse, glabrous or with minutely ciliate margins, scarious and pale at least at the margins. Petals 4-6 mm long. Stamens in bundles of 5-7 (-9), (2-) 2.5-4 (-4.5) $\mathrm{mm}$ long, the filaments broad in the lower part and tending to join at the extreme base, the anther-cells $0.4-0.5 \mathrm{~mm}$ long, usually well separated and often tending to diverge, very deep and with their opening restricted. Style inset, stout-based and tapering to a variable-sized stigma; sometimes absent. Ovary 5-locular (rarely and ? aberrantly less or more so), each loculus with (20-) 80-100 ovules in (4-) 8 rows on a large close, or occasionally smaller and extended, placenta; sometimes absent. Fruit persistent but not long-persistent and enlarging, 5-8 (-c. 10) $\mathrm{mm}$ in diameter, widest at a narrowly extended rim and usually rounded below to the base or to a short stalk, the valves exserted, before opening with a high or broad dome rather symmetrical with the almost spherical to broad and shallow wide part of the fruit, later often but not always opening so wide as to exceed the rim and reduced the depth of the base. Mature seeds 1.5-2.5 (-3) mm long, irregularly narrowly linear-cuneiform, curved, and striate with the surface fibres tending to loosen and diverge. Main flowering period: Aug.-Jan.

Distribution: From Cape York in Queensland to the central South Coast district of New South Wales, extending inland beyond the ranges and to Lord Howe Island (Map 7). Usually in sandy soil or on sandstone rocks but sometimes on basalt soils and rocks. The regional forms of this species are treated here as subspecies. It is possible that, with further study, some may be shown, as was $L$. morrisonii, to be species. They are all closer to one another than to any other species of Leptospermum. Each is variable and how much of this variation is a response to the habitat and how much genetic is a matter at present for conjecture. Penfold (1922) considered the analysis of the essential oils of what we now know as subspp. polygalifolium, transmontanum and cismontanum to show differences. Considerable uniformity in leaf-shape and other features is seen in some populations but within each subspecies there is a variety of further forms. This gives some phenotypic overlap between the subspecies as delimited here, and the extent to which this is caused by local selection of superficially similar forms or actual intermingling of the subspecies is not known. The Type subspecies is the most variable, but whether this is because it is the least specialised form or because it has originated from a merging of taxa is a further matter for speculation. The following key is based on herbarium specimens and is valid for the majority of specimens in each taxon. A number of specimens of this species cannot with confidence be assigned to subspecies. Specimens from far northern New South Wales and southern Queensland may be confused with $L$. variabile in the absence of flowers.

\section{Key to subspecies}

1 Leaves with the margins tending to recurve, not or rarely stiff in texture, the lower surface usually paler, the apex acute or obtuse.

2 Leaves usually acute or, if obtuse, more than $2 \mathrm{~mm}$ broad, usually more than $10 \mathrm{~mm}$ long, variable in colour. 

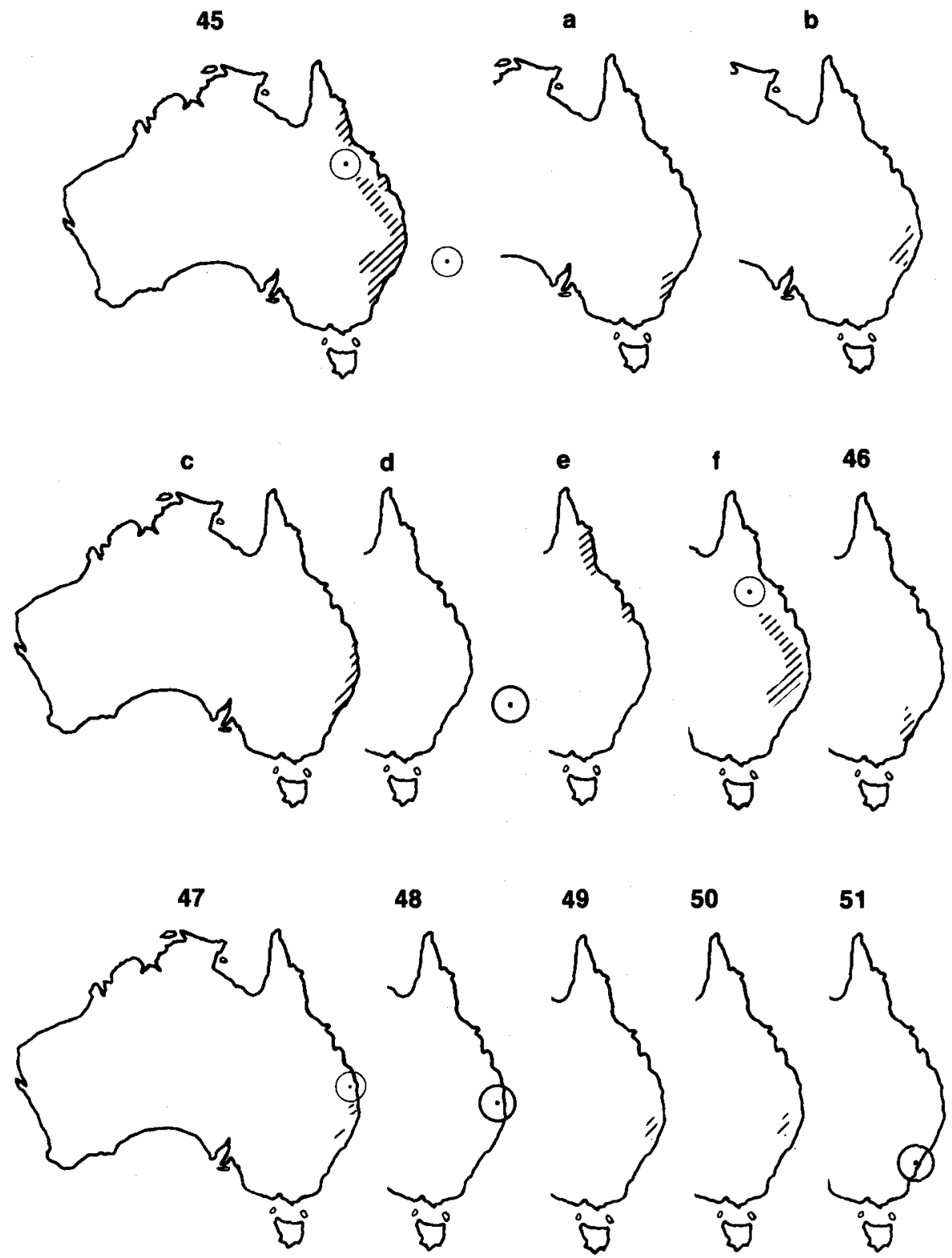

50

51
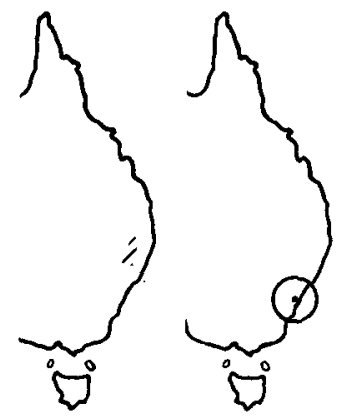

Map 7. Distribution of Group 2: subgroup 2 L. polygalifolium and allies. 45. $L$. polygalifolium a. subsp. polygalifolium b. subsp. montanum c. subsp. cismontanum d. subsp. howense e. subsp. tropicum f. subsp. transmontanum 46. $L$. morrisonii 47. $L$. variabile 48. L. oreophilum 49. L. novae-angliae 50. L. minutifolium 51. L. sejunctum. 
3 Leaves usually glabrous, $2-3 \mathrm{~mm}$ wide ..... subsp. polygalifolium a.

3* Leaves usually silky-pubescent on young growth, often more than $3 \mathrm{~mm}$ wide $\ldots \ldots \ldots \ldots \ldots$ subsp. montanum b.

$2^{*}$ Leaves usually obtuse, c. 8-10 $\mathrm{mm}$ long (longer in a riparian form) and about $2 \mathrm{~mm}$ wide, usually a characteristic dull grey-green colour. . . . . . . $\ldots \ldots \ldots \ldots \ldots \ldots \ldots \ldots \ldots \ldots \ldots$ subsp. cismontanum $\mathbf{c}$.

$1^{*}$ Leaves usually flat and rather stiff in texture, with the lower surface not conspicuously different in colour; leaf-apex usually acute.

4 Hypanthium c. $4 \mathrm{~mm}$ long; flowers often $15 \mathrm{~mm}$ in diameter; leaf-colour variable $\ldots \ldots \ldots \ldots \ldots \ldots \ldots \ldots \ldots \ldots$ subsp. howense $\mathrm{d}$.

4* Hypanthium usually 2-3.5 mm long; flowers mostly $10-12 \mathrm{~mm}$ in diameter; leaves usually a light rather yellowish, green.

5 Leaves usually $1.5 \mathrm{~mm}$ or less in width; placenta high and with c. 20-60 ovules $\ldots \ldots \ldots \ldots \ldots \ldots \ldots \ldots$ subsp. tropicum e.

$5^{*}$ Leaves usually more than $1.5 \mathrm{~mm}$ wide; placenta not high and with c. 80 ovules .................. subsp. transmontanum $\mathbf{f}$.

\section{a. subsp. polygalifolium}

HolotyPE: as for the species.

SYNONYMY: L. flavescens Sm., Trans. Linn. Soc. London 3: 262 (1797). L. porophyllum Cav., Icon. 4: 17, t. 330, fig. 2 (1797). Melaleuca thea Wendl. f. \& Schrader, Sert. Hannov: 24, t. 13 (1797). L. thea (Wendl. f. \& Schrader) Willd., Sp. Pl. 2: 949 (1799). L. flavescens var. commune Benth., Fl. Austral. 3: 104 (1867) p.p. L. polygalifolium var. commune (Benth.) Domin, Biblioth. Bot. 89: 452 (1928) excl. cited specimen.

Rather slender shrub 1-3 m or more in height, occasionally a small tree to $5 \mathrm{~m}$ or more. Leaves oblanceolate or occasionally almost elliptical, usually 10-20 $\mathrm{mm}$ long and c. $2(-3) \mathrm{mm}$ wide, the apex broadly to narrowly acute with a soft or occasionally pungent short point, the margins often recurving, the surfaces usually glabrous, the lower often much paler. Flowers $(10-) 12(-15) \mathrm{mm}$ in diameter, greenish or creamy white. Hypanthium $2.5-3.5 \mathrm{~mm}$ long. Sepals $2-2.5 \mathrm{~mm}$ long, usually scarious only near the margin. Ovary 5-locular with c. 50-100 ovules in each loculus. Fruit $6-10 \mathrm{~mm}$ or more in diameter and, after opening, with the base usually very shallow and the valves spreading widely. Mainly flowering period: Nov.-Dec.

DISTRIBUTION: Widespread on the tablelands and coast of central eastern New South Wales, extending southward along the coast (Map 7). In heath or dry sclerophyll forest, usually on sandstone, in deep sand or skeletal soils, often in moist depressions or along rocky watercourses.

Selected specimens: New South Wales: Central Coast: Port Jackson, White, 1795 (photos LIVCM: 1909. LBG.8816 (LIV, NSW) and ex K (BRI, NSW)); on banks of Nepean R., c. 4 miles [6.5 km] S. of Wallacia, Salasoo 2653, 12.1963 (NSW). South Coast: near Burrewarra Point, S. of Batemans Bay, Craven 601, 10.1965 (CANB, NSW). Central Tablelands: Dante Glen track, Lawson, Coveny 9842, 11.1977 (NSW). Southern Tablelands: above Sassafras, Thompson 4055, 4.1979 (NSW).

b. subsp. montanum J. Thompson subsp. nov.

Folia plerumque $10-15(-20) \mathrm{mm}$ longa et $3(-5) \mathrm{mm}$ lata, margine recurvata late obtusa ad anguste acuta, pagina inferiore plerumque pallidiore. 
Holotype: New South Wales: Yarrowitch, J.L. Boorman NSW 15040, 12.1912 (NSW).

Shrub often 1-2 m high, taller and often becoming a tree of $7 \mathrm{~m}$ or more in sheltered forest. Leaves oblanceolate-elliptical, usually $10-15(-20) \mathrm{mm}$ long and often 3 , occasionally up to 5 , mm wide, the apex broadly to narrowly acute or broadly obtuse, the tip sometimes with a blunt point, the margins tending to recurve, the surfaces often at first silky, later glabrous, the lower paler. Flowers c. $12 \mathrm{~mm}$ in diameter, white. Hypanthium c. $3 \mathrm{~mm}$ long. Sepals c. $1.5-2 \mathrm{~mm}$ long, usually scarious only near the margins. Ovary 5-locular with c. 30-100 ovules in each loculus. Fruit 6-(7-8)-9 $\mathrm{mm}$ in diameter, ultimately with the valves spreading widely and the base flat above a distinct stalk. Main flowering period: Nov.-Jan.

DisTRIBUTION: From the mountains of southeastern Queensland, through the tablelands and adjoining coastal areas of New South Wales to Barrington Tops (Map 7). Along watercourses, among, or in crevices of, granite boulders or on basalt rock outcrops.

SEleCted SPECIMENS: QueENSLAND: Darling Downs: Mt Cordeaux, near Cunninghams Gap, Briggs NSW 154818, 6.1961 (NSW). NEW SouTH WALES: North Coast: Kendall, Byrnes 3492, 12.1976 (BRI, NSW). Northern Tablelands: Walcha, Boorman NSW 143912, 12.1912 (NSW).

This can be distinguished from other species of this region, such as $L$. variabile and $L$. novae-angliae, which are similar in appearance, by its more delicate fruit with widely spread valves and almost flat base above a short stalk.

c. subsp. cismontanum J. Thompson subsp. nov.

Folia plerumque $8-10 \mathrm{~mm}$ longa et $2 \mathrm{~mm}$ lata, obscure viridia margine recurvata, plerumque late obtusa, pagina inferiore plerumque pallidiore.

Holotype: New South Wales: 6 miles [ $10 \mathrm{~km}$ ] NE. of Dungog on Stroud road, $J . M$. Powell 200 \& J. Seur, 30.ix.1975 (NSW). IsOTYPES: K, L, n.v.

SYNONYMY: L. flavescens var. microphyllum Benth., Fl. Austral. 3: 105 (1867).

L. flavescens var. leptophyllum Cheel in A.R. Penfold J. \& Proc. Roy. Soc. New South Wales 56: 166 (1922), quoad Typum.

Shrub 1-4 m in height, or small slender tree. Leaves elliptical or broader in the upper part, usually 8-10 $\mathrm{mm}$ long and $2 \mathrm{~mm}$ wide but occasionally longer and often then slender (the riparian form described by Cheel), the apex usually rounded with an umbo at the back, the margins recurved, the surfaces usually glabrous and a dull grey-green in colour, the lower usually much paler. Flowers c. $10 \mathrm{~mm}$ in diameter, white. Hypanthium $2.5-3 \mathrm{~mm}$ long. Sepals $1.5-2 \mathrm{~mm}$ long, with thin pale margins and apex. Ovary 5-locular with c. 80 ovules in each loculus. Fruit often $5-7 \mathrm{~mm}$ in diameter, only occasionally with the valves spreading widely and the base shallow. Main flowering period: Sept.-Oct.

DiSTRIBUTION: From Fraser Island, Queensland, through coastal New South Wales, to the Gosford district (Map 7). In sandy and peaty coastal swamps, on old dunes and on hillsides, especially on sandstone, in dry sclerophyll forest.

SELECTED SPECIMENS: QueENSLAND: Wide Bay: Fraser Is., Queensland Director of Forests per Penfold NSW 154819, 3.1921 (NSW), NSW 154820, 8.1922 (NSW). Moreton: Nundah Creek, White, 11.1915 (NSW), 9.1916 (NSW). New SouTH WaLEs: North Coast: Lake Cathie, $14 \mathrm{~km} \mathrm{SW}$. of Port Macquarie, Jackson 53, 10.1978 (CBG, NSW). Central Coast: Kincumber road, near Gosford, Fletcher NSW 15038, 9.1885 (NSW). 
d. subsp. howense J. Thompson subsp. nov.

Folia plerumque $5-8 \mathrm{~mm}$ longa et $1.5-2 \mathrm{~mm}$ lata, plana acuta, paginis similibus.

Holotype: LoRd Howe Island: Mt Gower, a little above Get Up Place, A.N. Rodd 3589, 27.xi.1980 (NSW).

Bushy shrub $2 \mathrm{~m}$ or more in height or, in sheltered places, a tree to $6 \mathrm{~m}$ or more with a stout, often leaning, trunk. Leaves narrowly obovate-elliptical, usually 5-8 $\mathrm{mm}$ long and 1.5-2 $\mathrm{mm}$ wide, the apex acute, often with the tip recurved or with a short, blunt point, the surface flat and usually glabrous, with both sides relatively similar. Flowers c. $15 \mathrm{~mm}$ in diameter, white. Hypanthium c. 4 $\mathrm{mm}$ long. Sepals 2-2.5 mm long and very pale and scarious. Ovary 5-6 or more- locular with c. 100 ovules in each loculus. Fruit $5-8 \mathrm{~mm}$ in diameter, the valves not or tardily spreading wide. Main flowering period: Nov.-Jan.

DiSTRIBUTION: In southern Lord Howe Island (Map 7). On basalt cliff-ledges and mountain summits, often in closed montane forest.

SEleCted SPECIMENS: LORD Howe IsLAND: Boat Harbour track, Pickard 3540, 7.1978 (NSW), Norris 48, 12.1983 (NSW); summit ridge of Mt Lidgbird, Pickard 1452, 5.1971 (NSW); summit of Mt Gower, Johnson \& Rodd 1364, 9.1970 (NSW).

e. subsp. tropicum J. Thompson subsp. nov.

Folia 5-20 mm longa et 1-1.5 mm lata, plerumque flavovirentia plana acuta, paginis similibus.

Holotype: QUeENSLAND: c. $10 \mathrm{~km}$ from Byfield on track to Five Rocks, J.M. Powell 882 \& J. Armstrong, 20.ix.1977 (NSW).

Shrub from 0.5 to more than $1.5 \mathrm{~m}$ in height, occasionally a small tree. Leaves very narrowly linear-elliptical, usually 5-20 $\mathrm{mm}$ long and $1-1.5 \mathrm{~mm}$ wide, the apex tapering to an acute, often bluntly pointed and often recurved tip, the surface flat and glabrous with both sides relatively similar and usually a light, rather yellowish green. Flowers c. $10-12 \mathrm{~mm}$ in diameter, white or pink. Hypanthium 2-3 mm long. Sepals c. $2 \mathrm{~mm}$ long, scarious and pale, at least on the edge. Ovary 5-locular with 50-60 ovules on a rather small and high placenta in each loculus. Fruit c. 5-6 $\mathrm{mm}$ in diameter, often almost spherical and usually with the base deep after opening. Main flowering period: Aug.-Sept.

DiSTRIBUTION: On the eastern tropical coast and ranges of Queensland, from north of Cooktown to Keppel Bay (Map 7). In wet coastal heaths, on dunes and in open woodland on sandy soils.

SELECTED SPECIMENS: QueEnsLand: Cook: Walshs Pyramid, Bailey, (received 1918, NSW). North Kennedy: c. $4.2 \mathrm{~km}$ SW. from Herberton along Silver Valley road, Conn and Clarkson 1161, 5.1983 (MEL, NSW); $12 \mathrm{~km}$ W. of Paluma, Jackes \& Jackes, 9.1982 (NSW). Port Curtis: Shoalwater Bay, strait S. of Townshend Is., Brown, 8.1802 (NSW); Byfield, White 8027 (bis), 9.1931 (BRI, NSW), Gittins 2551, 8.1972 (NSW).

f. subsp. transmontanum J. Thompson subsp. nov.

Folia 10-15 mm longa et $2 \mathrm{~mm}$ lata, flavovirentia plana acuta, paginis similibus.

Holotype: New South Wales: Etoo Creek, $4 \frac{1}{2} 2$ miles [7 km] NE. of Gwabegar, L.A.S. Johnson \& E.F. Constable NSW 30226, 3. Nov. 1954 (NSW). 
Shrub 1-4 m in height, or occasionally a small tree. Leaves narrowly, rather irregularly elliptical, usually $10-15 \mathrm{~mm}$ long and c. $2 \mathrm{~mm}$ broad, tapering to an acute, even pungent, apex, the surface flat and usually glabrous, with both sides similar and usually a light yellowish green. Flowers c. 10-12 $\mathrm{mm}$ in diameter, rather greenish white or pink. Hypanthium 2.5-3 mm long. Sepals c. 1.5-2 mm long and usually pale and scarious only at the edges. Ovary 5-locular with c. 80 ovules in each loculus. Fruit (5-) 6-7 (-8) $\mathrm{mm}$ in diameter, often with the valves not widely expanded and the base rather deep. Main flowering period: Aug.-Jan. (Aug.-Sept. in Queensland, Oct.-Nov. on the western slopes of New South Wales, Dec.-Jan. on the tablelands.)

DisTRIBUTION: From the White Mountains of northern inland Queensland to the Hunter River district of New South Wales (Map 7). Usually in dry sandy alluvial soil but also in rocky places especially along watercourses in dry sclerophyll forest.

SELECTED SPECIMENS: QueENSLAND: Burke: Wall Creek, White Mtns, Godwin NSW 154821, 8.1984 (NSW). Leichhardt: Blackdown Tableland, summit of N. escarpment, Gittins S/63, 8.1964 (NSW). Burnett: Goodyer, Michael 2958, 9.1945 (BRI, NSW). Darling Downs: Chinchilla, Beasley, 5.1912 (NSW). New South WaLES: Northern Tablelands: $38 \mathrm{~km}$ from Walcha on "Moona Plains" road, Jacobs, Wilson \& Lapinpuro LL02, 9.1982 (NSW). Central Tablelands: 1 mile [1.6 km] E. of Currant Mtn Gap, Rylstone district, Briggs NSW 154822, 8.1961 (NSW). North Western Slopes: near Wiggans Creek, Pilliga scrub, Thompson 2975, 11.1978 (NSW). North Western Plains: Narrabri, Penfold NSW 154823, 154824, 9.1921 (NSW).

\section{L. morrisonii $J$. Thompson sp. nov.}

Frutex vel arbor usque ad plus quam $5 \mathrm{~m}$ alta. Folia elliptica ad oblanceolata saepe plus minusve falcata, $1.5-3.5 \mathrm{~cm}$ longa. Flores $12-15 \mathrm{~mm}$ diametro, sepalis glabris deciduis. Ovarium 5-loculare. Fructus $6-10 \mathrm{~mm}$ diametro persistentes.

Holotype: New SOUTH WALES: sandstone cliffs c. $1 / 2$ mile $[0.8 \mathrm{~km}] \mathrm{NW}$. of Dhruwalgha Mt., SE. of Robertson, $H$. Salasoo 3166, 11.1.1966 (NSW).

SYNONYMY: L. virgatum S. Schauer, Linnaea 4: 410 (1842) non Forst. \& Forst. f. TYPE: Blue Mountains [New South Wales], A. Cunningham, 1822 (?, n.v.).

Bushy shrub or small tree from c. 2 to more than $5 \mathrm{~m}$ tall with firm ultimately corrugated bark; the younger stems with a short, rather persistent pubescence, a pale and thick flange, broad near the node but often tending to curve around the stem, and with branching at c. $30^{\circ}$. Leaves strongly aromatic, most divergent but some older ones becoming deflexed, very variable in size but most 15-35 mm long and 2-8 $\mathrm{mm}$ wide, usually narrowly elliptical to oblanceolate and somewhat falcate, firm and flat or somewhat recurved at the margins, silky-pubescent at first but usually soon glabrous, first on the upper surface, the apex usually tapering gradually and acute, with a blunt and often infolded point but occasionally rounded, the base tapering and not or scarcely petiolate. Flowers white or rather greenish creamy white, usually $12-15 \mathrm{~mm}$ in diameter, occurring singly in modified shoots at the ends of short, leafless to long, leafy axillary branches in adjacent axils, the new growth usually vigorous and purple and extending from branch-ends during flowering with little development later in the flowering region. Bracts very broad, red-brown and scarious, the inner and bracteoles large, orbicular and similar, most shed from the opening bud but some attached below the open flower. Hypanthium c. $4 \mathrm{~mm}$ deep, the upper part very broad, tapering rather abruptly to a narrow pedicel, the outer surface 
glabrous and rather dark, the top of the ovary glabrous. Sepals deciduous, 2.5-3.5 mm long, almost spherical, very thin and scarious, pale and glabrous. Petals 5-7 mm long. Stamens in bundles of 7-9, 3.5-4.5 mm long, the filaments broad at the extreme base and tending to join, the anther-cells $0.4-0.5 \mathrm{~mm}$ long, often well-separated with some tending to diverge, very deep, with a broad outer edge, their opening very restricted. Style inset, usually very stoutbased and tapering to a rather large stigma; often absent. Ovary 5-locular, each loculus with c. 120 ovules in c. 10 rows on a large close-set placenta; sometimes absent. Fruit persistent, usually $6-10 \mathrm{~mm}$ in diameter, widest on the extended but not very woody rim, and below this shallowly rounded above a short stalk-like section, the valves woody and before opening forming a broad high dome larger than the lower part of the fruit, later spreading, often so as to exceed the rim, the base often becoming very shallow but not flat. Mature seeds c. $2 \mathrm{~mm}$ long, irregularly narrowly linear-cuneiform or sigmoid, curved, the striate surface often loosening. Main flowering period: late Dec.-Jan.

DistribUTION: In central coastal and tableland areas of New South Wales (Map 7). On exposed rocky sandstone or basalt escarpments, on hill slopes or on rocky creek banks or sandy alluvium.

SEleCted SPECIMENS: New SOUTH WALES: Central Coast: Illawarra, Macarthur 133, 1855 (NSW). South Coast: Tianjara Creek, Vickery NSW 14163, 1.1937 (NSW). Central Tablelands: Excelsior, Boorman NSW 15037 p.p., 1.1914 (NSW); Kanangra Tops, Hind 731, 7.1975 (NSW), Thompson 4307, 8.1982 (NSW); Welby Dam, Brophy 255, 11.1987 (NSW). Southern Tablelands: Corang R. on Nerriga-Windellama road, Orchard 4486, 2.1975 (NSW).

This species is named for David Morrison, whose work on genecological differentiation between related taxa in the Sydney region strongly supported the recognition of this taxon as a species. See D.A. Morrison \& P.J. Myerscough (1982) and D.A. Morrison (1984).

\section{L. variabile $J$. Thompson sp. nov.}

Frutex vel arbor usque ad $5 \mathrm{~m}$ vel altiora. Folia late elliptica ad oblanceolata, 1-2 cm longa. Flores c. $15 \mathrm{~mm}$ diametro, sepalis glabratis deciduis. Ovarium 5-loculare. Fructus 6-12 mm diametro persistentes.

HolotyPE: QuEENSLAND: Mt Gillies, about $20 \mathrm{~km}$ SW. of Rathdowney on Mt Lindesay Highway, P.R. Sharp 2438, 18 Oct. 1978 (NSW). ISOTYPE: BRI.

Compact or spreading shrub 1-2 m tall or small tree to $5 \mathrm{~m}$ or more, the bark close and becoming rather scaly and rough; the younger stems at first silkypubescent but soon glabrous, with a pale and thick, conspicuous flange spreading or curving around the stem and up beside the leaf-base, and with branching often, but not invariably at $30^{\circ}$. Leaves aromatic, from almost erect to irregularly spreading, mostly $10-20 \mathrm{~mm}$ long and $2-8 \mathrm{~mm}$ wide, obovateoblanceolate to narrowly or broadly elliptical, usually completely glabrous, the margins flat or slightly recurved, the texture variable and probably dependent on habitat, the apex tapering to a distinct folded, but rarely pungent, point, very variable, the base tapering, rather flat and virtually petiole-less. Flowers white, c. $15 \mathrm{~mm}$ in diameter, single, on modified shoots that are occasionally axillary but mostly at the ends of short several-leaved branches, the new growth, reddish and often dense, produced beyond the flowering region at flowering time. Bracts red-brown, the inner and bracteoles larger, thin and very broad but enclosing only the very young bud. Hypanthium glabrous and rather dark, with conspicuous glands, c. 4-6 $\mathrm{mm}$ long, with the upper part broadly 
expanded, and tapering, sometimes rather abruptly, and the base rounded above a short tapered broad pedicel, the top of the ovary glabrous. Sepals deciduous though occasionally tardily so, very broadly ovate, c. $3 \mathrm{~mm}$ long, usually dark with pale margins, completely glabrous. Petals 6-8 $\mathrm{mm}$ long. Stamens in bundles of c. 7,3-4 mm long, the broad bases of the filaments sometimes tending to form an irregular ring, the anther-cells c. $0.5-0.6 \mathrm{~mm}$ long, parallel, at least for the most part, often rather recurved, variable but usually rather deep, especially the outer part, or with the outer part wide and shallow. Style inset, stout and broad-based, long-tapering to behind a rather large stigma. Ovary 5-locular, each loculus with c. 80 ovules in 8 rows on a large closet-set placenta. Fruit persistent, very variable, $5-12 \mathrm{~mm}$ in diameter, widest at the narrow erect rim, the lower part shallow and broad-based above a very short stalk absent from older fruit, the valves woody, much exserted, before opening forming a depressed dome shorter than or symmetrical with, occasionally somewhat broader than, the base, later spreading but rarely extending far, if at all, beyond the rim, the base often somewhat turbinate. Mature seeds $2-2.5 \mathrm{~mm}$ long, irregularly narrowly linear-cuneiform, curved, striate. Main flowering period: Mostly Sept.-Oct.

DisTRIBUTION: On the mountains of southeastern Queensland and scattered on the tableland escarpment and coastal ranges of New South Wales to the Taree district (Map 7). On rocky summits or ridge-tops, in heath, skeletal soil or rock crevices, on sandstone, granite or volcanic rock.

Selected SPeCIMEnS: QueEnSLAND: Wide Bay: Mt Perry, Keys 583, (NSW). Moreton: Mt Maroon, Gillieatt 184, 8.1964 (BRI), Armstrong 1132 \& Powell, 9.1977 (NSW). New South WALES: North Coast: c. 1.2 km NW. of Mt Banda Banda, Haegi 1585, 9.1978 (NSW); Gloucester Buckets, Coveny NSW 154756, 1.1967 (NSW), Maiden NSW 15039, 9.1897 (NSW 15039).

This species is named for its variability in many characters, especially those of leaf-width and fruit-size, that appear to vary in specimens from the same locality. Narrow-leaved forms may be confused with $L$. polygalifolium subsp. transmontanum and L. novae-angliae in the absence of flowers.

\section{L. oreophilum $J$. Thompson sp. nov.}

Frutex 1-2.5 m altus. Folia elliptica, 1-1.5 cm longa, manifeste glandulosa. Flores 12-20 mm diametro, sepalis glabratis deciduis. Ovarium 5-loculare. Fructus $7-10 \mathrm{~mm}$ diametro persistentes, valvis valde patentis.

HolotYPE: QueENSLAND: Ngungun, Glass House Mountains, Johnson NSW 154760 , 13.6.1951 (NSW).

Shrub usually $1-2.5 \mathrm{~m}$ tall with firm rough bark; the younger stems minutely and often densely hirsute with a flange widest near each node and extending beside the leaf-base, often to form a rim below the node, and with the branching at $30^{\circ}-45^{\circ}$. Leaves divergent with some later spreading, mostly $10-15 \mathrm{~mm}$ long and 2-4 $\mathrm{mm}$ wide, elliptical, at first silky, later becoming rather glabrous and glossy but often with dense hairs at the base, somewhat thick in texture with dense prominent glands, with the apex acute and tending to infold, with a very short, thick, blunt point which is somewhat recurved, and tapering in the lower-part to a petioleless base. Flowers white, c. 12-20 $\mathrm{mm}$ in diameter, occurring singly on modified shoots at the ends of adjacent short or long leafy branches, the new growth pinkish, extending densely rather than vigorously from branch-ends and to some extent from below young fruit. Bracts not seen mature, pale red-brown and scarious, the innermost and bracteoles very broad 
and enveloping at least the rather young bud. Hypanthium glabrous or with dense, very short, crisped hairs, not very dark, but with conspicuous glands, 2.5-4 mm long, the upper part somewhat expanded so that it tapers strongly and rather evenly to the base or to a very short broad pedicel, or is rounded above this region, the top of the ovary glabrous. Sepals deciduous, c. $3 \mathrm{~mm}$ long, almost orbicular, pale and scarious with the centre somewhat darker, completely glabrous. Petals 4-8 mm long. Stamens in bundles of 7-9, c. $5 \mathrm{~mm}$ long, the broad bases of the filaments tending to form an irregular ring at the base, the anther-cells c. $0.5-0.6 \mathrm{~mm}$ long, parallel, at least for the most part, often recurved but not much folded back, rather deep and not opening very wide, the outer edge of the wide outer part flattened. Style inset, though not deeply so, stout and broad-based, with a rather small stigma. Ovary 5-locular, each loculus with c. 80 ovules in 8 rows on a rather large placenta extended at the top. Fruit persistent, c. $7-10 \mathrm{~mm}$ in diameter, widest at the slightly extended and woody rim and below this very shallow above a very short stalk-like base not seen in older fruit, the valves woody and before opening forming a high dome usually c. twice as deep as the base, later spreading wider than the rim with the base of the fruit becoming extremely shallow or virtually flat. Mature seeds c. $3.5 \mathrm{~mm}$ long, very irregularly narrowly linear-cuneiform, curved, striate. Main flowering period: Sept.-Dec.

Distribution: On the Glass House Mountains of southern Queensland (Map 7). On rocky crests and escarpments of volcanic rock, in shallow soil or rock crevices.

SeleCted SPECIMENS: QueENSLAND: Moreton: Ngungun, McKenzie s.n., 12.1979 (BRI); Cruikneck, Goy, 5.1935 (BRI); Mt Tunbubudla, c. 5 km W. of Beerburrum, Clarkson 166, 9.1976 (BRI).

This species is named for its mountain-top habitat.

\section{L. novae-angliae $J$. Thompson sp. nov.}

Frutex usque ad $2 \mathrm{~m}$ altus. Folia valde varie elliptica, $0.5-1.5 \mathrm{~cm}$ longa, interdum pungentia. Flores 10-12 mm diametro, sepalis glabratis deciduis. Ovarium 5-loculare. Fructus minus quam 5 usqui ad plus quam $12 \mathrm{~mm}$ diametro saepe longipersistentes.

HOLOTYPE: New SOUth WaLes: top of Bald Rock Mountain, 15 miles [24 km] north of Tenterfield, E.F. Constable 2074, 31.III.1962 (NSW 66832).

Shrub usually $2 \mathrm{~m}$ or less in height with bark lifting and flaking; the younger stems usually with a close silky pubescence, later becoming glabrous, with a pale and thick flange, widest near the leaf-base and tending to curve around the stem, and with branching at c. $45^{\circ}$. Leaves usually rather dense and erect to narrowly divergent, very variable, 5-15 $\mathrm{mm}$ long, and $1-4(-5) \mathrm{mm}$ wide, irregularly broadly to very narrowly elliptical, often thick with the surface at least somewhat, often much, incurved in cross-section, glabrous and often with conspicuous glands, the apex tapering, acute or acuminate with a short, usually pungent, point, the base tapering, often to a short broad petiole. Flowers white, most $10-12 \mathrm{~mm}$ in diameter, occurring singly on modified shoots at the ends of dense short or long leafy axillary branches, with most new growth extending from the flowering region after flowering. Bracts red-brown and scarious, the inner very broad and concave, sometimes held about the open flower. Hypanthium glabrous or almost so, dark and with conspicuous glands, c. $4 \mathrm{~mm}$ long, with the upper part much expanded and tapering, the lower narrower and rather rounded above a short pedicel, the top of the ovary glabrous. Sepals 
deciduous, scarious, broadly ovate, obtuse, c. $2.5 \mathrm{~mm}$ long, glabrous. Petals c. $5 \mathrm{~mm}$ long. Stamens in bundles of 5-7, 2.5-4 $\mathrm{mm}$ long, the anther-cells c. $0.5 \mathrm{~mm}$ long, parallel, at least for the most part, thickened in the inner part, the outer deep and broad, with the opening rather restricted, recurved and sometimes folding back. Style inset, stout, with a medium-sized stigma; often absent. Ovary 5-locular, each loculus with c. 80 ovules in 8 rows on a large, broad, close placenta; sometimes absent. Fruit often long-persistent and enlarging, very variable in size, from less than 5 to more than $12 \mathrm{~mm}$ in diameter, widest at the scarcely extended rim with the lower part almost hemispherical, the surface soon lifting and later becoming scaly, the valves woody, exserted as a dome rather symmetrical with the base, later spreading, and with the surface lifting and then somewhat broader than the base. Mature seeds $1.5-2 \mathrm{~mm}$ long, narrowly linear-cuneiform, striate. Main flowering period: Oct.-Nov.

Distribution: Widespread on the Northern Tablelands of New South Wales and adjoining parts of the Western Slopes and Queensland, extending into the coastal region only on the escarpment inland from Coffs Harbour (Map 7). In shallow soil associated with rocky, especially granite, outcrops, or in rock crevices.

Selected SPECimens: QueEnsland: Darling Downs: Girraween National Park near Wyberba, Blake 23679, 11.1971 (BRI, NSW). NEW SouTh WALES: North Coast: Wild Cattle Creek, Dorrigo, White 7531, 10.1930 (BRI, NSW). Northern Tablelands: Top of Bald Rock Mtn, 15 miles [24 km] N. of Tenterfield, Thompson 4193, 7.1981 (NSW); Big Spirabo Mtn, 20 miles [32 km] SSE. of Tenterfield, Constable 7068, 8.1966 (NSW); Point Lookout, Dorrigo Plateau, Williams 676, 11.1958 (NSW). North Western Slopes: Pindari Dam, Severn R., 15 miles [24 km] NE. of Bukkulla, Lane NSW 154774, 6.1970 (NSW).

This species is named for the New England region of New South Wales, its major habitat.

The close-set placenta distinguishes fruiting specimens of small-leaved forms of this species from $L$. minutifolium where, in the fruit, the placenta extends into the loculus.

50. L. minutifolium C.T. White, Proc. Roy. Soc. Queensland 57: 26 (1947), quoad Typum.

HOLOTYPE: QueEnSLAND: base of Mt Norman via Wallangarra, Mrs M.S. Clemens, Nov. 1944 (BRI).

SyNONYMY: L. flavescens var. minutifolium F. Muell. ex Benth., Fl. Austral. 3: 105 (1866). Holotype: New South Wales: New England, C. Stuart (K, n.v.). ?Isotype: NSW. L. polygalifolium var. minutifolium (F. Muell. ex Benth.) Domin, Biblioth. Bot. 89: 452 (1928).

Shrub from less than $1 \mathrm{~m}$ to $2 \mathrm{~m}$ or more in height with, as seen on specimens, close or smooth and flaking bark; the younger stems relatively stout and usually appressed-hirsute, with a thick, pale flange, especially near the node, spreading or tending to curve around the stem, and with branching at $45^{\circ}$ but often curving so as to appear at a smaller angle. Leaves usually dense and diverging widely or spreading, mostly $2-4$ but up to $7 \mathrm{~mm}$ long and usually $2 \mathrm{~mm}$ wide, narrowly to broadly obovate, thick, especially near the apex, usually concave and glossy and, for the most part glabrous, with prominent glands, the apex rounded or somewhat acute with an umbo behind, the base gradually tapering, the petiole negligible or very short and rather narrow. Flowers white, usually c. $8 \mathrm{~mm}$ in diameter, single on modified shoots at the ends of short or long leafy 
axillary branches in adjacent axils on adjacent branches, the new growth developing strongly from branch-ends and less so from some flowering shoots after or sometimes during flowering. Bracts mostly small and scarious, the inner and bracteoles very concave and red-brown, enclosing only the very young flattopped bud, all soon shed. Hypanthium glabrous, dark and with rather conspicuous glands, 2-3 mm long, widely expanded at the top and with the lower part tapering to, or somewhat rounded above, a short pedicel, the top of the ovary glabrous. Sepals deciduous, $1.5-2 \mathrm{~mm}$ long, very thin and pale, very obtuse, oblong and glabrous. Petals $2.5-3 \mathrm{~mm}$ long. Stamens in bundles of 3-5, 3-3.5 mm long, with some filaments broad at the extreme base, the anther-cells c. $0.3-0.4 \mathrm{~mm}$ long, tending to separate, occasionally to diverge, very deep, failing to open wide, and somewhat folded back. Style inset, stout with a large stigma. Ovary 5(-7)-locular, each loculus with c. 70-80 ovules in c. 8 rows on a large and somewhat extended placenta. Fruit persistent, 5-7 $\mathrm{mm}$ in diameter, widest near the scarcely extended rim, with the lower part rather hemispherical or wider above a scarcely perceptible stalk, the surface soon lifting and later often flaky, the valves very woody, at first raised to a dome equal to or somewhat shorter than the base, later spreading but seldom, and then scarcely, wider than the rim. Mature seeds c. $2 \mathrm{~mm}$ long, irregularly narrowly linearcuneiform, striate. Main flowering period: Oct.-Nov.

Distribution: On the Northern Tablelands and nearby Western Slopes of New South Wales and in the "Granite Belt" of southern Queensland (Map 7). In swamps and on rocky creek banks, especially in elevated places.

SELECTED SPECIMENS: QUEENSLAND: Darling Downs: Girraween National Park, near Wallangarra towards Mt Norman, Blake 23704, 11.1971 (BRI, NSW). NEW SouTH WALES: Northern Tablelands: Torrington, Boorman NSW 14161, 11.1919 (NSW); Wollomombi to Guy Fawkes, at Point Lookout turnoff, Johnson NSW 17473, 11.1931 (NSW). North Western Slopes: Guyra-Tingha road, 10 miles [16 km] from Tingha, Blakely, McKie \& Youman NSW 143920, 11.1929 (NSW).

The extended top on the placenta distinguishes fruiting material from smallleaved forms of $L$. novae-angliae which have a close-set placenta.

C. T. White included specimens now placed in $L$. novae-angliae and $L$. gregarium in his concept of this species.

\section{L. sejunctum $J$. Thompson sp. nov.}

Frutex 1-1.5 m altus. Folia elliptica ad oblanceolata, 1-2 cm longa, manifeste glandulosa. Flores sepalis tarde deciduis. Ovarium 5-loculare. Fructus c. $8 \mathrm{~mm}$ diametro persistentes, valvis non valde patentis.

Holotype: New SOUTH Wales: Flat Rock Creek on Yalwal road, $3.4 \mathrm{~km} \mathrm{SW}$. of Nowra, $34^{\circ} 54^{\prime} \mathrm{S}, 15^{\circ} 34^{\prime} \mathrm{E}$, alt. $15 \mathrm{~m}, R$. Coveny 10976 \& $T$. James, 30.ix.1981 (NSW). ISOTYPES: AD, BRI, CANB, CBG, HO, K, L, MEL, MO, PERTH.

Shrub 1-1.5 $\mathrm{m}$ tall with close grey bark; the younger stems glabrous or almost so, with a pale, thick and conspicuous, not very wide flange tending to curve about the stem and scarcely extended beside the leaf-base, and with the branching at c. $60^{\circ}$. Leaves somewhat aromatic, at first erect, later diverging, mostly 10-20 mm long and 3-4 mm wide, oblanceolate to elliptical, glabrous, rather thick and with dense prominent glands, the apex usually tapering gradually to a conspicuous, but folded and blunt rather than pungent, point, the base tapering, flat and petioleless. Flowers not seen at maturity but, from traces and fruit, assumed to be on modified shoots in axils and on very short leafless axillary 
branches, occasionally on leafy axillary branches, with the new growth appearing pinkish and extending both from flowers and from branch-ends. Bracts pale red-brown, the innermost and bracteoles (seen about several buds) pale, scarious and very broad and enveloping (as in L. variabile). Hypanthium (seen from one bud, and one old flower) glabrous and dark, with conspicuous glands, c. $2 \mathrm{~mm}$ long, broad above and tapering evenly to above a very short pedicel, the top of the ovary glabrous. Sepals tardily deciduous, c. $2 \mathrm{~mm}$ long, broadly ovate, dark in the centre but with scarious margins, glabrous except for hairs at the top or also on the margins. Petals not seen mature. Stamens in bundles of c. 7 , c. $2 \mathrm{~mm}$ long, the filaments broad in the lower part and fused into bundles at the base, the anther-cells c. $0.5 \mathrm{~mm}$ long, parallel, somewhat recurved and rather deep on the outer part. Style not or scarcely inset, slender apart from a broad base, the style small; sometimes reduced or absent. Ovary 5-locular, each loculus with c. 80 ovules in 8 rows on a rather high, stout, broad but relatively short placenta often somewhat extended at the top; occasionally absent. Fruit persistent, usually c. $8 \mathrm{~mm}$ in diameter but variable in size, widest at the erect or somewhat incurved rim, the lower part shallow and broad-based above a very short stalk absent from older fruit, the valves woody, much exserted before opening and forming a dome approximately equal to the base although with rather variable proportions, on opening extending but rarely much, if at all, beyond the rim, the base somewhat turbinate. Mature seeds c. $2.5 \mathrm{~mm}$ long, irregularly narrowly linear-cuneiform, curved, striate. Main flowering period: not known.

Distribution: Found only in the Nowra district of coastal New South Wales (Map 7). In sandy soil on sandstone.

Specimens examined: New South Wales: Central Coast: summit of Alum Rock, Bomaderry Creek, near Nowra, Rodway NSW 154759, 12.1944 (NSW). South Coast: Flat Rock Creek, 1.6 miles $(2.6 \mathrm{~km}) \mathrm{SW}$. of Nowra on the Yalwal road, Coveny 3989 \& Bisby, 3.1972 (NSW).

This species is named for its separation as to locality from the somewhat similar L. variabile and L. oreophilum.

L. myrtifolium subgroup (spp. 52-64), Map 8.

52. L. rupestre Hook. $f$., Icon. Pl.: t. 308 (1841).

SyNTYPES: TASMANIA: Summit of Mt Wellington and other mountains in Van Diemen's Land, Lawrence, Fraser, R. Gunn $n 295$ (K, n.v.). In NSW there are specimens from Mt Wellington, Gunn 295/1842, dated 28.9.39, 31.1.40 and 30.10.40.

SYNONYMY: L. scoparium var. microphyllum S. Schauer, Linnaea 15: 425 (1841). Holotype: TASmania: in Insula Van-Diemen monte Wellington, A. Cunn. 44, 1819 (?, n.v.).

[L. humifusum A. Cunn. ex Schau., loc. cit., nom. nud.]

L. grandifolium var. compactum F. Muell. in Miq., Ned. Kruidk. Arch. 4: 144 (1859). TYPE: TASMANIA: in montosis 3-4000 pedes altis, $F$. Mueller, s.d. (?U, n.v.).

Shrub rarely more than $1.5 \mathrm{~m}$ in height, usually low-growing and spreading over the surface of boulders, the bark flaky; the younger stems with a long, later short, silky pubescence, rarely glabrous, with an often conspicuous and rather thick and broad flange near the node with a ridge extending below, and close branching, usually at c. $30^{\circ}$, though often curving later. Leaves aromatic, divergent, (2-)5-7(-9) $\mathrm{mm}$ long and usually $2-3 \mathrm{~mm}$ wide, generally broadly to narrowly obovate to elliptical, longest in more sheltered places, often rather 
glossy, thick and usually almost flat, often with prominent glands, glabrous or with some hairs expecially on the margins, occasionally silky-pubescent, the apex broadly acute to obtuse or rounded with the tip usually recurved and thickened behind and somewhat infolded in front, the base tapering to a slender petiole to $1 \mathrm{~mm}$ long. Flowers white, $7-10 \mathrm{~mm}$ in diameter, occurring singly or occasionally 2 together on modified shoots on very short usually few-leaved axillary branches, with pink-tinged new growth extending, mainly from branch-ends during flowering, but after flowering often with a little development in the flowering region. Bracts broad, red-brown and scarious, the inner and bracteoles very broad and enveloping the young bud but shed well before the flower opens. Hypanthium usually glabrous, occasionally with a silky pubescence at the top and base, rarely entirely pubescent, 2-3 $\mathrm{mm}$ long, the upper part broadly expanded, the lower abruptly contracting to a slender pedicel c. $1 \mathrm{~mm}$ long, the top of the ovary glabrous. Sepals deciduous, c. $2 \mathrm{~mm}$ long, broadly ovate to oblong with the apex rounded, scarious and glabrous except for the minutely ciliate margins. Petals $3-3.5 \mathrm{~mm}$ long. Stamens in bundles of $3-5,1.5-2 \mathrm{~mm}$ long, the filaments often very broad in the lower part but scarcely united, the anther-cells $0.3-0.4 \mathrm{~mm}$ long, parallel, and somewhat deeper in the outer part. Style inset, stout with a medium-large stigma. Ovary 5-locular, each loculus with c. 30 ovules in c. 6 rows on a rather large extended placenta. Fruit long-persistent but not much enlarged, usually c. $4-5 \mathrm{~mm}$ in diameter, widest at a rather extended woody rim, the lower part usually hemispherical above a short stalk, the surface lifting and ultimately scaly and gnarled, the valves very woody and, before opening, exserted as a dome that is usually indented in the centre and equal to, or shorter than, the broad part of the base, the valves later spreading, sometimes so as to exceed the width of the rim and depth of the base. Mature seeds c. 2(-2.5) mm long, narrowly linearcuneiform, curved, striate. Main flowering period: Jan.-Feb. (-Mar.).

DiSTRIBUTION: Widespread on mountain-tops in Tasmania (Map 8). Among boulders in exposed places.

Selected specimens: Tasmania: Mt Barrow, Canning 2635, 2.1969 (CBG, NSW); Mt Field National Park, c. 30 m SE. of Sitzmark Ski Lodge, Short 1821, 1.1983 (HO, MEL, NSW); Mt Wellington, Gunn 295/1842, 9.1839,1.1840,10.1840 (NSW); summit of Table Mtn, near Derwent R., Brown, 3.1804; The Pinnacle, Mt Wellington, Garden NSW143916, 1.1949 (HO, NSW).

\section{L. myrtifolium Sieber ex DC., Prodr. 3: 228 (1828).}

Holotype: New South Wales: New Holland, Sieber 314 (G, n.v., photo NSW).

SyNONYMY: L. thymifolium Cunn. in Field, Geogr. Mem. New South Wales (1825), non Hoffmansegg. HolotyPe: New SOUTH WALEs: Macquarie River, A. Cunningham 108, 1822 (K, n.v.).

L. cunninghamii S. Schauer, Linnaea 15: 420 (1841), quoad Typum. HolotYPE: New South Wales: in sylvae palud. Novae Cambriae austral. int., A. Cunningham herb. $n$. $108,1822(\mathrm{~K}, \mathrm{n} . \mathrm{v}$.$) ; there are also elements of L$. multicaule in the protologue of this species.

L. pubescens Lam. var. parviflorum Domin, Biblioth. Bot. 89:453. HOLOTYPE: so auf den Bergen in Victoria (PRC, n.v., but identified from the locality and description).

Slender shrub $1-2(-3) \mathrm{m}$ in height with a close bark forming flaky layers on old plants; the younger stems densely pubescent, with some hairs short, crisped and irregular and others longer and tending to spread, the flange usually narrow and often short, but tending to be thick and extended just below the node, and the branching at $60^{\circ}$. Leaves at first divergent, later often spreading, usually $5-10 \mathrm{~mm}$ long and $2-5 \mathrm{~mm}$ wide and broadly obovate to oblanceolate or 


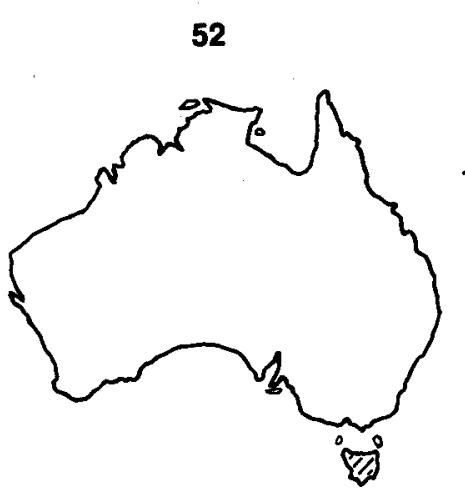

53

54

55

56
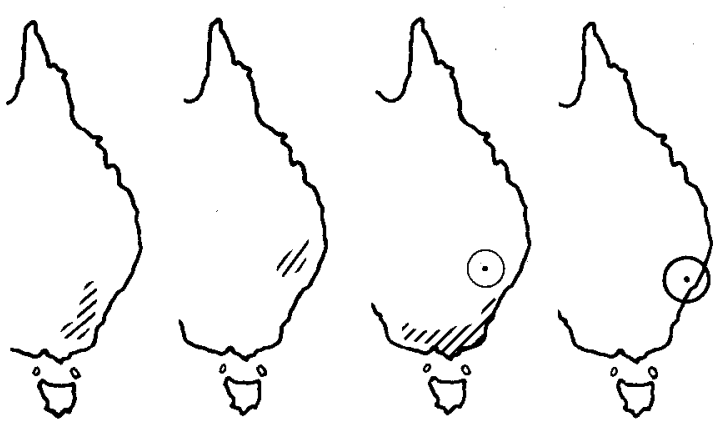

57

58
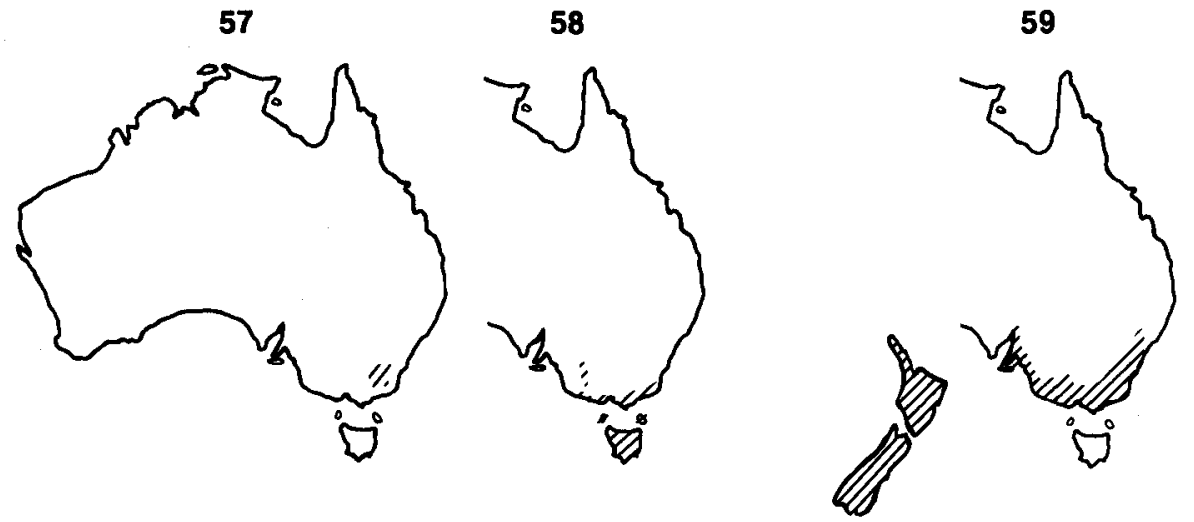

63

64

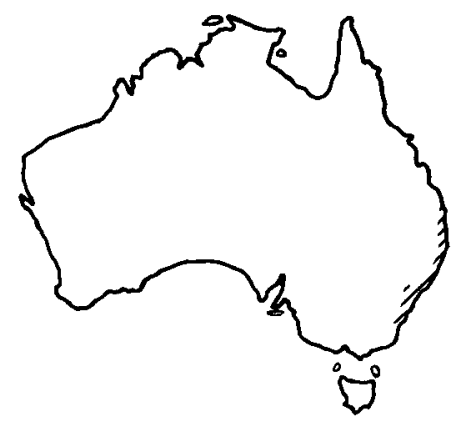

61

62
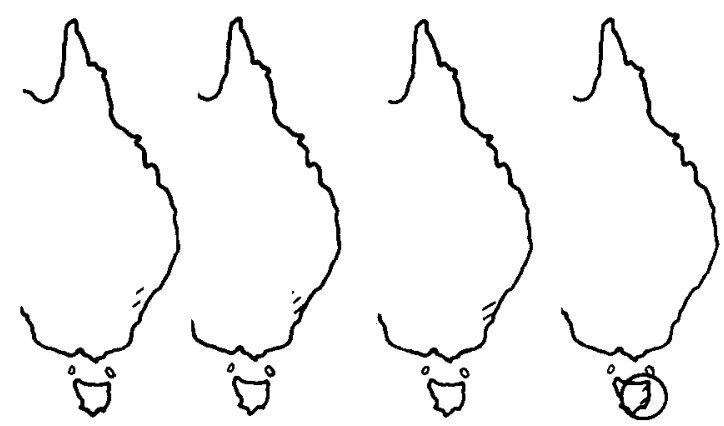

Map 8. Distribution of Group 2: subgroup 3 L. myrtifolium and allies. 52. L. rupestre 53. L. myrtifolium 54. L. gregarium 55. L. obovatum 56. L. argenteum 57. L. micromyrtus 58. L. scoparium 59. L. continentale 60. L. juniperinum 61. L. rupicola 62. L. squarrosum 63. L. rotundifolium 64 . $L$. grandiflorum. 
elliptical, usually pubescent with silky appressed hairs giving a grey-green appearance, occasionally the hairs few or absent; rather thick with prominent glands, the surface flat or slightly incurved in cross-section, the apex acute to broadly rounded with a minute, usually blunt point towards the back, and often somewhat recurved, and frequently infolded, near the tip, the base tapering to a thick petiole usually less than $1 \mathrm{~mm}$ long but occasionally longer. Flowers white, $7-11 \mathrm{~mm}$ in diameter, occurring singly or occasionally 2 together in modified shoots usually at the ends of short few-leaved branches in adjacent leaf-axils, the new growth dense and vigorous at the ends of branches during or after flowering with little development in the flowering region. Bracts rather firmly scarious, red-brown, the inner and bracteoles large and concave, usually shed shortly before the flower opens. Hypanthium densely pubescent with silky appressed or, more frequently, rather spreading hairs, and occasionally with crisped hairs, with obvious glands showing through the pubescence, 2-3 mm long, the upper part somewhat expanded, the lower lobed in cross-section and rather rounded above a distinct pedicel $0.5-1 \mathrm{~mm}$ long, the top of the ovary. glabrous. Sepals deciduous, c. $1.5 \mathrm{~mm}$ long, somewhat scarious, very broadly ovate to oblong or almost orbicular, densely pubescent with short crisped hairs and/or long silky hairs. Petals 3.5-4.5 mm long. Stamens in bundles of $(1-) 3(-5)$, c. $2 \mathrm{~mm}$ long, the anther-cells c. $0.5 \mathrm{~mm}$ long, parallel, slightly or scarcely recurved but often folded back, somewhat deep in the outer part. Style inset, rather stout with a rather small, relative to the style, stigma; often absent. Ovary (4-) 5 (-6)-locular, each loculus with c. 40 ovules in 4 rows on a short, rather high loculus somewhat acute and extended at the top; sometimes absent. Fruit often long-persistent, usually 5-6 $\mathrm{mm}$ in diameter, not extended at the erect rim, the lower part usually almost hemispherical and broad-based above a short stalk, when young with the surface soon lifting, later gnarled, the valves woody and, before opening forming a high dome so that the broad part of the fruit is almost spherical, after opening spreading but seldom much, if at all, beyond the rim. Mature seeds $2-2.5 \mathrm{~mm}$, irregularly narrowly linear-cuneiform, curved, striate. Main flowering period: Dec.-Feb.

Distribution: Widespread on the Central and Southern Tablelands of New South Wales, in adjoining parts of the Western Slopes in the south, and in northeastern Victoria (Map 8). Usually in damp, poorly drained, often rather peaty, sandy soils in woodland, often on the margins of high altitude swamps, occasionally on rocky creek banks.

Selected Specimens: New South Wales: Central Tablelands: Gosling Creek, Canobolas State Forest, 9 miles [14.5 km] S. of Orange, Johnson NSW 25002, 8.1953 (NSW); 18 $\mathrm{km}$ NW. of Taralga, $3 \mathrm{~km}$ from Wombeyan Caves ..., Tyrrel 111 \& Streimann, 8.1978 (CBG, NSW). Southern Tablelands: Murray Gap, A.C.T., Burbidge 6949, 2.1961 (CANB, NSW); Wilsons Valley, Kosciusko National Park, Thompson 2810, 2.1978 (NSW). South Western Slopes: Burrinjuck, Boorman NSW 54765, 2.1911 (NSW). VICTORIA: East Gippsland: Little River, Wulgulmerang, c. 33 miles [53 km] NNE. of Buchan, Melville 3017 \& Wakefield, 1.1953 (NSW). Northeastern Highlands: Mt Buffalo, Eagle Point area, Willis, 2.1963 (MEL, NSW).

This species hybridises with $L$. continentale in eastern and southern parts of its range and with $L$. obovatum in the northern part.

\section{L. gregarium $J$. Thompson sp. nov.}

Frutex c. $2 \mathrm{~m}$ altus. Folia subcrassa late obovata ad oblanceolata pubescentia, $0.5-1 \mathrm{~cm}$ longa. Flores ad $10 \mathrm{~mm}$ diametro, sepalis pubescentibus deciduis. Ovarium 5-loculare. Fructus $4-5 \mathrm{~mm}$ diametro persistentes. 
Holotype: New South Wales: $10 \mathrm{~km}$ from Ebor on Guyra road, J. Thompson 4196, 23.7.1981 (NSW).

Shrub, usually about $2 \mathrm{~m}$ tall, with close bark that (from specimens) appears to be shed at times in fibrous strips or small flakes to leave a smooth surface; the younger stems with a close pubescence, a conspicuous flange usually tending to curve slightly around the stem, and with branching c. $45^{\circ}$ but often narrowing subsequently. Leaves usually crowded and at first rather erect, later more spreading, mostly $5-10 \mathrm{~mm}$ long but occasionally to $15 \mathrm{~mm}$, and usually 2.5-4 mm wide, broadly obovate to oblanceolate, rather thick, with prominent glands and usually closely pubescent with the pubescence of silky hairs on young leaves giving way to short rather crisped hairs, somewhat incurved in cross-section, the apex obtuse to broadly acute, often with a short blunt point, the base tapering to a very short broad petiole. Flowers white, $10 \mathrm{~mm}$ or less in diameter, occurring singly or occasionally 2 together on modified shoots on leafless or few-leaved axillary branches in adjacent axils and on adjacent branches, the new growth extending densely, mostly from branch-ends after flowering. Bracts thin, scarious and pale to red-brown, the inner and bracteoles large and concave but enclosing only the rather small bud, very deciduous. Hypanthium with a dense long, usually crisped pubescence or, occasionally, glabrous, rather dark with rather obvious glands, c. $3 \mathrm{~mm}$ long, the upper part slightly expanded, the lower tapering slightly and then abruptly above a very short pedicel, the top of the ovary glabrous. Sepals deciduous, $1.5-2 \mathrm{~mm}$ long, almost orbicular to obtusely deltoid, rather scarious but densely pubescent. Petals c. 3-4 mm long. Stamens in bundles of 3-5, 1.5-2 mm long, the anthercells, c. $0.5 \mathrm{~mm}$ long, parallel, recurved and often somewhat folded back, deep with the outer part wide. Style inset, broad-based and rather stout, with a rather large stigma; often absent. Ovary (4-) 5-locular, each loculus with c. 60 ovules in 8 rows on a short high extended placenta; sometimes absent. Fruit persistent, variable in size, 4-(5-6)-8 $\mathrm{mm}$ in diameter, widest at the rim, the lower part narrower and, when young, lobed in cross-section and with the surface lifting, later gnarled, the valves woody and before the opening forming a dome, usually depressed in the centre, higher than or approximately equal to the broad part of the base, the whole being broader than deep, after opening the valves spreading but often not as wide as the rim, occasionally wider but still remaining comparable in depth to the round base. Mature seeds c. $2 \mathrm{~mm}$ long, irregularly narrowly linear-cuneiform, curved or sigmoid, striate. Main flowering period: Nov.-Dec.

Distribution: On the Northern Tablelands and Western Slopes of New South Wales and in the "Granite Belt" of Queensland (Map 8). In high-altitude swamps or in rocky places along streambanks.

SELECTED SPECIMENS: QUEENSLAND: Darling Downs: Wallangarra, Boorman NSW 154764, 4.1914 (NSW). NEW SouTH WaLES: Northern Tablelands: Stonehenge, Maiden NSW 154763, 12.1899 (NSW); Hanging Rock near Nundle, Cheel NSW 154762, 4.1926 (NSW). North Western Slopes: Bundulla State Forest, Warrumbungle Ranges, Burrows NSW 154761, 10.1918 (NSW).

This species is named for its tendency to grow in dense stands in swampy areas.

55. L. obovatum Sweet, Fl. Austral.: t. 36 (1827)28).

TYPE: A plant, grown from seed collected by C. Frazer in New South Wales, raised at the nursery of Whitley, Brames and Milne, at Fulham, illustrated by Sweet, loc. cit.

SYNONYMY: L. flavescens var. obovatum (Sweet) F. Muell. ex Benth., Fl. Austral. 3: 104 (1867). 
Dense erect shrub often $2 \mathrm{~m}$ or more in height with close and firm bark; the younger stems with a close appressed pubescence, a flange thick near the node and somewhat broader there, otherwise not very broad or thick but quite conspicuous, and with branching at c. $30^{\circ}$. Leaves aromatic, erect to spreading or even deflexed, $5-20 \mathrm{~mm}$ long and 2 to more than $8 \mathrm{~mm}$ wide, narrowly oblanceolate to very broadly obovate, glabrous or with some appressed pubescence, at least at first, usually rather thick with the margins tending to incurve, or occasionally recurve, the apex usually very broad and retuse, occasionally round and rarely acute with a short pungent point, the base long-tapering to a short or negligible petiole. Flowers white, $8-12 \mathrm{~mm}$ in diameter, occurring singly or occasionally 2 together on modified shoots on very short few-leaved or leaf-less branchlets, in adjacent axils on adjacent branches, the new growth vigorous from the ends of branches, usually but not invariably well beyond the flowering region at flowering, with negligible development from the flowering shoot. Bracts red-brown, broad and scarious, the ultimate and the bracteoles large and enclosing the shortly pointed bud, all readily deciduous. Hypanthium rather dark, and glabrous or with a short irregular pubescence, $2.5-3.5 \mathrm{~mm}$ long, the top very broad, tapering, and the lower part somewhat lobed in cross-section and narrowing to, or somewhat rounded above, a short pedicel, the top of the ovary glabrous. Sepals deciduous, $2-2.5 \mathrm{~mm}$ long, glabrous or with ciliate margins, pale and scarious, broadly ovate to almost orbicular, or oblong. Petals 3-4 mm long. Stamens in bundles of 5-7, 2-2.5 mm long, the anther-cells c. $0.5 \mathrm{~mm}$ long, parallel recurved and folded back to some extent, very broad and deep in the outer edge and with the inner thickened, their opening rather restricted. Style inset, broad-based and tapering, and with the stigma rather large; sometimes absent. Ovary 5-locular, each loculus with c. 60 ovules in 6-8 rows on a large, broad, sometimes somewhat extending placenta; sometimes absent. Fruit persistent, 5-8 $\mathrm{mm}$ in diameter, widest at the scarcely extended rim, the lower part rather shallow and rounded above a very short stalk, the surface occasionally lifting, often flaking, later flaky, the valves woody, at first raised so as to be symmetrical with the surface lifting, and ultimately spreading wide so as to be much wider than the now very shallow base. Mature seeds 2-2.5 mm long, irregularly narrowly linear-cuneiform, curved, striate. Main flowering period: Nov.-Jan.

Distribution: From an isolated occurrence in the Pilliga Scrub at the foot of the Warrumbungle Mountains in New South Wales, through Central and Southern Tableland and Coastal regions to western Victoria (Map 8). Often in swampy places but more frequently among granite or sandstone rocks on the edges of swift-flowing streams.

Selected SPECimens: New South Wales: Central Coast: Springwood, Boorman NSW 154773, 1.1901 (NSW). South Coast: Whipstick Creek near Burragate, Thompson 4257, 3.1982 (NSW). Central Tablelands: Rydal to Fish R. and Sidmouth Valley, Maiden \& Cambage NSW 143930, 4.1909 (NSW). Southern Tablelands: Snowy R., just above Guthega Dam, Thompson 4266, 3.1982 (NSW). North Western Slopes: Warrumbungle Ranges, Forsyth NSW 154772, 10.1899 (NSW). VictOria: East Gippsland: Wangarabelle, Beauglehole 33700, 8.1970 (MEL, NSW), Thompson 4237, 3.1982 (NSW). Western Coastal Plains: Glenelg R., Cherrypool, Henty Highway, Beauglehole 4718, 3.1957 (MEL, NSW).

\section{L. argenteum $J$. Thompson sp. nov.}

Frutex 1-2 m altus. Folia subcrassa obovata-elliptica, $0.5-1.5 \mathrm{~cm}$ longa, junioribus sericeis. Flores $8-12 \mathrm{~mm}$ diametro, sepalis pubescentibus deciduis. Ovarium 5-loculare. Fructus 5-7 mm diametro persistentes. 
Holotype: New South Wales: Upper Gummi Creek (Mt Royal Range), $4200 \mathrm{ft}$ [1280 m] alt., [Upper Manning R.,] R. W. Earp NSW 154771, 27 Jan 1957 (NSW).

Shrub often 1-2 m tall, occasionally up to $7 \mathrm{~m}$, with, as seen from specimens, rather smooth close bark that tends to be shed in strips or flakes; the younger stems with a dense close pubescence, sometimes glabrescent, a conspicuous, spreading flange, broad and thick especially at the node, and branching at $\mathrm{c}$. $45^{\circ}$. Leaves at first diverging only narrowly but soon at least some spreading widely, most 5-15 $\mathrm{mm}$ long and about $1 / 2$ as wide, very broadly obovateelliptical, thick, and almost flat, with somewhat prominent glands, ultimately glabrous or almost so but the young growth grey with silvery pubescence, the apex with an umbo at the back, obtuse, from very broadly rounded to almost acute, the base tapering, usually to a short petiole. Flowers white, c. 8-12 mm in diameter, occurring singly or occasionally 2 together on modified shoots on short, often very short, leafless or few-leaved axillary branches, the new growth dense and vigorous from branch-ends during flowering, i.e. with the flowering region below it, and very limited and later from near the flower. Bracts rather pale, red-brown and scarious, the inner and bracteoles longer, elliptical and concave, enclosing only the very young pointed bud. Hypanthium usually with a few short irregular hairs on the expanded upper part, 2-3 $\mathrm{mm}$ long, somewhat lobed in cross-section, rather dark and glabrous, and very broad above a narrow, densely hairy, pedicel c. $1 \mathrm{~mm}$ long, the top of the ovary glabrous. Sepals deciduous, c. $2 \mathrm{~mm}$ long, broad-ovate and obtuse to almost spherical, pubescent at least in part, the hairs longer and dense at the apex, scarious with wide pale margins. Petals c. 4-5 mm long. Stamens in bundles of c. 5, 2-3 mm long, the anther-cells c. $0.5 \mathrm{~mm}$ long, parallel, rather deep in the inner and wide in the outer part, recurved and tending to fold back. Style inset, broad-based but tapering towards a rather small stigma. Ovary 5-locular, each loculus with c. 40-45 ovules in 6 rows on a high, short broad extending placenta. Fruit rather long-persistent, 5-7 $\mathrm{mm}$ in diameter, widest at the erect rim, the lower part broader than deep, the surface lifting and later becoming scaly, the valves woody and exserted, before opening, to a height almost equal to the depth of the broad part of the base, after opening spreading and becoming wider and higher than the shorter rounded base. Mature seeds c. $2 \mathrm{~mm}$ long, narrowly linear-cuneiform, curved, and striate. Main flowering period: Jan.

Distribution: Endemic on the Barrington Tops of eastern New South Wales, at high altitudes (Map 8). Along watercourses or in swamps, on basaltic soils.

Selected SPECIMENS: New SOUTH Wales: Northern Tablelands: Tubbrabucca, Tomalla Tableland, Earp NSW 154770, 1.1956 (NSW); Barrington Tops, Boorman NSW 154769, 12.1915, Harrison NSW 154768, 1.1925 (NSW), Munro NSW 154766, 1.1953 (NSW), Benson NSW 154767, 12.1981 (NSW).

This species is named for the colour of its young growth.

57. L. micromyrtus Miq., Ned. Kruidk. Arch. 4: 145 (1859).

Holotype: Victoria: Mt Aberdeen, F. Mueller, s.d. (?U, n.v.).

Rather woody spreading shrub from less than 1 to more than $3 \mathrm{~m}$ tall, with (as seen on specimens) rather flaking bark; the younger stems closely pubescent or glabrous and rather stout, with the flange inconspicuous, thick only at the nodes, and usually narrow there, and the branching at c. $60^{\circ}$ or more but usually soon curving so as to appear at a narrower angle. Leaves strongly 
aromatic, erect or diverging, usually (5-) 10-15 $\mathrm{mm}$ long and 5-10 $\mathrm{mm}$ wide, obovate, often very broadly (almost orbicular), rarely narrowly, flat or somewhat recurved, thick in texture and sometimes with prominent glands, usually glabrous but often with pubescent margins, the apex usually broadly rounded with an umbo at the back but occasionally broadly acute with a short blunt point, the base tapering to, or rounded above, a short petiole. Flowers white, $12-15 \mathrm{~mm}$ in diameter, occurring singly, occasionally 2 together in modified shoots at the ends of very short axillary branches in adjacent axils, the new growth extending from branch-ends well beyond the flowering region before flowering with little or none from the flowering area. Bracts red-brown and scarious, broad, the inner and bracteoles large and concave, enclosing the round-topped bud and shed just before it opens. Hypanthium glabrous and dark, with conspicuous glands, 2-4 mm long, with the upper part somewhat expanded and the lower somewhat lobed in cross-section and rounded at the base above a narrow pedicel of variable length $(0-$ c. $1 \mathrm{~mm})$, the top of the ovary glabrous. Sepals deciduous, c. $2.5 \mathrm{~mm}$ long, almost orbicular, pale, scarious and glabrous. Petals c. $5 \mathrm{~mm}$ long. Stamens in bundles of $5(-7)$, $1.5-2.5 \mathrm{~mm}$ long, the anther-cells c. $0.6 \mathrm{~mm}$ long, parallel, only slightly recurved and folded back, the inner part conspicuously thickened, the outer deep and broad. Style well inset, slender, with a medium-sized stigma; often absent. Ovary (4-) 5-locular, each loculus with c. 80 ovules in c. 8 rows on a broad rather high placenta; sometimes absent. Fruits long-persistent and often tending to become submerged in the outer layers of the stem, very variable in size, usually $5-8 \mathrm{~mm}$ in diameter, widest at a somewhat extended rim, the lower part broad and rounded or rather turbinate with the surface lifting, later very gnarled and flaky, the valves very woody, at first raised to about the equivalent of the broad shallow base, later with the surface often raised and smooth, often tardily dehiscent with the open valves often scarcely spreading, occasionally extending beyond the rim. Mature seeds c. $2 \mathrm{~mm}$ long, narrowly linear-cuneiform, curved, and striate. Main flowering period: Jan.-Feb.

Distribution: On the Southern Tablelands of New South Wales and the high mountains of northeastern Victoria (Map 8). On steep windswept rocky slopes in shallow soil or in rock crevices; on granite.

SELECTED SPECIMENS: New SOUTH WALES: Southern Tablelands: summit of Mt Coree, A.C.T., Darbyshire 151, 2.1961 (CANB, NSW); Little Bald Rock Range, Jounama Peaks, Yarrangobilly, de Beuzeville NSW 143927, 9.1922 (NSW); Tinderry Mts, 8 miles [13 $\mathrm{km}]$ E. of Michelago, Briggs NSW 143914, 12.1965 (NSW). VICTORIA: Northeastern Highlands: Pine Mt., c. $90 \mathrm{~km}$ ENE. of Wodonga, Willis, 1.1964 (MEL, NSW); Buffalo Mt, Cambage 3721, 1.1913 (NSW).

58. L. scoparium Forst. \& Forst. f., Char. Gen.: 72, t. 36,figs. f)1 (1776).

LeCtotype: the plate (t. 36) as to figs g-l, fide McVaugh, Taxon 5: 142 (1956).

Synonymy: Melaleuca scoparia (Forst. \& Forst. f.) L.f., Suppl. Pl.: 343 (1781). Philadelphus scoparius (Forst. \& Forst. f.) Sol. ex Aiton var. linifolius Sol. ex Aiton, Hortus Kew. 2: 156 (1789). Melaleuca scoparia var. diosmatifolia Wendl. f. 7 Schrader, Sert. Hannov.: 24, t. 14 (1797). L. scoparium var. linifolium (Sol. ex Aiton) R. Br. ex Aiton, Hortus Kew, ed. 2, 3: 181 (1811). L. linifolium (? Sol. ex Aiton) Dum.-Cours., Bot. Cult., ed. 2, 5: 384 (1811) (This name, not previously used in specific rank, is placed as a variety of $L$. scoparium here and is, therefore, invalid). L. scoparium var. forsteri S. Schauer, Linnaea 15: 425 (1841).

P. scoparius var. myrtifolius Sol. ex Aiton, loc. cit. TYPE: New ZEALAND: herb. Banks (BM, n.v.). M. scoparia var. myrtifolia (Sol. ex Aiton) Wendl. f. \& Schrader, loc. cit. $L$. scoparium var. myrtifolium (Sol. ex Aiton) R. Br. ex Aiton, loc. cit.

$P$. aromaticus Sol. ex Aiton, loc. cit. (a plant with a deciduous calyx). 
L. floribundum Salisb., Prodr.: 349 (1796), nom. illegit. TyPe: New Zealand: herb. Banks (BM, n.v.).

P. floribundus Usteri ex Roemer \& Usteri, Bot. Mag. (Römer \& Usteri) 3: 177, t. 2 (1790). TYPE: a cultivated plant.

L. scoparium var. parvum Kirk, Stud. Fl. New Zealand 158 (1899). TYPE: NEW ZEALAND: near Wellington (?, n.v.).

L. scoparium var. prostratum Kirk, loc. cit. TYPE: NEW ZEALAND: on mountains (?, n.v.).

L. nichollsii (sphalm. nichollii) Dorr. Sm., Gard. Chron., ser. 3, 43: 399 (1908) in obs.; op. cit. 53: 255 (1913). TYPE: ?.

L. scoparium var. nichollii Turrill, Bot. Mag.: t. 8419 (1912). TYPE: ?Bot. Mag. t. 8419. L. scoparium var. eximium B. L. Burtt, Bot. Mag.: t. 9582 (1939-40). TYPE: cultivated from seed collected near Port Arthur, Tasmania, by H. F. Comber, flowering 1935 (?K, n.v.).

Shrub usually c. $2 \mathrm{~m}$ tall but occasionally reaching $4 \mathrm{~m}$ or more, dwarfed in exposed places, the bark usually close and firm, rarely layered; the younger stems with a long fine silky pubescence but usually soon becoming glabrous, with a conspicuous but not usually much extending flange usually curving round the stem, often with a ridge below the node, and with branching usually at $45^{\circ}$. Leaves mostly widely divergent, spreading or even deflexed, variable in size and shape, often with the region or habitat, from less than 7 to more than $20 \mathrm{~mm}$ long, usually $2-6 \mathrm{~mm}$ wide, narrowly to broadly elliptical, or broadly lanceolate or oblanceolate, with those of new shoots usually larger and often silvery pubescent but soon becoming glabrous, firm or thick especially near the tip and most with the margins incurved or infolded especially in the upper part, occasionally flat and usually minutely tuberculate, the apex tapering to an often acuminate pungent point, the base tapering (except in very narrow leaves) somewhat variably to a short often stout-based, but sometimes negligible, petiole. Flowers white or, rarely, pink or red, usually $8-12 \mathrm{~mm}$ in diameter, occasionally larger, occurring singly, rarely (?aberrantly) several on modified shoots on very short leafless or few-leaved, occasionally many-leaved, branches in adjacent axils and on adjacent branches, with the new growth dense from branch-ends after flowering. Bracts broad, scarious and red-brown, the inner and bracteoles larger and enclosing the young bud, most, or all, shed early. Hypanthium glabrous or rarely with a sparse, short, pubescence and usually rather dark, sometimes with obvious glands, 2-3 (-4) $\mathrm{mm}$ long, the upper part widely expanded, the lower rather lobed in cross-section and tapering or somewhat rounded, usually above a distinct pedicel, the top of the ovary glabrous. Sepals deciduous, usually c. $2 \mathrm{~mm}$ long, oblong to broadly deltoid and sometimes extended at the base, scarious and glabrous or with minutely ciliate margins. Petals 4-7mm long. Stamens in bundles of 5-7 (-9), c. $2.5-3.5 \mathrm{~mm}$ long, the filaments broad-based but scarcely joined, anther-cells $0.5-0.7 \mathrm{~mm}$ long, parallel, with a deep outer part but opening wide and thickened, especially the inner part, usually not much if at all recurved but often tending to fold back. Style inset, stout and straight-sided with a large stigma; often reduced or absent. Ovary 5-locular, each loculus with c. 100 ovules in c. 8 rows on a large, broad and thick, somewhat extended placenta; sometimes absent. Fruit longpersistent and enlarging, usually $6-9$, occasionally more than $10 \mathrm{~mm}$ in diameter, widest at the scarcely extended rim, the lower part rounded or broadly rounded, at first above a very short stalk, the surface usually close, the valves very woody, at first exserted as a dome, indented in the centre, symmetrical, or almost so, with the base, later spreading, often not beyond the rim but frequently widely extending, especially on older fruit, so that the base becomes shallow. Mature seeds $2-3.5 \mathrm{~mm}$ long, irregularly narrowly linear-cuneiform or sigmoid, curved, striate. Main flowering period: Oct.-Feb. 
DISTRIBUTION: Scattered on mainland Australia from Mt Imlay on the far south coast of New South Wales to the Grampians in western Victoria and widespread in Tasmania and New Zealand (Map 8). Especially in rocky and/or moist sandy heath but often riparian along swift-flowing streams.

Selected SPECIMENS: New South Wales: South Coast: Mt Imlay near Eden, Boorman NSW 154778, 12.1916 (NSW). VICTORIA: East Gippsland: Upper Genoa., c. 4 miles [6.5 km] E. of Coopracambra Mtn, Melville 2901 \& Wakefield, 1.1953 (NSW). Western Highlands: W. slopes of Mt William, Serra Range, Briggs 2895, 10.1969 (NSW). TASMANIA: Bass Strait, Kents Group, Brown, 12.1803 (NSW); Rocky Cape, Phillips 031234, 11.1965 (CBG, NSW); Richley 12, 10.1975 (HO); $2.5 \mathrm{~km} \mathrm{~N}$. of Coles Bay along the road to Swansea, Short 1911,2.1983 (MEL, NSW); Strahan; near the wharf, Rodway 1531, 10.1933 (NSW); Macquarie heaths, Meschal 5456, 1.1984 (HO). NEw ZEALAND NORTH ISLAND: Whagaroa County, c. 10.5km due W. of Kaeo, Orchard 3597, 10.1972 (NSW); Pinnacles track, Kaueranga Valley, Coromandel, Gardner 395, 1.1973 (NSW). South Island: Upper gorge of R. Waimakariri, Cockayne 5119, 12.1901 (NSW).

This species is very variable with different forms in different districts and habitats. A number of variants have been found in New Zealand where Holocene extension of range has encouraged diversity. The species is widely used in horticulture where cultivatars vary a great deal in size, colour (of both floral and vegetative features) and shape.

\section{L. continentale $J$. Thompson sp. nov.}

Frutex usque ad $2 \mathrm{~m}$ vel altior. Folia lanceolata pungnetia, $(0.5-) 1(-1.5) \mathrm{cm}$ longa. Flores c. $10 \mathrm{~mm}$ diametro, sepalis glabris deciduis. Ovarium 5-loculare. Fructus $6-7 \mathrm{~mm}$ diametro persistentes.

Holotype: New South Wales: Rocky top, Kanangra, J. Thompson 4304, 30.8.1982 (NSW).

SYNONYMY: L. scoparium forma angustifolium Miq., Ned. Kruidk. Arch. 4: 47 (1859). TyPE: SOUTh Australia: Rivoli-bay [Rivoli Bay], F. Mueller, s.d. (U, n.v.).

Straggling slender shrub, occasionally tree-like, 1-2(-4) $\mathrm{m}$ tall, with close firm bark except in very old plants where it may peel in flaky strips; the younger branches pubescent with long, fine, appressed, often persistent hairs, a conspicuous but not very wide flange often curving around the stem, usually somewhat thicker below the node, and with branching often at $45^{\circ}$. Leaves usually spreading but often recurving or deflexed, (5-) $10(-15) \mathrm{mm}$ long and usually 1-3 mm wide, lanceolate (often narrowly) or less frequently oblanceolate, silky on young shoots, and glabrescent or with the long fine pubescence often retained, rather thick and rigid and incurved or infolded, often strongly, in cross-section, especially toward the apex, occasionally flatter and less rigid, the apex long-tapering to a pungent point and almost terete just behind this, the base tapering to a distinct, occasionally indistinct, broad-based often somewhat triquetrous petiole, the margins often minutely tuberculate. Flowers white or, rarely, flushed pink, 6-11, usually c. $10 \mathrm{~mm}$ in diameter, occurring singly, rarely 2 together, on modified shoots on very short leafless or few-leaved axillary branches in adjacent axils on adjacent branches; the new growth often dense and vigorous, occasionally pink, developing from branch-ends, during and after flowering. Bracts broad, red-brown and stiffly scarious; the inner and bracteoles large and enveloping the young bud, shed early, occasionally with a few persisting. Hypanthium usually glabrous rarely with some 
hairs at the base, rather dark coloured,. 2-2.5 $\mathrm{mm}$ long, the upper part expanding widely, the lower rather lobed in cross-section and rounded or almost truncate above a narrow pedicel, the top of the ovary glabrous. Sepals deciduous, usually $1.5 \mathrm{~mm}$ long, ovate-oblong with the apex rounded, glabrous or with ciliate margins, pale and scarious, the base occasionally extending. Petals c. 3-5 mm long. Stamens in bundles of 5 (-7), 1.5-2 $\mathrm{mm}$ long, the filaments sometimes broad in the lower part and tending to join at the base, the anthercells $0.4-0.5 \mathrm{~mm}$ long, parallel, with a deep outer part but opening wide and thickened, not recurving but tending to fold back. Style inset, stout and straight-sided with a large stigma; often reduced or absent. Ovary (4-) 5-locular, each loculus with c. 60 ovules in $6(-8)$ rows on a large, deep and broad, somewhat extended placenta; sometimes absent. Fruit often long-persistent, but usually not enlarging, usually 6-7 $\mathrm{mm}$ in diameter, occasionally larger, widest near the scarcely extended or woody rim, the lower part broad and curved to a somewhat flattened base or to above a short stalk, the surface close and ultimately gnarled, the valves at first exserted to form a sometimes rather flattopped dome usually almost equal to the base, though variable, later expanding, usually so as to slightly exceed the rim. Mature seeds $2-3 \mathrm{~mm}$ long, irregularly narrowly linear-cuneiform or sigmoid, curved, striate. Main flowering period: Oct.-Jan.

DiSTRIBUTION: From central eastern New South Wales to southeastern South Australia (Map 8). In forest or open sandy swampy places.

Selected Specimens: New South Wales: Central Coast: Royal National Park on plateau above Audley, Thompson 2765, 11.1977 (NSW). South Coast: 4 miles [6.5 km] W. of Green Cape, Constable NSW 30435, 10.1954 (NSW). Central Tablelands: 6 km WNW of Mittagong, Thompson 4070, 12.1980 (NSW). Southern Tablelands: NW. side of Black Mtn, Canberra, A.C.T., Pullen 2110, 7.1960 (CANB, NSW). Central Western Slopes: Ulan, Mudgee-Cassilis road, Johnson \& Constable NSW 16228, 8.1950 (NSW). South Western Slopes: 4 miles [6.5 km] SSW. of Carabost, Logan NSW 94784, 12.1966 (NSW). VICTORIA: East Gippsland: $4 \mathrm{~km} \mathrm{SW}$. of Bemm River township along margin of Sydenham Inlet, Haegi 1675, 2.1979 (NSW). Port Phillip: Port Phillip, Luehmann, 1891 (NSW). Coastal Plains: Anglesea, Huggins 61, 2.1983 (MEL, NSW). SoutH Australia: Southern Lofty: near Adelaide, Cleland, 1898 (NSW). Kangaroo Island: mile [0.8 km] E. of Karatta, Phillips 023804, 9.1965 (CBG, NSW). South-eastern: near Mt Compass, Webster 19083, 11.1973 (NSW).

This species is named for its distribution which is (with the exception of Kangaroo Island) limited to the mainland of Australia. This is in contrast to its close relative, $L$. scoparium, which inhabits, for the most part, Tasmania, the Bass Strait Islands and New Zealand. The species are difficult to differentiate as both are extremely variable and form local phenotypically similar variants. Both grow in East Gippsland where each presents a very different aspect. It is possible that a widespread population has been divided by the formation of Bass Strait and that the mainland has subsequently been reinvaded by the southern isolate.

60. L. juniperinum Smith, Trans. Linn. Soc. London 3: 263 (1797).

Holotype: New South Wales: Port Jackson, J. White s.n., herb. Smith 878.17, 1795 (LINN, n.v.; LIVCM, n.v., photo NSW).

SynONYMY: L. scoparium var. juniperinum (Smith) Domin, Biblioth. Bot. 89: 453 (1928).

L. aciculare S. Schauer, Linnaea 15: 429 (1841). L. scoparium var. aciculare (S. Schauer) Domin, loc. cit. SYNTYPES: In Nov. Holl. orientale and sinum Moreton-Bay et in Nova 
Cambria australe, v.s. spont. (?, n.v.). The protologue may include other elements.

L. aciculare var. majus S. Schauer, loc. cit. SyNTYPES: ad sinum Moreton Bay [Queensland], A. Cunningham (a. 1824) and in Nova Cambria australe (?, n.v.).

L. aciculare var. minus S. Schauer, loc. cit. TYPE: QuEENSLAND: ad sinum Moreton Bay, A. Cunningham (1. 1824) (?, n.v.).

Erect, compact, "Broom"-like shrub often 2-3 m tall, with close bark; the younger stems slender, often with a pubescence of long, fine, usually appressed hairs, and a flange not wide but conspicuous especially at the node and tending to curve around the stem, the branching often at $30^{\circ}$ or if at c. $45^{\circ}$ tending to become more erect. Leaves dense, at first almost erect though later often rather spreading, the youngest silvery silky but soon becoming glabrous, usually narrowly elliptical or narrowly lanceolate, from less than 5 to more than $15 \mathrm{~mm}$ long and up to $2 \mathrm{~mm}$ wide (with occasional leaves more), usually rather thick especially near the almost terete apex, and usually almost flat and with some incurving especially in the upper part, the margins often minutely tuberculate, the apex tapering to a pungent point, the base usually little tapering and contracting to a very short, rather triquetrous but sometimes imperceptible petiole. Flowers white, $6-10 \mathrm{~mm}$ in diameter, occurring singly, or rarely 2 together, on modified shoots at the ends of very short usually several-leaved branches in numerous adjacent axils on adjacent branches, the new growth vigorous from branch-ends after, or during, flowering with no development from the flowering region. Bracts broad and concave, red-brown and scarious, the inner and bracteoles enveloping only the very young bud. Hypanthium glabrous or with a short irregular pubescence, 1.5-2 $\mathrm{mm}$ long, the upper part somewhat expanded and tapering, the lower rather lobed in cross section, usually more abruptly tapered to, or narrowly rounded above a pedicel to c. $0.5 \mathrm{~mm}$ long, the top of the ovary glabrous. Sepals deciduous, usually $1.5 \mathrm{~mm}$ long, broadly ovate, obtuse scarious and glabrous. Petals often c. $3.5 \mathrm{~mm}$ long. Stamens in bundles of 5-7, 1-1.5 mm long, the anther-cells c. $0.3 \mathrm{~mm}$ long, parallel, opening widely, and shallow but with a broad and relatively deep outer part. Style inset, rather slender with a very large stigma; often reduced or absent. Ovary 5-locular, each loculus with c. 40 ovules in c. 6 rows on a broad, short, extended placenta; sometimes absent. Fruit rather long-persistent but not much enlarged, rarely more than $7 \mathrm{~mm}$ in diameter, often smaller, the rim narrow but woody, below this the base somewhat tapered or shallowly rounded and its surface close, the valves woody, exserted, at first as a rather flat-topped lobed dome, depressed in the centre and varying from larger to smaller than the base, later expanding and spreading, often so as to equal or exceed the rim. Mature seeds c. $2 \mathrm{~mm}$ long, irregularly narrowly linear-cuneiform, striate. Main flowering period: irregular, mostly Nov.-Dec.

DisTRIBUTION: In coastal eastern Australia from Fraser Island, Queensland, to Ulladulla in New South Wales, extending inland to the Blue Mountains of New South Wales and the northern edge of the Southern Tablelands (Map 8). In swamps on sandy soils and on sandstone escarpments.

Selected SPECIMENS: QueEnSLAND: Wide Bay: Fraser Is., Hubbard 4590/A, 10.1930 (NSW). Moreton: Broadwater, near Brisbane, Hubbard 4334, 10.1930 (NSW). NEW South Wales: North Coast: Lighthouse Beach area S. of Port Macquarie, Pullen 4261, 1.1967 (CANB, NSW). Central Coast: Port Jackson, Brown, 1803-5 (NSW). South Coast: Dampier State Forest, c. $25 \mathrm{~km}$ W. of Moruya, Pullen 4946, 6.1973 (CANB, NSW). Central Tablelands: Blackheath, Constable NSW 5276, 2.1948 (NSW). Southern Tablelands: Mt Budawang, Rodway 3065, 1.1940 (NSW). 
Most authors have included $L$. continentale in their concept of $L$. juniperinum. These species are similar and some specimens are hard to place, but whether these represent hybrids between the species where their ranges adjoin, a merging of forms to indicate no distinction at specific level between the taxa, or a local modification of one to resemble the other, requires further study.

\section{L. rupicola $J$. Thompson sp. nov.}

Frutex plerumque minus quam $1 \mathrm{~mm}$ altus. Folia anguste lanceolata pungentia, 1-2 mm longa. Flores 10-12 mm diametro, sepalis glabris deciduis. Ovarium 5-loculare. Fructus 6-10 mm diametro persistentes.

Holotypye: New South Wales: Nellies Glen, 1 mile [1.6 km] W. of Blackheath, 3300 ft $[1000 \mathrm{~m}], E$. F. Constable NSW 42755, 16.10 .1957 (NSW).

Robust but low-growing shrub usually $1 \mathrm{~m}$ or less in height, with close and firm bark, the younger stems rather stout, with a long, appressed pubescence at least at first, and a conspicuous and not very wide flange, wider and thicker near the node, extended rather than curving around the stem, the branching at $45^{\circ}-60^{\circ}$. Leaves mostly erect to narrowly divergent, at least at first, and crowded, narrow-lanceolate, c. 10-20 mm long and 1-3 mm wide, glabrescent, and often thick in texture, especially near the apex, the apex long-tapering to a pungent point, the base more gradually tapering, broad, rather triquetrous and petioleless, the margins often minutely tuberculate. Flowers white, 10-12 mm in diameter, single on modified shoots at the ends of very short but usually several-leaved axillary branches in adjacent axils on adjacent branches, the new growth from branch-ends during flowering. Bracts broad, red-brown and scarious, the inner larger and enveloping the young bud, but shed early. Hypanthium glabrous, rather dark and often with conspicuous glands, c. $3 \mathrm{~mm}$ long, the upper part not much expanded, the lower usually little tapering and usually rather broadly rounded above a short narrow pedicel, the top of the ovary glabrous. Sepals deciduous, c. $2 \mathrm{~mm}$ long, rather pale, especially on the margins, and scarious, broadly ovate to almost orbicular, glabrous. Petals c. $5 \mathrm{~mm}$ long. Stamens in bundles of 5-7, c. 1.5-3 mm long, the filaments not or scarcely joined, the anther-cells c. $0.7 \mathrm{~mm}$ long, parallel, deep in the outer part but opening wide, thickened but rather flat and shallow, not recurved but tending to fold back. Style well inset, stout and straight with a very large stigma; often undeveloped. Ovary 5-locular, each loculus with c. 80 ovules in c. 8 irregular rows on a large, deep and rather extended placenta; sometimes absent. Fruit long-persistent, $6-10 \mathrm{~mm}$ in diameter, widest at the erect or spreading and rather woody rim, the lower part usually almost hemispherical with a stalk occasionally tending to persist a while, the surface sometimes tending to lift in large flakes but mostly close, ultimately gnarled, the valves at first not much exserted, the dome wide and shallow but the fruit often tardily opening and then the dome often raised to about the depth of the base, the open fruit with the valves ultimately spreading well beyond the rim and much deeper than the then-shallow base. Mature seeds c. $2 \mathrm{~mm}$ long, irregularly linear-cuneiform, curved, striate. Main flowering periods: Mar.-May and Sept.-Oct.

DiSTRIBUTION: In central eastern New South Wales (Map 8). Associated with high sandstone cliffs and escarpments.

Selected SPecimens: New South Wales: Central Coast: Kangaroo Valley, Cheel NSW 154779, (NSW). Central Tablelands: $2 \mathrm{~km}$ SW. of Glen Davis, Coveny 9450 \& Telford, 5.1977 (NSW); Berrima, Maiden NSW 154780, 9.1901 (NSW). 
This species is named for its habitat; the epithet, being a latin substantive in opposition, does not agree in gender-ending with the generic name.

62. L. squarrosum Gaertner, Fruct. Sem. Pl. 1: 174, t. 35, fig. 3 (1788); B.L. Burtt, Bot. Mag., under t. 9582 (1939).

TYPE: The plate accompanying the description, based on a specimen in the Banksian herbarium: New South Wales, Banks and Solander, 1770 (BM, dupl. NSW).

SYNONYMY: L. scoparium var. squarrosum Dum. - Cours., Bot. Cult., ed. 2. 5:384 (1811). L. scoparium var. vulgare Domin, Biblioth. Bot. 89: 452 (1928).

L. persiciflorum Reichb., Iconogr. Bot. Exot. 3: 8, t. 220 (1830).

L. baccatum var. roseum S. Schauer, Linnaea 15: 429 (1841). TYPE: probably the plate, t. 220 (n.v.).

L. scoparium var. grandiflorum Hook., Bot. Mag.: t. 3419 (1835). TYPE: cultivated at Kew from seed collected at Port Jackson in 1817.

Rather open woody shrub of somewhat variable habit, from less than 1 to more than $4 \mathrm{~m}$ tall with close firm bark; the younger stems often rather stout, with a silky pubescence of long fine hairs but soon becoming glabrous, with a conspicuous, usually thick and often spreading flange, especially near the nodes, and with branching at c. $45^{\circ}$. Leaves usually widely divergent, spreading or deflexed, glabrescent, very variable within and between plants, mostly 5-15 $\mathrm{mm}$ long and $2-5 \mathrm{~mm}$ wide, usually broadly elliptical to broadly ovatelanceolate, occasionally narrower, rarely almost orbicular, usually thick in texture with the, often minutely tuberculate, margins incurved to inrolled or folded, especially near the apex, the apex channelled or terete and tapering to a pungent point, the base tapering to a short broad-based but often negligible petiole. Flowers white or pink, the diameter varying from less than 10 to more than $20 \mathrm{~mm}$, occurring singly on modified shoots on very short, leafless or few-leaved axillary branches in adjacent axils on adjacent branches, the new growth vigorous from the ends of branches of a previous season's flowering. Bracts very broad, thinly scarious and dark red-brown, the inner and bracteoles very large and concave, enclosing large buds and often retained almost until the flower opens. Hypanthium glabrous, dark and often with conspicuous glands, 2.5-4 mm long, the upper part at most slightly spreading, the lower almost straight-sided and broad-based, lacking a pedicel, the top of the ovary glabrous. Sepals deciduous, 2-3 or more $\mathrm{mm}$ in length, broadly ovate and extended at the base, rather pale, scarious and glabrous. Petals 3-7 $\mathrm{mm}$ or more in length. Stamens in bundles of 7-9, usually c. 3-4 $\mathrm{mm}$ long, the anther-cells c. $0.7(-0.8) \mathrm{mm}$ long, parallel, deep in the outer part but opening wide and thickened, usually not much recurved but tending to fold back. Style inset, very stout with a very large stigma; often incompletely developed or lacking. Ovary 5-locular, each loculus with c. 80 to 120 ovules in 8-12 irregular rows on a large, broad and deep, somewhat extended placenta; sometimes absent. Fruit long-persistent, rarely less than $8 \mathrm{~mm}$, often $12 \mathrm{~mm}$ or more, in diameter, widest at the narrow woody rim, the lower part deeply or shallowly rounded, often rather flat-based, the valves very woody, forming an often-flattened dome variously exserted in proportion to the base, and on older fruit often large and wider than the base. Mature seeds 3-4 mm long, irregularly linear-cuneiform, striate. Main flowering period: irregular but often Mar.-Apr.

DiSTRIBUTION: In coastal and adjacent tableland areas of central eastern New South Wales (Map 8). Mostly on skeletal sandstone soils. 
Selected specimens: New South Wales: Central Coast: Berowra, Boorman NSW 14159, 3.1918 (NSW); Royal National Park near Governor Game Lookout, Coveny 7303, 12.1975 (NSW). South Coast: Junction of Point Perpendicular and Currarong roads, Currarong, Coveny 10953 \& James, 9.1981 (NSW). Central Tablelands: Boronia Point, Mt Wilson, Johnson \& Constable NSW 19182, 7.1951 (NSW). Southern Tablelands: Corang Trig., Northern Budawang Range, Olsen 993, 2.1969 (NSW).

63. L. rotundifolium (Maiden \& Betche) F. Rodway ex Cheel, J. \& Proc. Roy. Soc. New South Wales 53: 122 (1919).

BASIONYM: L. scoparium Forst. \& Forst. f. var. rotundifolium Maiden \& Betche, Proc. Linn. Soc. New South Wales 25: 101 (1900).

HolotyPE: New South Wales: Tallwong, [south of Shoalhaven River,] $W$. Forsyth NSW 154775, 1.1900 (NSW).

Shrub from less than 1 to $2 \mathrm{~m}$ or more in height with close and ultimately gnarled bark; the younger stems stout, with a dense pubescence of short ascending to recurved hairs and, at first, some long silky hairs, and with a short dense spreading pubescence persisting, without a perceptible flange or with a flange seen only as a thickening below each node, and with branching at $45^{\circ}-60^{\circ}$. Leaves usually somewhat spreading or recurved, mostly 4-7 mm long and as wide, in general orbicular but sometimes longer than broad or broader than long, glabrous or with some minute pubescence, usually rather thick and incurved in cross-section, or incurved top and bottom and somewhat recurved between, the apex rounded, acute or acuminate, usually infolded, and strongly recurved with a short, usually blunt, but occasionally somewhat pungent point, the base tapering, rounded or somewhat cordate above a distinct pubescent petiole to $1 \mathrm{~mm}$ or more in length. Flowers white to somewhat purplish pink, to more than $30 \mathrm{~mm}$ in diameter, occurring singly on modified shoots at the ends of many-leaved adjacent axillary branchlets, with the new growth, often coloured-tipped, extending vigorously from branch-ends during flowering and some development from flowering shoots or later branches after flowering. Bracts very broad and concave, light to dark red-brown, the inner and bracteoles larger and darker and often enveloping the almost mature bud. Hypanthium glabrous or with an appressed pubescence at the base and top, rarely with a dense silky pubescence all over, 3-6 $\mathrm{mm}$ long, the upper part spreading widely, the lower narrower and usually rounded, often above a short pedicel, the top of the ovary glabrous. Sepals deciduous, broadly ovate to oblong, c. 3-4 mm long, the apex acute or rounded but usually incurved so as to appear acute, glabrous except for a tuft of hairs near the apex or, occasionally, silky-pubescent, and scarious with pale margins. Petals c. 8-12 mm long. Stamens in bundles of c. 9, 4-6 mm long, the filaments with their extreme bases broad but scarcely joined, the anther-cells c. $0.7 \mathrm{~mm}$ long, parallel, often, but not always, recurved, opening wide to show dark inner and outer thickening. Style not or scarcely inset, very stout with a large stigma; often absent. Ovary 5-locular, each loculus with c. 80 ovules in 8 rows on a large broad and relatively short, rather high and close (but with the tip extended) placenta; sometimes absent. Fruit long-persistent, usually $8-12(-15) \mathrm{mm}$ in diameter, widest near the slightly woody but little-extended rim, the base usually almost hemispherical but occasionally shallower and broader and occasionally with a very short stalk, the valves very woody, exserted at first so as to be more or less symmetrical with the base, after opening often not at first spreading widely at the apex, but tearing the base of the style as they part, later often somewhat wider than the rim. Mature seeds 4-5 $\mathrm{mm}$ long, irregularly narrowly linearcuneiform, striate. Main flowering period: Oct.-Dec. 
Distribution: On the tableland escarpment of central eastern New South Wales southward of Sydney, and extending to the coast near Jervis Bay (Map 8). Usually in skeletal soils on sandstone.

Selected Specimens: New South Wales: Central Coast: plateau edge above Jamberoo Pass, SE. of Robertson, Pullen 4054, 4.1961 (CANB; NSW). South Coast: E. approaches to Pigeon House Range ..., Corrick 7030, 10.1985 (MEL, NSW). Central Tablelands; Gold Gully, Penrose, Blakely et al. NSW 14175, 10.1939 (NSW). Southern Tablelands: Nowra road, 4 miles [6.5 km] E. of Nerriga, Adams 1462, 10.1965 (CANB, NSW).

\section{L. grandiflorum Lodd., Bot. Cab.: t 514 (1821).}

TYPE: Native of Van Diemen's Land. A cultivate plant represented by the above illustration.

SYNONYMY: L. flavescens var. grandiflorum (Lodd.) Benth., Fl. Austral. 3: 105 (1867).

L. nobile F. Muell. ex Miq., Ned. Kruidk. Arch. 4: 145 (1859). Type: TaSmania: Stuart, s.d. (? MEL or $U$, n.v.).

L. rodwayanum Summerh. \& Comber, in Comber Field Notes Tasman. P1. 1929-30: 55 (1930), Gard. Chron. ser. 3, 100: 176 (1936). HolOTYPE: TASMANIA: Coles Bay, east of Swansea, at Hazards, $300 \mathrm{~m}$ alt., April 20, 1930, Comber 2322 (K, n.v.).

Much-branched shrub 1.5 to $5 \mathrm{~m}$ or more in height with, as seen on specimens, rough and close bark; the younger stems with a rather stiff white shining, mostly appressed, pubescence with a few curled hairs, and a flange inconspicuous, narrow and somewhat thick, and seen only near the node, the branching at c. $45^{\circ}$. Leaves at first rather erect, later diverging, with some spreading or deflexed, (5-) 10-15 (-18) $\mathrm{mm}$ long and (2-) 4-8 $\mathrm{mm}$ wide, narrowly to broadly obovate or elliptical, thick, greyish-green, often with a dense appressed pubescence and rather prominent glands, almost flat but tending to infold near the apex, which is obtuse or very shortly acute or retuse, often with a minute recurved blunt point, the base tapering to a short, broad petiole and often slightly twisted. Flowers white (? or pink), c. $20 \mathrm{~mm}$ in diameter, occurring singly on modified shoots at the ends of very short to long leafy branches, with the new growth developing densely and often vigorously from branch-ends and to a lesser extent from the flowering shoot during and after flowering. Bracts red-brown and scarious but not seen about large buds. Hypanthium rather dark and wrinkled, glabrous or with a short pubescence on the base, c. $3 \mathrm{~mm}$ long, the upper part broadly expanded and tapering, the lower tapering to a pedicel c. $1 \mathrm{~mm}$ long; the top of the ovary glabrous. Sepals deciduous, $2.5-3.5 \mathrm{~mm}$ long, broadly ovate to orbicular, obtuse, dark with the margins pale glabrous or with some minute hairs especially near the top, and with densely ciliate margins. Petals c. $8 \mathrm{~mm}$ long. Stamens in bundles of c. 7, 4-5 mm long, with some filaments broad-based but only just or scarcely joined, the anther-cells c. $0.6 \mathrm{~mm}$ long, parallel, rather recurved with thickening of the inner part and some broadening of the outer. Style scarcely inset, rather stout, with a mediumsized stigma; often absent. Ovary 5-locular, each loculus with c. 60 ovules in 6 rows from a very high, sometimes small, close-set placenta; sometimes absent. Fruit long-persistent and tending to enlarge, $9-12 \mathrm{~mm}$ in diameter, widest at the very narrow but rather woody rim, scarcely narrower below, the base usually almost hemispherical and sessile, its surface lifting or flaking and ultimately rather smooth, the valves very woody, forming a shallow, rather flattopped dome much shorter than the base, opening tardily and scarcely expanding. Mature seeds c. $4 \mathrm{~mm}$ long, irregularly linear-cuneiform, striate. Main flowering period: ?Feb. (could be out of season flowers)-Apr. 
DisTRIBUTION: Endemic in eastern Tasmania, mostly on and near the Freycinet Peninsula (Map 8). On granite rocks.

SElected SPECIMENS: TASMANiA: 5 miles [8 km] N. of Cranbrook near Tasman Highway, Himson, 2. 1970 (NSW); Mt Amos, Whaite 2671, 12.1962 (NSW); Cape Degerando, Olsen 129, 1.1967 (HO, NSW); Cape Hauy, Tasman Peninsula, Kantvillas \& Jarman 16, 11. 1979 (HO).

L. lanigerum subgroup (spp. 65-79), Map 9.

65. L. deuense $J$. Thompson sp. nov.

Frutex. Folia elliptica usque ad c. $3 \mathrm{~cm}$ longa. Flores c. $15 \mathrm{~mm}$ diametro, sepalis pubescentibus tarde deciduis. Ovarium 5-loculare. Fructus c. 8-10 mm diametro, vix cogniti.

Holotype: New South Wales: $35^{\circ} 55^{\prime} \mathrm{S}, 149^{\circ} 54^{\prime} \mathrm{E}$, alt. $450 \mathrm{~m}$, c. $2 \mathrm{~km} \mathrm{~N}$. of Coondella Trig., Deua National Park, P. Gilmour 4139, 15 Feb. 1984 (NSW). IsOTYPES: CBG, MEL.

Leafy densely branched shrub with, as seen from specimens, rough close bark; the younger stems numerous and relatively stout, pubescent, without a conspicuous-flange but broad below each node and grooved beside it, branching at c. $45^{\circ}$ Leaves divergent, rather variable in size to c. $30 \mathrm{~mm}$ long and c. $6 \mathrm{~mm}$ wide, elliptical, recurved at the margins with the upper surface rather glossy and the lower with a dense, close, short and tightly crisped pubescence, the somewhat infolded apex with an acute, often strongly recurved, stout, sometimes rather pungent, point, the base tapering with the conspicuous midrib thick near the distinct pubescent petiole. Flowers white, c. $15 \mathrm{~mm}$ in diameter, occurring singly or 2 together on modified shoots at the ends of short severalleaved branches, the terminal bud developing during or soon after flowering. Bracts red-brown, but not seen about large buds. Hypanthium with a dense, short, crisped pubescence and often also with some fine straight hairs, c. $4 \mathrm{~mm}$ long, the upper part broadly expanded and the lower shortly, broadly, rounded or tapering above a distinct, stout, pedicel $1 \mathrm{~mm}$ or more in length, the top of the ovary glabrous. Sepals persistent but often shed from young fruit, 3-4 mm long, deltoid, sometimes longer than broad, the tip broadly acute, occasionally rather hooded, densely pubescent. Petals c. 7-8 mm long. Stamens in bundles of $7-9$, c. $4 \mathrm{~mm}$ long, (and free,) the anther-cells c. $0.7 \mathrm{~mm}$ long, parallel, not much folded or recurved, and opening wide to show considerable thickening. Style inset, stout with a stout base, the stigma not large. Ovary 5-locular, each loculus with $60-80$ ovules in 6-8 rows on a broad, high and rather tilted placenta. Fruit (few seen) probably rather variably persistent, c. $8-10 \mathrm{~mm}$ in diameter, widest at the somewhat extended rim, the base deep and rounded above a short stout stalk, the surface rather close and wrinkled, the valves woody, forming a very shallow dome with a central small depression, appearing to open tardily and scarcely expanding. Mature seeds $3 \mathrm{~mm}$ long, narrowly linear-cuneiform, striate. Main flowering period: unknown.

DISTRIBUTION: Known only from a restricted area in the mountains behind Moruya on the South Coast of New South Wales (Map 9). On a rocky rhyolitic ridge.

Other specimens examined: New South Wales: South Coast: Deua National Park, Boland 1988, 5.1984 (FRI, NSW), 2030, 6.1984 (NSW). 
This species is named for the region of its collection near the Deua River that forms part of the headwaters of the Moruya River.

\section{L. grandifolium Smith, Trans. Linn. Soc. London 6: 299 (1802).}

Holotype: New South Wales: Port Jackson, J. White per A.B. Lambert, herb. Smith 878.10, 1795 (LINN, n.v.; LIVCM, n.v., photo NSW).

SYNONYMY: L. lanigerum var. grandifolium (Smith) Hook. f., Fl. Tasman.: 139 (1856).

L. pubescens var. grandifolium (Smith) Domin, Biblioth. Bot. 89: 453 (1928).

L. subargenteum Gand., Bull. Soc. Bot. France 65: 26 (1918).

HOLOTYPE: VICTORIA: near Harrietville, Audas 6.1910 (LY, n.v., photo NSW).

Shrub c. $1.5 \mathrm{~m}$ or more in height, or small tree to more than $6 \mathrm{~m}$, with smooth exfoliating bark that tends to remain about the stems; the younger stems stout and at first densely villous, later closely pubescent, with the flange seen only as a thickened area below each node, and the branching at $45^{\circ}$ or, especially in riparian forms, $30^{\circ}$ or less. Leaves erect to widely divergent, usually 10 to more than $30 \mathrm{~mm}$ long and c. 3-7 $\mathrm{mm}$ wide, oblong or oval with the upper surface glossy and the lower felted, or, in riparian forms, narrowly elliptical or obovate with the lower surface glabrous, often intermediate in these characters, the margins recurved or flat, the apex tapering to an, often conspicuous, pungent point, the base broadly or narrowly tapering to a distinct short petiole. Flowers (12-) $15(-18) \mathrm{mm}$ or more in diameter, white, single on modified shoots at the ends of, often densely, leafy side-branches, the new growth, often very silverypubescent, extending from beyond the flowers after flowering. Bracts very broad, stiff and pale yellow-brown, the inner and bracteoles from very broadly obtuse to tapering, and approximately equal, soon allowing the bud to protrude but often held about the flower. Hypanthium densely villous or occasionally with an appressed silky pubescence, usually 3-5 $\mathrm{mm}$ long, the upper part somewhat expanded, the lower tapering to or rounded above the base or with a very short pedicel, the top of the ovary glabrous. Sepals persistent, 3-4 mm long, ovate-deltoid, densely long-pubescent, villous or appressed-pubescent, and pale, with the tip infolded and hooded. Petals c. 4-7 mm long. Stamens in bundles of 7-9, c. $3.5 \mathrm{~mm}$ long, the anther-cells c. $(0.5-) 0.7 \mathrm{~mm}$ long, parallel, recurved but not much folded back, very much thickened and opening wide but the outer part deep and often broad. Style well inset; often stout, at least at the base, with a medium-sized stigma. Ovary 5-locular, each loculus with 50-60 ovules in c. 6 rows on a large, close, somewhat inset placenta. Fruit longpersistent, $8-10 \mathrm{~mm}$ in diameter, the rim slightly or scarcely extended, the lower part rounded and often very broad-based, the surface lifting and becoming very flaky, the valves very woody and forming a rather low, centrally depressed dome, on opening the surface often lifting and the valves raised a little further, and spreading usually so as ultimately to exceed the base in width. Mature seeds c. 2-2.5 mm long, narrowly linear-cuneiform, curved, striate. Main flowering period: Oct.-Jan.

Distribution: From the Sydney district of coastal New South Wales through the Central and Southern Tablelands to northeastern Victoria (Map 9). In sandy swamps and along watercourses.

SElected SPECIMENS: New South Wales: Central Coast: banks of the River Grose, Brown, 1804-1805 (NSW). Central Tablelands: 11/2 km N. of Cherry Tree Hill on Ilford road, K. Wilson $2429 \&$ Waterhouse, 8.1979 (NSW); on banks of river at Fitzroy Falls, Rodway 230, 11.1920 (NSW). Southern Tablelands: Big Badja Mountain, c. $40 \mathrm{~km} \mathrm{NE}$. of Cooma, Pullen 8544, 10.1973 (CANB, NSW); Maclaughlin R., SE. of Nimmitabel, Salasoo 2061, 1.1961 (NSW). VICTORIA: Eastern Highlands: The Playgrounds, $2.5 \mathrm{~km}$ 

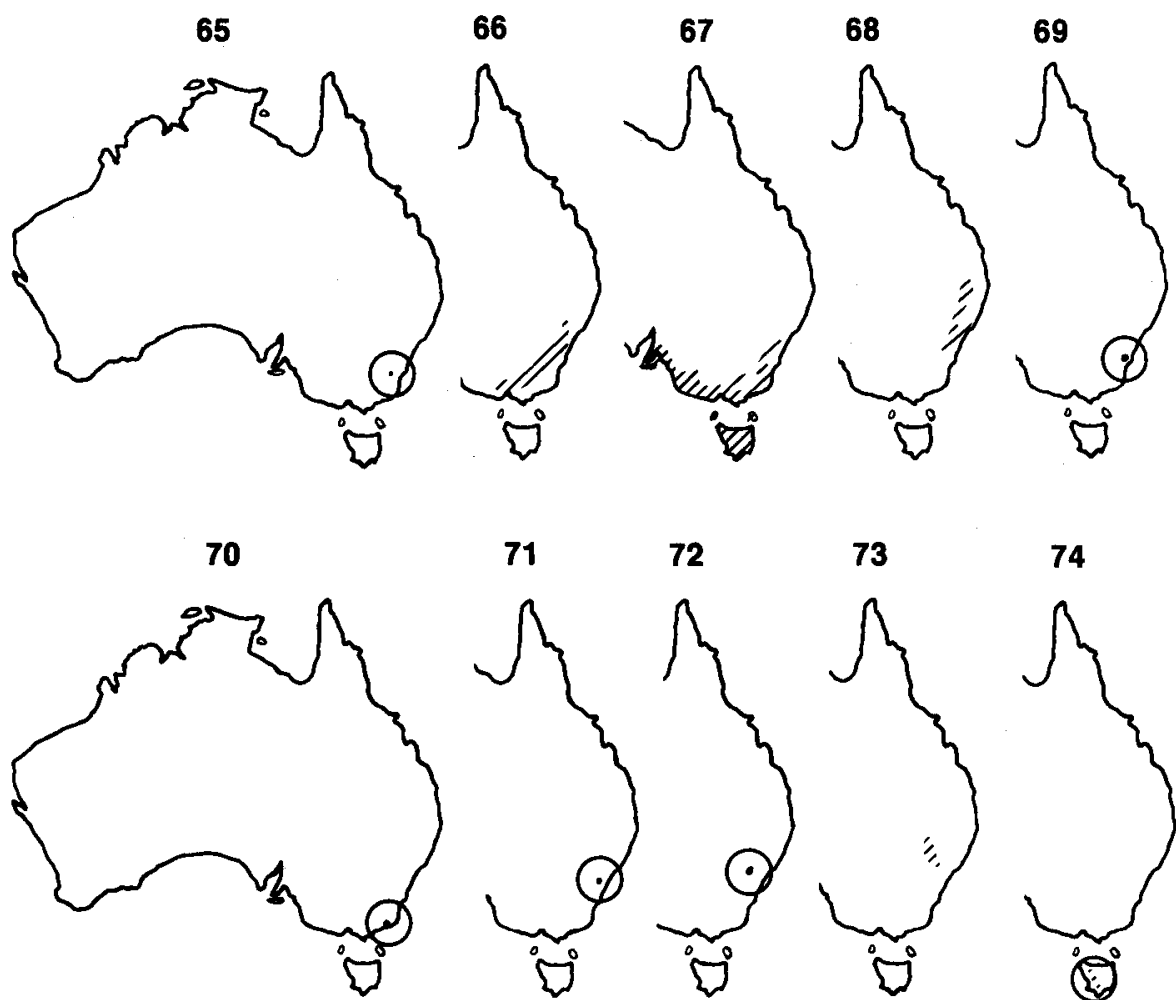

71

72
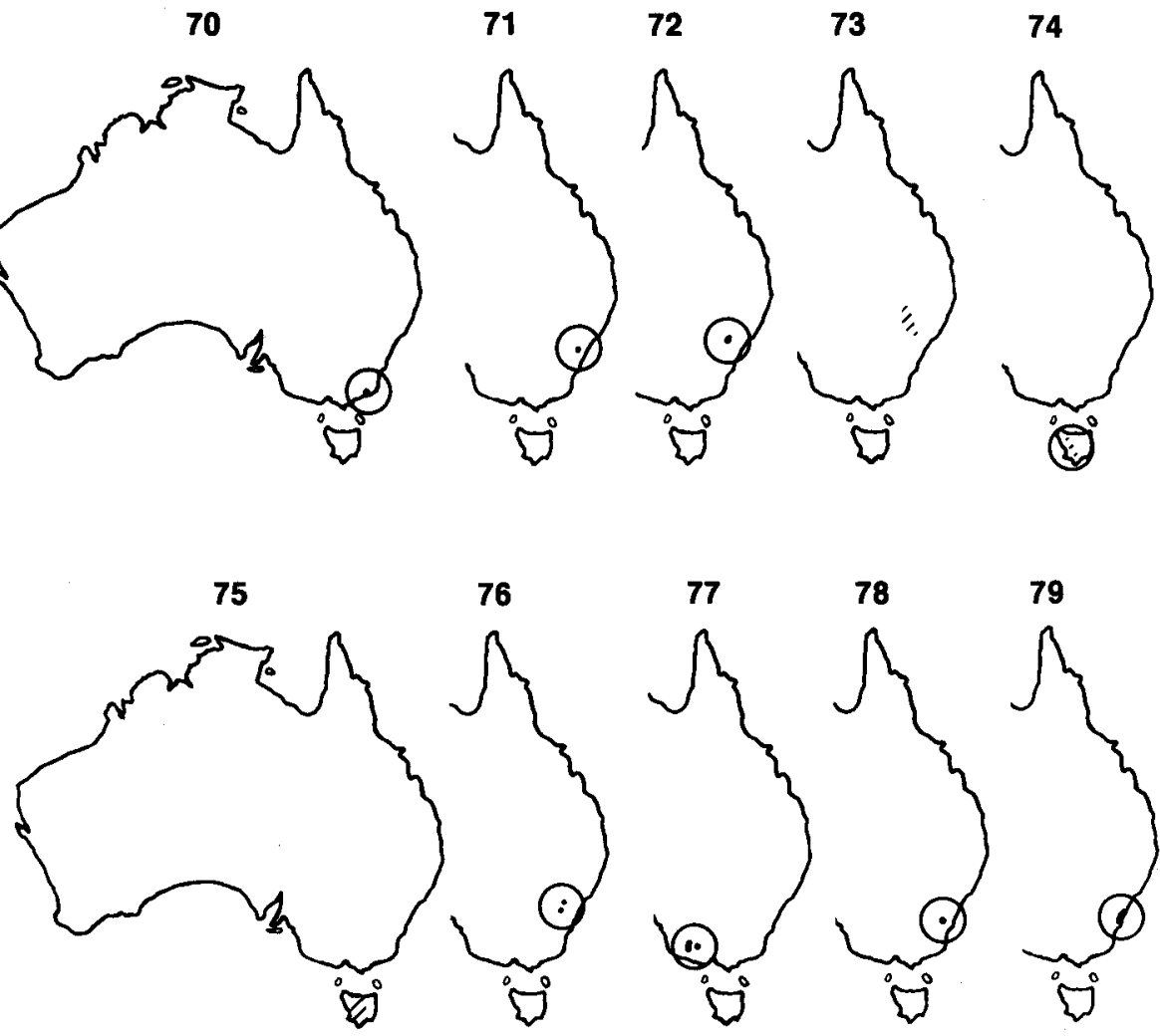

Map 9. Distribution of Group 2: subgroup 4 L. lanigerum and allies. 65. $L$. euense. 66. $L$. grandifolium. 67. L. lanigerum. 68. L. arachnoides. 69. L. thompsonii. 70. L. glabrescens. 71. L. spectabile. 72. L. macrocarpum. 73. L. sphacrocarpum. 74. L. riparium. 75 . L. nitidum. 76. L. petraeum. 77. L. turbinatum. 78. L. crassifolium. 79. L. epacridoideum. 
SE. of Mt Cobberas No 1, Walsh 869, 2.1982 (MEL, NSW). Western Highlands: on Lerderberg R., 2 miles [3.2 km] below Blackwood, Whaite NSW 154788, 12.1953 (NSW).

This species is variable, different leaf-forms being found in different parts of its range and in different habitats. The Type specimen represents the large-leaved riparian form found on sandstone creek banks in the northern Sydney district.

67. L. lanigerum (Sol. ex Aiton) Smith, Trans. Linn. Soc. London 3: 263 (1797).

Basionym: Philadelphus laniger Sol. ex Aiton, Hortus Kew., ed. 1, 2: 156 (1789).

TYPE: A plant cultivated from seed collected at Adventure Bay, Tasmania by Furneaux, in March 1773 (BM, n.v.). See Aiton, op. cit. 157 and Nelson, Telopea 2 (4): 347 (1983).

Synonymy: $P$. laniger var. canescens Sol. ex Aiton, loc. cit. TyPE: A plant from the above source.

$P$. laniger var. piliger Sol. ex Aiton, loc. cit.

L. pubescens Willd., Sp. Pl. 2: 950 (1799-1800) non Lam. (at least as to Type). L. lanigerum var. pubescens DC., Prodr. 3: 227 (1828), nom. illegit. L. lanigerum var. pubescens (Willd.) Hook. f., Fl. Tasman.: 139 (1856). TYPE: plant from the above source.

L. australe Salisb., Prodr. 350 (1796). TYPE: as for P. laniger.

L. microphyllum F. Muell. ex Miq., Ned. Kruidk. Arch. 4: 142 (1859), non Hoffmansegg. TYPE: SOUTH AUSTRALIA: Rivoly-bay [Rivoli Bay], F. Mueller, s.d. (U, n.v.).

L. microphyllum var. viride F. Muell. ex Miq., loc. cit. TYPE: SOUTH Australia: Rivolybay, F. Mueller (U, n.v.).

L. microphyllum var. glaucum F. Muell. ex Miq., loc. cit. TyPE: South Australia: Rivoly-bay, F. Mueller (U, n.v.).

L. pubescens forma angustifolia Miq., Ned. Kruidk. Arch. 4: 143 (1859). SYNTYPES: Barossa [South Australia]; ad ripas Yarra [Victoria] (U, n.v.).

L. pubescens forma minor Miq., loc. cit. TYPE: TASMANIA: Van Diemansland, Stuart (U, n.v.).

L. lanigerum var. montanum Rodway, Tasman. Fl. 52 (1903). TYPE: TASMANIA: not designated ("common in many parts [of Tasmania] in humid forests and subalpine localities").

Shrub or tree to $5 \mathrm{~m}$ or more in height, with close, usually firm, bark, at least on young plants; the younger stems rather stout and densely pubescent with short, and especially when very young, long, spreading hairs, without a flange but often widened below the leaf-base, and branching mostly at c. $45^{\circ}$. Leaves mostly divergent to spreading, from a few $\mathrm{mm}$ to $15 \mathrm{~mm}$ long, and mostly 2-4 mm wide, oblong to narrowly oblanceolate, usually grey-pubescent at least on the lower surface but sometimes glabrous on the upper surface, and rarely glabrous on both, the upper surface sometimes rather thick but rarely glossy, the margins usually but not invariably recurved, often strongly, the apex tapering rather abruptly and infolded behind a short pungent or blunt point, the base tapering to a distinct though often very short, often broad-based, petiole. Flowers white, c. $15 \mathrm{~mm}$ in diameter, occurring singly on modified shoots at the ends of short densely leafy side-branches, the subtending leaves often longerpetiolate or otherwise modified, the new growth very dense, extending from beyond the flowers after flowering. Bracts broad, stiff and pale- or red-brown, the inner somewhat larger than the broad bracteoles that allow the pubescence of the bud to protrude, many often tending to remain about the flower. Hypanthium densely villous, 3-5 $\mathrm{mm}$ long, the upper part expanded, the lower shallowly rounded or broadly tapered, often with a minute narrow pedicel, the top of the ovary glabrous. Sepals persistent, $2-4 \mathrm{~mm}$ long, deltoid to longdeltoid, densely villous or long-silky-pubescent, pale and with the tip often 
folded or hooded. Petals c. $6 \mathrm{~mm}$ long. Stamens in bundles of c. 7, c. 2-3 mm long, the anther-cells c. $0.5 \mathrm{~mm}$ long, parallel, much-thickened and wide open, deeper in the outer part, recurved but scarcely folded back. Style well inset, broad-based but slender, with a small stigma; often absent. Ovary (4-) 5-locular, each loculus with c. 50 ovules in 4-6 rows on a high, usually somewhat inset, placenta rather or very extended at the top; sometimes absent. Fruit persistent, $5-10 \mathrm{~mm}$ in diameter, the rim not or scarcely extended, the lower part broadly rounded but often flat-based, the surface lifting and becoming scaly, the valves very woody, raised only so as to form a low, rather lobed, dome depressed in the centre, after opening the surface lifting and the valves often a little more raised, usually ultimately becoming broader than the base. Mature seeds c. $2.5 \mathrm{~mm}$ long, narrowly linear-cuneiform, curved, striate. Main flowering period: Oct.-Jan.

Distribution: Widespread in Tasmania, and, on mainland Australia, from southeastern South Australia to southern and eastern Victoria and extending as scattered populations to the Central Tablelands of New South Wales (Map 9). In sandy swamps and along watercourses.

Selected SPECIMENS: New South Wales: South Coast: Towamba, Thompson 4250, 3.1982 (NSW). Central Tablelands: 1 mile $[1.6 \mathrm{~km}] \mathrm{N}$. of Taralga, Constable NSW $55267,1.1961$ (NSW). Southern Tablelands: Tidbinbilla Fauna [Nature] Reserve, A.C.T., Gray 5532, 9.1964 (CANB), Thompson 4167, 11.1984 (NSW). VICTORIA: East Gippsland: Reedy Creek, Wakefield 4219, 10.1948 (MEL, NSW), Haegi 1684, 2.1979 (NSW), Thompson 4232, 3.1982 (NSW). Western Highlands: Victoria Valley, beside Glenelg R. at Serra road crossing, Grampians, Corrick 8455, 8456, 11.1982 (MEL, NSW). SOUTH AUSTRALIA: Upper Southeast: $2 \mathrm{~km} \mathrm{NE}$. of Tooperang P.O., Haegi 551, 10.1974 (AD, NSW). TASMANIA: Road from George Town, Gunn 809/1842, 12.1841 (NSW); Frenchman's Cap track (at Franklin R.), Canning 2093, 1.1969 (CBG, NSW); Birch's Inlet, Macquarie Harbour, Milligan 713, 11.1846 (HO); W. edge of Platypus Tarn, Mt Field National Park, Short 1826, 1.1983 (MEL, NSW); S. Esk R., near Evandale, Buchanan 3578, 5.1984 (HO).

Many specimens from western Victoria lack the characteristic grey leafpubescence. It has not been possible to separate these as a distinct taxon; they appear to indicate the influence of genes of another species (see p. 338). A green-leaved form has been treated as a distinct variety by Miquel (1859).

68. L. arachnoides Gaertner, Fruct. Sem. P1. 1: 175, t. 35 (1788).

TYPE: The illustration in the above publication, based on a specimen in the Banksian herbarium (BM).

SyNONYMY: L. arachnoideum Smith, Trans. Linn. London Soc. 3: 263 (1797), nom. illegit. TYPE: as above.

L. baccatum Smith, op. cit. 264. TyPE: New SOUTH WALES: Port Jackson (according to Smith in Rees Cycl., sent to Kew Gardens by Sir Joseph Banks in 1790) (?LINN, n.v.). L. juniperifolium Cav., Icon. 4: 18, t. 331 (1797). TYPE: NEW SOUTH WALES: "a portu" Botany Bay (MA, n.v.).

L. triloculare Vent., Jard. Malm.: 88, t. 84 (1804-1805). TYPE: a garden plant "originaire de la Nouvelle Hollande".

Much-branched shrub, often almost prostrate but frequently erect and occasionally reaching more than $2 \mathrm{~m}$ in height, the bark rough and peeling in flaky layers; the younger stems stout, with long, spreading hairs over a persistent pubescence of usually very short, irregular, crisped hairs, without a flange but enlarged at each node, and with branching at c. $60^{\circ}-90^{\circ}$. Leaves at first narrowly divergent, not spreading from the base but the whole often recurved so as 
to appear so, usually $10-20 \mathrm{~mm}$ long and very variable (often regionally) in width from less than 1 to more than $3 \mathrm{~mm}$, elliptical to lanceolate or oblanceolate, glabrous or variously partially pubescent, thick, especially near the apex, the margins often minutely tuberculate, incurved, often strongly, and frequently infolded near the apex, the whole with a tendency to twist (spirally), the apex tapering and pungent-pointed, the base tapering, usually expanding again to a very short, broad somewhat triquetrous petiole. Flowers white, c. $10 \mathrm{~mm}$ in diameter, single on modified shoots at the ends of crowded, short, leafy, axillary branches, occasionally with the leaves subtending the shoots modified, the new growth dense, from many short branch-ends away from the flowering region before flowering, and with some development coming later from flowering shoots. Bracts almost spherical, stiff, and pale yellow- or redbrown, the outer often broad-based and pungent, the inner and bracteoles large and concave, allowing the pointed sepal-tips to extend beyond, and tending to remain about the open flower. Hypanthium usually pubescent with dense spreading hairs, occasionally the pubescence appressed or sparse, c. $2 \mathrm{~mm}$ long, the upper part somewhat expanded, usually tapering rather evenly to above a very short pedicel, the top of the ovary glabrous. Sepals persistent, c. $2 \mathrm{~mm}$ long, deltoid and somewhat hooded, appressed-pubescent but often also with many spreading hairs. Petals c. $4 \mathrm{~mm}$ long. Stamens in bundles of (3-)5-7, c. 2 $\mathrm{mm}$ long, the anther-cells $0.4-0.6 \mathrm{~mm}$ long, parallel, thickened but opening wide with a broader deeper outer part, variable but usually not much recurved or folded. Style not inset, very stout-based and stout with a medium-sized stigma. Ovary (3-) 4-5-locular, each loculus with c. 30-40 ovules in c. 6 rows on a close-set almost inset, shallow placenta. Fruit often long-persistent, from less than 5 to more than $8 \mathrm{~mm}$ in diameter, the rim somewhat extended and woody, the lower part almost hemispherical with the pubescent surface lifting and ultimately the surface flaky, the valves, before opening, only slightly exserted as a low dome depressed in the centre with the surface lifting and often tearing from the style-base, after opening usually not much further raised or much spreading. Mature seeds c. 1.5-2 mm long, linear-cuneiform, striate. Main flowering period: Nov.-Jan.

Distribution: From Stanthorpe, southeastern Queensland, to the Tinderry Range of southeastern New South Wales (Map 9). Usually in moist heath or forest, in shallow soils especially on sandstones and granite.

SELECTED SPECIMENS: QueENSLAND: Darling Downs: Stanthorpe, Boorman NSW 154781, 11.1904 (NSW). New SouTH WALES: North Coast: Nabiac aerodrome, Burgess 117, 3.1962 (NSW). Central Coast: Port Jackson, White, herb. Smith 878.18, 1795 (photo NSW); Maddens Plains, 2 km NE. of Sublime Point, Coveny 11119 \& Taylor, 6.1982 (NSW). South Coast: Pigeon House Range, Burgess B162, 11.1972 (CBG, NSW). Northern Tablelands: Torrington, Cambage 1637, 7.1907 (NSW). Central Tablelands: Mt Victoria-Bell road, Constable NSW 11118, 3.1950 (NSW). Southern Tablelands: Tinderry Range, c.30 miles [48 km] S. of Queanbeyan, Pullen 4424, 12.1971 (CANB, NSW). North Western Slopes: Ponds Creek, Tingha, Cambage 932, 10.1903 (NSW). Central Western Slopes: Lees Pinch, Wollar-Merriwa road, Johnson NSW 17636, 9.1951 (NSW).

\section{L. thompsonii $J$. Thompson sp. nov.}

Frutex usque ad $3 \mathrm{~m}$ vel altior. Folia late elliptica ad ovata, $1-1.5 \mathrm{~cm}$ longa. Flores c. $15 \mathrm{~mm}$ diametro, sepalis pubescentibus persistentibus. Ovarium 5-loculare. Fructus 9-12 mm diametro persistentes. 
Holotype: New South Wales: Clyde Mt, near Braidwood, J.L. Boorman NSW 154782, 12.1915 (NSW).

Tall usually erect shrub 1 to more than $2 \mathrm{~m}$ tall with rather fibrous and flaky rough bark; the younger stems stout, with a long fine spreading pubescence over a dense short irregular pubescence, with at least the latter persisting, without a flange but somewhat thicker below each node, and with branching at c. $30^{\circ}$ Leaves rather dense and mostly divergent, usually $10-15 \mathrm{~mm}$ long and 4-6 $\mathrm{mm}$ wide, broad-elliptical to obovate, thick, especially near the apex, and tending to incurve there, but otherwise flat or with the margins tending to recurve, both surfaces tardily glabrescent but hairs often persisting on the margins, the apex broadly acuminate with a broad pungent tip, the base narrowing to a short petiole often thickened behind at the base and frequently laterally enlarged there. Flowers white, c. $15 \mathrm{~mm}$ in diameter, single on modified shoots terminating leafless or leafy branches, occasionally with the leaves subtending the shoots modified, the new growth extending densely both from branch-ends and from flowering shoots after flowering. Bracts almost spherical, stiff and yellowto red-brown, the outer often broad-based and acuminate, the inner longest and concave, the bracteoles a little smaller, allowing the rather obtuse sepal-tips to protrude; all tending to remain about the opened flower. Hypanthium with a dense, long, fine pubescence, c. $4 \mathrm{~mm}$ long, the upper part somewhat spreading, the lower rather rounded above, or broadly tapering to, a negligible pedicel, the top of the ovary glabrous. Sepals persistent, c. $3 \mathrm{~mm}$ long, broadly ovate or almost hemispherical, with a rounded, rather hooded apex and with very dense long spreading hairs. Petals c. 4-6 mm long. Stamens in bundles of c. 7-9, c. 2-3 mm long, the anther-cells $0.5-0.7 \mathrm{~mm}$ long, parallel, thickened, with the outer part wide and deep, and somewhat recurved and folded back. Style inset, very broad-based, tapering to behind a medium-sized stigma. Ovary (4-) 5-celled, each loculus with c. 50 ovules in c. 6 rows on a large, broad, close, somewhat inset placenta. Fruit persistent, $9-10 \mathrm{~mm}$ in diameter, scarcely extended at the rim, the base rather shallowly rounded, the pubescent surface lifting, later flaky, the valves before opening only slightly exserted as a shallow dome with a depressed centre, later spreading and ultimately equal to or somewhat wider than the rim and often equalling the depth of the base. Mature seeds c. $2.5 \mathrm{~mm}$ long, irregularly linear-cuneiform, often curved, striate. Main flowering: probably Dec. (-Mar.).

DisTRIBUTION: Known only from the Clyde Mountain district of southeastern New South Wales (Map 9). In wet places, in forest.

SELECTED SPECIMENS: NeW SOUTH WaLES: Southern Tablelands: near Monga, Thompson 4170 \& Thompson, 11.1982 (NSW); Monga, Baeuerlen NSW 154783, 12.1898 (NSW).

This species is named for M.M.H. Thompson, my husband, whose assistance in the collection and field study of this and many other species has helped to enlarge understanding of this genus.

\section{L. glabrescens Wakef., Victorian Naturalist 72: 43 (1955) quoad Typum.}

TYPE: VICTORIA: Reedy Creek, Tamboon Road, Cann River valley, 20.1.1955, N.A. Wakefield, No. 4806, (MEL, NSW).

Tall shrub 1.5-4 m or more in height with firm bark; the younger stems rather stout, with a dense pubescence of very short crisped hairs and scattered long fine hairs, the former persisting but sometimes becoming sparse, without a flange but becoming thicker below each node, and with branching at $30^{\circ}-45^{\circ}$. Leaves rather narrowly divergent, at least at first, and dense, 5 to more than 
$10 \mathrm{~mm}$ long and mostly $1-3 \mathrm{~mm}$ wide, elliptical to linear, rather thick and in general flat, but often tending to incurve towards the apex or recurve at the margins, ultimately glabrous but with hairs tending to persist on the margins, the apex acute to acuminate and pungent-pointed, the base tapering to, or slightly rounded above, a broad-based, very short petiole, often thickened behind. Flowers white, c. $12 \mathrm{~mm}$ in diameter, single on modified shoots, on short few-leaved branches, with the subtending leaves tending to be modified, the new growth from branch-ends and, often quite vigorously, from flowering shoots after flowering. Bracts broad, often stiff, and yellow- to red-brown, the outer often broad-based and pungent, the inner and bracteoles very broad, very broadly obtuse and concave with the bracteoles tending to be somewhat smaller, enclosing only the young bud with the broad calyx-top soon exposed, but tending to be retained about the open flower. Hypanthium densely longvillous with rather crimped hairs, c. $3 \mathrm{~mm}$ long, the upper part not much expanded, the lower shallowly rounded, the top of the ovary glabrous. Sepals persistent, c. $2 \mathrm{~mm}$ long, densely villous, very short and broad, almost hemispherical, very broadly obtuse and rather hooded. Petals c. 3-5 mm long. Stamens in bundles of c. 7 , c. $2.5-3 \mathrm{~mm}$ long, the anther-cells c. $0.5-0.6 \mathrm{~mm}$ long, parallel, thickened, with the outer part deep, and tending to recurve and fold back. Style well inset, very broad-based, and tapering to a rather small stigma. Ovary 5-locular, each loculus with c. 30 ovules in 6 rows on an extended and narrow-topped, rather flat-surfaced placenta. Fruit persistent, some times quite long-persistent but not enlarging, c. 5-7 $\mathrm{mm}$ in diameter, widest at the scarcely extended rim, the lower part shallow and broadly rounded (the narrow base scarcely at all visible), sometimes somewhat lobed when young, the surface lifting, ultimately scaly, the valves woody, at first exserted as a rather low lobed dome with a central depression and later with the surface tending to lift, and spreading but usually not exceeding the rim so the fruit is relatively shallow and rather flat-topped. Mature seeds c. $2 \mathrm{~mm}$ long linear-cuneiform, somewhat sigmoid or curved, striate. Main flowering period: Dec.-Jan.

DisTRIBUTION: In the East Gippsland district of Victoria (Map 9). In sandy swampy heath or on creek banks.

Selected SPECIMENS: Victoria: East Gippsland: Reedy Creek, E. of Cann River, Wakefield, 2874, 12.1948 (NSW), 4220, 11.1948 (NSW), Haegi 1686, 2.1979 (NSW), Thompson 4231, 3.1982 (NSW); Dinner Creek, Tamboon road, Melville 2876 et al., 1.1953 (NSW); $4 \mathrm{~km}$ from Cape Conran on Conran-Cabbage Tree road, Thompson $4225,3.1982$ (NSW); $2 \mathrm{~km}$ from Cape Conran on Conran-Cabbage Tree road, Thompson 4224, 3.1982 (NSW).

Specimens from other areas included by Wakefield in his concept of L. glabrescens are not conspecific. These are (at least for the most part) forms of L. lanigerum.

\section{L. spectabile $J$. Thompson sp. nov.}

Frutex usque ad $3 \mathrm{~m}$ altus. Folia anguste elliptica, $2-3.5 \mathrm{~cm}$ longa. Flores c. 20 $\mathrm{mm}$ diametro sanguinei, sepalis sericeis persistentibus. Ovarium 4-5-loculare. Fructus 9-12 mm diametro persistentes.

Holotype: New SouTH WALEs: Colo River gorge below Boorai ridge, $12.7 \mathrm{mls}(20.4 \mathrm{~km})$ E. along Culoul Range road off Windsor-Singleton road [NW. of Windsor], $R$. Coveny $9125 \&$ P. Hind, 12.ii.1977 (NSW).

Shrub to $3 \mathrm{~m}$ tall with close firm and ultimately corrugated bark; the younger stems with long, fine, antrorse hairs and shorter curved hairs and with short 
crisped and irregular hairs persisting, scarcely or imperceptibly flanged but thickened below each node, and with branching usually at c. $30^{\circ}$ or even less. Leaves erect or very narrowly divergent at least at first, most from $20-35 \mathrm{~mm}$ long and mostly 3-5 mm wide, narrowly elliptical, rather firm in texture, with the surface often dull, usually almost flat, occasionally incurved in crosssection, ultimately almost glabrous but with hairs tending to persist at the base, tapering to a long-acute or -acuminate, slightly infolded and shortly, stiffly, pointed apex, the base tapering to a short petiole sometimes thickened at the back. Flowers a rather dark red, c. $20 \mathrm{~mm}$ in diameter, single on modified shoots on several-leaved leafy side-branches, the new growth extending from beyond the flowers after flowering. Bracts broad, concave and light- to redbrown, the innermost and bracteoles more scarious; the bracteoles not shorter but folded over the pointed sepals; all shed before the flower opens. Hypanthium densely covered with long, rather loosely appressed, silky hairs, c. 4-5 mm long, the upper part spreading widely, the lower broadly tapering to an extremely short to negligible pedicel, the top of the ovary glabrous. Sepals persistent, c. $4 \mathrm{~mm}$ long, ovate-oblong, obtuse and rather hooded, broad-based and rather pale, with a long, appressed, silky pubescence. Petals c. 5-7 mm long. Stamens in bundles of c. 9,5-7 mm long, the filaments occasionally with scattered spreading hairs, the anther-cells $1.0-1.2 \mathrm{~mm}$ long, parallel, very much thickened and opening wide, with the outer part rather deep, not much recurved but to some extent folded back. Style not inset, stout-based and rather stout, with the stigma small (in relation to the style); frequently undeveloped. Ovary 4-5-locular, each loculus with c. 80 ovules in 8 rows on a large, close, high placenta; sometimes absent. Fruit persistent but not enlarging, c. $9-12 \mathrm{~mm}$ in diameter, widest at the distinct but not woody rim, below the lower part hemispherical, with or without an almost negligible stalk, the valves very woody, before opening much exserted to form a tall often rather narrowly rounded dome minutely dished in the centre but raised to the high style-base, on opening tearing from the style and spreading to the width of the rim or somewhat beyond, the fruit usually appearing to be deeper than wide. Mature seeds c. $6 \mathrm{~mm}$ long, linear-cuneiform, long-sigmoid, striate. Main flowering period: Nov.

Distribution: Found only along the Colo River in central eastern New South Wales (Map 9). Among sandstone boulders on the river bank.

Selected SPECIMENS: New South WaLES: Central Coast: Colo Gorge, c. $1 \mathrm{~km}$ upstream from Boorai Creek junction, Haegi 1604 \& Hind, 1.1979 (NSW); c. 2 miles [3.2 km] up the Colo R., Sanders NSW 153050, 11.1976 (NSW); lower Colo R. c. 4 miles [6.4 km] above Lower Portland, Cooper NSW 153049, 11.1957 (NSW).

This species has been named for its large red flowers. It is closely related to L. sphaerocarpum.

\section{L. macrocarpum (Maiden \& Betche) $J$. Thompson comb. nov.}

BASIONYM: Leptospermum lanigerum (Sol. ex Aiton) Smith var. macrocarpum Maiden \& Betche, Proc. Linn. Soc. New South Wales 23: 12 (1898).

LeCtOTYPE, here chosen: New South WALES: Mt. Tomah, J. Gregson NSW 154788, 11.1897 (NSW). There is, in NSW, only one Gregson specimen from Mt Tomah, but two specimens from Mt Wilson (dated 11.1897 and 12.1897) appear to have been used in drawing up the protologue.

Shrub, low-growing or to $2 \mathrm{~m}$ in height, spreading and diffuse or, less frequently, erect and compact, the bark close, densely layered and becoming 
gnarled; the younger stems stout with a dense short crisped pubescence and a scarcely perceptible flange, but much thickened below the nodes, and often branching at $60^{\circ}$ or more. Leaves erect, spreading or even deflexed, from less than 10 to $20 \mathrm{~mm}$ or more long and mostly $5-10 \mathrm{~mm}$ wide, usually broadly elliptical but often wider near the apex, firm, with the surface rather dull and usually flat, ultimately glabrous but with hairs tending to remain longer on the margins and persist at the base, the apex obtuse or acute, often infolded near a short stiff point, the base usually tapering but occasionally almost cordate above a distinct petiole. Flowers greenish white, pink or dark red, $15-30 \mathrm{~mm}$ in diameter, single on modified shoots on short leafy side-branches, the new growth after reddish, vigorous from branch-ends beyond the flowering region during flowering and less so from the flowering shoots after flowering. Bracts very broad, large, stiff, red-brown and concave, the inner, and somewhat smaller bracteoles, very broadly obtuse, about the broad-topped bud but shed before the flower opens. Hypanthium usually densely covered with long silky hairs, the hairs occasionally shorter and more sparse on the upper part, 4-8 $\mathrm{mm}$ long, the upper part widely expanded, the lower tapering to a broad base, the top of the ovary glabrous. Sepals persistent, c. 7-8 mm long, almost orbicular, to broadly ovate, broadly obtuse, broad-based and densely covered with a long silky pubescence. Petals c. 4-8 mm long. Stamens in bundles of 9-11, 6-9 $\mathrm{mm}$ long, the filaments somewhat joined at the base, the anther-cells c. 1.0-1.2 $\mathrm{mm}$ long, parallel, recurved and somewhat folded back, very much thickened with the outer part deep, but opening wide. Style not inset, broad-based and stout, with a rather small stigma; frequently absent. Ovary (4-) 5-locular, each loculus with c. 100-200 ovules in 8-12 or more rows on a large, rather shallow, almost inset, high placenta; sometimes absent. Fruit long-persistent but not enlarging, often 15-20 mm in diameter, widest at the broad, rather woody rim, the lower part broadly rounded with the base sometimes almost flat, the valves very woody, well exserted, at first forming a wide dome sometimes rather flat-topped or almost dished but raised in the centre to the style-base, on opening tearing from the style base and spreading but usually not wider than the rim, the fruit usually appearing much wider then deep. Mature seeds c. 5 $\mathrm{mm}$ long, narrowly linear-cuneiform, curved, striate. Main flowering period: Oct.-Dec.

Distribution: Restricted to a small area in the Blue Mountains, New South Wales (Map 9). Usually on rocky exposed or rather dry sites on sandstone.

Selected SPecimens: New South Wales: Central Coast: above Colo R. gorge on Boorai ridge, Coveny 9117 \& Hind, 2.1977 (NSW); Woodford, Bowden NSW 154786, 10.1950 (NSW). Central Tablelands: Mt Victoria on the Victoria Falls road, Coveny 4146, 4.1972 (NSW).

73. L. sphaerocarpum Cheel, J. \& Proc. Roy. Soc. New South Wales 65: 204 (1932).

LeCTOTYPe, here chosen: New South WALES: at foot of range about 8 miles [13 $\mathrm{km}$ ] from Rylstone, $E$. Cheel NSW 143045, 9.10.1931 (NSW).

Shrub to $2 \mathrm{~m}$ in height, usually erect, rarely spreading, the bark close and firm; the younger stems rather stout, usually with a dense short pubescence and often with a few to numerous, long, ascending hairs, the longer hairs rarely persisting, without a flange but thickened below each node, and branching at c. $45^{\circ}$. Leaves at first almost erect, later divergent, mostly 5-20 $\mathrm{mm}$ long and 2-5 $\mathrm{mm}$ wide, broadly to narrowly elliptical, rather thick, with the surface often dull, flat or somewhat re- or incurved in cross-section, ultimately almost glabrous but with hairs tending to persist at the base, the apex tapering to an acute or 
long-acute, slightly infolded, pungent point, the base broadly or narrowly tapered to a short, broad and broader-based petiole with a thickening behind. Flowers a rather greenish white or pink, (10-) 15-20 $\mathrm{mm}$ in diameter, single on modified shoots at the ends of leafy side-branches, the new growth extending from beyond the flowers, after flowering. Bracts broad, stiff, concave and paleor red-brown, the inner and bracteoles more scarious, the bracteoles not, or scarcely, smaller but allowing the broadly acute bud-tip to protrude, all shed well before the flower opens. Hypanthium with a dense silky pubescence or glabrous apart from a few hairs at the base and top, dark, with rather obvious glands, 3.5-5 $\mathrm{mm}$ long, the upper part expanded widely and all tapering to a base rounded above a minute pedicel, the top of the ovary glabrous. Sepals rather persistent, $3.5-5 \mathrm{~mm}$ long, usually broadly ovate, obtuse and hooded, with a broad base, scarious and relatively pale, and silky-pubescent or glabrous apart from the apex and margins. Petals c. 5-7 $\mathrm{mm}$ long. Stamens in bundles of c. 9, 4-6 $\mathrm{mm}$ long, the anther-cells c. 0.7-1.0 $\mathrm{mm}$ long, parallel, thickened and deep especially in the outer part, and opening wide, recurved but not folded back. Style not or scarcely inset, stout-based and rather stout, with the stigma small in relation to the style; often undeveloped. Ovary 3-5-locular, each loculus with c. 40 ovules in c. 6 rows on a broad, short, close, sometimes extended, rather high placenta; sometimes absent. Fruit persistent but not enlarging, usually 7-10 $\mathrm{mm}$ in diameter, with a distinct but not woody rim, the lower part almost hemispherical, sometimes above a very short stalk, the valves very woody and much exserted, forming a tall rounded or rather flat-topped dome, after opening, breaking away from the style-base, and spreading, often as wide as the rim, the fruit usually appearing to be as deep or deeper than wide. Mature seeds 4-6 mm long, usually irregularly narrowly linear-cuneiform (bent at one end), striate. Main flowering period: Oct.-Nov.

Distribution: Extending from the Warrumbungle Ranges to the Central Tablelands of New South Wales, and on adjacent dry parts of the Central Coast region (Map 9). In light soils, especially on sandstone, in heath or sclerophyll forest on ridges or escarpments.

SELECTED SPECIMENS: NeW SouTh WALES: Central Coast: Yango track, near Wollombi, Story 6656, 9.1959 (NSW). Central Tablelands: Khyber Pass, c. 30 km E. of Kandos, Jackson 2197, 10.1972 (AD, NSW); Bell-Mt Wilson road, Garden NSW 153048, 8.1950 (NSW). North Western Slopes: Warrumbungle Ranges, Forsyth NSW 153047, 10.1899 (NSW), NSW 143046, 10.1901 (NSW). Central Western Slopes: Currant Mountain Gap, $24 \mathrm{~km}$ E. of Rylstone, Coveny 9552, 9.1977 (NSW).

74. L. riparium D. Morris in D. Morris \& W.M. Curtis, Rec. Queen Victoria Mus. 50: 2 (1974).

Holotype: TASMANia: west side of bridge over Huon River, Tahune Forest Park, D.I. Morris, 7.i.1974 (HO). ISOTYPES: HO, K, NSW.

Tall straggling shrub $3 \mathrm{~m}$ or more in height with flaking bark; the younger stems slender but relatively broad-based, with long fine hairs and a short close irregularly spreading pubescence, the latter tending to persist, with an inconspicuous but thick, flange, and branching at $45^{\circ}-60^{\circ}$. Leaves divergent to spreading or even deflexed, (5-) 10-25 mm long and mostly 2-4 mm wide, most narrowly oblanceolate and somewhat falcate, mostly glabrous but with pubescence often persisting on margins and at the base, firm and almost flat but slightly infolded near the tip and sometimes with the margins tending to recurve, the apex 
acuminately or acutely tapering to a rather recurved point, the base tapering to a broad, relatively thin and often somewhat twisted petiole. Flowers probably always white, $15-20 \mathrm{~mm}$ in diameter, single on modified shoots at the ends of leafy branches with the petioles of subtending leaves often elongated, the new growth reddish and extending from flowering shoots after flowering. Bracts pale- or reddish-brown, stiff and broad, the inner and bracteoles long but allowing the very narrow tip of the bud to protrude, all shed before the flower opens. Hypanthium with a dense short pubescence, c. $4 \mathrm{~mm}$ long, the upper part very widely expanded, the lower rather shallowly rounded above a narrow, tapering, conspicuously fluted pedicel of variable length (c. 0-2 $\mathrm{mm}$ ), the top of the ovary glabrous. Sepals persistent, 4-6 $\mathrm{mm}$ long, long-deltoid, with a long silky pubescence, at least for the most part, the margins pale and scarious, and inrolled in the upper part with the tip infolded. Petals $8-9 \mathrm{~mm}$ long. Stamens in bundles of c. 7 , c. $4 \mathrm{~mm}$ long, the anther-cells $0.5-0.7 \mathrm{~mm}$ long, parallel, recurved and folded back, the outer part deep but all much thickened and opening wide. Style inset, very slender, but rather broad-based, with a small stigma. Ovary 5-locular, each loculus with c. 80 ovules in c. 6 rows on a large, close, almost inset placenta. Fruit persistent, $6-8 \mathrm{~mm}$ in diameter, the rim not extended, the lower part rather turbinate, usually above a short stalk, the surface lifting and becoming scaly, the valves very woody, raised to form a broad, shallow dome, on opening not spreading wider than the rim. Mature seeds not seen. Main flowering period: Jan.

DisTRIBUTION: In the mountains of western Tasmania (Map 9). On the banks of swift-flowing rivers in rainforest.

Selected specimens: Tasmania: Pieman R. Bridge, Davies \& Davies NSW 134555, 1.1937 (NSW); Franklin R., Gunn 1962, NSW 134554, 2.1845 (NSW); Gordon R., Davies \& Davies, Rodway 2465, 1.1937 (NSW), L. Rodway 2694, 12.1892 (NSW).

\section{L. nitidum Hook. f., Fl. Tasman. 1: 139 (1856).}

SynTYPES: TASMANIA: Rocky Cape, Gunn [813/1842, 29.12.1837], (K, n.v.; dupl. NSW); heathy plains between Macquarie Harbour and Lake St Clair, Gunn (K, n.v.). There are specimens in NSW, 'heathy hills, Cape Sorrel, Macquarie Harbour, J. M/illigan] 366, herb. Gunn 813/1842, 3.5.1842' and 'heathy and peaty plains, Macquarie Harbour, Gunn 813, Nov. 1846', and in HO, 'Rocky Cape, Gunn 813/1842, 4.10.1838' and 'Detention Corner, Macquarie Harbour, Gunn 813, 10.2.1845'.

SyNONYMY: L. flavescens var. nitidum (Hook. f.) Rodway, Tasman. Fl.: 53 (1903). L. pubescens var. nitidum (Hook. f.) Domin, Biblioth. Bot. 89: 453 (1928).

Compact shrub often $2 \mathrm{~m}$ tall with scaly layered bark; the stems stout, with a dense, long, fine, antrorse pubescence soon giving way to short close hairs, without a flange but with a narrow ridge subtending each leaf-base, and branching densely at c. $60^{\circ}$ but curving so as to appear to be at a narrower angle. Leaves aromatic, dense, erect or narrowly divergent, usually $8-20 \mathrm{~mm}$ long and 3-6 mm wide, elliptical, mostly glabrous on both surfaces but often with pubescent margins, flat or with a slight tendency to recurve, usually glossy, the texture rather thick especially near the apex, the apex broad-acute to -acuminate, somewhat infolded or curved, with a short, usually pungent, point, the base tapering to or rounded above a short broad-based petiole. Flowers white, usually c. $15 \mathrm{~mm}$ in diameter, single on modified shoots at the ends of dense leafy side-branches whose upper leaves are often reduced in size, and with the new growth extending beyond the flowers after flowering. Bracts stiff, golden brown, concave, the inner longest with the bracteoles fractionally shorter, all enclosing only the young bud but some tending to be caught among 
the flowers. Hypanthium densely long-pubescent or occasionally with fewer or short hairs or almost glabrous, 4-6 $\mathrm{mm}$ long, the upper part expanded, the lower tapering to or rounded above a short rather fluted pedicel, the top of the ovary glabrous. Sepals persistent, often 5-6 mm long, very long-deltoid, silkypubescent with pale margins and an inrolled and rather folded minutely hooded tip. Petals c. $6 \mathrm{~mm}$ long. Stamens in bundles of c. 7, 2.5-3 mm long, the anther-cells $0.5-0.8 \mathrm{~mm}$ long, parallel, much-thickened but wide open with the outer part deeper, and somewhat recurved and folded. Style deeply inset, and rather slender with a small style. Ovary 5-locular, each loculus with c. 60 ovules in c. 6 rows on a large, rather narrow-topped, rather inset, placenta. Fruit long-persistent, usually $6-10 \mathrm{~mm}$ in diameter, the rim woody but very narrow, the lower part usually rather straight-sided, the base broadly rounded or flat, the surface lifting and flaking, later scaly, the very woody valves scarcely exserted, and usually on opening little further raised and scarcely extended. Mature seeds c. $2.5 \mathrm{~mm}$ long, narrowly linear-cuneiform, curved, striate. Main flowering period: Jan.

Distribution: Widespread in Tasmania, including Cape Barren Island (Map 9). In cold moist heathy places, often on granite.

Selected specimens: Tasmania: c. 3 miles [5 km] from Savage River, towards Waratah, Canning 1966, 1.1969 (CBG, NSW); Strahan, Davis \& Davis, Rodway 2484, 1.1937 (HO, NSW), Rodway 1530, 10.1933 (NSW), Garden NSW 19392, 19393, 1.1949 (NSW); junction of Scotts Peak road and Condominium Creek, South West National Park, Short 1802, 1.1983 (MEL, NSW); Lake Margaret, Garden NSW 19394, 1.1949 (HO, NSW).

\section{L. petraeum $J$. Thompson sp. nov.}

Frutex usque ad $3 \mathrm{~m}$ altus. Folia late elliptica, c. $1.5 \mathrm{~cm}$ longa, apicibus pungentibus. Flores sepalis longideltoideis sericeis persistentibus. Ovarium 5-loculare. Fructus 7-8 mm diametro persistentes.

Holotype: New South Wales: Rocky Top, Kanangra, J. Thompson 4303, 23.8.1982 (NSW).

Spreading rigid shrub to $3 \mathrm{~m}$ tall, with bark close on small branches but later flaking in strips, the younger stems very stout, with a short pubescence and a flange seen only as a thickening extending below the leaf-base, and with branching at $45^{\circ}-60^{\circ}$ or more but later curving so as to appear at a narrower angle. Leaves rather aromatic, mostly narrowly divergent, variable in size but usually c. $15 \mathrm{~mm}$ long and 5-6 $\mathrm{mm}$ wide, rather broadly elliptical, glabrescent with both surfaces soon glabrous and glossy but hairs persisting on margins and the petiole, the texture rather thick, the surface often tending to incurve or infold especially near the apex but older leaves flat or even slightly recurved in cross-section, the upper part tapering to an acute or acuminate, pungentpointed apex, the base rounded above a distinct somewhat thick-based petiole. Flowers white, c. $22 \mathrm{~mm}$ in diameter, single on modified shoots at the ends of short leafy side-branches, the subtending leaves often somewhat modified, the new growth developing from the flowering shoot after flowering. Bracts and bracteoles similar, broad, stiffly scarious and yellowish-brown. Hypanthium glabrous or with a short dense pubescence, $4 \mathrm{~mm}$ long, the upper part much expanded, the lower rounded above a stout, short, fluted pedicel, the top of the ovary glabrous. Sepals persistent, c. 4-6 mm long, long-deltoid, glabrous or with a close silky pubescence on the lower part, and, usually, long hairs on the upper, inrolled or folded with the tip minutely hooded. Petals c. $7 \mathrm{~mm}$ long. Stamens in bundles of 7 , c. $2.5-3 \mathrm{~mm}$ long, the anther-cells c. $0.7 \mathrm{~mm}$ long, 
somewhat recurved and folded, wide open and thickened, the outer part deep. Style inset, slender and tapered, with a small stigma. Ovary 5-locular, each loculus with c. 40 ovules in c. 6 rows on a large, close-set placenta. Fruit long-persistent, c. 7-8 $\mathrm{mm}$ in diameter, the rim not much extended, the lower part rather broadly rounded with the surface lifting, later flat-based and scaly, the valves very woody, exserted at first only as a low dome but on opening the surface lifting and the valves rising and spreading so as to be about equal to the base in depth and somewhat broader than the rim. Mature seeds c. $2 \mathrm{~mm}$ long, linear-cuneiform, striate. Main flowering period: Uncertain; one specimen Nov., one April, one in young fruit Oct.

DISTRIBUTION: known only from a population on an exposed granite outcrop and an old herbarium specimen without field notes, both from the Central Tablelands of New South Wales (Map 9). In rock crevices.

SPECIMENS EXAMINED: New South WALES: Central Tablelands: Rocky Top, Kanangra, Johnson NSW 154790, 10.1948 (NSW), Garden NSW 154789, 4.1956 (NSW); Blackheath, Close NSW 154805, 11.1923 (NSW).

This species is named for its habitat.

\section{L. turbinatum $J$. Thompson sp. nov.}

Frutex 1-2 m altus. Folia obovata oblanceolata vel elliptica pungentia, $1-2 \mathrm{~cm}$ vel longiora. Flores c. $25 \mathrm{~mm}$ diametro, sepalis sericeis, longideltoideis persistentibus. Ovarium (4-)5(-6)-loculare. Fructus 7-11 mm diametro turbinati persistentes.

HolOTYPE: VICTORIA: on steep slopes and sandstone rocks of Mackay's Peak, Serra Range, near Hall's Gap, Grampians, $R$. Melville 1847, P. Morris, C. D'Alton \& R. Warry, 30.x.1952 (NSW).

Spreading shrub usually $1-2 \mathrm{~m}$ in height with (as seen on specimens) close, firm bark; the younger stems rather stout with a short close pubescence, without a flange but with a narrow ridge subtending each leaf-base, the branching rather variable but usually at $45^{\circ}-60^{\circ}$. Leaves aromatic, mostly rather narrowly divergent, 10-20 or more $\mathrm{mm}$ long and usually $4-8 \mathrm{~mm}$ wide; somewhat smaller near the flowers, elliptical to obovate or oblanceolate, ultimately glabrous and glossy but the fine spreading pubescence of young leaves rather persistent, thick in texture and flat or minutely infolded near the tip, the apex acuminate and pungent with a rather stout point, the base tapering gradually or more suddenly to a distinct tapering petiole. Flowers white, c. $25 \mathrm{~mm}$ in diameter, single on modified shoots terminating adjacent leafy side-branches, the new growth extending from beyond the flowers after flowering. Bracts very broad, pale yellowish-brown and stiff, the inner and bracteoles longest (the latter somewhat shorter than the final bract) tightly rolled around the young bud, but allowing the pointed bud to protrude, and sometimes held about the opening flower. Hypanthium with a long dense silky pubescence, c. $5 \mathrm{~mm}$ long the upper part widely expanded, the lower somewhat tapering and fluted but rounded at the base with a minimal pedicel, the top of the ovary glabrous. Sepals persistent, 5-7 mm long, long-deltoid, with a long, dense, silky pubescence, the tip infolded and minutely hooded. Petals c. $12 \mathrm{~mm}$ long. Stamens in bundles of $7-9$, c. $5 \mathrm{~mm}$ long, the anther-cells c. $0.8 \mathrm{~mm}$ long, parallel, much-thickened but wide open and with the outer part deep, recurved and somewhat folded back. Style rather shallowly inset, moderately stout and tapering, with the stigma small in relation to the style. Ovary (4-) $5(-6)$-locular, each loculus with c. 80 ovules in c. 8 rows on a rather small, high, inset, placenta with the top 
somewhat extended. Fruit persistent, c. 7-11 $\mathrm{mm}$ in diameter, the rim rather broad and woody, the lower part usually rounded and eventually tapering to a narrow base,the surface lifting, later firm and gnarled, the valves very woody, exserted to a rather variable extent, forming a broad- or narrow-topped dome, on opening with the surface lifting, the valves usually failing to extend to any extent. Mature seeds, c. $4 \mathrm{~mm}$ long, irregularly narrowly linear-cuneiform, sigmoid, striate. Main flowering period: Nov.

Distribution: Limited to the Grampians and adjacent ranges in western Victoria (Map 9). In sandy soil on rocky sandstone slopes.

Selected SPECIMENS: Victoria: Western Highlands: Mt William, Phillips 586, 11.1971 (CBG, NSW); W. slope of Boronia Peak, Muir 822, 9.1959 (MEL, NSW).

This species is named for the shape of its fruit, by which it can be distinguished from $L$. nitidum with which it has been confused.

\section{L. crassifolium $J$. Thompson sp. nov.}

Frutex 1-2 m altus. Folia crassa nitida, usque ad $7 \mathrm{~mm}$ longa. Flores c. $18 \mathrm{~mm}$ diametro, sepalis longideltoideis sericeis pubescentibus. Ovarium (4-)5loculare. Fructus $8-10 \mathrm{~mm}$ diametro longipersistentes.

Holotype: New South Wales: N. side of Mt Corang, northern Budawang Range, c. 40 km NE. of Braidwood, $R$. Pullen $4972 \& J$. Story, 26 Sept. 1973 (NSW). IsOTYPE: CANB.

Shrub 1-2 $\mathrm{m}$ in height with (as seen on specimens) close bark; the younger stems rather stout with a minute close pubescence, without a flange but thickened around the leaf-bases, branching at c. $60^{\circ}$ but often soon curving. Leaves somewhat aromatic, dense, and rather erect at first, later diverging and usually with the upper part recurving, mostly $7 \mathrm{~mm}$ or less in length and 3-4 mm wide, broadly elliptical, very thick in texture, incurved in cross-section and often infolded near the apex, glabrous and very glossy with prominent glands on the lower surface, the margins often minutely pubescent, the apex broadly acute, usually with a stout blunt point, the base broad above a distinct often broadbased petiole. Flowers white, c. $18 \mathrm{~mm}$ in diameter, single on modified shoots terminating leafy side-branches, the new growth extending from branch-ends and from beyond the flowers after flowering. Bracts large, very broad and concave, almost spherical, golden brown and rather thin, stiff but translucent, the inner and bracteoles longer but enabling the long-pointed sepals to protrude, many tending to persist about the open flower. Hypanthium glabrous apart from a minute pubescence on the upper parts and rather dark, c. $5 \mathrm{~mm}$ long, the upper part not much expanded; the lower rather straight-sided and rounded above a fluted pedicel, the top of the ovary glabrous. Sepals persistent, c. $5 \mathrm{~mm}$ long, long-deltoid, with a thin silky pubescence, the margins pale, the upper part infolded and the tip hooded. Petals c. $7 \mathrm{~mm}$ long. Stamens in bundles of 5-7, c. $4 \mathrm{~mm}$ long, the anther-cells $0.6-0.7 \mathrm{~mm}$ long, somewhat recurved and folded, much-thickened and opening wide but deep in the outer part. Style inset, evenly slender or with a very short broad base, the stigma rather small. Ovary (4-) 5-locular, each loculus with c. 80 ovules in (6-) 8-rows on a large, rather shallow and close-set placenta. Fruit long-persistent with the base becoming very broad, mostly $8-10 \mathrm{~mm}$ in diameter, the rim woody but not much expanded, the lower part rather straight-sided or rounded above a broad base, the surface lifting as a very thin layer, the valves very woody, exserted to form only a very low dome with a small central depression, after opening the surface lifting, and the valves raised and spreading to some extent 
so as to be less wide than the rim and usually about half the depth of the base. Mature seeds c. $2.5 \mathrm{~mm}$ long, linear-cuneiform, striate. Main flowering period: Feb. and perhaps later.

DisTRIBUtion: On peaks of the Budawang Range in southeastern New South Wales (Map 9). In moist peaty sand and rock crevices, on sandstone

SELECTED SPECIMENS: NEW SOUTH WALES: Southern Tablelands: S. end of Quilties Mountain, D. Black NSW 154791, 11.1981 (NSW); Corang Trigonometrical Station, Olsen 953, 2.1969 (NSW). This species is named for its leaf-texture.

79. L. epacridoideum Cheel, J. \& Proc. Roy. Soc. New South Wales 53: 121 (1919) (as L. epacridioideum, an error resulting from the wrong use of a connecting vowel).

LeCtOTYPE, here chosen: New South WaLES: Jervis Bay, Dr. F.A. Rodway NSW 154792, 2.1916 (NSW).

Erect rather rigid bushy shrub, usually more than $2 \mathrm{~m}$ in height, with close firm bark, corrugated towards the base of the plant; the younger stems very stout, with a very minute, often rather retrorse pubescence that persists onto older growth, with no flange and scarcely raised below the nodes, often branching at $60^{\circ}$ but frequently soon becoming more erect. Leaves somewhat aromatic, dense and erect or narrowly divergent with the lamina tending to recurve, 2-3 mm long and c. $2 \mathrm{~mm}$ wide, broadly elliptical to almost orbicular, incurved in cross-section and very thick in texture, especially in the upper part, glabrous and very glossy, with prominent glands on the lower surface the apex rounded, often with a thickened umbo behind, the base broad above a distinct short, broad and very thick-based petiole. Flowers white or pink, c. $10 \mathrm{~mm}$ in diameter, single on modified shoots on short or long leafy side-branches, the new growth from branch ends and beyond flowers after flowering. Bracts large, very broad, almost spherical and concave, stiff but not very thick, golden- to redbrown, the longer inner ones and even slightly longer bracteoles enclosing the narrow young bud but soon allowing the long sepal-tips to protrude, tending to persist about the flower. Hypanthium glabrous, and dark with obvious glands, or occasionally with a minute pubescence at the top, c. $3 \mathrm{~mm}$ long, the upper part a little expanded, the lower almost hemispherical, the top of the ovary glabrous. Sepals persistent, c. $3.5 \mathrm{~mm}$ long, long-deltoid, minutely pubescent especially near the apex and on the pale margins, the margins infolded and the apex minutely hooded. Petals c. $5 \mathrm{~mm}$ long. Stamens in bundles of c. $5(-7)$, c. $2.5 \mathrm{~mm}$ long, the anther-cells c. $0.5 \mathrm{~mm}$ long, parallel, very much thickened and wide open but deep in the outer part, recurved and folded back. Style inset, rather slender, with a stigma of medium size. Ovary 5- (-6) locular, each loculus with c. 60 ovules in 6 rows on a large, close-set placenta. Fruit longpersistent and becoming broad-based, up to $8 \mathrm{~mm}$ in diameter, the rim woody but scarcely extended, the lower part usually almost hemispherical, the surface lifting in a thin layer and becoming gnarled, the valves very woody, exserted only as a low dome before opening, and the opening reluctant or restricted, occasionally the valves lifting and spreading to some extent. Mature seeds c. $2 \mathrm{~mm}$ long, linear-cuneiform, striate. Main flowering period: Feb.-Mar.

Distribution: Almost confined to the Jervis Bay area of southeastern New South Wales (Map 9). In poor sandy, often moist heath and dry sclerophyll forest, on sandstone. Recent study of the area has failed to confirm the Central Coast record. 
Selected specimens: New South Wales: Central Coast: Austinmer, G. Rodway NSW 154793, 7.1933 (NSW). South Coast: Flat Rock Creek, on Yalwal road, Coveny 10975 \& James, 9.1981 (NSW); Sassafras-Tomerong road, c. $1.6 \mathrm{~km}$ from Nowra turn-off, Blaxell 1241 \& Benson, 2.1974 (NSW); Jervis Bay, Gauba 5608, 2.1953 (CBG, NSW).

\section{Unidentified taxa}

L. pubescens Lam., Encycl. 3: 466 (1791). Described from living material said to have come from New Zealand but, from the description, probably L. lanigerum (publ. 1789) from Tasmania.

L. recurvifolium Salisb., Prodr.: 350 (1796). Based on a 1791-1792 collection by D. Burton from Port Jackson. From the description probably L. arachnoides (publ. 1788) but perhaps L. squarrosum (publ. 1788).

L. multiflorum Cav., Icon. 4.: 17, t. 331 (1797). A mixed concept ("prope Paramata et Jackson"), with elements of L. polygalifolium (publ. 1796) and L. juniperinum (publ. 1797).

L. stellatum Cav., op. cit. 4: 16, t. 330. A mixed concept with elements of L. polygalifolium (publ. 1796) and L. trinervium (publ. 1790).

L. pungens Dum.-Cours., op. cit.: 385. A name of uncertain application described from living material grown from seed sent under this name "par $M$. Banks".

L. villosum Fischer, Cat. Jard. Gorenki, ed. 2: 63 (1812). Publication not seen but species based on material of a garden plant grown in Moscow.

L. tuberculatum Poir. in Lam., Encycl., Suppl. 3: 338 (1813). Based on a specimen collected by Labillardière (herb. Desf., FI, n.v.). Usually assumed to be L. lanigerum (publ. 1789). The FI specimen has not been found (Guymer, pers. comm.).

L. rubricaule Cels ex Link, Enum. Hort. Berol. Alt. 2: 25 (1822). Described from a garden plant of Australian origin. From the description perhaps L. squarrosum (publ. 1788).

L. cuneatum Hoffsgg., Verz. Pfl.-Kult.: 72, 175 (1824). Described from material from a Dresden or Rammerau garden plant; probably a form of L. lanigerum (publ. 1789).

L. microphyllum Hoffsgg., loc. cit. Described from material from a Dresden or Rammerau garden plant.

L. thymifolium Hoffsgg., op. cit.: 72, 176. Described from material of a Dresden or Rammerau garden plant.

L. obliquum Colla, Hortus Ripul., App. 2: 351 (1826). Described from a cultivated plant without flowers.

L. scoparium var. rubricaule (Cels ex Link) DC., op. cit.: 227. See L. rubricaule Cels ex Link (1822).

L. tuberculatum var. subenerve DC., op. cit.: 227. A brief description based on a dried specimen without provenance that has not been found in De Candolle's herbarium (G-DC, NSW microfiche).

L. buxifolium Dehnh., Cat. Horti Camald. 1: 172 (1829). Publication not found but species, if valid, described from cultivated material. The name is certainly published in ed. 2, 1: 172 (1839), and there an origin in Tasmania is suggested. 
S. Schauer, in 1841, considered this to be L. grandiflorum (publ. 1821).

L. tortuosum Dehnh., op. cit. 1: 171. See above but of different origin.

L. buxifolium Otto \& A. Dietr., Allg. Gartenzeitung 1: 186 (1833) non Dehnh. (1829). There are probably no extant specimens of species described in this series of papers. They were based on living material and any specimens would have been in $\mathrm{B}$.

L. acutifolium Otto \& A. Dietr., op. cit. 9: 225 (1841).

L. ciliolatum Otto \& A. Dietr., op. cit. 9: 241 (1841).

L. villosum Otto \& A. Dietr., op. cit. 9: 242 (1841), non Fischer (1812).

L. acerosum Schauer ex Otto \& A. Dietr., op. cit. 9: 250 (1841).

L. cupressinum Otto \& A. Dietr., op cit. 9: 250 (1841).

L. cuneiforme Otto \& A. Dietr., op. cit. 9: 251 (1841).

L. pungens Otto \& A. Dietr., op. cit. 9: 260 (1841), non Dum.-Cours. (1811).

L. candollei S. Schauer, Linnaea 15: 440, 441 (1841). Based on material (without number) collected by A. Cunningham, in 1825, in inland New South Wales. Schauer confused Leptospermum taxa, and cited Cunningham's specimens (often without number) by manuscript herbarium names in synonymy of many species.

L. grandifolium var angustum S. Schauer, op. cit.: 413. Based on a Murrey specimen (without number) from Moreton Bay, n.v.; probably, from the locality, a form of $L$. trinervium.

L. grandifolium var. argyreum S. Schauer, op. cit.: 413. Based on an A. Cunningham specimen (without number) from Tasmania, collected in 1819, n.v. but likely to be a form of $L$. lanigerum.

L. grandifolium var. vestitum S. Schauer, op. cit.: 413. Based on an A. Cunningham specimen collected in New South Wales in 1822, n.v., and not identifiable without number.

L. lanigerum var. concolor S. Schauer, op. cit.: 415. From "Nova Hollandia orientale". This would be either $L$. lanigerum sens. str., $L$. trinervium or (most likely) $L$. grandifolium. Schauer confused these species.

L. lanigerum var. discolor S. Schauer, op. cit.: 415. From "Nova Hollandia orientale". This is likely to be a form of $L$. grandifolium.

L. oxycedrus S. Schauer (as L. Schauer), op. cit.: 432. From "Hollandia orientale", but the description was based on a cultivated plant, perhaps but not certainly L. squarrosum (publ. 1788).

L. scoparium var. confertifolium S. Schauer, op. cit.: 425 . From the specimens cited, a mixed and unidentifiable concept.

L. tonsum S. Schauer, op. cit.: 422. From "Nova Hollandia"; a plant seen cultivated with reference also to a specimen in Willdenow's herbarium, n. 9458, "without flowers".

L. pilosum Schauer in Walp., Rep., Suppl. 1: 923,(1843). Based on a specimen from Tasmania, A. Cunningham 84, that Bentham failed to find in Cunningham's herbarium. J. D. Hooker in 1856 , in describing L. nitidum, suggested that this may be conspecific, but the description of the calyx suggests otherwise. Current searching has not located this specimen. 
L. bullatum Loud., Hort. Brit., Suppl. 3: 576 (1850) nom. nud.

L. pubescens var. commune Domin, Biblioth. Bot. 89: 453 (1928). Domin was referring here to, and cites in synonymy, L. pubescens Lam. (1791) sens. str.

L. pubescens var. tonsum (S. Schauer) Domin, op. cit.: 453. See S. Schauer (1841).

\section{Excluded taxa}

L. ciliatum Forst. \& Forst. f., Char. Gen:: $72(1776)=$ Purpureostemon ciliatus.

L. collinum Forst. \& Forst. f., loc. cit. = Metrosideros collina.

L. leucadendron (L.) Forst. \& Forst. f., loc. cit. = Melaleuca leucadendra.

L. perforatum Forst. \& Forst. f., loc. cit. = Metrosideros perforata.

L. scandens Forst \& Forst. f., loc. cit. = Metrosideros scandens.

L. virgatum Forst. \& Forst. f., loc. cit. = Baeckea virgata.

L. umbellatum Gaertner, Fruct. Sem. Pl.: 174, t. 30 (1788) = Eucalyptus umbellata.

L. salicifolium Lam., Encycl. 3: $467(1791)=$ a plant with opposite leaves, from Java.

L. ambiguum Smith, Trans. Linn. Soc. London 3: 264 (1797) = Kunzea ambigua.

L. imbricatum Smith, Trans. Linn. Soc. London 6: 300 (1802) = Baeckea imbricata.

L. marginatum Labill., Nov. Holl. Pl. 2: 10, t. $148(1806)=$ Agonis marginata.

L. brevifolium Rudge, Trans. Linn. Soc. London 8: $169(1807)=$ Baeckea brevifolia.

L. resiniferum Bertol., Amoen. Ital.: $29(1819)=$ Agonis flexuosa .

L. glomeratum Wendl. f., Flora 2: $678(1819)=$ Agonis flexuosa.

L. flexuosum Link, Enum. Hort. Berol. Alt. 2: 26 (1822) = Agonis flexuosa.

L. celsianum Ten., Ind. Sem. Hort. Neap.: 11, n. 13 (1823), (according to Steudel, Nomencl. Bot., ed. 2: $31(1840))=$ Metrosideros sp.

L. parvulum Labill., Sert. Austro-caledon. (1823): 62, t. $61=$ Baeckea parvula.

L. pinifolium Labill., op. cit.: 63, t. $62=$ Baeckea pinifolia.

L. dubium Sprengel, Syst. Veg. 2: $492(1825)=$ ? Astartea $\mathrm{sp}$.

L. linearifolium DC., Prodr. 3: $227(1828)=$ Agonis linearifolia.

L. scabrum (Thunb.) Wallich, Cat. n. 3650 (1831) = Deutzia scabra.

L. stamineum (R.Br.) Wallich, op. cit. n. $3651=$ Deutzia staminea .

L. ericoides A. Rich., Voy. Astr. 1: 338 (1832) = Kunzea ericoides.

L. buxifolium Otto \& A. Dietr., Allg. Gartenzeitung 1: 186 (1833), non Dehnh. $(1829)=$ a plant with crenate leaves.

L. angustifolium Endl. in Endl. \& al., Enum. Pl.: 50 (1837) = Hypocalymma angustifolium. 
L. ellipticum Endl., op. cit. = Pericalymma ellipticum.

L. robustum Endl., op. cit.: $50=$ Hypocalymma robustum.

L. hypericifolium Otto \& A. Dietr., Allg. Gartenzeitung 9: 243 (1841) = Agonis sp. (?theiformis).

L. styphelioides S. Schauer., Linnaea 15: $423(1841)=$ Melaleuca styphelioides.

L. crassipes Lehm., Sem. Hort. Bot. Hamburg (1842) = Pericalymma ellipticum.

L. splendens Schauer, in Walp., Rep., Suppl. 1: 923 (1843) = a plant with axillary subracemose flowers.

L. laricifolium Cunn. ex. Schauer, op. cit.: $922=$ Astartea fascicularis.

L. longifolium? Cunn. in R. Heward, J. Bot. 4: 243 (1841). A scarcely valid description of a southern Australian plant, possibly Agonia flexuosa.

L. fabricia Benth., Fl. Austral. 3: 102 (1867) = Neofabricia myrtifolia.

L. firmum (Schauer) Benth., op. cit.: $104=$ Homalospermum firmum.

L. floridum (Schauer) Benth., op. cit.: $110=$ Pericalymma ellipticum.

L. sinclairii Kirk, Stud. Fl. New Zealand: $158(1899)=$ Kunzea ericoides.

L. javanicum var. papuana F. Muell., Descr. Notes Papuan Pl.: 59 (1890) = a plant with flowers in terminal clusters.

L. benningsenianum Volk. in Engl., Bot. Jahrb. Syst. 31: 470 (1902) = Myrtella benningseniana.

L. mjoebergii Cheel, J. \& Proc. Roy. Soc. New South Wales 53: 120 (1919) = Neofabricia mjoebergii.

L. phylicoides (as phylicoideum) Cheel, op. cit. 76: 231 (1943) = Kunzea ericoides.

\section{Acknowledgements}

I would like to thank the Directors of the following herbaria for kindly lending or allowing me access to their collections: AD, BRI, CANB, CBG, HO, L, MEL, NSW, PERTH.

Many of my colleagues at NSW and elsewhere have been most helpful, especially with regard to collection of material. Dr B. Jackes of the James Cook University, Townsville, has most generously supplied specimens and photographs of, and results of laboratory tests on, northern Queensland species. Dr B.J. Wallace (NSW) made observations, accompanied by photographs, of the two species on Mt Kinabalu, Borneo, while Mr L.J. Forlonge (Royal Botanic Gardens, Sydney) photographed the genus in a Type locality on Mt Apo, in the Philippines. Mr A. N. Rodd (NSW) photographed L. javanicum in the Type locality of this species on Mt Gedeh, Java. I am especially grateful to the Australian Botanical Liaison Officers, Dr G. Guymer (BRI), Dr J. West (CANB), Mrs K.L. Wilson (NSW) and Mr C. Dunlop (DNA) who have located Type specimens and copied literature unavailable in this country, and to $\mathrm{Mr} \mathrm{N}$. Byrnes (BRI) who forwarded copies of photographs of significant specimens at $\mathrm{K}$ and LINN. Mrs K. L. Wilson, Dr B. G. Briggs, Dr P.H. Weston and Dr P. G. Wilson have generously applied their expertise and time to problems of presentation of data. Discussions with Dr B.G. Briggs and Dr L. A. S. Johnson on the place of Leptospermum in the Myrtaceae have greatly helped interpretation of my observations, and the lucid expression of them. I would also like to thank an anonymous referee for a number of helpful suggestions. The line drawings were prepared by Mr K. D. Mackay and the maps by Mr Peter Richards. Ms E. H. Norris has 
prepared specimens for the electron microscope and taken the S.E.M. micrographs included here, and Mrs S. McCahon and Ms C. Douglas have patiently typed a large and often very confused manuscript. My husband, Mr M. M. H. Thompson, has not only provided often much-needed encouragement but has accompanied me on most of the extensive field work involved and photographed many of the species collected.

Funding from the Royal Botanic Gardens and Domain Trust and from the Australian Biological Resources Survey is most gratefully acknowledged.

\section{References}

Axelrod, D:I. (1972). Edaphic aridity as a factor in Angiosperm evolution. Amer. Naturalist 106: 311-320.

Axelrod, D.I. (1979). The role of plate tectonics in Angiosperm history. In Gray, J. \& Boucot, A.J. (eds), Historical biogeography, plate tectonics and the changing environment. (Oregon State University Press.)

Axelrod, D.I. \& Raven, P.H. (1982). Paleobiogeography and origin of the New Guinea flora. In Gressit, J.L. (ed.), Monographiae Biologicae 22. (W. Junk, The Hague.)

Baas, P. (1977). The peculiar wood structure of Leptospermum crassipes. Int. Assoc. Wood. Anat. Bull. No.2: 25-30.

Bamber, R.K. (1962). The anatomy of barks of the Leptospermoideae. Austral. J. Bot. 10: $25-54$.

Beadle, N.C.W. (1966). Soil phosphate and its role in molding segments of the Australian flora and vegetation, with special reference to xeromorphy and sclerophylly. Ecology 47: 992-1007.

Beadle, N.C.W. (1981). The vegetation of Australia. (Gustav Fischer Verlag, Stuttgart; New York.)

Beard, J.S. (1982). The structure and floristics of shrublands, woodlands and forests in South-Western Australia. Ecologia Mediterranea 8: 241 (1982).

Bentham, G. (1867). Fl. Austral. 3: 100-111. (Lovell Reeve \& Co., London.)

Brass, L.J. (1955). Report of the Archbold expedition to Cape York. Bull. Amer. Mus. Nat. Hist. 102: 186, t. 43 (2).

Briggs, B.G. \& Johnson, L.A.S. (1979). Evolution in the Myrtaceae - evidence from inflorescence structure. Proc. Linn. Soc. New South Wales 102: 157-256.

Burrell, J. (1965). Ecology of Leptospermum in Otago. New Zealand J. Bot. 3: 3-16.

Burrell, J. (1981). Invasion of coastal heaths of Victoria by Leptospermum laevigatum (J. Gaertn.) F. Muell. Austral. J. Bot. 29: 747-764.

Carlquist, S. (1971). Ecological factors in wood evolution. A floristic approach. Amer. $J$. Bot. 64: 887-898.

Carr, S.G.M., Carr, D.J. \& Ross, F.L. (1971). Male flowers in eucalypts. Austral. J. Bot. 19: $78-88$.

Chailakhyan, M.Kh., \& Khrianin, V.N. (1987). Sexuality in Plants and its Hormonal Regulation. (Springer - Verlag, New York).

Cheel, E. (1943). A revision of certain species of Leptospermeae. J. \& Proc. Roy. Soc. New South Wales 76: 229-234.

Cook, J.M., Mark, A.F., \& Shore, B.F. (1980). Responses of Leptospermum scoparium and Leptospermum ericoides (Myrtaceae) to waterlogging. New Zealand J. Bot. 18: 233-246.

Curtis, W.M. \& Morris, D.I. (1975). The students Flora of Tasmania, ed. 2, 1: 199-202 (Government Printer, Tasmania.)

Dawson, M.I. (1987). Contributions to a chromosome atlas of the New Zealand flora 29, Myrtaceae. New Zealand J. Bot. 25: 367-369.

Diels, L., (1922). Die Myrtaceen von Papuasien. Bot. Jahrb. Syst. 57: 356-426.

Domin, K. (1928). Beiträge zur Flora und Pflanzengeographic Australiens (Myrtaceae). Biblioth. Bot. 89: 451-454.

Fleming, C.A., (1975). The geological history of New Zealand and its biota. In Kuschel, G. (ed.), Biogeography and Ecology in New Zealand. (W. Junk, The Hague.) 
Flynn, T.M., Lassak, E.V. \& Smyth, M.P. (1979). The volatile leaf oils of three species of Leptospermum. Phytochemistry 18: 2030-2031.

Funk, V.A. (1985). Phylogenetic patterns and hybridization. Ann. Missouri Bot. Gard. 72: $681-715$.

Hellyer, R.O. \& Pinhey, J.T. (1966). The structure of grandiflorone, a new $\beta$-triketone. $J$. Chem. Soc. (c): 1496-1497.

Ingle, H.D. \& Dadswell, H.E. (1953). Anatomy of the timbers of the south-west Pacific area. Part IV. Myrtaceae. Austral. J. Bot. 1(3): 353-401.

James, S.H., \& Hopper, S.D. (1981). Speciation in the Australian flora. In Pate, J.S., \& McComb, A.J. (eds.), The biology of Australian plants, 361-381. (University of Western Australia, Nedland.)

Jarman, S.J., \& Brown, M.J. (1983). A definition of Cool Temperate Rainforest in Tasmania. Search 14: 81-87.

Johnson, C.T. (1980). The leaf anatomy of Leptospermum Forst. (Myrtaceae). Austral. J. Bot. 28: 77-104.

Johnson, C.T. (1983). A contribution to the floral anatomy of Leptospermum laevigatum. S. African J. Bot. 2: 202-208.

Johnson, C.T. (1984). The wood anatomy of Leptospermum Forst. (Myrtaceae). Austral. J. Bot. 32: 323-337.

Johnson, L.A.S. \& Briggs, B.G. (1984). Myrtales and Myrtaceae - a phylogenetic analysis. Ann. Missouri Bot. Gard. 71: 700-756.

Kemp, E.M. (1981). Tertiary palaeogeography and the evolution of the Australian climate. In Keast, A. (ed.). Ecological biogeography of Australia. (W. Junk, The Hague.)

Krauss, S. (1986). Variation in Leptospermum attenuatum Sm. (unpublished B.Sc. (Hons.) thesis: University of Sydney).

Lamont, B. (1979). Root Systems of the Myrtaceae. Australian Plants 10: 72-78.

Lange, R. (1978). Carpological evidence for fossil Eucalyptus and other Leptospermae... from a tertiary deposit in the South Australian arid zone. Austral. J. Bot. 26(2): 221-233.

Lee, D.W., \& Lowry, J.B. (1980). Plant speciation on tropical mountains: Leptospermum (Myrtaceae) on Mount Kinabalu, Borneo. J. Linn. Soc., Bot. 80: 223-242.

Löve, A., \& Löve, D. (1971). Polyploidie et geobotanique, Naturaliste Canad. 98: 469-494.

Margaris, N.S. (1981). Adaptive strategies in plants dominating Mediterranean-type ecosystems. In di Castri, F. Goodall, D.W., \& Specht, R.L. (eds.), Ecosystems of the world 11: Mediterranean-type shrublands. (Elsevier Scientific Publishing Co., Amsterdam-Oxford-New York.)

Martin, H.A. (1981). The Tertiary flora. In Keast, A., (ed.). Ecological biogeography of Australia. (W. Junk, The Hague.)

Miquel, F.A.W. (1859), Stripes Nova-Hollandas a Ferd. Müllero collectas; determinavit F.A.W. Miquel. Ned. Kruidk. Arch. 4: 97-150.

Mohan, E., Mitchell, N., \& Lovell, P. (1984). Environmental factors controlling germination of Leptospermum scoparium (Manuka). New Zealand J. Bot. 22: 95-101.

Monitor (1981). Environment forces plants to change sex. New Scientist 89: 339.

Morley, B.D., \& Toelken, H.R. (1983). Flowering plants in Australia. (Rigby, Adelaide).

Morrison, D.A., \& Myerscough, P.J. (1982). Genecological differentiation in Leptospermum flavescens $\mathrm{Sm}$. in the Sydney region. Austral. J. Bot. 30: 461-475.

Morrison, D.A. (1984). Altitudinal variation in Leptospermum flavescens Sm. (Myrtaceae) Austr. J. Ecology 9: 203-205.

Moussel, B. (1965). Contribution a l'étude cyto-taxonomique des Myrtaceae. Mèm. Mus. Natl. Hist. Nat. Ser. B, Bot. 16: 41-125.

Mueller, F. (1890). Descriptive notes on Papuan Plants 9: 59 (1890). (Melbourne Government Printer.)

Parsons, R., \& Specht, R.L. (1967). Lime chlorosis and other factors affecting the distribution of Eucalyptus on coastal sands in southern Australia. Austral. J. Bot. 15: $95-105$. 
Penfold, A.R. (1922). The essential oils of two Leptospermums. J. \& Proc. Roy. Soc. New South Wales 56: 162-169.

Penfold, A.R., Morrison, F.R. \& Smith-White, S. (1942). The occurrence of two physiological forms of Leptospermum citratum (Challinor, Cheel and Penfold) as determined by chemical analysis of the essential oils. J. \& Proc. Roy. Soc. New South Wales 76: 93-95.

Primack, R.B., \& Lloyd, D.G. (1980). Andromonoecy in the New Zealand montane shrub Manuka, Leptospermum scoparium (Myrtaceae). Amer. J. Bot. 67: 361-368.

Primack, R.B., \& Lloyd, D.G. (1980a). Sexual strategies in plants IV. New Zealand J. Bot. 18: 109-114.

Ronghua, Y., Mark, A.F., \& Wilson, J.B. (1984). Aspects of the ecology of the indigenous shrub Leptospermum scoparium (Myrtaceae) in New Zealand. New Zealand $J$. Bot. 22: 83 .

Rye, B.L. (1979). Chromosome number variation in the Myrtaceae and its taxonomic implications. Austral. J. Bot. 27: 547-573.

Schauer, S. (1841). Kritische Revision der in deutschen Gärten Vorkommenden Arten der Gattung Leptospermum. Linnaea 15: 409-442.

Scott, A.J., (1978). A new species of Myrtella (Myrtaceae) from Australia and a synopsis of the genus. Kew. Bull. 33(2): 299-302.

Smith, J.M.B. (1981). An introduction to the history of Australasian vegetation. In Smith, J.M.B. (ed.), A history of the Australasian vegetation. (McGraw-Hill, Sydney.)

Smith-White, S. (1948). Cytological studies in the Myrtaceae. Proc. Linn. Soc. New South Wales 73: 16-36.

Specht, R.L. (1981). Responses to fires in heathlands and related shrublands. In Gill, A.M., Groves, R.H., \& Noble, I.R. (eds.), Fire and the Australian biota. (Australian Academy of Science, Canberra.)

Stebbins, G.L. (1952). Aridity as a stimulus to evolution. Amer. Naturalist 86: 33-44.

Steenis, C.G.G.J. van, (1981). Rheophytes of the world. (Sijthoff \& Noordhof, Alphen aan den Rijn, The Netherlands, Rockville, Maryland, U.S.A.)

Thompson, J. (1983). Redefinitions and nomenclatural changes within the Leptospermum suballiance of Myrtaceae. Telopea 2: 379-383.

Thompson, J. (1986). A revision of the genus Leptospermum ... (unpublished M.Sc. thesis: University of Sydney).

Tison, E. (1876). Recherche sur les caractères de la placentation et de l'insertion dans les Myrtacées. (Librairie F. Savy. Paris.)

Wendland, J.C. \& Schrader, H.A. (1797). Sertum Hannoveranum seu plantae rariores quae Hortis Regiis Hannoveri vicinis coluntur. (Vandenhoeck et Ruprecht, Göttingen.)

White, C.T., \& Francis, W.D. (1920). Contributions to the Queensland Flora. Bot. Bull. Dept. Agric. 22: 16.

Willis, J.H. (1973). A handbook to plants in Victoria 2: 444-449. (Melbourne University Press.)

Wong, K.M. (1982). Mountain Gelam of Kinabalu. Nature Malaysiana 7: 4-7.

Wyk, A. Evan, Robbertse, P.J., \& Kok, P.D.F. (1983). The genus Eugenia (Myrtaceae) in southern Africa: Structure and taxonomic value of wood. S. Afr. Tydskr. Plantk. 2: $136-151$. 
Species

\section{Index}

L. arachnoides Gaertner . . . . . . . . . . . . . . . . . . . . . . . . 428

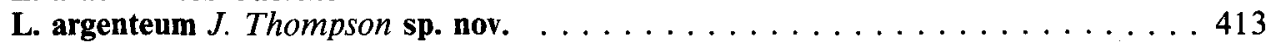

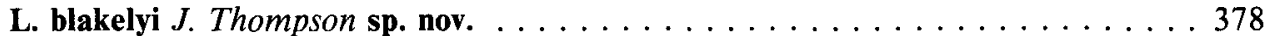

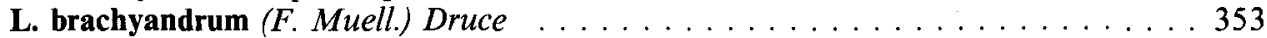

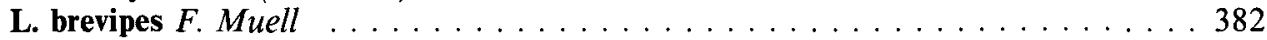

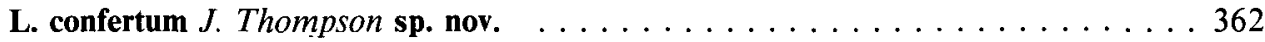

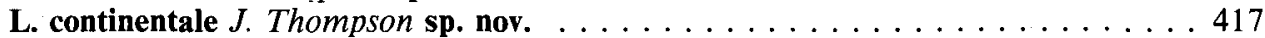

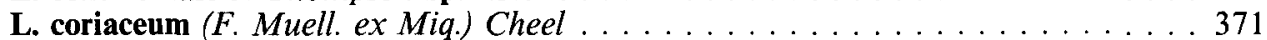

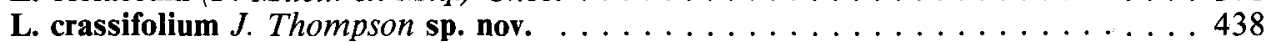

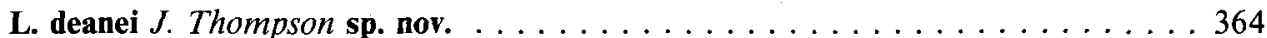

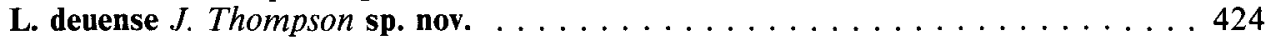

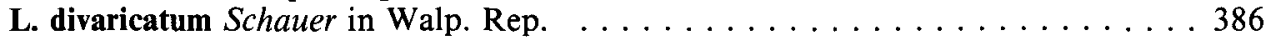

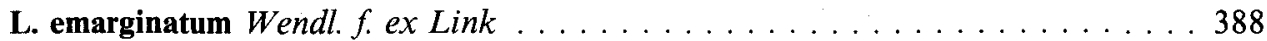

L. epacridoideum Cheel . . . . . . . . . . . . . . . . . . . . . . . . . 439

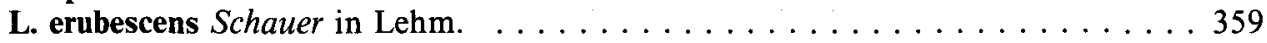

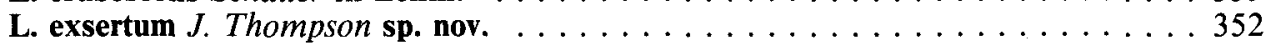

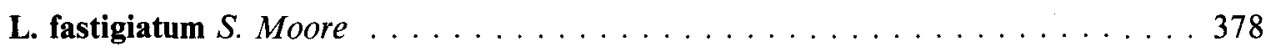

L. glabrescens Wakef. . . . . . . . . . . . . . . . . . 430

L. glaucescens $S$. Schauer . . . . . . . . . . . . . . . . . . . 370

L. grandiflorum Lodd. . . . . . . . . . . . . . . . . . . . . . . . . 4223

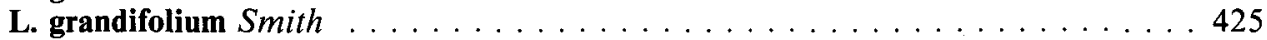

L. gregarium $J$. Thompson sp. nov. $\ldots \ldots \ldots \ldots \ldots \ldots \ldots \ldots \ldots \ldots$

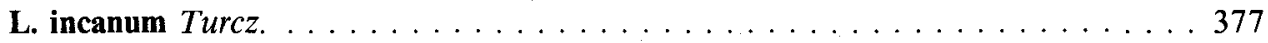

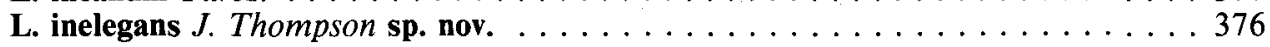

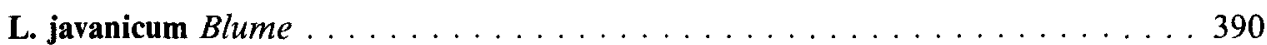

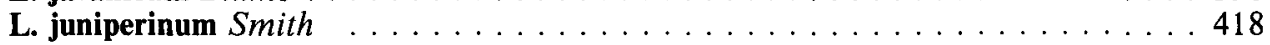

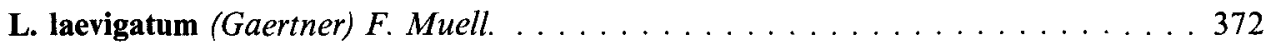

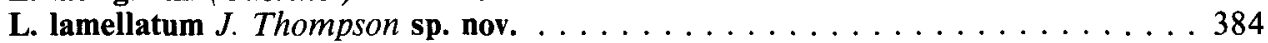

L. lanigerum (Sol. ex Aiton) Smith . . . . . . . . . . . . . . . . . . 427

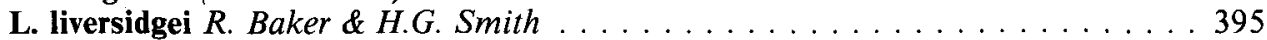

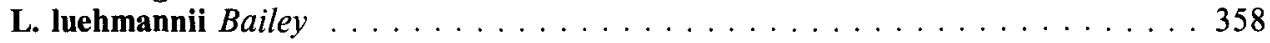

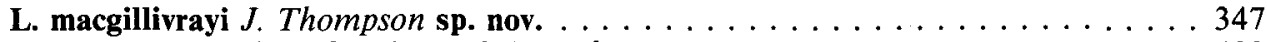

L. macrocarpum (Maiden \& Batche) J. Thompson comb. nov. . . . . . . . . 432

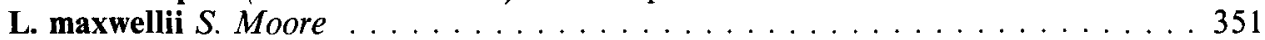

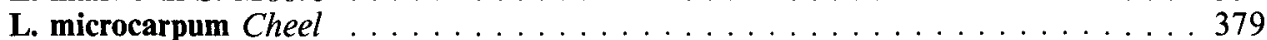

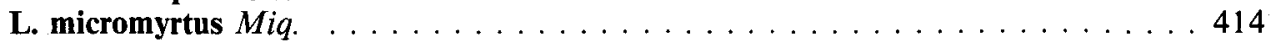

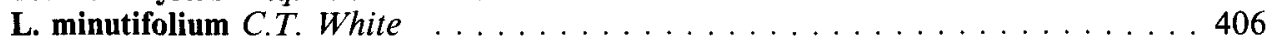

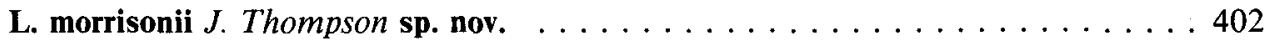

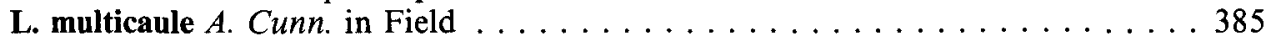

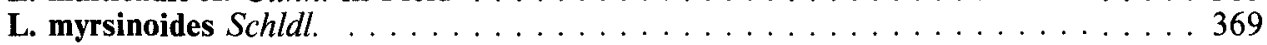

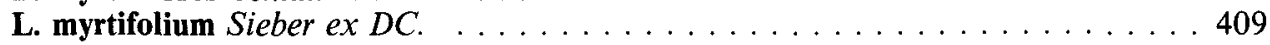

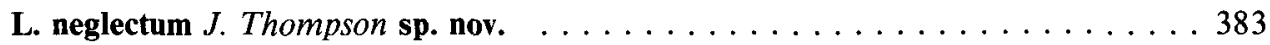

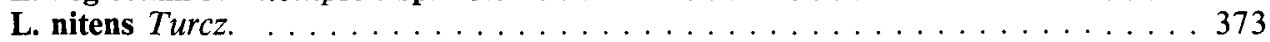

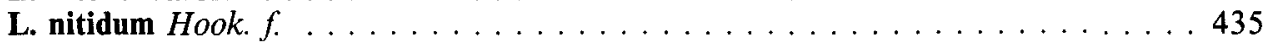

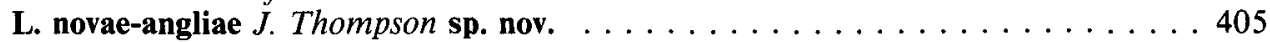

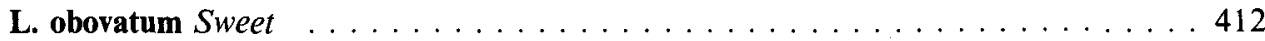

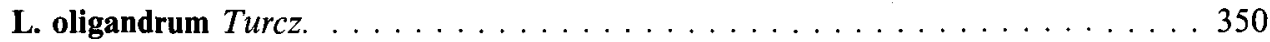

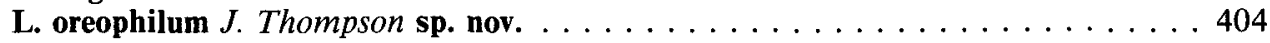


page

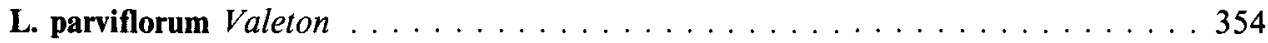

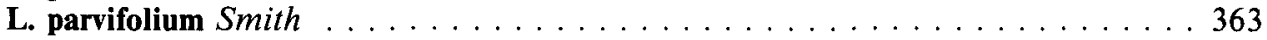

L. petersonii Bailey . . . . . . . . . . . . . . . . . . . . . . . . 393

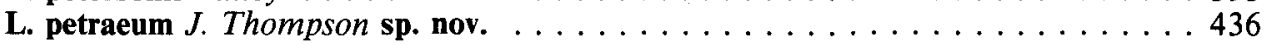

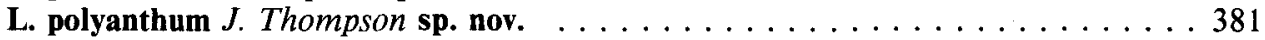

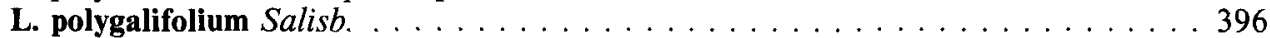

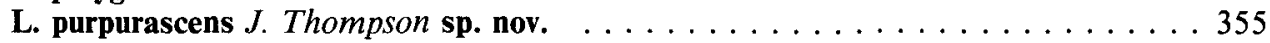

L. recurvum Hook. $f$. . . . . . . . . . . . . . . . . . . . . . . 391

L. riparium D. Morris in D. Morris \& W. M. Curtis . . . . . . . . . . . . . . . 434

L. roei Benth. . . . . . . . . . . . . . . . . . . . . . . . . . . . . . . . . 374

L. rotundifolium (Maiden \& Betche) F. Rodway ex Cheel . . . . . . . . . . . . . . 422

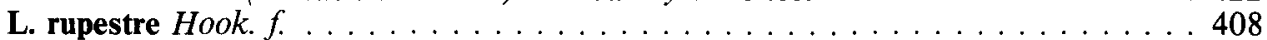

L. rupicola $J$. Thompson sp. nov. . . . . . . . . . . . . . . . . . . . . . 420

L. scoparium Forst. \& Forst. f. . . . . . . . . . . . . . . . . . . . . . . . . 415

L. sejunctum $J$. Thompson sp. nov. . . . . . . . . . . . . . . . . . . . 407

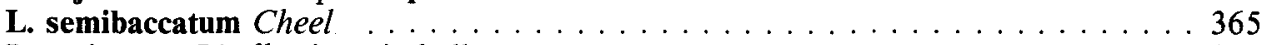

L. sericatum Lindley in Mitchell . . . . . . . . . . . . . . . . . . . . . . 383

L. sericeum Labill. . . . . . . . . . . . . . . . . . . . . . . . . . . . . . . 361

L. speciosum Schauer in Walp. . . . . . . . . . . . . . . . . . . . 357

L. spectabile $J$. Thompson sp. nov. . . . . . . . . . . . . . . . . . 431

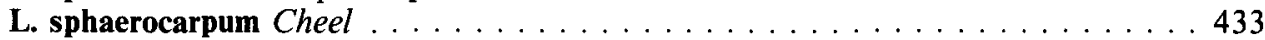

L. spinescens Endl. in Endl. et al. . . . . . . . . . . . . . . . . . . . . . . . 348

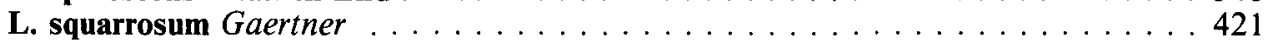

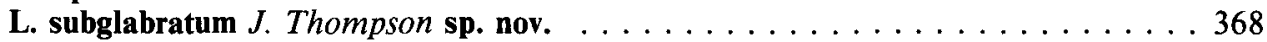

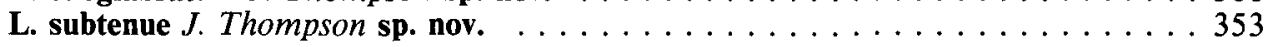

L. thompsonii $J$. Thompson sp. nov. . . . . . . . . . . . . . . . . . . 429

L. trinervium (Smith) J. Thompson comb. nov. . . . . . . . . . . . . . . . . . 366

L. turbinatum $J$. Thompson sp. nov. . . . . . . . . . . . . . . . . . . . 437

L. variabile $J$. Thompson sp. nov. . . . . . . . . . . . . . . . . . . . 403

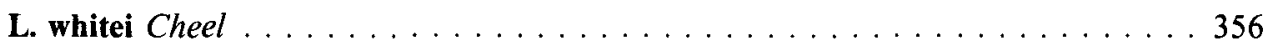

L. wooroonooran Bailey in Bailey \& A. Meston . . . . . . . . . . . . . . . 392

Manuscript received 13 January 1987

Manuscript accepted 18 May 1989 


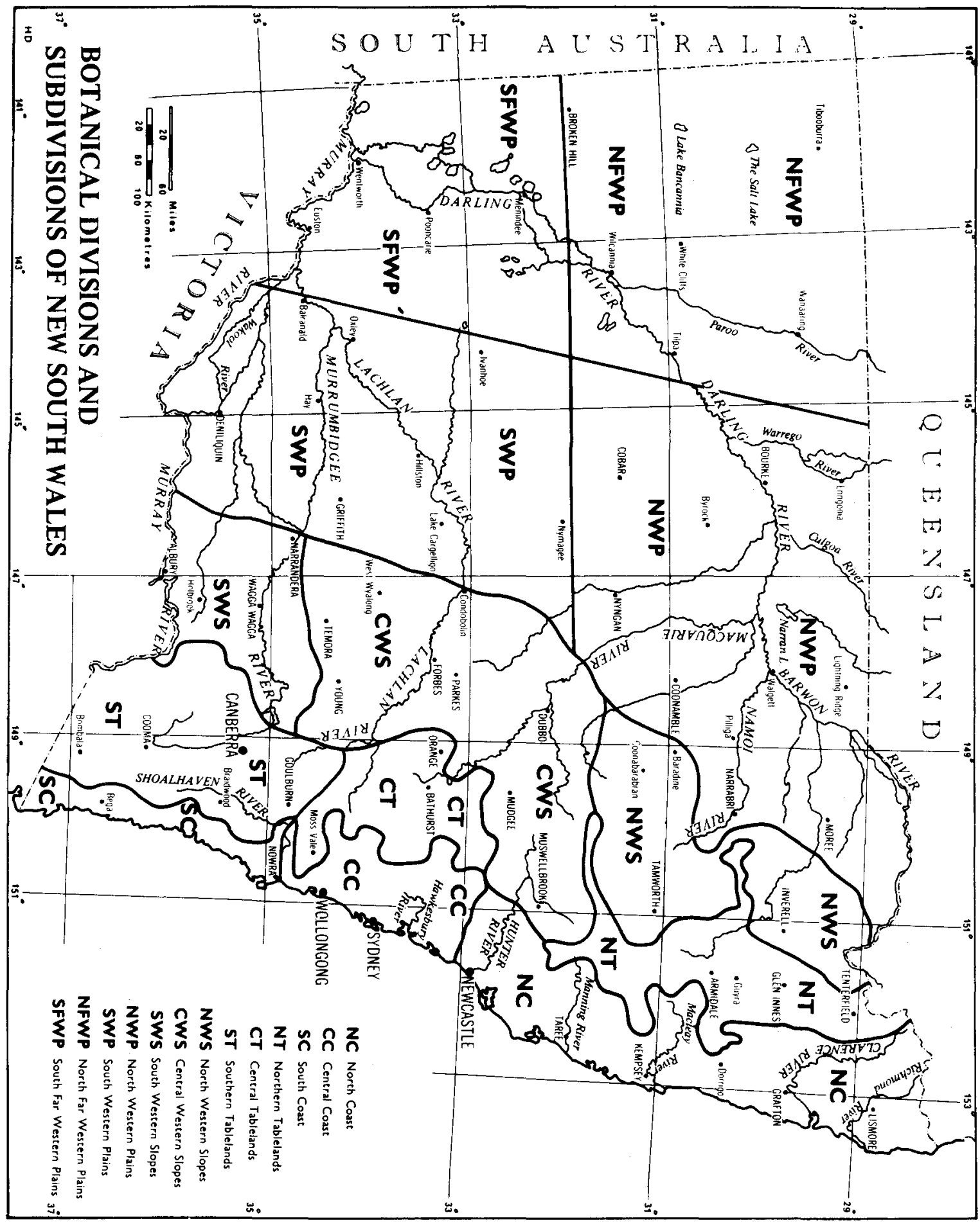

For explanation and description of the Botanical Divisions and Subdivisions of New South Wales see R.H. Anderson (1961) Introduction. Contr. New South Wales Natl Herb., Flora New South Wales Nos. 1-18: 1-15. 